\title{
THERMAL EVOLUTION OF SEDIMENTARY BASINS IN ALASKA
}

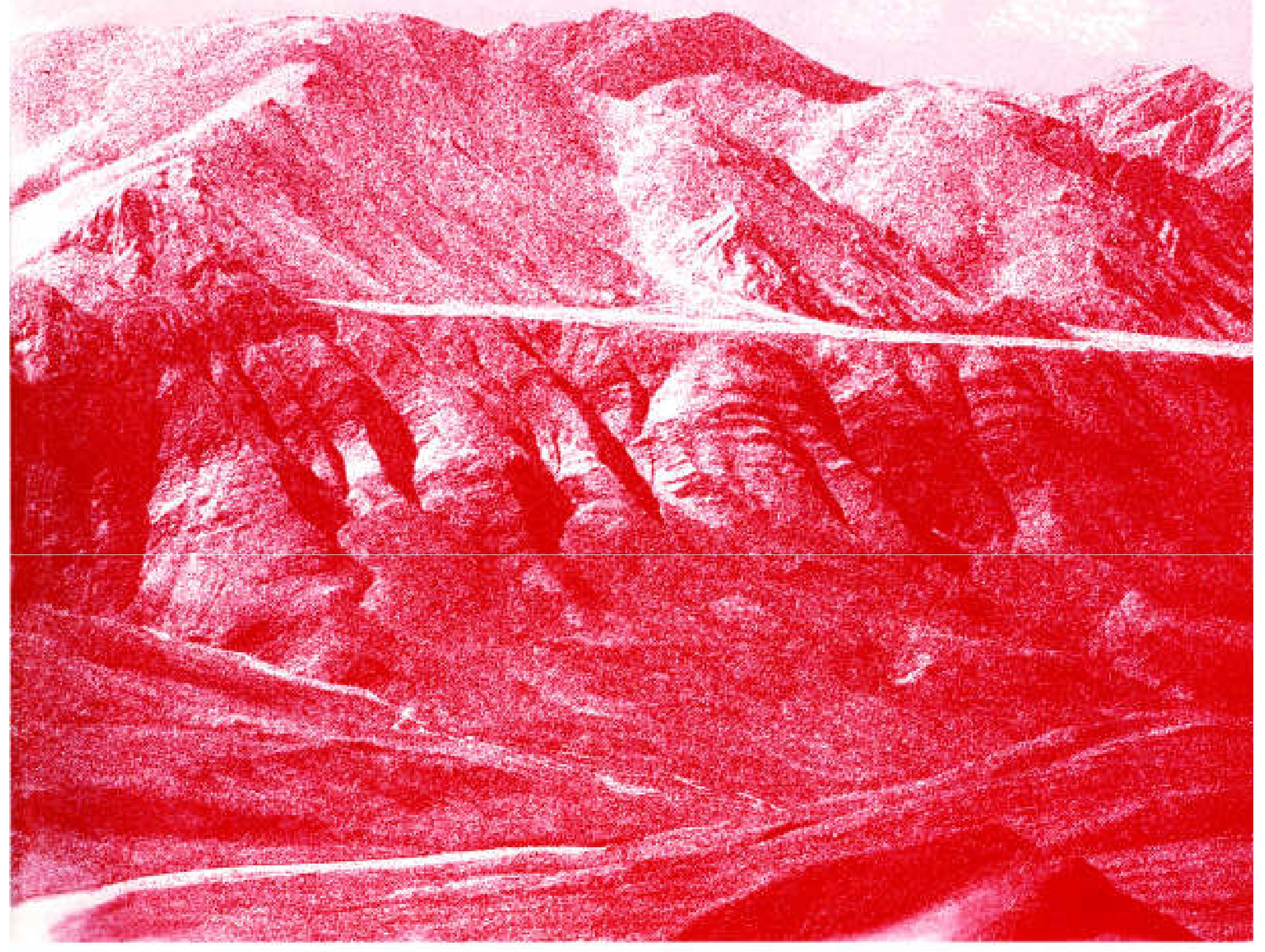

U.S. GEOLOGICAL SURVEY BULLETIN 2142 


\section{THERMAL EVOLUTION OF SEDIMENTARY BASINS IN ALASKA}

Mark J. Johnsson and David G. Howell, Editors

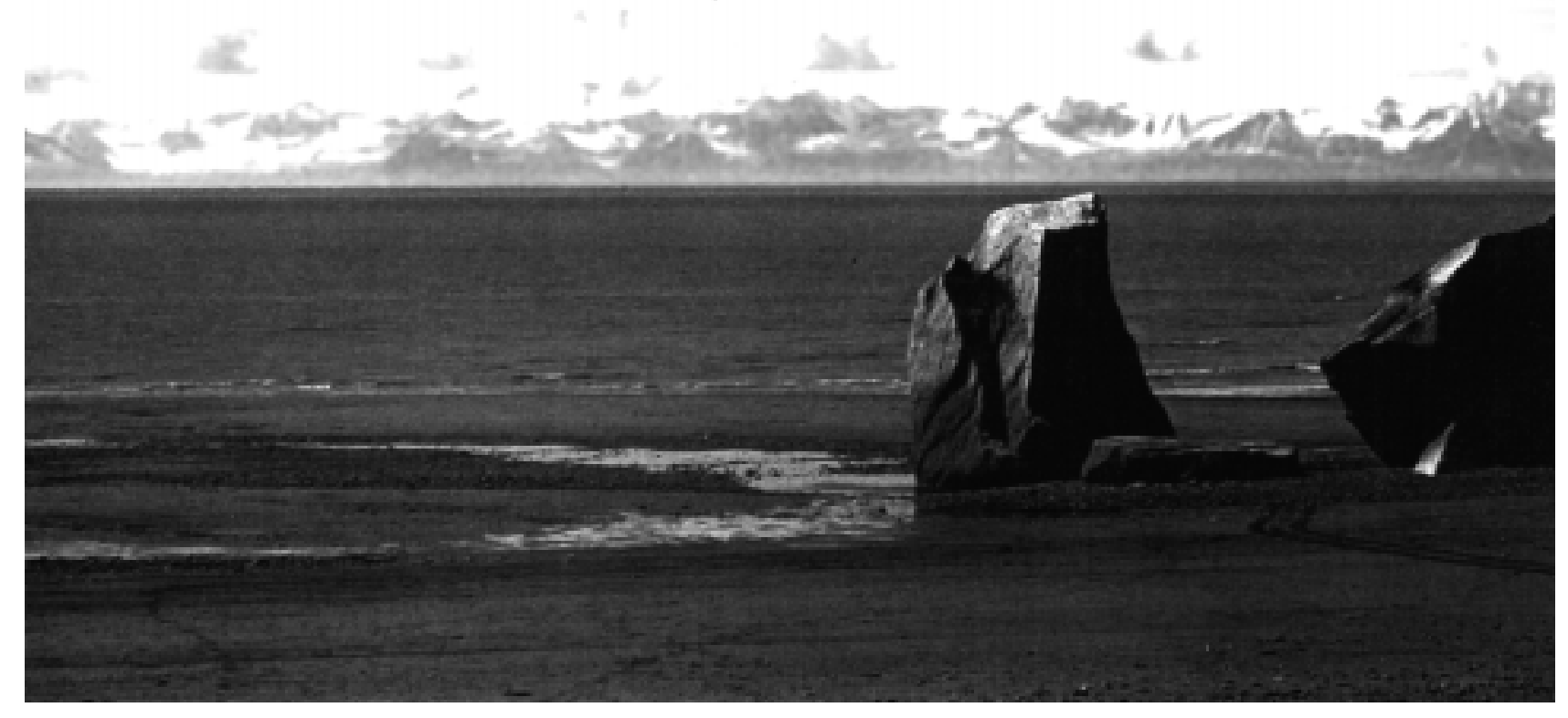

U.S. GEOLOGICAL SURVEY BULLETIN 2142

UNITED STATES GOVERNMENT PRINTING OFFICE, WASHINGTON: 1996 


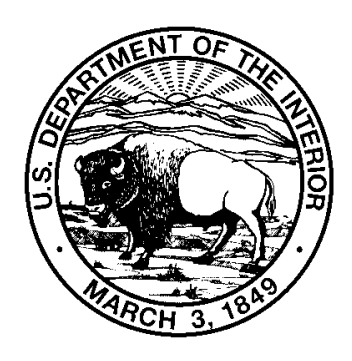

\title{
U.S. DEPARTMENT OF THE INTERIOR
}

\author{
BRUCE BABBITT, Secretary
}

\author{
U.S. GEOLOGICAL SURVEY
}

\section{Gordon P. Eaton, Director}

\author{
For sale by \\ U.S. Geological Survey, Map Distribution \\ Box 25286, MS 306, Federal Center \\ Denver, CO 80225
}

Any use of trade, product, or firm names in this publication is for descriptive purposes only and does not imply endorsement by the U.S. Government.

Text and illustrations edited for conformance to U.S. Geological Survey standards by James W. Hendley II Cover and title page created by J.F. Vigil and David G. Howell

Library of Congress Cataloging-in-Publication Data

Thermal evolution of sedimentary basins in Alaska / Mark J. Johnsson and David G. Howell, editors.

p. $\quad$ cm. -- (U.S. Geological Survey bulletin ; 2142) Includes bibliographical references.

Supt. of Docs. no. : I 19.3:2142

1. Sedimentary basins--Alaska. 2. Terrestrial heat flow--Alaska.

I. Johnsson, Mark J. II. Howell, D. G. III. Series.

QE75.B9 no. 2142

[QE571]

557.3 s--dc20

[551.1'4]

Cover-View along the Dalton Highway near Atigun Gorge looking southeast at the northern flank of the Brooks Range, note the raised terrace evincing youthful exhumation.

Title page-View looking westward across the Cook Inlet basin. The snow-capped mountains in the background are the Alaska Range, and the high peak on the left is Lliamna Volcano. Boulders in foreground are glacial erratics. 


\section{PREFACE}

U.S. Geological Survey geologists, together with colleagues from many other institutions, have undertaken tectonic and thermal studies in sedimentary basins of Alaska for the past two decades. In early 1990, the U.S. Geological Survey began a project to compile and assemble thermal-maturity data collected during these studies. Areas of limited sample coverage were enhanced by gathering data from the literature, by additional sampling and analysis, and by soliciting samples from individuals and industry groups working in Alaska. The resulting database of nearly 10,000 vitrinite-reflectance and conodont-color-alteration index determinations (Johnsson and others, 1992) was used to compile a thermalmaturity map of Alaska (pl. 1) and an interpretive summary of thermal-maturity patterns across the state (Johnsson and others, 1993).

It was clear, however, that additional information could be extracted from these data-thermogeochronologic, fluid inclusion, and isotopic techniques can supplement thermal maturity data. By combining such additional information with thermal-maturity data, we are better able to constrain tectonic and petroleum generation scenarios. Accordingly, we approached scientists conducting various thermal and uplift studies in Alaska and solicited contributions to a volume in which these techniques are explored. The goal was to provide a fairly detailed examination of several key types of sedimentary basins in Alaska - a classic foreland basin (Colville basin/North Slope), a forearc/backarc basin complex (Alaska Peninsula), and a tectonically dismembered basin (Kandik basin), such as is common throughout the tectonic collage of Alaska. This volume is the result of that effort.

The first paper in this volume, by Johnsson and Howell, is an overview of thermal-maturity patterns across the state. The remainder of the volume consists of a series of papers exploring the Alaska Peninsula, Colville basin, and Kandik basin in more detail. The first such paper, by Molenaar, explores the thermal-maturity patterns revealed from the assembled data on the Alaska Peninsula. The Alaska Peninsula is made up of the landward portions of backarc and forearc basins, as well as the Aleutian Arc itself. The thermal-maturity patterns reveal moderate uplift of basin sediments, notwithstanding that these sediments are deposited in currently active sedimentary basins. Younger rocks exposed on the southwestern portion of the peninsula are at higher thermal maturity than older rocks to the northeast, perhaps reflecting a higher geothermal gradient to the southwest.

The next two papers explore thermal and uplift relations within the Colville basin. The first, by Deming and others, explores modern heat-flow data from the basin by examining present geothermal gradients in light of thermal conductivity measurements from drill core and well cuttings. Both heat-flow and geothermal gradients increase systematically from south to north. At the same time, east-west variations in both parameters correlate with topographic basement highs, suggesting basement-controlled ground-water convection. These patterns of ground-water movement may have been important in determining the thermal regime within the Colville basin, and may have played a role in hydrocarbon migration as well. The second paper, by O'Sullivan, makes use of apatite fission-track data to constrain the uplift history of the Colville basin. Maximum burial temperatures in the southern part of the basin appear to have been reached in the Late Cretaceous to early Paleocene and were followed by periods of uplift in the Paleocene and late Oligocene. The later uplift event appears to be manifested in the northern part of the basin as a cooling event, but there is no evidence for erosion of the sedimentary section at that time.

The Kandik region of east-central Alaska represents a complex collisional basin fragment. The thermal, uplift, and fluid-migration history of the region is explored in the following two papers. The paper by Underwood and others presents a detailed examination of the thermal maturity of this tectonically complex region by using vitrinite-reflectance and illitecrystallinity data. These data constrain a model for tectonic burial beneath a thrust nappe and demonstrate the allochthoneity of distinct tectonostratigraphic terranes in east-central Alaska. The final paper, by Shelton and others, uses fluid-inclusion and isotopic data to further demonstrate the allochthoneity and distinct histories of these tectonostratigraphic terranes. Further, these data constrain the source of diagenetic fluids in the region and, by providing timing constraints on pressure estimates, provide evidence that burial, uplift, and erosion all occurred in a short time interval of approximately 15 million years.

These six papers present only a cursory overview of the potential of thermal- maturity studies in Alaska. Nevertheless, they do demonstrate the wealth of information that can be gleaned by applying a variety of techniques to specific problems. Further, they cover most of the important categories of sedimentary basins in Alaska and hopefully will provide departure points for future work in Alaska and elsewhere.

\section{REFERENCES CITED}

Johnsson, M.J., Howell, D.G., and Bird, K.J., 1993, Thermal maturity patterns in Alaska: Implications to tectonic evolution and hydrocarbon potential: American Association of Petroleum Geologists Bulletin, v. 77, p. 1874-1903.

Johnsson, M.J., Pawlewicz, M.J., Harris, A.G., and Valin, Z.C., 1992, Vitrinite reflectance and conodont color alteration index data from Alaska: Data to accompany the thermal maturity map of Alaska: U.S. Geological Survey Open-File Report 92-409, 3 diskettes. 


\section{ACKNOWLEDGMENTS}

We wish to thank all who have contributed to this volume, including authors, reviewers, and the editorial staff at the Branch of Western Technical Reports. Special thanks to James W. Hendley II, who oversaw production of this volume. Charles Barker, Robert Bauer, Kenneth Bird, Dwight Bradley, David Deming, Steve Ingebritsen, Barry Kohn, Leslie Magoon, John Murphey, and Paul Spry provided timely and thorough reviews; without their cooperation this volume would not have been possible. Kenneth Bird and Leslie Magoon have been instrumental in studies of thermal maturity in Alaska for nearly two decades, and their enthusiasm generated the impetus for this volume. Finally, Zenon Valin contributed mightily throughout this project, not only in the extraction and compilation of data, but also in aiding the general organization of the volume. Many thanks to all. 


\section{CONTENTS}

Thermal maturity of sedimentary basins in Alaska-An overview

By Mark J. Johnsson and David G. Howell --- A

Thermal maturity patterns and geothermal gradients on the Alaska

Peninsula

By Cornelius M. Molenaar --------o 11

Heat Flow and Subsurface Temperature, North Slope of Alaska

By David Deming, John H. Sass, and Arthur H. Lachenbruch ------------- 21

Late Mesozoic and Cenozoic thermo-tectonic evolution of the North

Slope foreland basin, Alaska

By Paul B. O'Sullivan

Thermo-tectonic evolution of suspect terranes in the Kandik Region of east-central Alaska

By Michael B. Underwood, David G. Howell, Mark J. Johnsson, and Mark J.

Pawlewicz

Stable isotopic and fluid inclusion studies of hydrothermal quartz and calcite veins from the Kandik thrust belt of east-central AlaskaImplications for thermo-tectonic history and terrane analysis

By Kevin L. Shelton, Michael B. Underwood, Isac B. Burstein, G. Ted

Heussler, and David G. Howell 


\title{
THERMAL EVOLUTION OF SEDIMENTARY BASINS IN ALASKA
}

\author{
U.S. Geological Survey Bulletin 2142
}

\section{Thermal Maturity of Sedimentary Basins in Alaska- An Overview}

\author{
By Mark J. Johnsson ${ }^{1}$ and David G. Howell ${ }^{2}$
}

\section{CONTENTS}

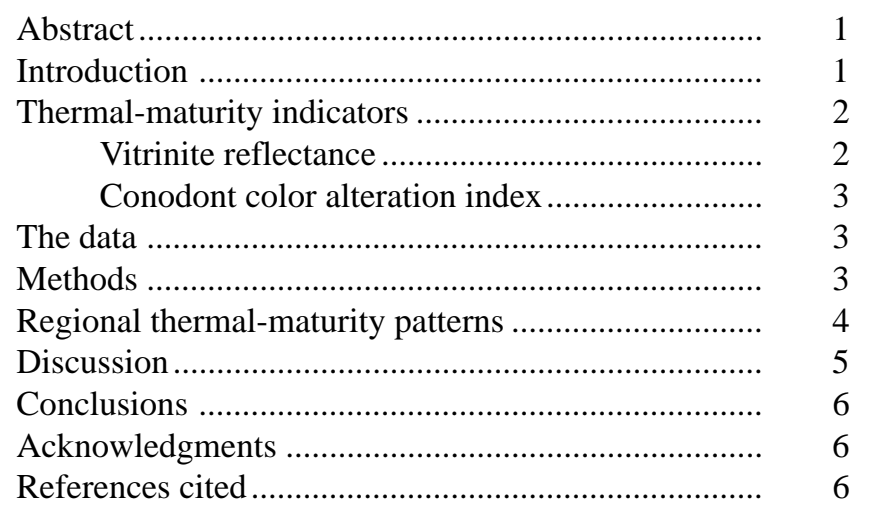

\begin{abstract}
The complex tectonic collage of Alaska is reflected in the conjunction of rocks of widely varying thermal maturity. Indicators of the level of thermal maturity of rocks exposed at the surface, such as vitrinite reflectance and conodont color alteration index, can help constrain the tectonic evolution of such complex regions and, when combined with petrographic, modern heat flow, thermogeochronologic, and isotopic data, allow for the detailed evaluation of a region's burial and uplift history. We have collected and assembled nearly 10,000 vitrinite-reflectance and conodont-color-alteration index val-
\end{abstract}

${ }^{1}$ Department of Geology, Bryn Mawr College, Bryn Mawr, PA 19010. ${ }^{2}$ U.S. Geological Survey, 345 Middlefield Road, Mail Stop 902, Menlo Park, California 94025-3591.

Manuscript approved for publication June 13, 1995. ues from the literature, previous U.S. Geological Survey investigations, and our own studies in Alaska. This database allows for the first synthesis of thermal maturity on a broadly regional scale.

Post-accretionary sedimentary basins in Alaska show wide variability in terms of thermal maturity. The Tertiary interior basins, as well as some of the forearc and backarc basins associated with the Aleutian Arc, are presently at their greatest depth of burial, with immature rocks exposed at the surface. Other basins, such as some backarc basins on the Alaska Peninsula, show higher thermal maturities, indicating modest uplift, perhaps in conjunction with higher geothermal gradients related to the arc itself. Cretaceous "flysch" basins, such as the Yukon-Koyukuk basin, are at much higher thermal maturity, reflecting great amounts of uplift perhaps associated with compressional regimes generated through terrane accretion. Many sedimentary basins in Alaska, such as the Yukon-Koyukuk and Colville basins, show higher thermal maturity at basin margins, perhaps reflecting greater uplift of the margins in response to isostatic unloading, owing to erosion of the hinterland adjacent to the basin or to compressional stresses adjacent to basin margins.

\section{INTRODUCTION}

Thermal maturity, a measure of the level of diagenetic alteration of organic matter in sedimentary rocks, provides a means of ascertaining the relative and, ideally, the absolute maximum temperatures to which sedimentary rocks have been exposed. Although various indicators of the level of thermal maturation (vitrinite reflectance, thermal-alteration index, conodont color alteration index, Rock-Eval pyrolysis) respond somewhat differently to time and temperature (Hood and others, 1975; Héroux and others, 1979), all appear to record the maximum temperature to which rocks have been exposed and are not susceptible to retrograde effects. In the absence of igneous heat sources, diagenetic temperatures are primarily a reflection of burial heating. The thermal maturity of rocks at 
the surface can thus be used to infer relative exhumation (and, by inference, uplift) subsequent to maximum burial. Thermal-maturity data have been used for many years to evaluate past burial depths and subsequent amounts of uplift and exhumation on a local or basinwide scale, but only recently have geologists begun broadly regional studies of thermal maturity. Thermal-maturity data are ideally suited to constrain problems of differential uplift on a regional scale and may allow for the evaluation of broad structural patterns not readily apparent by other means.

The complex tectonic makeup of Alaska, which is characterized by a collage of allochthonous terranes (Coney and others, 1980; Jones and others, 1987; Plafker, 1990), makes it an ideal locality to apply thermal-maturity data to help constrain basin evolution and regional tectonism. Sedimentary rocks in Alaska are found in a wide variety of tectonic settings, ranging from foreland, backarc, forearc, and post-orogenic basins to a variety of allochthonous or highly deformed sedimentary accumulations, such as accretionary-prism complexes, complex collisionally deformed basins, and tectonically displaced basin fragments. Because regional stratigraphic correlation among sedimentary units often is difficult or impossible, thermal-maturity data provide a useful means of evaluating basin structure and deformation.

\section{THERMAL-MATURITY INDICATORS}

Given the diversity of materials and techniques employed in assessing thermal maturity, establishing correlations between various thermal-maturity indicators can be difficult (Hood and others, 1975; Héroux and others, 1979). For this reason, we have restricted our assessment of the thermal maturity of sedimentary rocks in Alaska to vitrinite-reflectance and conodont-color-alteration-index data, which are by far the most common thermal-maturity data available from Alaska. Conodont color alteration index and vitrinite reflectance have been empirically correlated through both field (Epstein and others, 1977) and laboratory studies (Rejebian and others, 1987. See table 1).

\section{VITRINITE REFLECTANCE}

Vitrinite, one of several types of organic matter commonly found disseminated in clastic sedimentary rocks, represents the remains of woody plant material and can be found in post-Silurian organic-rich rocks of terrestrial provenance. During burial diagenesis, loss of volatile components and graphitization of carbon results in an increase in the optical reflectivity of vitrinite. Reflectivity increases regularly proportional to temperature, is not influenced by pressure or chemical reactions with most diagenetic fluids, and is not susceptible to retrograde alteration (Bostick, 1979). Accordingly, it has become the most widely used measure of ther-
Table 1. Correlation of thermal-maturity indicators.

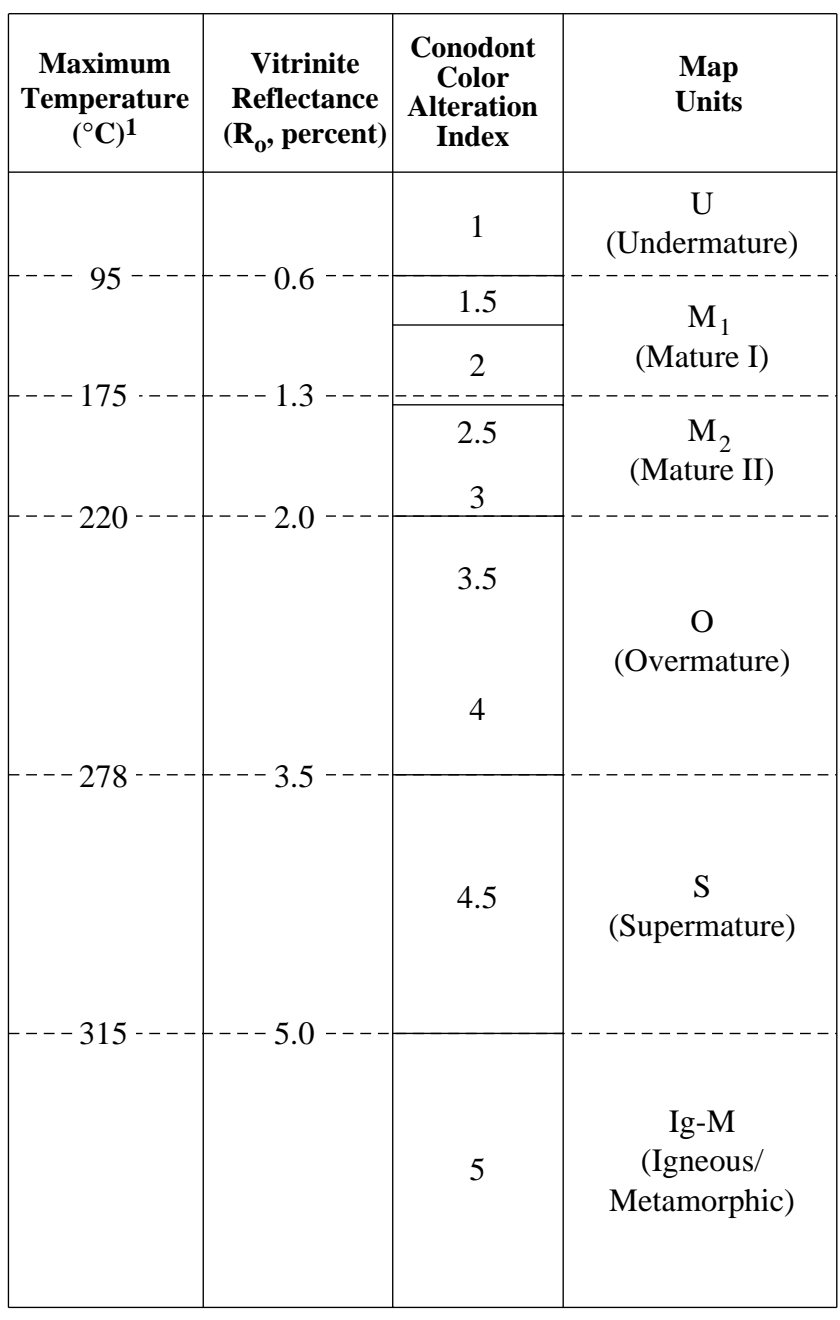

${ }^{1}$ Temperature $\left({ }^{\circ} \mathrm{C}\right)=104\left(\ln \mathrm{R}_{\mathrm{o}}\right)+148 \quad($ Barker, 1988$)$.

mal maturity in sedimentary rocks. Recent kinetic models (Burnham and Sweeney, 1989; Sweeney and Burnham, 1990) and field studies where the duration of heating is well constrained (Barker, 1983; 1991) suggest that, for heating periods greater than $\sim 10^{4}$ years, maximum temperature and not the duration of heating largely determines the level of reflectance. Accordingly, vitrinite reflectance may be used with caution to establish absolute maximum paleotemperatures. Many workers have proposed equations relating temperature (T) and vitrinite reflectance $\left(\mathrm{R}_{\mathrm{o}}\right)$ (Bostick, 1979; Price, 1983; Barker and Pawlewicz, 1986; Barker, 1988). We prefer the correlation of Barker (1988):

$$
\mathrm{T}\left({ }^{\circ} \mathrm{C}\right)=104\left(\ln \mathrm{R}_{\mathrm{o}}\right)+148
$$

as it most closely matches the results predicted by kinetic models (Burnham and Sweeney, 1989; Sweeney and Burnham, 1990; Suzuki and others, 1993). 


\section{CONODONT COLOR ALTERATION INDEX}

Conodonts are tooth-like microfossils of an extinct group of primitive chordates, commonly 0.1 to $1 \mathrm{~mm}$ in size, that occur in marine rocks of Cambrian through Triassic age (Epstein and others, 1977). They are common in carbonate and poorly indurated clastic rocks, but their abundance generally varies inversely with sedimentation rate. Conodonts grew throughout the life of the animal by periodic addition of apatite layers separated by layers of organic matter. During burial diagenesis, the organic matter sealed between transparent apatite lamellae undergoes carbonization, producing visible color changes from pale yellow through amber, light brown, dark brown, and black in the range of $50^{\circ}$ to $300^{\circ} \mathrm{C}$ (Epstein and others, 1977). Above $300^{\circ} \mathrm{C}$, conodonts change from black through gray, opaque white, and finally to crystal clear as a result of carbon loss, release of water of crystallization, and recrystallization. All of these color changes have been observed in natural samples and reproduced and calibrated by pyrolysis experiments in the laboratory (Epstein and others, 1977; Rejebian and others, 1987). The conodont color alteration index (CAI) is the quantification of these color changes through the use of established standards.

\section{THE DATA}

Since 1976, the U.S. Geological Survey has been compiling a database of thermal-maturity data collected during various geologic investigations in Alaska. We combined vitrinite-reflectance data from that database, from the literature ${ }^{3}$ and from unpublished industry reports provided to the Alaska Division of Geological and Geophysical Surveys with CAI data collected and compiled by Anita G. Harris (U.S. Geological Survey) to produce a database of thermal-maturity data from sedimentary rocks in Alaska. The spatial distribution of these data was improved through our own field efforts and through samples obtained from industry, academic, and government colleagues.

Our database (Johnsson and others, 1992) consists of 3,716 vitrinite-reflectance determinations from 2,123 outcrop localities and 1,474 CAI determinations from 1,306 outcrop localities (Fig. 1). In addition to the outcrop data, we have assembled 4,482 vitrinite-reflectance determinations from 217 wells (Fig. 1). The bulk of these wells are in the Colville and

${ }^{3}$ (Rao, 1980; Brosgé and others, 1981; Magoon and Claypool, 1981; Fisher, 1982; Harris and others, 1983; Rao and Smith, 1983; Bruns and others, 1985; Merritt, 1985a, b; Belowich, 1986; Cameron and others, 1986; Merritt, 1986a, b; Merritt and McGee, 1986; Smith and Rao, 1986; Gautier and others, 1987; Harris and others, 1987; Magoon and others, 1987; Stanley, 1987; Bayliss and Magoon, 1988; Claypool and Magoon, 1988; Magoon and Bird, 1988; Magoon and Claypool, 1988; Stanley, 1988; Robinson, 1989; Underwood and others, 1989; Laughland and others, 1990; Merritt, 1990; Reifenstuhl, 1990; Stanley and others, 1990; Howell, Bird, and others, 1992; Howell, Johnsson, and others, 1992).
Cook Inlet basins, where the vast majority of drilling activity in Alaska has taken place.

We combined our organic thermal-maturity data with petrologic data as portrayed on the metamorphic facies map of Alaska by Dusel-Bacon (1991). In general, a good correlation exists at lower metamorphic grades between organic and petrologic indicators. Thus, the thermal maturity map (pl. 1) and metamorphic facies map (Dusel-Bacon, 1991) of Alaska together portray maximum paleotemperatures, ranging from surface to igneous conditions, of rocks exposed at the surface in Alaska.

\section{METHODS}

Because our vitrinite-reflectance data have been assembled from diverse sources, analytical methods and standards vary. As shown by Claypool and Magoon (1985), relative variability of vitrinite-reflectance measurements between laboratories is about \pm 15 percent. Nevertheless, the general consistency of our results indicates that the underlying thermal-maturity "signal" rises above the background "noise" introduced by nonstandardized techniques, at least when the data are considered at a regional scale.

Of the total data set, vitrinite-reflectance determinations from 661 samples were performed by Mark J. Pawlewicz (U.S. Geological Survey). For these determinations, samples were ground to less than 48 mesh, and the dispersed organic matter was concentrated as described by Barker (1982). Concentrates were mounted on glass slides following methods of Baskin (1979) and polished using methods of Pawlewicz (1987). Vitrinite-reflectance was measured under vertical illumination on a Zeiss Universal microscope fitted with an MPM-01 microphotometric system. Reflectance was measured for up to 50 vitrinite particles per sample. Subsequent data analysis was based on the mean of these values, once possible contamination or multiple populations had been accounted for. Further discussion of vitrinite reflectance procedures is given in Johnsson and others (1992).

All CAI determinations were performed by Anita G. Harris (U.S. Geological Survey). Preparation techniques followed those of Harris and Sweet (1989). Conodonts from carbonate rocks were released by acid dissolution (6-7 percent acetic acid solution for limestones and metalimestones, 4-5 percent formic acid solution for dolostones and metadolostones). Conodonts were released from chert using a 4-5 percent hydrofluoric acid solution and the methods of Orchard (1987). Conodonts were concentrated from the insoluble residue using heavy liquid and magnetic separation techniques (Dow, 1965; Stone, 1987) and were hand picked for final analysis. CAI values were determined following the procedures given in Epstein and others (1977) and Rejebian and others (1987). A set of CAI standards was used for indexing - each CAI value is represented by 10 to 30 naturally and experimentally altered, morphologically diverse speci- 
mens. Details of analytical procedures are outlined in Johnsson and others (1992).

\section{REGIONAL THERMAL-MATURITY PATTERNS}

Thermal-maturity data from outcrop localities and from wells (extrapolated to the surface) were used to produce a map showing the thermal maturity of rocks exposed at the surface (pl. 1). We defined six thermal maturity map units (table 1), identified on the basis of hydrocarbon maturation regimes (Poole and Claypool, 1984)-undermature $\left(\mathrm{R}_{0} \leq 0.6\right.$, $\mathrm{CAI}=1)$, mature I $\left(0.6<\mathrm{R}_{0} \leq 1.3,1<\mathrm{CAI} \leq 2\right)$, mature II $\left(1.3<\mathrm{R}_{\mathrm{o}} \leq 2.0,2<\mathrm{CAI} \leq 3\right)$, overmature $\left(2.0<\mathrm{R}_{\mathrm{o}} \leq 3.5,3<\mathrm{CAI} \leq 4\right)$, supermature $\left(3.5<\mathrm{R}_{\mathrm{o}} \leq 5.0,4<\mathrm{CAI} \leq 4.5\right)$, and igneous-metamorphic $\left(\mathrm{R}_{\mathrm{o}}>5.0, \mathrm{CAI}>4.5\right)$. The last unit includes plutonic, volcanic, and metamorphic rocks identified largely on the basis of previously published maps (Beikman, 1980; DuselBacon, 1991) but in some cases refined by the thermal maturity data. The supermature unit was further constrained, in part, by the laumontite-prehnite-pumpellyite facies of DuselBacon (1991). Preliminary interpretations of the thermal- maturity patterns revealed by this map, particularly in the Colville, Cook Inlet, and Kandik basins (pl. 1), are discussed by Johnsson and others (1993).

The Tertiary basins of interior Alaska (for example, Copper River, Yukon Flats, Susitna, Holitna, Minchumina, Bethel, and Nenana basins) are marked by very low thermal maturity at the surface; samples from near the tops of the few wells penetrating these basins are generally undermature. This observation is consistent with the interpretation that these basins are at their maximum burial depth and have experienced little or no uplift, a conclusion generally supported on the basis of stratigraphy as well (Kirschner, in press). Because most of these basins contain less than $2 \mathrm{~km}$ of sediments (Kirschner, 1988; Kirschner, in press), thermal maturity at depth is unlikely to be appreciably greater.

Forearc and backarc basins flanking the Aleutian Arc also are of fairly low thermal maturity at the surface. Thermal-maturity values extrapolated to the sea floor from data from offshore wells in the Tertiary Aleutian forearc (ShelikofShumagin-Sanak basin) and backarc basins (Bristol Bay-St. George basin) indicate undermature to mature conditions at the surface, suggesting that the basins are at or near maximum burial depth. Unlike the interior basins, however, sediments in these basins reach thicknesses of $5 \mathrm{~km}$ or more

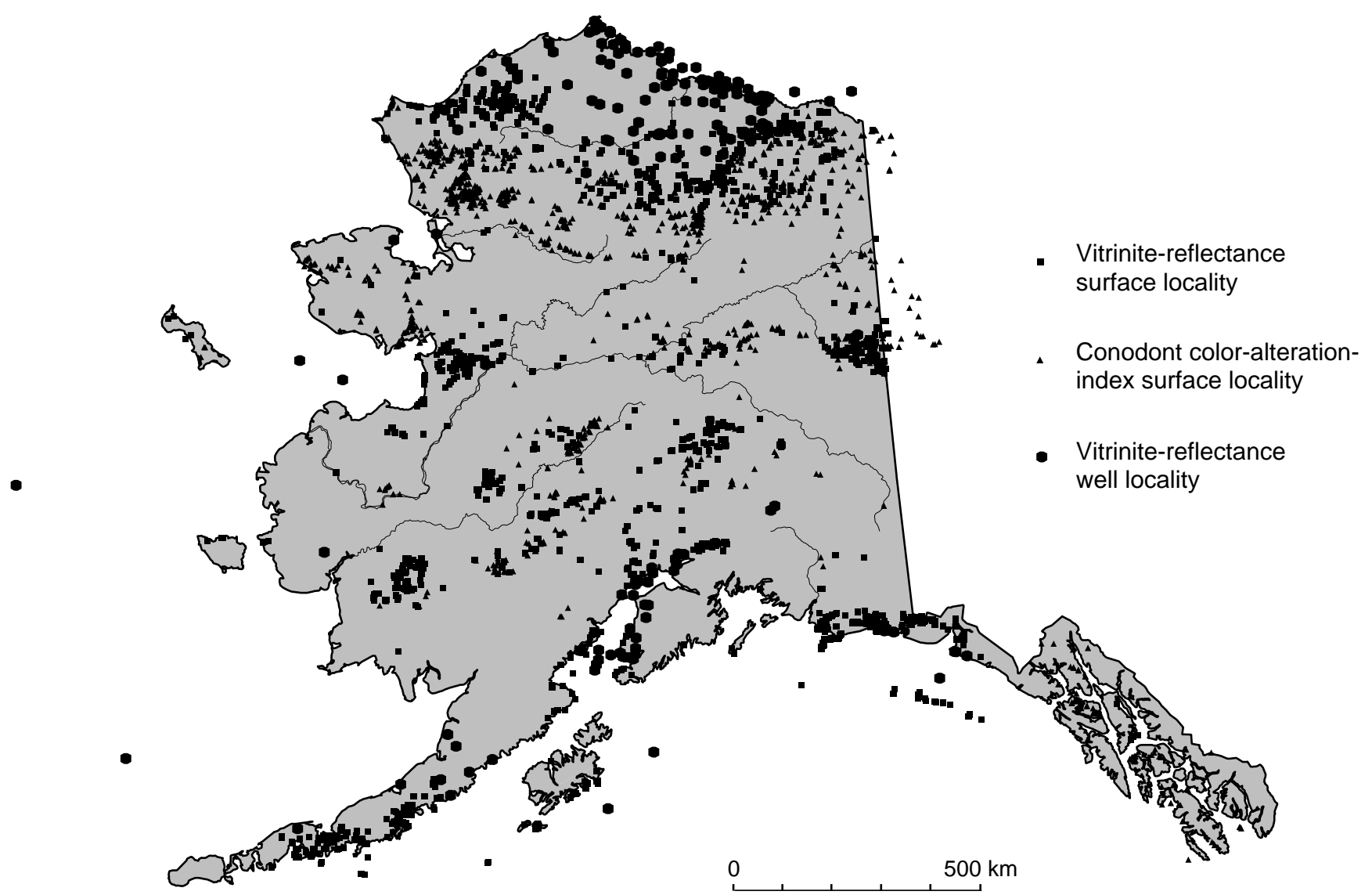

Figure 1. Index map of Alaska showing locations of sample stations. Most localities are represented by multiple samples. Offshore "surface" localities are from dredge hauls. 
(Kirschner, 1988; Kirschner, in press), and thermal maturity at depth is appreciably greater (up to overmature), as evidenced by well data (see Johnsson and others, 1992). The Cook Inlet basin, part of the Aleutian forearc, exposes undermature rocks at the surface, but numerous wells penetrate mature I and mature II rocks at depths of as much as 7 $\mathrm{km}$. The situation is somewhat more complicated on the Alaska Peninsula, which is part of the Aleutian Arc itself. Regions of somewhat higher thermal maturity (mostly mature II) occur in forearc and backarc sediments of Tertiary age in the southern part of the Alaska Peninsula, whereas Jurassic and Cretaceous sediments of the northern part of the peninsula are generally less mature (mostly mature I), except in the vicinity of large plutons or active volcanism (Molenaar, this volume; pl. 1).

The Colville basin, on the North Slope, is the best example of a foreland basin in Alaska. The North Slope shows a southward increase in the thermal maturity of rocks exposed at the surface (pl. 1). This southward increase in thermal maturity, which corresponds to proximity to the Brooks Range orogen, indicates progressively greater uplift and exhumation of foreland basin sediments toward the orogen (Howell, Bird, and others, 1992).

Many sedimentary rocks in Alaska are found not in welldefined sedimentary basins but rather in broadly deformed or dismembered basin fragments. The Jurassic and Cretaceous "flysch" of western Alaska (Yukon-Koyukuk basin, Kuskokwim flysch belt) is an example of a deformed series of sedimentary basins whose tectonic settings are poorly constrained. A varied thermal-maturity pattern indicates a complex pattern of uplift and deformation that is not readily apparent from traditional mapping of stratigraphic and structural relations. The Yukon-Koyukuk basin shows a nearly concentric thermal-maturity pattern (pl. 1). This geometry suggests a pattern of greater uplift at basin margins. Other complex compressional basins, such as the Kandik "basin"-actually a fold and thrust belt contiguous with the Canadian Cordillera-in east-central Alaska, show thermal-maturity patterns that reflect large amounts of uplift, as well as anomalous emplacement of younger thermally mature rocks over older thermally immature rocks. Such relations are evidence of episodes of complex vertical movement or convective heat transfer by complex fluid-circulation patterns. Although the details of such movements are yet to be determined in many such basin fragments, ongoing work in the Kandik basin has used thermal maturity to constrain a complicated tectonic history (Underwood and others, 1989, 1992, this volume; Howell, Johnsson, and others, 1992; Johnsson and others, 1993; Shelton and others, this volume).

\section{DISCUSSION}

This study is the first comprehensive treatment of thermal-maturity patterns across Alaska. One previous study
(Daggett, 1987) did, however, explore vitrinite reflectance patterns in rocks of Cretaceous age over a vast region of southwest Alaska. Daggett (1987) identified three thermal provinces: (1) a southern zone (Alaska Peninsula, Cook Inlet basin) with low thermal maturity ( $\mathrm{R}_{\mathrm{o}}=0.3$ to 1.0 percent), (2) a central zone (Kuskokwim Group and lithologically similar rocks) of higher thermal maturity ( $\mathrm{R}_{0}=0.4$ to 2.0 percent), and (3) a northern zone (Yukon-Koyukuk basin) with the highest thermal maturity ( $R_{o}=0.4$ to 2.2 percent). He interpreted these provinces to represent three parts of a typical convergent margin - a forearc region (Alaska Peninsula, Cook Inlet basin), a magmatic arc (Kuskokwim flysch belt), and the "trailing edge of the arc" (Yukon-Koyukuk basin). Our data corroborate the patterns observed by Daggett (1987), but owing to the complex tectonic character of that portion of the state, we are hesitant to attribute the pattern to a simple, single convergent-margin setting. Although we agree that the Alaska Peninsula and Cook Inlet basins represent forearc basins, the Kuskokwim flysch belt lies well inland (northwestward) of the Cretaceous magmatic arc and more likely reflects continental-margin sediments that were deeply buried before being uplifted during terrane accretion in southwestern Alaska (Box, 1985; 1992; Box and Elder, 1992). Furthermore, the thermal-maturity patterns, when examined in detail, are more complicated than suggested by Daggett (1987). For example, the Yukon-Koyukuk basin exhibits a concentric pattern of thermal maturity values (pl. 1). The northeast-southwest axis of this pattern (pl. 1) is consistent with southeast-northwest compression, perhaps reflecting convergence of the North America and Eurasian Plates, as suggested by Patton and Tailleur (1977).

This pattern of higher surface thermal maturity at basin margins recurs throughout Alaska (for example, Colville, Yukon-Koyukuk, and Cook Inlet basins), despite the fact that in some of these basins there is good stratigraphic evidence to suggest that burial depths were greatest at basin centers. Perhaps differential uplift, concentrated at basin margins, commonly occurs either as a result of isostatic rebound as collisional orogens adjacent to margins are removed by erosion or through uplift and erosion as basins are compressed subsequent to their creation.

An independent means of ascertaining uplift, complementing the thermal-maturity data, are geochronologic data. Such data reflect the age at which the mineral under investigation started behaving as a closed system with respect to the radiogenic isotopes under consideration, generally as a result of cooling. O'Sullivan (this volume) provides apatite fission track data for the Colville basin and northern Brooks Range that indicate multiple phases of uplift in the region. His data indicate a more complicated uplift pattern for the Colville basin than is recorded in the vitrinite-reflectance data. The simple uplift model discussed above apparently is complicated by episodic regional uplift.

Deming and others (1992; this volume) showed that modern heat-flow and geothermal gradients in the Colville 
basin generally decrease from north to south and proposed a deep-ground-water circulation model, with recharge in the Brooks Range and discharge north of the Arctic coastline, to account for the pattern. The distribution of modern heat anomalies mirrors subsurface thermal-maturity patterns (Johnsson and others, 1993), suggesting that the patterns may be genetically linked. If so, thermal-maturity data can be used in conjunction with modern heat-flow data to constrain deep basin circulation patterns in the past. Complex thermal-maturity relations in the Kandik basin may similarly be related to ancient hydrothermal circulation (Shelton and others, this volume).

\section{CONCLUSIONS}

Thermal-maturity patterns in Alaska reflect the complex tectonic history of the region. Tectonostratigraphic terranes of diverse origin and history are juxtaposed, creating a pattern of sharply contrasting thermal maturities across the state. Sedimentary basins found on these terranes commonly exhibit higher surface thermal maturity at basin margins than at basin centers. This pattern suggests greater uplift at basin margins, possibly reflecting isostatic readjustments or compression resulting from terrane accretion. Thermal-maturity patterns may be used in conjunction with modern heat-flow data, information on fluid composition and circulation, and thermogeochronologic methods to constrain tectonic and thermal evolution of structurally complex regions, such as Alaska.

\section{ACKNOWLEDGMENTS}

We wish to extend our sincere thanks to all of those individuals and organizations who contributed data to this project. Special thanks are due Anita Harris, who contributed her entire database of CAI values, and to Shell Oil Company, British Petroleum, and Chevron Inc. for donations of vitrinitereflectance data from their files. Arlene Anderson, Steve Box, Harvey Cohen, Marti Miller, John Murphey, William W. Patton Jr., Rocky Reifenstuhl, and Richard G. Stanley contributed samples, from which Mark J. Pawlewicz produced several hundred vitrinite-reflectance determinations. Assistance in the field was provided by William Arendt, Thomas Brocculeri, Pascal Desegaulx, Nomane Fehri, Donald L. Gautier, Lu Huafu, Patrick McClung, Paul B. O’Sullivan, François Roure, Christopher J. Schenk, and Michael B. Underwood. Technical assistance with drafting, data entry, and GIS was provided by Brian S. Bennet, Todd T. Fitzgibbon, Christopher H. Hamilton, Patrick K. Showalter, Phyllis A. Swenson, Zenon C. Valin, Carl M. Wentworth Jr., and Florence L. Wong. Cynthia Dusel-Bacon made available early versions of her metamorphic facies map of Alaska and helped interpret inorganic indicators of low-grade metamorphism and regional geology. Kenneth J. Bird and Katryn Wiese com- mented on an earlier draft of this manuscript, improving its quality tremendously. Finally, Kenneth J. Bird and Leslie B. Magoon were instrumental in organizing thermal-maturity studies in Alaska over the past two decades, and it was largely at their suggestion that this project was undertaken.

\section{REFERENCES CITED}

Barker, C.E., 1982, A rapid method for concentrating sedimentary organic matter for vitrinite reflectance analysis: Journal of Sedimentary Petrology, v. 52, p. 663-664.

1983, Influence of time on metamorphism of sedimentary organic matter in liquid-dominated geothermal systems, western North America: Geology, v. 11, p. 384-388.

1988, Geothermics of petroleum systems: implications of the stabilization of kerogen thermal maturation after a geologically brief heating duration at peak temperature, in Magoon, L.B., ed., Petroleum systems of the United States: U.S. Geological Survey Bulletin 1870, p. 26-29.

1991, Implications for organic maturation studies of evidence for a geologically rapid increase and stabilization of vitrinite reflectance at peak temperature: Cerro Prieto geothermal system, Mexico: American Association of Petroleum Geologists Bulletin, v. 75, p. 1852-1863.

Barker, C.E., and Pawlewicz, M.J., 1986, The correlation of vitrinite reflectance with maximum paleotemperature in humic organic matter, in Buntebarth, G., and Stegena, L., eds., Paleogeothermics: New York, Springer-Verlag, p. 79-93.

Baskin, D.K., 1979, A method of preparing phytoclasts for vitrinite reflectance analysis: Journal of Sedimentary Petrology, v. 49, p. 633-635.

Bayliss, G.S., and Magoon, L.B., 1988, Organic facies and thermal maturity of sedimentary rocks in the National Petroleum Reserve in Alaska, in Gryc, G., ed., Geology and exploration of the National Petroleum Reserve in Alaska, 1974 to 1982: U.S. Geological Survey Professional Paper 1399, p. 489-518.

Beikman, H.M., 1980, Geologic map of Alaska: U.S. Geological Survey, 2 sheets, scale 1:2,500,000.

Belowich, M.A., 1986, Basinal trends in coal, petrographic, and elemental composition with applications toward seam correlation, Jarvis Creek Coal Field, Alaska, in Focus on Alaska's Coal '86, Proceedings of the conference held at Anchorage, Alaska, October 27-30, 1986: Fairbanks, Alaska, Mineral Industry Research Laboratory, p. 300-335.

Bostick, N.H., 1979, Microscopic measurement of the level of catagenesis of solid organic matter in sedimentary rocks to aid exploration for petroleum and to determine former burial temperatures-A review, in Scholle, P.A., and Schluger, P.R., eds., Aspects of diagenesis: Tulsa, Oklahoma, Society of Economic Paleontologists and Mineralogists Special Publication 26, p. $17-44$.

Box, S.E., 1985, Terrane analysis of the northern Bristol Bay region, southwestern Alaska, in Bartsch-Winkler, S., ed., The United States Geological Survey in Alaska: Accomplishments during 1984: U.S. Geological Survey Circular 967, p. 32-37.

1992, Evidence for basin-margin right-slip faulting during Kuskokwim Group deposition, southwestern Alaska [abs.]: Geological Society of America Abstracts with Programs, v. 24, p. 8-9. 
Box, S.E., and Elder, W.P., 1992, Depositional and biostratigraphic framework of the Upper Cretaceous Kuskokwim Group, southwestern Alaska, in Bradley, D.C., and Ford, A.B., eds., Geologic studies in Alaska by the U.S. Geological Survey, 1990: U.S. Geological Survey Bulletin 1999, p. 8-16.

Brosgé, W.P., Reiser, H.N., Dutro, J.T., Jr., and Detterman, R.L., 1981, Organic geochemical data for Mesozoic and Paleozoic shales, central and eastern Brooks Range, Alaska: U.S. Geological Survey Open-File Report 81-551, 17 p.

Bruns, T.R., von Huene, R., Curlotta, R.C., and Lewis, S.D., 1985, Summary geologic report for the Shumagin Outer Continental Shelf (OCS) planning area, Alaska: U.S. Geological Survey Open-File Report 85-32, 58 p.

Burnham, A.K., and Sweeney, J.J., 1989, A chemical kinetic model of vitrinite reflectance maturation and reflectance: Geochimica et Cosmochimica Acta, v. 53, p. 2649-2657.

Cameron, A.R., Norris, D.K., and Pratt, K.C., 1986, Rank and other compositional data on coals and carbonaceous shale of the Kayak formation, northern Yukon Territory, in Current research, part B: Geological Survey of Canada, p. 665-670.

Claypool, G.E., and Magoon, L.B., 1985, Comparison of oil-source rock correlation data for Alaskan North Slope: Techniques, results, and conclusions, in Magoon, L.B., and Claypool, G.E., eds., Alaska North Slope oil-rock correlation study: Tulsa, Oklahoma, American Association of Petroleum Geologists Studies in Geology 20, p. 49-81.

1988, Oil and gas source rocks in the National Petroleum Reserve in Alaska, in Gryc, G., ed., Geology and exploration of the National Petroleum Reserve in Alaska, 1974 to 1982: U.S. Geological Survey Professional Paper 1399, p. 451-481.

Coney, P.J., Jones, D.L., and Monger, J.W.H., 1980, Cordilleran suspect terranes: Nature, v. 288, p. 329-333.

Daggett, P.H., 1987, Late Cretaceous thermal regime of southern Alaska [abs.]: Geological Society of America Abstracts with Programs, v. 19, p. 634.

Deming, D., Sass, J.H., Lachenbruch, A.H., and De Rito, R.F., 1992, Heat flow and subsurface temperature as evidence for basinscale groundwater flow, North Slope of Alaska: Geological Society of America Bulletin, v. 104, p. 528-542.

Dow, V.E., 1965, Magnetic separation of conodonts, in Kummel, B., and Raup, D., eds., Handbook of paleontological techniques: San Francisco, W.H. Freeman, p. 263-267.

Dusel-Bacon, C., 1991, Metamorphic history of Alaska: U.S. Geological Survey Open File Report 91-556, 2 sheets, scale $1: 2,500,000$.

Epstein, A.G., Epstein, J.B., and Harris, L.D., 1977, Conodont color alteration-An index to organic metamorphism: U.S. Geological Survey Professional Paper 995, 27 p.

Fisher, M.A., 1982, Petroleum geology of Norton Basin, Alaska: American Association of Petroleum Geologists Bulletin, v. 66, p. 286-301.

Gautier, D.L., Bird, K.J., and Colten-Bradley, V.A., 1987, Relationship of clay mineralogy, thermal maturity, and geopressure in wells of the Point Thomson area, in Bird, K.J., and Magoon, L.B., eds., Petroleum geology of the northern part of the Arctic National Wildlife Refuge, northeastern Alaska: U.S. Geological Survey Bulletin 1778, p. 199-207.

Harris, A.G., Ellersieck, I.F., Mayfield, C.F., and Tailleur, I.L., 1983, Thermal maturation values (conodont color alteration indices) for Paleozoic and Triassic rocks, Chandler Lake, De Long Mountains, Howard Pass, Killik River, Misheguk Mountain, and Point Hope quadrangles, northwest Alaska, and subsurface NPRA: U.S. Geological Survey Open-File Report 83-505, $15 \mathrm{p}$.

Harris, A.G., Lane, H.R., Tailleur, I.L., and Ellersieck, I., 1987, Conodont thermal maturation patterns in Paleozoic and Triassic rocks, northern Alaska-Geologic and exploration implications, in Tailleur, I., and Weimer, P., eds., Alaskan North Slope Geology: Bakersfield, California, and Anchorage, Alaska, Pacific Section, Society of Economic Paleontologists and Mineralogists and the Alaska Geological Society, p. 181-191.

Harris, A.G., and Sweet, W.C., 1989, Mechanical and chemical techniques for separating microfossils from sediment and residue matrix, in Feldmann, R.M., Chapman, R.E., and Hannibal, J.T., eds., Paleotechniques: Paleontological Society Special Publication 4, p. 70-86.

Héroux, Y., Chagnon, A., and Bertrand, R., 1979, Compilation and correlation of major thermal maturation indicators: American Association of Petroleum Geologists Bulletin, v. 63, p. 21282144.

Hood, A., Gutjahr, C.C.M., and Heacock, R.L., 1975, Organic metamorphism and the generation of petroleum: American Association of Petroleum Geologists Bulletin, v. 59, p. 986-966.

Howell, D.G., Bird, K.J., Lu Huafu, and Johnsson, M.J., 1992, Tectonics and petroleum potential of the Brooks Range fold-andthrust belt-A progress report, in Bradley, D.C., and Ford, A., eds., Geologic studies in Alaska by the U.S. Geological Survey, 1990: U.S. Geological Survey Bulletin 1999, p. 112-126.

Howell, D.G., Johnsson, M.J., Underwood, M.B., Lu Huafu, and Hillhouse, J.W., 1992, Tectonic evolution of the Kandik region, east-central Alaska, in Bradley, D.C., and Ford, A., eds., Geologic studies in Alaska by the U.S. Geological Survey, 1990: U.S. Geological Survey Bulletin 1999, p. 127-140.

Johnsson, M.J., Howell, D.G., and Bird, K.J., 1993, Thermal maturity patterns in Alaska: Implications to tectonic evolution and hydrocarbon potential: American Association of Petroleum Geologists Bulletin, v. 77, p. 1874-1903.

Johnsson, M.J., Pawlewicz, M.J., Harris, A.G., and Valin, Z.C., 1992, Vitrinite reflectance and conodont color alteration index data from Alaska: Data to accompany the thermal maturity map of Alaska: U.S. Geological Survey Open-File Report 92-409, 3 diskettes.

Jones, D.L., Silberling, N.J., Coney, P.J., and Plafker, G., 1987, Lithotectonic terrane map of Alaska (west of the 141st meridian): U.S. Geological Survey Miscellaneous Field Studies Map MF-1874-A, 1 sheet, scale 1:2,500,000.

Kirschner, C.E., 1988, Map showing sedimentary basins of onshore and continental shelf areas, Alaska: U.S. Geological Survey Miscellaneous Investigations Map I-1873, 1 sheet, scale $1: 2,500,000$.

Kirschner, C.E., 1994, Interior Basins, in Plafker, E., and Berg, H.C., eds., The Geology of Alaska: Boulder, Colorado, Geological Society of America, The Geology of North America, v. G1, p. 469-494.

Laughland, M.W., Underwood, M.B., and Wiley, T.J., 1990, Thermal maturity, tectonostratigraphic terranes, and regional tectonic history: An example from the Kandik area, east-central Alaska, in Nuccio, V.F., and Barker, C.E., eds., Applications of thermal maturity studies to energy exploration: Rocky Mountain Section, Society of Economic Paleontologists and Mineralogists, p. 97-112.

Magoon, L.B., and Bird, K.J., 1988, Evaluation of petroleum source 
rocks in the National Petroleum Reserve in Alaska, using organic-carbon content, hydrocarbon content, visual kerogen, and vitrinite reflectance, in Gryc, G., ed., Geology and exploration of the National Petroleum Reserve in Alaska, 1974 to 1982: U.S. Geological Survey Professional Paper 1399, p. 381-450.

Magoon, L.B., and Claypool, G.E., 1981, Petroleum geology of Cook Inlet Basin-An exploration model: American Association of Petroleum Geologists Bulletin, v. 65, p. 1043-1061.

-1988, Geochemistry of oil occurrences, National Petroleum Reserve in Alaska, in Gryc, G., ed., Geology and exploration of the National Petroleum Reserve in Alaska, 1974 to 1982: U.S. Geological Survey Professional Paper 1399, p. 519-549.

Magoon, L.B., Woodward, P.V., Banet, A.C., Jr., Griscom, A.B., and Daws, T.A., 1987, Thermal maturity, richness, and type of organic matter of source rock units, in Bird, K.J., and Magoon, L.B., eds., Petroleum geology of the northern part of the Arctic National Wildlife Refuge, northeastern Alaska: U.S. Geological Survey Bulletin 1778, p. 127-179.

Merritt, R.D., 1985a, Coal atlas of the Matanuska Valley, Alaska: Alaska Division of Geological and Geophysical Surveys Public-Data File 85-45, 270 p.

1985b, Coal atlas of the Nenana Basin, Alaska: Alaska Division of Geological and Geophysical Surveys Public-Data File 85-41, 197 p.

-1986a, Depositional environments and resource potential of Cretaceous coal-bearing strata at Chignik and Herendeen Bay, Alaska Peninsula: Alaska Division of Geological and Geophysical Surveys Public-Data File 86-72, 20 p.

1986b, Geology and coal resources of the Wood River Field, Nenana basin: Alaska Division of Geological and Geophysical Surveys Public-Data File 85-41, 11 p.

1990, Coal resources of the Susitna Lowland, Alaska: Alaska Division of Geological and Geophysical Surveys Report of Investigations 90-1, $181 \mathrm{p}$.

Merritt, R.D., and McGee, D.L., 1986, Depositional environments and resource potential of Cretaceous coal-bearing strata at Chignik and Herendeen Bay, Alaska Peninsula: Sedimentary Geology, v. 49, p. 21-49.

Orchard, M.J., 1987, Conodonts from western Canadian chert: Their nature, distribution and stratigraphic application, in Austin, R.L., ed., Conodonts: Investigative techniques and applications: Chichester, United Kingdom, Ellis Horwood Ltd. and British Micropalaeontological Society, p. 94-119.

Patton, W.W., and Tailleur, I.L., 1977, Evidence in the Bering Strait region for differential movement between North America and Eurasia: Geological Society of America Bulletin, v. 88, p. 12981304.

Pawlewicz, M.J., 1987, Polishing method for dispersed vitrinite and coal slides: The Society for Organic Petrology Newsletter, v. 4, p. 1.

Plafker, G., 1990, Regional geology and tectonic evolution of Alaska and adjacent parts of the northeast Pacific Ocean margin, in Proceedings of the Pacific Rim Congress 90: Queensland, Australia, Australian Institute of Mining and Metallurgy, p. 841853.

Poole, F.G., and Claypool, G.E., 1984, Petroleum source-rock potential and crude-oil correlation in the Great Basin, in Woodward, W., Meissner, F.F., and Clayton, J., eds., Hydrocarbon source rocks of the greater Rocky Mountain region: Denver, Colorado, Rocky Mountain Association of Geologists, p. 179-229.
Price, L.C., 1983, Geologic time as a parameter in organic metamorphism and vitrinite reflectance as an absolute paleogeothermometer: Journal of Petroleum Geology, v. 6, p. 5-38.

Rao, P.D., 1980, Petrographic, mineralogical, and chemical characterization of certain Arctic Alaskan coals from the Cape Beaufort region: Alaska Division of Geological and Geophysical Surveys Mineral Industry Research Laboratory Report 44, 66 p.

Rao, P.D., and Smith, J.E., 1983, Petrology of Cretaceous coals from northern Alaska: Alaska Division of Geological and Geophysical Surveys Mineral Industry Research Laboratory Report 64, $141 \mathrm{p}$.

Reifenstuhl, R.R., 1990, Vitrinite reflectance data for some early Tertiary through Jurassic outcrop samples, northeastern Alaska: Alaska Division of Geological and Geophysical Surveys Public Data File 90-5a, 3 p.

Rejebian, V.A., Harris, A.G., and Huebner, J.S., 1987, Conodont color and textural alteration: An index to regional metamorphism, contact metamorphism, and hydrothermal alteration: Geological Society of America Bulletin, v. 99, p. 471-479.

Robinson, M.S., 1989, Kerogen microscopy of coal and shales from the North Slope of Alaska: Alaska Division of Geological and Geophysical Surveys Public Data File 89-22, 19 p.

Smith, J., and Rao, P.D., 1986, Geology and coal resources of the Bering River Coal Field, in Focus on Alaska's Coal '86, Proceedings of the conference held at Anchorage, Alaska October 27-30, 1986: Fairbanks, Alaska, Mineral Industry Research Laboratory, p. 266-299.

Stanley, R.G., 1987, Thermal maturity and petroleum source potential of the Cantwell Formation (Paleocene), Alaska Range, in Hamilton, T.D., and Galloway, J.P., eds., Geologic studies in Alaska by the U.S. Geological Survey during 1986: U.S. Geological Survey Circular 998, p. 104-107.

1988, Hydrocarbon source potential and thermal maturity of the Sanctuary Formation (Middle Miocene), northern foothills of the Alaska Range, in Galloway, J.P., and Hamilton, T.D., eds., Geologic Studies in Alaska by the U.S. Geological Survey during 1987: U.S. Geological Survey Circular 1016, p. 117120.

Stanley, R.G., McLean, H., and Pawlewicz, M.J., 1990, Petroleum source potential and thermal maturity of the Tertiary Usibelli Group at Suntrana, central Alaska, in Dover, J.H., and Galloway, J.P., eds., Geologic studies in Alaska by the U.S. Geological Survey, 1989: U.S. Geological Survey Bulletin 1946, p. $65-76$.

Stone, J., 1987, Review of investigative techniques used in the study of conodonts, in Austin, R.L., ed., Conodonts: Investigative techniques and applications: Chichester, United Kingdom, Ellis Horwood Ltd. and British Micropalaeontological Society, p. $17-34$.

Suzuki, N., Matsubayashi, H., and Waples, D.W., 1993, A simpler kinetic model of vitrinite reflectance: American Association of Petroleum Geologists Bulletin, v. 77, p. 1502-1508.

Sweeney, J.J., and Burnham, A.K., 1990, Evaluation of a simple model of vitrinite reflectance based on chemical kinetics: American Association of Petroleum Geologists Bulletin, v. 74, p. $1559-1570$.

Underwood, M.B., Brocculeri, T., Bergfeld, D., Howell, D.G., and Pawlewicz, M., 1992, Statistical comparison between vitrinite reflectance and illite crystallinity, Kandik River and Tatonduk 
terranes, east-central Alaska, in Bradley, D., and Dusel-Bacon, C., eds., Accomplishments in Alaska by the U.S. Geological Survey, 1991: U.S. Geological Survey Bulletin 2041, p. 222237.
Underwood, M.B., Laughland, M.M., Wiley, T.J., and Howell, D.G., 1989, Thermal maturity and organic geochemistry of the Kandik Basin region, east-central Alaska: U.S. Geological Survey Open File Report 89-353, 41 p. 


\title{
THERMAL EVOLUTION OF SEDIMENTARY BASINS IN ALASKA
}

U.S. Geological Survey Bulletin 2142

\section{Thermal-Maturity Patterns and Geothermal Gradients on the Alaska Peninsula}

\author{
By Cornelius M. Molenaar ${ }^{1}$
}

\section{CONTENTS}

Abstract

Introduction

Geologic setting

Thermal-maturity patterns

Paleo- and present-day geothermal gradients .............. 18

Summary .................................................................

References cited .................................................. 19

\begin{abstract}
Mesozoic and Tertiary sedimentary rocks on the Alaska Peninsula, which exceed $10 \mathrm{~km}$ in thickness, were deposited initially in a volcanic arc and forearc basin setting and, later in Tertiary time, in a volcanic arc and backarc setting adjacent to a convergent continental margin. Much of the section represented by these rocks is exposed on the limbs of large amplitude folds. At the surface, the thermal maturity of these rocks, as determined mostly from vitrinite-reflectance data, generally ranges from undermature to marginally or low-range mature with respect to hydrocarbon generation. In areas adjacent to numerous granitic intrusive bodies, however, the sedimentary rocks are overmature. Slightly higher thermal maturities in Upper Cretaceous and Eocene rocks in the southwestern part of the Alaska Peninsula, in contrast to Jurassic rocks in the northeastern part, indicate that the paleogeothermal gradient was probably slightly higher in the southwest.
\end{abstract}

${ }^{1}$ Editors' note.-K Molenaar died suddenly during the preparation of this volume. He had completed and revised the manuscript for this paper, but some editing and the final drafting of figures remained. We performed this last bit of cleanup, taking care to preserve both K's meaning and his own style of expression. We believe that we have been successful in this task, but if any errors have crept in, we most wholeheartedly apologize. May this, K's last publication, stand as a memorial to his dedication to Alaskan geology.
Small differences in thermal maturities across thick sections of exposed Mesozoic sedimentary rocks indicate that the paleogeothermal gradient was very low at the time of maximum burial (probably between latest Cretaceous and late Eocene time). In contrast, the present-day geothermal gradient, as indicated by bottom-hole temperatures in wells, is above normal, averaging about $36.5^{\circ} \mathrm{C} / \mathrm{km}\left(2^{\circ} \mathrm{F} / 100 \mathrm{ft}\right)$.

\section{INTRODUCTION}

The Alaska Peninsula, an 800-km-long southwestern extension of the mainland of Alaska, is a convergent continental margin and part of the circumpacific volcanic arc that rims the Pacific Ocean. Late Cenozoic volcanoes and associated flows are present along the entire length of the peninsula, the continuation of which forms the Aleutian Islands. A cumulative thickness of about 15,000 $\mathrm{m}$ of Mesozoic and Tertiary dominantly clastic sedimentary rocks, which formed in forearc, volcanic-arc, and backarc settings, compose much of the bedrock on the peninsula. These rocks were mildly to moderately folded in late Tertiary time.

The Alaska Peninsula is about $160 \mathrm{~km}$ wide on the northeast and tapers to about $30 \mathrm{~km}$ wide on the southwest (fig. 1). Topographically, the northwestern side of the peninsula is generally flat alluvium-covered lowlands bordering Bristol Bay and the Bering Sea. In contrast, the southeastern side of the peninsula is mountainous to hilly bedrock composed of Mesozoic and Tertiary sedimentary rocks and late Cenozoic volcanic and intrusive rocks, all of which form rocky headlands bordering the Pacific Ocean.

Active oil seeps and large anticlinal structures on and adjacent to the Alaska Peninsula have been of interest to oil explorers for many years. Not counting a few shallow wells drilled near oil seeps, 18 exploratory wells ranging in depth from 1,534 m (5,034 ft) (drill hole 1, fig. 1) to 4,577 m (15,015 ft) (drill hole 9, fig. 1) have been drilled. Much geological and some geochemical data have been acquired from both surface geological work and the drilling of the wells. Avail- 


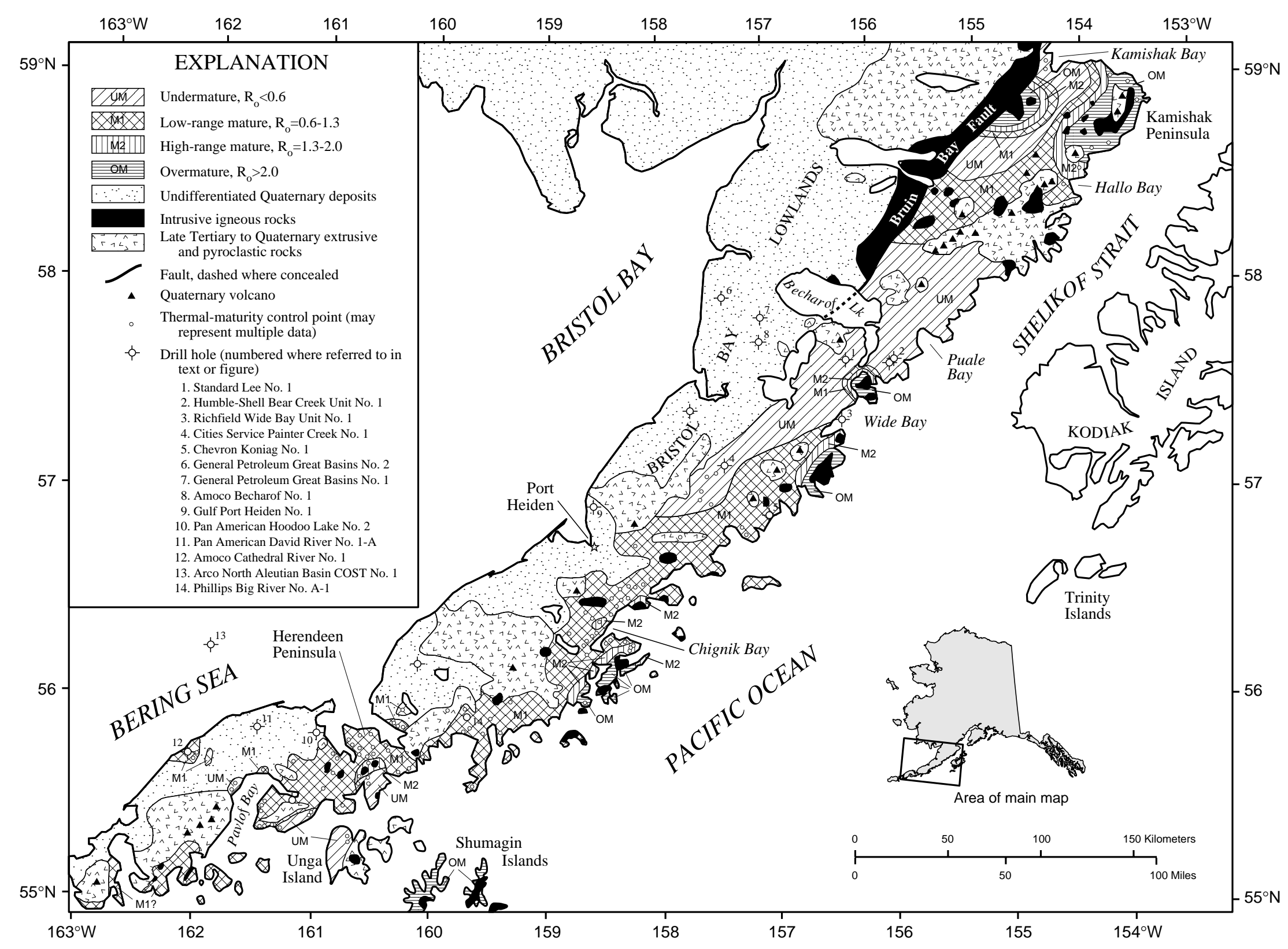

$\bar{N}$

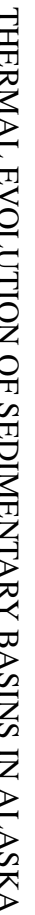

Figure 1. Map of Alaska Peninsula showing igneous intrusive and extrusive rocks, thermal maturity of sedimentary rocks at the surface, and drill holes. Mapped igneous rocks modified from Riehle and others (1987), Detterman and others (1981, 1987), Wilson and others (1991), and Beikman (1980). $\mathrm{R}_{\mathrm{o}}$, vitrinite reflectance in percent. 
able thermal-maturity data from wells and outcrops indicate that, at the surface, most of the sedimentary rocks range from immature to low-range mature in terms of hydrocarbon generation. However, the rocks are overmature in some areas, a condition which is due to the proximity of igneous intrusions. The purpose of this report is to show and discuss thermal-maturation patterns on the Alaska Peninsula, to show the available subsurface thermal-maturity data from wells, and to compare present-day geothermal gradients with inferred paleogeothermal gradients at the time that rocks now at the surface were subjected to maximum heating, that is, maximum depth of burial.

Vitrinite reflectance was the primary data type used in evaluating the thermal-maturation patterns on the Alaska Peninsula. Vitrinite-reflectance values from about 410 outcrop samples were available from the peninsula. Shell Oil Company provided about 330 data points and Chevron provided about 40 ; their contributions are greatly appreciated. In addition, much of the vitrinite-reflectance data for the Chignik Formation (Upper Cretaceous) in the Chignik Bay and Herendeen Peninsula areas are from coal characterization studies of Merritt and McGee (1986). Outcrop vitrinite-reflectance data points or groups of data points used in the present study are shown on figure 1, as thermal-maturity control points. Some of these control points represent many samples, especially in the Chignik Bay and Herendeen Peninsula areas.

Vitrinite-reflectance data also are available for 10 wells on the Alaska Peninsula, as well as one offshore well. Data for eight of these wells were acquired from available reports at the Alaska Geological and Geophysical Survey Geological Materials Center. These data are the result of various companies or individuals determining vitrinite-reflectance values from well cuttings provided by the Geological Materials Center.

All the outcrop vitrinite-reflectance data and the vitrinite-reflectance data for the eight wells referred to above are listed by Johnsson and others (1992) in a database for all of Alaska.

The present-day geothermal gradient was calculated from bottom-hole temperatures from wells drilled on the Alaska Peninsula. The calculated adjusted bottom-hole temperatures (the final temperatures at equilibrium) are only approximate because the circulation time of the drilling fluid and the times elapsed between fluid circulation and the measurement of bottom-hole temperatures are poorly known. A bottom-hole temperature correction chart for various depths adapted by the Geothermal Gradients Committee of the American Association of Petroleum Geologists was used in calculating the present geothermal gradients. Despite the possible inaccuracies in the calculations, the results are considered good enough to determine an approximate geothermal gradient.

\section{GEOLOGIC SETTING}

The Alaska Peninsula, an allochthonous terrane, is part of a convergent continental margin that was accreted to mainland Alaska approximately 100 to $55 \mathrm{Ma}$ (Hillhouse, 1987). The southwest end of the peninsula is continuous with the present late Cenozoic Aleutian Island Arc. Sedimentary rocks exposed on the peninsula range in age from mid-Permian (exposed only on a small island near Puale Bay, fig. 1) to late Tertiary (fig. 2). Most of the Mesozoic sediments were deposited in a volcanic arc or forearc basin setting directly southeast (present-day orientation) of the uplifted arc. However, Wang and others (1988) interpreted a backarc setting during the Upper Triassic. The Tertiary sediments were deposited in a volcanic-arc and backarc setting in which Tertiary rocks underlie the Bristol Bay Lowlands southwest of Becharof Lake (fig. 1) and extend under Bristol Bay to the west. Figure 2 shows the stratigraphic column for the Alaska Peninsula and includes thickness ranges and comments on the general lithologies and depositional environments.

The northeastern part of the Alaska Peninsula is divided into two geologic entities by the Bruin Bay Fault, which extends from the west side of lower Cook Inlet directly northeast of the map area of figure 1 to Becharof Lake on the southwest. The northwest side of the fault consists of Early and Middle Jurassic granitic rocks of the Alaska-Aleutian Range batholith, associated metamorphic rocks, and Tertiary volcanic rocks (Riehle and others, 1989). The southeast side of the Bruin Bay Fault consists mostly of Mesozoic clastic sedimentary rocks that were derived from the Jurassic volcanic rocks and the batholithic roots of the uplifted volcanic arc to the northwest of the Bruin Bay Fault. Although the presentday Bruin Bay Fault is a post-Jurassic feature, it coincided with or paralleled a similar fault that was active during Jurassic time.

The Bruin Bay Fault is covered by alluvium southwest of Becharof Lake. Gravity data suggest that this fault extends under the Bristol Bay Lowlands to the Port Heiden area (fig. 1) (Barnes, 1977). Drill holes indicate that a thick section of Tertiary rock underlies the lowlands southwest of Becharof Lake. Therefore, the Tertiary movement of this fault or a paralleling fault in this area is opposite (down to the northwest) of the movement north of Becharof Lake.

The cumulative thickness of Mesozoic rocks, which constitute most of the bedrock in the northeastern part of the Alaska Peninsula, is at least 9,000 m (unpublished data), but the average thickness at most localities is much less, owing to lateral thickness variations, truncation under Mesozoic and Tertiary unconformities, and late Tertiary and Quaternary erosion (fig. 2). Upper Triassic and Lower Jurassic rocks are exposed only on the northeast side of Puale Bay (fig. 1) and were deposited along an active volcanic arc. The Jurassic arc volcanism peaked in the Early Jurassic and was followed by uplift of the volcanic arc, which was the source for Middle and Upper Jurassic rocks. The granitic roots of the volcanic 
arc provided the arkosic debris that characterized Late Jurassic sedimentation. Lower Cretaceous rocks are relatively thin, consisting of shallow marine sandstone and mudstone. After a long hiatus, Late Cretaceous deposition resumed and is represented by fluvial to deltaic lithic sandstone overlain by a thick section of deep-marine mudstone and lesser amounts of turbiditic sandstone.
Tertiary rocks, which constitute an increasing percentage of outcrops toward the southwestern part of the Alaska Peninsula, have a maximum thickness of about $5,400 \mathrm{~m}$ (Detterman and others, in press). Early Tertiary (Tolstoi Formation) rocks, consisting dominantly of nonmarine sandstone, mudstone, conglomerate, and minor coal, unconformably overlie a broadly warped surface of Mesozoic rocks. The

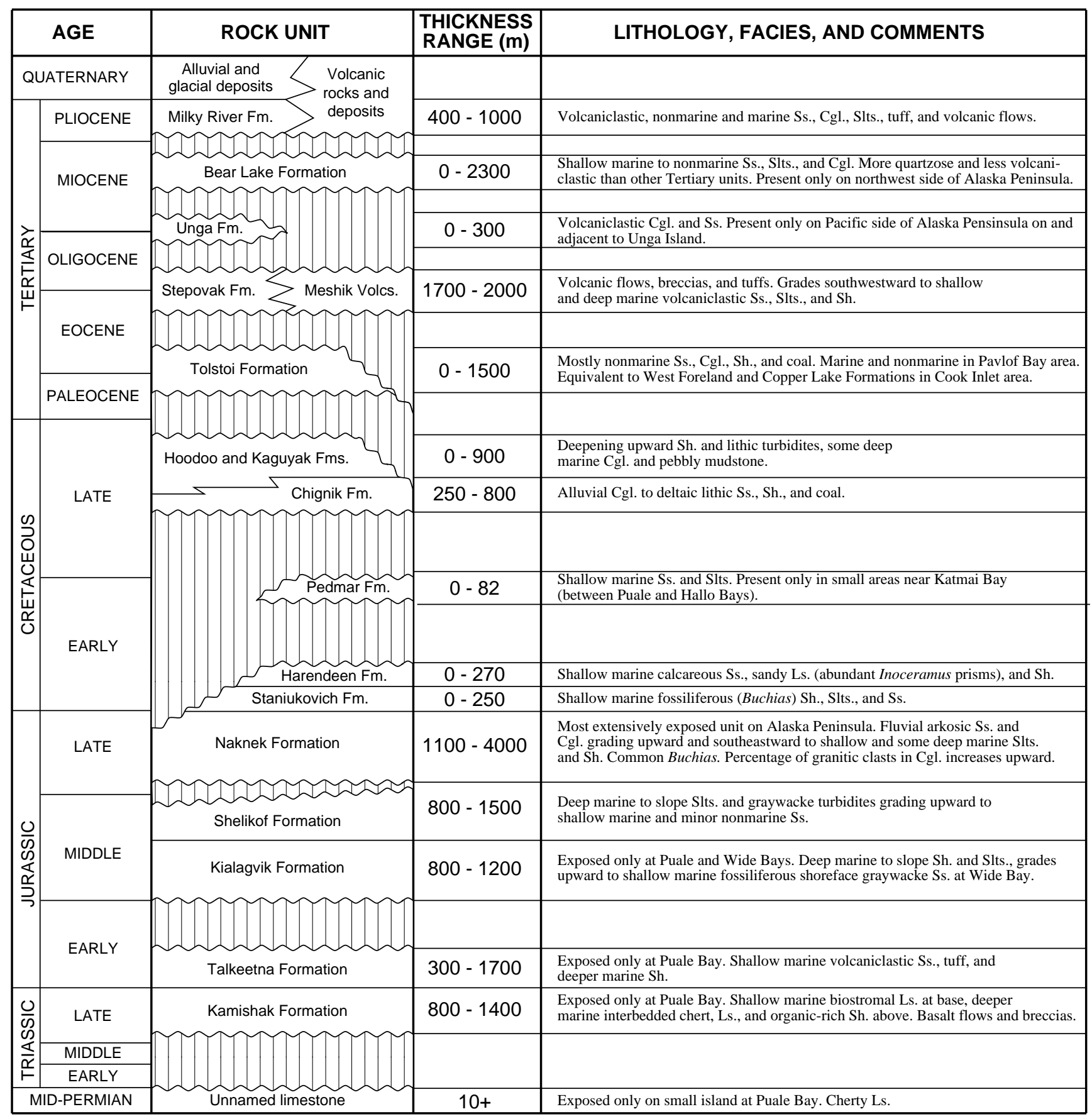

Figure 2. Stratigraphic column for Alaska Peninsula (modified from Detterman and others, in press). Ss., sandstone; Cgl., conglomerate; Slts., silts; Sh., shale; Ls., limestone. See figure 1 for localities mentioned in comments. 
Meshik volcanic arc (Wilson and others, 1985) was active during late Eocene and Oligocene time and was followed after a brief hiatus by the present volcanic arc, which became active during the Miocene (Detterman and others, in press). Most postEocene sedimentary rocks were derived from detritus of these volcanic deposits. Late Tertiary deformation resulted in the formation of large gently to moderately folded structures that generally parallel the peninsula. The structural relief from anticlinal axis to synclinal axis is as much as 6,000 $\mathrm{m}$ (Burk, 1965).

Numerous late Miocene and Pliocene igneous intrusions (composed of quartz diorite and other granitic rocks), a few of which are of small batholith size, as well as late Cenozoic volcanoes associated with the present-day volcanic-arc system, exist along the length of the Alaska Peninsula (fig. 1). These intrusions locally increased the thermal maturity of adjacent sedimentary rocks.

\section{THERMAL-MATURATION PATTERNS}

Most of the outcrop vitrinite-reflectance data are in the southwestern part of the Alaska Peninsula between Pavlof Bay on the southwest and the Painter Creek well on the northeast (drill hole 4, fig. 1). There are no outcrop vitrinite-reflectance data between the Painter Creek well and Hallo Bay (fig. 1), about $40 \mathrm{~km}$ south of the Kamishak Peninsula at the northeast end of the Peninsula. However, vitrinite-reflectance data from the Wide Bay and Bear Creek wells (drill holes 2 and 3, respectively, fig. 1), as well as Rock-Eval pyrolysis data from outcrop samples from the Puale Bay area, help in evaluating the area between the Painter Creek well and Hallo Bay. In addition to the outcrop data, vitrinite-reflectance data from 10 onshore wells and one offshore well are plotted on depth plots in figures 3 to 5 . In both outcrop and well data,
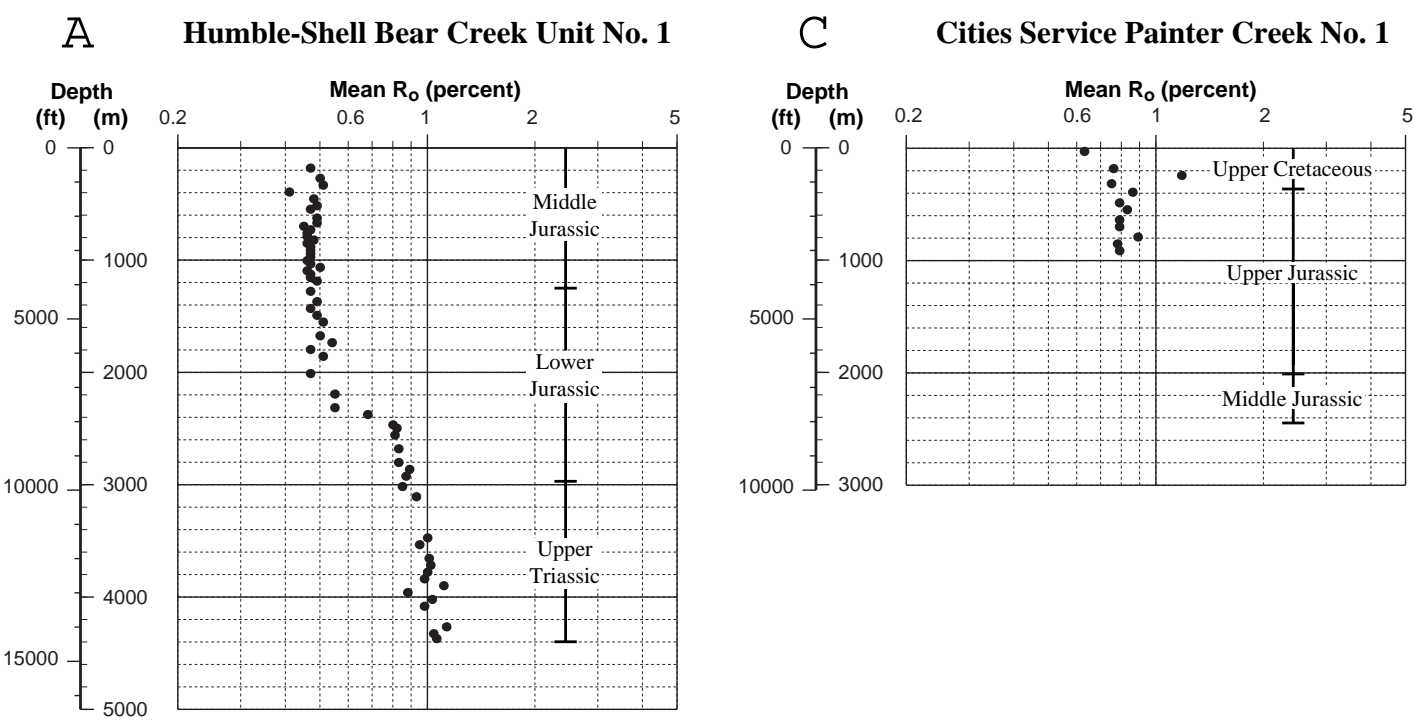

\section{B}

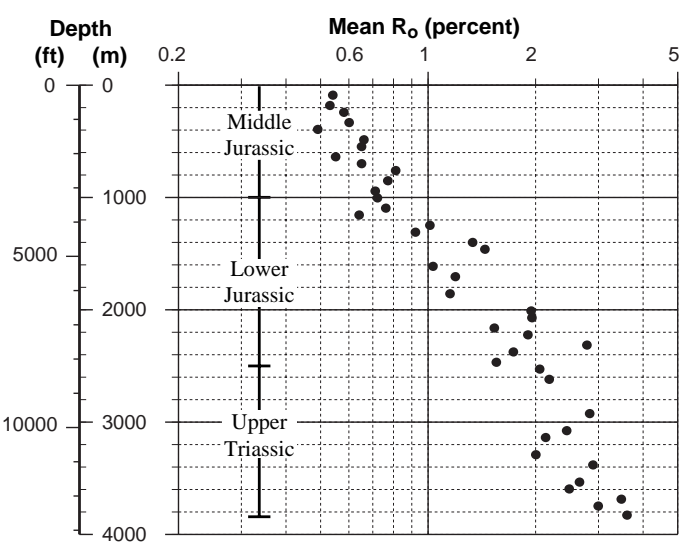

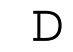

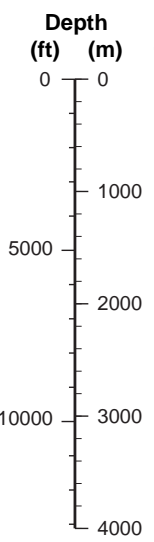

\section{Chevron Koniag No. 1}

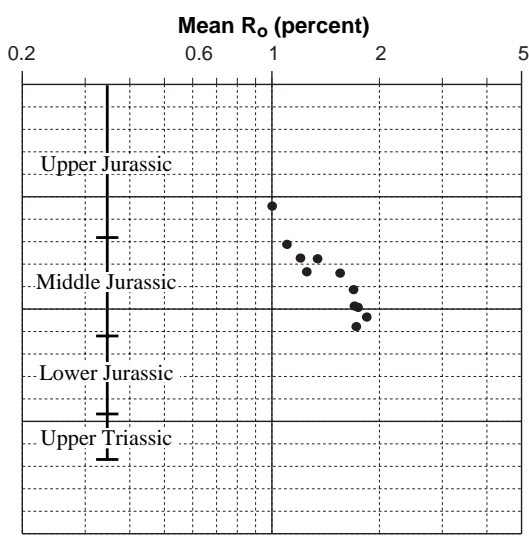

Figure 3. Vitrinite reflectance (thermal maturity) versus depth plots for four wells from the Puale Bay-Wide Bay area on the Alaska Peninsula. See figure 1 for location of wells. Vitrinite-reflectance data from unpublished reports of the Alaska Geological Materials Center, Eagle River, Alaska. 
the mean vitrinite-reflectance values are used. In general, rocks unaffected by igneous intrusions are undermature in the northeastern part of the Alaska Peninsula and marginally or low-range mature in the southwestern part of the peninsula. This is despite the fact that most of the rocks are younger in the southwestern part. Either the geothermal gradient was greater to the southwest or these rocks were buried deeper by a thicker overlying section of Tertiary rocks that was subsequently eroded.

In constructing the thermal-maturity map of the Alaska Peninsula (fig. 1), four maturation ranges are used. These ranges are similar to those used in the more general thermalmaturity map of Alaska (pl. 1). These are (1) undermature, $\mathrm{R}_{\mathrm{o}}<0.6$, (2) mature 1 (low-range mature), $\mathrm{R}_{\mathrm{o}}=0.6$ to 1.3 , (3) mature 2 (high-range mature), $\mathrm{R}_{\mathrm{o}}=1.3$ to 2.0 , and (4) overmature, $R_{0}>2.0$ (in plate 1 , the overmature range is sepa- rated into two categories-overmature, $\mathrm{R}_{\mathrm{o}}=2.0$ to 3.6 , and supermature, $\mathrm{R}_{\mathrm{o}}>3.6$.).

All outcropping sedimentary rocks of the Alaska Peninsula not in the immediate vicinity of intrusive rocks are undermature or low-range mature. Because of the small map scale, the generalized maturity patterns shown on figure 1 do not include the higher maturity halos that are probably present around the smaller intrusive bodies. Inferred or measured high-maturity halos are shown around the larger intrusions. Except for the Kamishak Peninsula area (to be discussed), there are no data to substantiate the halo effect because areas where the effect may be expected were avoided in the sampling programs. The halo effect is usually noticed in the field by greater induration or hardness of the shales and, in some cases, the alteration to hornfels (Detterman and others, 1983). Unusually high maturity values in a few areas may be due to
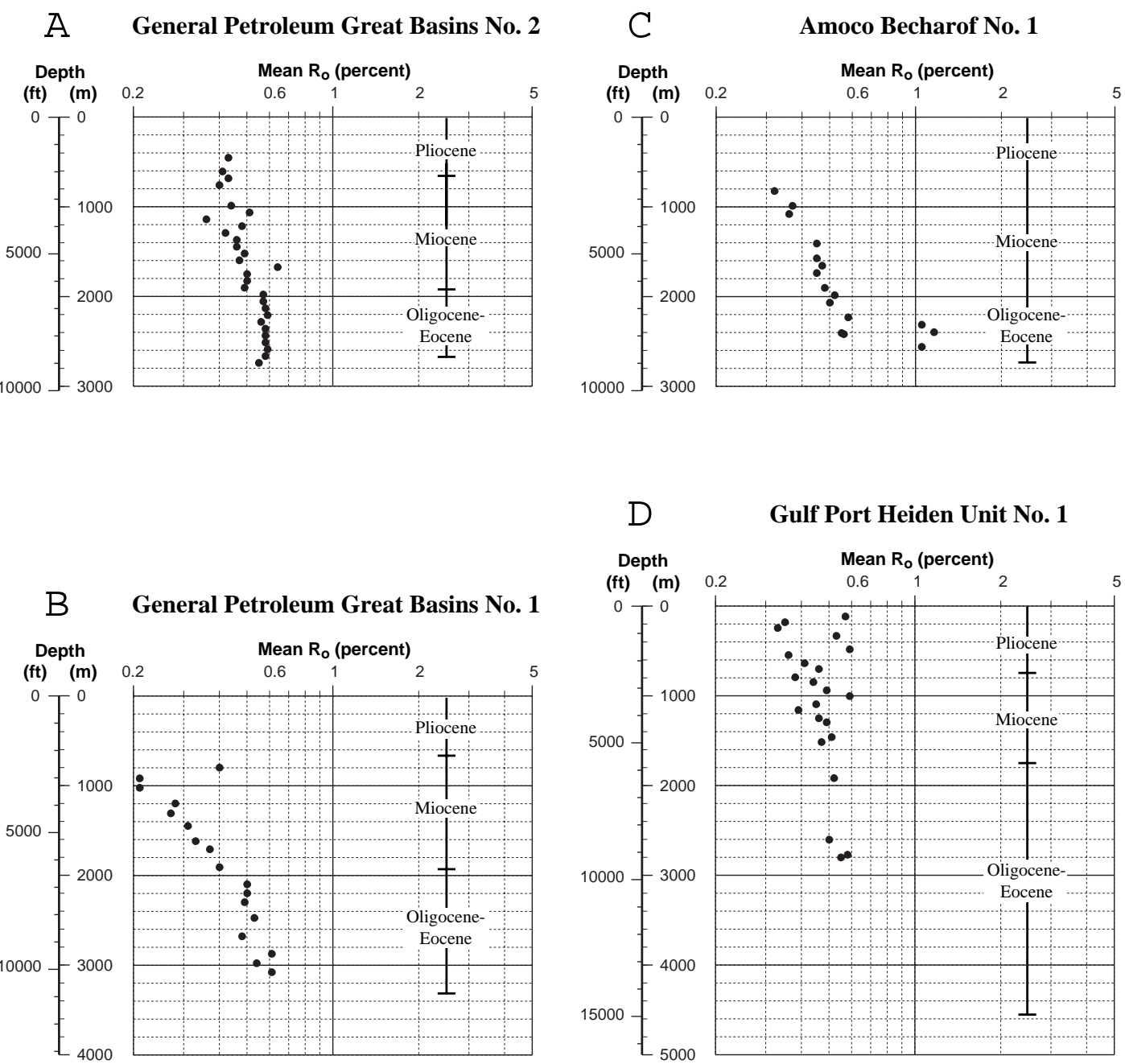

Figure 4. Vitrinite reflectance (thermal maturity) versus depth plots for four wells from the Bristol Bay Lowlands on the Alaska Peninsula. See figure 1 for location of wells. Vitrinite-reflectance data for $A, C$, and $D$ from unpublished reports of the Alaska Geological Materials Center, Eagle River, Alaska; vitrinite-reflectance data for $B$ from McLean (1977). 


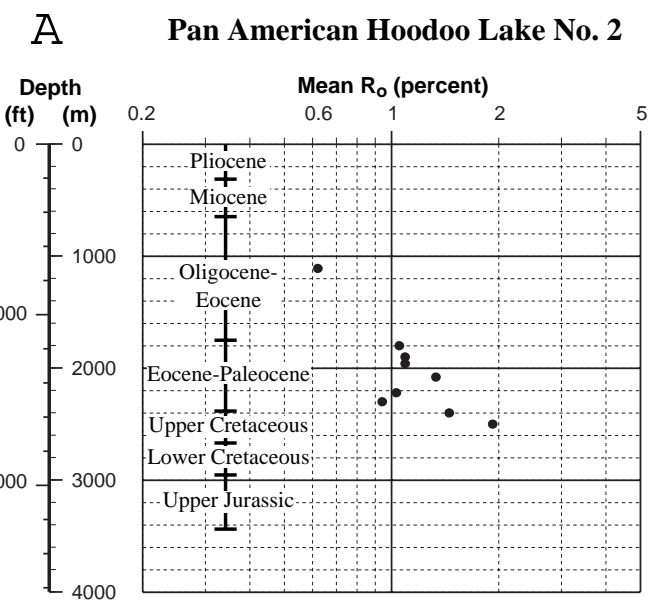

B Pan American David River No. 1-A

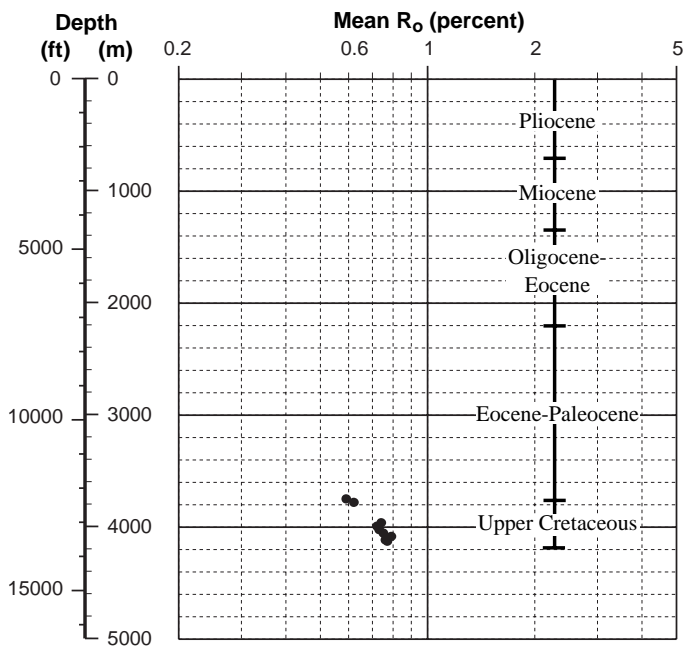

C Arco North Aleutian Shelf COST No. 1

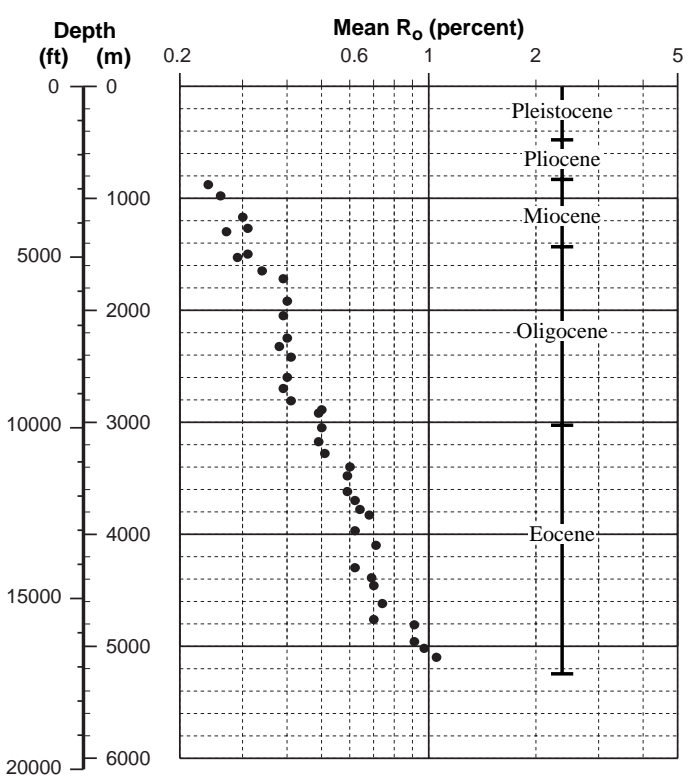

underlying intrusive rocks not exposed at the surface. The thermal maturities of areas on the Alaska Peninsula are discussed from northeast to southwest as follows.

Upper Jurassic and Lower Cretaceous rocks in the northwestern and western parts of the Kamishak Peninsula are in the undermature range. However, Eocene rocks on the northeast and east side and Upper Cretaceous rocks on the south side of the peninsula are overmature (fig. 1). The high thermal maturation is due to the large intrusive body shown in figure 1. This intrusion is in a highly glaciated area, which culminates in Mt. Douglas (a 2,134-m-high volcano). Because of the volcanic and glacier cover (not shown in figure 1), the areal extent of the intrusion is probably much greater than shown. The Kamishak Peninsula is the only area where vitrinite-reflectance data are available to document the halo effect around intrusive bodies.

Vitrinite-reflectance data are not available in the area between Hallo Bay and the Puale Bay-Becharof Lake area (fig. 1). Except for some Cretaceous and Tertiary rocks exposed along the northern part of the coastline and Middle Jurassic rocks along the southern part of the coastline, the Upper Jurassic Naknek Formation and late Tertiary and Quaternary volcanic rocks constitute most of the bedrock in this area. Because similar-age sedimentary rocks to the northeast and southwest of this area are undermature, the sedimentary rocks within the area are also inferred to be undermature, except where near an intrusive body.

Outcrop vitrinite-reflectance data are not available in the Puale Bay-Wide Bay area. However, data available from two deep drill holes, one on the Bear Creek anticline (drill hole 2, fig. 1) and one on the Wide Bay anticline (drill hole 3, fig. 1), indicate that Middle Jurassic rocks at shallow depths in this area are undermature (fig. 3). In addition, Rock-Eval pyrolysis data indicate that Upper Triassic rocks exposed in the Puale Bay area are undermature to barely mature (Magoon and Anders, 1992; Wang and others, 1988). Inasmuch as these are the oldest rocks in the area, it is likely that surface rocks in the entire greater Puale Bay area are undermature. Directly south of Wide Bay, however, there is a large late Tertiary granitic intrusive body that is surrounded by a zone of hornfels or overmature sedimentary rocks (Detterman and others, 1983). In the subsurface, the thermal-maturity values increase rapidly with depth in the Wide Bay drill hole, where Lower Jurassic and Upper Triassic rocks are in the high to overmature range. These high values are undoubtedly due to a nearby intrusion at depth because these same rocks at a slightly greater depth in the Bear Creek well are at the low range of thermal maturity (fig. 3). Similarly, farther southwest in the Koniag well (drill hole 5, fig. 1), the thermal-maturity values also

Figure 5. Vitrinite reflectance (thermal maturity) versus depth plots for three wells on or adjacent to the Bristol Bay Lowlands on the Alaska Peninsula. Vitrinite-reflectance data for $A$ from McLean (1977); $B$ from Alaska Geological Material Center, Eagle River, Alaska, and $C$ from Flett (1988). 
increase rapidly with depth, a condition which is also probably due to an intrusive body at depth near the well.

Large oil seeps occur near the crest of the Ugashik anticline (near drill hole 1, fig. 1) and on the Bear Creek anticline (near drill hole 2, fig. 1). These seeps attest to the fact that mature source rocks are present at depth, probably Upper Triassic and (or) possibly Middle Jurassic rocks. The oil probably migrated to the surface via faults or fractures.

A few vitrinite-reflectance control points around the Painter Creek well (drill hole 4, fig. 1) and the area east of Port Heiden indicate that the line separating undermature rocks to the north from low-range mature rocks to the south trends southwest from the south end of Wide Bay (fig. 1). Even though surface rocks are younger on the southwestern part of the Alaska Peninsula than on the northeastern part, the numerous vitrinite-reflectance data indicate that generally the thermal-maturation level is higher in the southwestern part of the peninsula. Near intrusive rocks, of course, the thermalmaturation values are in the high-range mature and overmature ranges and a few areas, mostly in younger Tertiary rocks, are in the undermature range (many of the latter areas are too small to show on figure 1). The high-range mature rocks shown a few kilometers inland from Chignik Bay are Middle Jurassic rocks (Shelikof Formation) exposed along the crest of the Chignik anticline (fig. 1, Chignik anticline not marked). Because at least 4,000 m of strata was removed by erosion from the crest of the anticline, the high thermal maturation is attributed to heating related to burial rather than to the presence of a nearby intrusive body.

The Bristol Bay Lowlands are alluvium-covered, but well data indicate that the lowlands are underlain by a fairly thick section of middle and late Tertiary rocks (figs. 4, 5). Available vitrinite-reflectance data from five of the wells in the lowlands show the shallow rocks to be undermature and that marginally mature rocks $\left(\mathrm{R}_{\mathrm{o}}=0.6\right)$ should occur at about 3,000 m depth (figs. 4 and 5). At the Amoco Cathedral River well (drill hole 12, fig. 1), which spudded into low-range mature rocks of the Upper Jurassic Naknek Formation on the north side of the Alaska Peninsula northwest of Pavlof Bay, a vitrinite-reflectance value of $R_{0}=1.47$ at about $3,350 \mathrm{~m}$ was reported by Peters (1986, p. 325). The thermal-maturation plot of the Arco North Aleutian Shelf COST well (drill hole 13, fig. 1) is shown in figure 5 for comparison with the thermal-maturation data from the wells nearby on the Bristol Bay Lowlands. Marginal thermal-maturation $\left(\mathrm{R}_{\mathrm{o}}=0.6\right)$ occurs at about 3,500 $\mathrm{m}$ depth in the COST well, which is slightly deeper than in the onshore Tertiary test wells.

\section{PALEO AND PRESENT-DAY GEOTHERMAL GRADIENTS}

Rocks exposed at the surface on the Alaska Peninsula are generally in the immature or low range of thermal maturity (excluding those near intrusions). When considering the depth of burial that many of these rocks were subjected to, it seems that the paleogeothermal gradient at that time was very low. For example, the Triassic rocks exposed at Puale Bay, which are immature to barely mature, were buried by at least 4,000 m of Jurassic rocks plus an unknown amount of noweroded section of Cretaceous and probable early Tertiary rocks. In addition, rocks exposed on the flanks of the Chignik anticline, representing 4,000 m of Upper Jurassic strata plus at least 1,000 m of Cretaceous strata, show a thermal-maturation range of only about $R_{o}=0.6$ to $R_{o}=1.6$. Both of these examples indicate that the paleogeothermal gradient was very low at the time of maximum burial (and presumed maximum burial temperature), which was probably between latest Cretaceous and late Eocene time.

It can be argued that the thick sections discussed above were not as thick on top of the Chignik anticline or above the oldest strata in the Puale Bay region. Depositional thinning over existing structures could have been significant inasmuch as the thick sections referred to in both examples are on the northwestern flanks of structures, which is the direction of depositional thickening. Even with these possibilities, however, the case for a low paleogeothermal gradient is good.

In contrast to the low paleogeothermal gradient indicated above, the present-day geothermal gradient in the volcanic arc or outcrop part of the Alaska Peninsula as determined from bottom-hole temperatures in wells is above the norm for sedimentary basins (about $27.3^{\circ} \mathrm{C} / \mathrm{km}$ or $1.5^{\circ} \mathrm{F} / 100$ $\mathrm{ft})$, ranging from $33.7^{\circ}$ to $41.9^{\circ} \mathrm{C} / \mathrm{km}\left(1.85^{\circ}\right.$ to $\left.2.3^{\circ} \mathrm{F} / 100 \mathrm{ft}\right)$ and averaging about $36.5^{\circ} \mathrm{C} / \mathrm{km}\left(2^{\circ} \mathrm{F} / 100 \mathrm{ft}\right)$. One well (drill hole 14, fig. 1), which had a gradient of at least $60.1^{\circ} \mathrm{C} / \mathrm{km}$ $\left(3.3^{\circ} \mathrm{F} / 100 \mathrm{ft}\right)$, was not used in the averaging because it undoubtedly was drilled in an abnormally hot area.

The present-day geothermal gradient as indicated by wells drilled in the backarc Bristol Bay Lowlands ranges from $29.2^{\circ}$ to $38.3^{\circ} \mathrm{C} / \mathrm{km}\left(1.6^{\circ}\right.$ to $\left.2.1^{\circ} \mathrm{F} / 100 \mathrm{ft}\right)$ and averages about $34.6^{\circ} \mathrm{C} / \mathrm{km}\left(1.9^{\circ} \mathrm{F} / 100 \mathrm{ft}\right)$, which is only slightly lower than that of the volcanic arc part of the Alaska Peninsula. Another comparison of paleo- and present-day geothermal gradients can be made from well data in the Bristol Bay Lowlands, where Tertiary rocks are at or near their maximum burial depths. There, the depth to marginally mature rocks $\left(\mathrm{R}_{\mathrm{o}}=0.6\right)$ is about 3,000 m (fig. 4). In contrast, Triassic rocks at Puale Bay, which have been buried to depths greater than 4,000 m, are only barely mature, indicating that the Mesozoic paleogeothermal gradient must have been much lower than the present-day geothermal gradient in the Bristol Bay Lowlands.

\section{SUMMARY}

The sedimentary rocks of the Alaska Peninsula consist of 6,000 to $9,000 \mathrm{~m}$ of Mesozoic volcanic arc and forearc basin rocks plus about 5,400 m of Tertiary volcanic arc and backarc basin rocks. As much as 6,000 $\mathrm{m}$ of these rocks are 
exposed on the flanks of some of the large late Tertiary folds. Vitrinite-reflectance data from outcrops and wells indicate that, except for the thermal effect of nearby intrusive rocks, most of the surface rocks in the northeastern part of the Alaska Peninsula are undermature and that most of the surface rocks in the southwestern part of the peninsula are in the low range of maturity. Because the surface rocks in the southwestern part are generally younger than those in the northeastern part, it seems that either (1) the southwestern part was buried deeper by now-eroded younger Tertiary rocks or, (2) more likely, there was a higher paleogeothermal gradient in the southwestern area.

Because of the relatively small differences in thermal maturities from the top to the bottom of thick sections of exposed Mesozoic rocks on the Alaska Peninsula, the paleogeothermal gradient was very low at the time of maximum burial (probably between latest Cretaceous and Eocene time). In contrast, the present-day geothermal gradient as indicated by bottom-hole temperature data from wells is above normal, averaging about $36.5^{\circ} \mathrm{C} / \mathrm{km}\left(2^{\circ} \mathrm{F} / 100 \mathrm{ft}\right)$.

\section{REFERENCES CITED}

Barnes, D.F., 1977, Bouguer gravity map of Alaska: U.S. Geological Survey Geophysical Investigations Map GP-913, scale 1:2,500,000.

Beikman, H.M., compiler, 1980, Geologic map of Alaska: U.S. Geological Survey Special Map, scale 1:2,500,000, 2 sheets.

Burk, C.A., 1965, Geology of the Alaska Peninsula-island arc and continental margin: Geological Society of America Memoir 99, $250 \mathrm{p}$.

Detterman, R,L., Case, J.E., Miller, J.W., Wilson, F.H., and Yount, M.E., in press, Stratigraphic framework of the Alaska Peninsula: U.S. Geological Survey Bulletin 1969A.

Detterman, R.L., Case, J.E., Wilson, F.H., and Yount, M.E., 1987, Geologic map of the Ugashik, Bristol Bay, and western part of the Karluk quadrangles, Alaska: U.S. Geological Survey Miscellaneous Investigations Series Map I-1685, scale 1:250,000.

Detterman, R.L., Case, J.E., Wilson, F.H., Yount, M.E., and Allaway, W.H., 1983, Generalized geologic map of the Ugashik, Bristol Bay, and part of Karluk quadrangles, Alaska: U.S. Geological Survey Miscellaneous Field Studies Map MF-1539-A, scale $1: 250,000$.

Detterman, R.L., Miller, T.P., Yount, M.E., and Wilson, F.H., 1981, Geologic map of the Chignik and Sutwik Island quadrangles,
Alaska: U.S. Geological Survey Miscellaneous Investigations Series Map I-1229, scale 1:250,000.

Flett, T.O , 1988, Organic geochemistry, in Turner, R.F., ed., Geological and operational summary, North Aleutian Shelf COST No. 1 well, Bering Sea, Alaska: Minerals Management Service OCS Report MMS 88-0089, p. 184-202.

Hillhouse, J.W., 1987, Accretion of southern Alaska: Tectonophysics, v. 138 , p. $107-122$.

Johnsson, M.J., Pawlewicz, M.J., Harris, A.G., and Valin, Z.C., 1992, Vitrinite reflectance and conodont color alteration index data from Alaska: Data to accompany the thermal maturity map of Alaska: U.S. Geological Survey Open-File Report 92-409, three 3.5 inch, high-density Macintosh discs.

Magoon, L.B., and Anders, D.E., 1992, Oil-to-source-rock correlation using carbon-isotope data and biological marker compounds, Cook Inlet-Alaska Peninsula, Alaska, in Moldowan, J.M., Albrecht, Pierre, and Philp, R.P., eds., Biological markers in sediments and petroleum: Hertfordshire, England, Prentice-Hall, p. 241-279.

McLean, Hugh, 1977, Organic geochemistry, lithology, and paleontology of Tertiary and Mesozoic rocks from wells on the Alaska Peninsula: U.S. Geological Survey Open-File Report 77-813, $63 \mathrm{p}$.

Merritt, R.D., and McGee, D.L., 1986, Depositional environments and resource potential of Cretaceous coal-bearing strata at Chignik and Herendeen Bay, Alaska Peninsula: Sedimentary Geology, v. 49, p. 21-49.

Peters, K.E., 1986, Guidelines for evaluating petroleum source rocks using programmed pyrolysis: American Association of Petroleum Geologists Bulletin, v. 70, no. 3, p. 318-329.

Riehle, J.R., Detterman, R.L., Yount, M.E., and Miller, J.W., 1987, Preliminary geologic map of the Mt. Katmai quadrangle and portions of the Afognak and Naknek quadrangles, Alaska: U.S. Geological Survey Open-File Report 87-593, scale 1:250,000.

Wilson, F. H., Case, J. E., and Detterman, R. L., 1985, Preliminary description of a Miocene zone of structural complexity, Port Moller and Stepovak Bay quadrangles, in Bartsch-Winkler, S., and Reed, K. M., eds., The United States Geological Survey in Alaska: Accomplishments during 1983, U.S. Geological Survey Circular 945, p. 54-56.

Wilson, F.H., Detterman, R.L., and Harris, E.E., 1991, Generalized geologic map of the Port Moller, Stepovak Bay, and Simeonof Island quadrangles, Alaska Peninsula, Alaska: U.S. Geological Survey Miscellaneous Field Studies Map MF 2155-A, scale $1: 250,000$.

Wang, Jason, Newton, C.R., and Dunne, Lorrie, 1988, Late Triassic transition from biogenic to arc sedimentation on the Peninsula terrane, Puale Bay, Alaska Peninsula: Geologic Society of America Bulletin, v. 100, no. 9, p. 1466-1478. 


\title{
THERMAL EVOLUTION OF SEDIMENTARY BASINS IN ALASKA
}

U.S. Geological Survey Bulletin 2142

\section{Heat Flow and Subsurface Temperature, North Slope of Alaska}

\author{
By David Deming ${ }^{1}$, John H. Sass ${ }^{2}$, and Arthur H. Lachenbruch ${ }^{3}$
}

\section{CONTENTS}

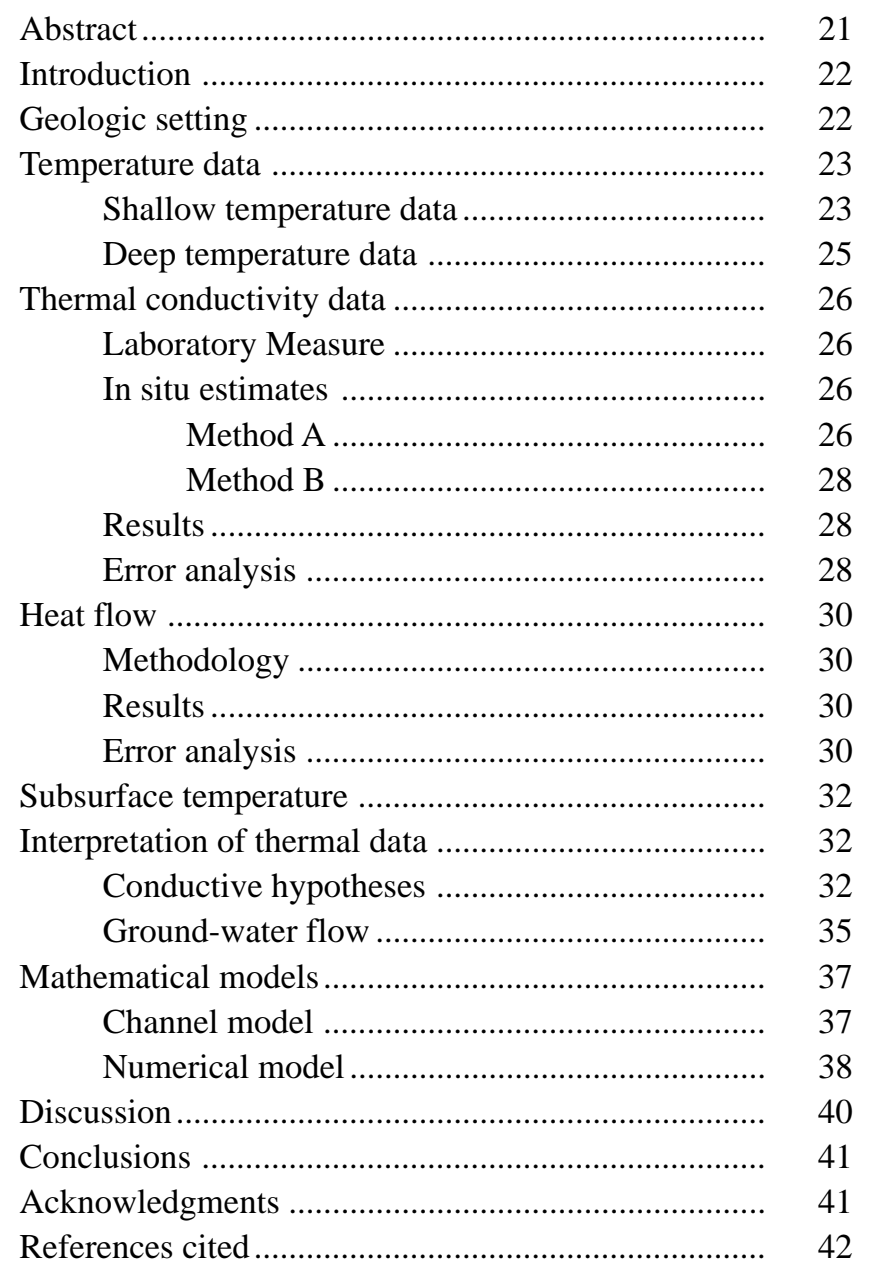

${ }^{1}$ School of Geology and Geophysics, University of Oklahoma, Norman, OK 73019-0628.

${ }^{2}$ U.S. Geological Survey, 2255 North Gemini Dr., Flagstaff, AZ 86001.

${ }^{3}$ U.S. Geological Survey, 345 Middlefield Road, Mail Stop 923, Menlo Park, CA 94025
In conjunction with the U.S. Geological Survey's exploration program in the National Petroleum Reserve in Alaska (NPRA) several high-resolution temperature logs were made in each of 21 drillholes between 1977 and 1984. These time-series of shallow (average $600 \mathrm{~m}$ depth) temperature profiles were extrapolated to infinite time to yield equilibrium temperature profiles $\left( \pm 0.1^{\circ} \mathrm{C}\right)$. Thermal gradients were found to be inversely correlated with elevation and varied from $22^{\circ} \mathrm{C} / \mathrm{km}$ in the foothills of the Brooks Range to as high as $53^{\circ} \mathrm{C} / \mathrm{km}$ on the coastal plain to the north. Shallow temperature data were supplemented with 24 equilibrium temperatures $\left( \pm 3\right.$ to $\left.5^{\circ} \mathrm{C}\right)$ estimated from bottom-hole temperatures (BHT's) series measured near the bottom of petroleum exploration wells at depths ranging from $\sim 1$ to $6 \mathrm{~km}$. A total of 601 thermal conductivity measurements were made on drill cuttings and cores. Like the thermal gradients, near-surface heat flow ( \pm 20 percent) was found to be inversely correlated with elevation and ranged from a low of $27\left(\mathrm{~mW} / \mathrm{m}^{2}\right)$ in the foothills of the Brooks Range in the south to a high of 90 $\mathrm{mW} / \mathrm{m}^{2}$ near the north coast of Alaska. Subsurface temperatures and thermal gradients estimated from corrected BHT's were similarly much higher on the Arctic coastal plain than in the Brooks Range foothills province to the south. Significant east-west variation in heat flow and subsurface temperature was also observed; higher heat flow and temperature coincided with higher basement topography. The observed thermal pattern was consistent with forced convection by a topographically driven ground-water-flow system; alternative explanations were largely unsatisfactory. Average groundwater velocity (Darcy) in the postulated flow system was estimated to be on the order of $0.1 \mathrm{~m} / \mathrm{yr}$; the effective basinscale permeability parallel to bedding was estimated to be on the order of $10^{-14} \mathrm{~m}^{2}$. Organic-maturation data collected in other studies indicated that systematic variations in thermal state may have persisted for tens of millions of years. The ground-water-flow system thought to be responsible for present heat-flow variations conceivably has existed for the same period of time, possibly providing the driving mechanism for petroleum migration and accumulation at Prudhoe Bay. 


\section{INTRODUCTION}

The thermal history of a sedimentary basin is of interest for several reasons. Nearly all chemical reactions involved in the diagenesis of sedimentary rocks are temperature dependent. For example, the generation of oil and gas from organic matter has an exponential dependence on temperature (Tissot and others, 1987), and diagenetic processes involving the solution, deposition, replacement, recrystallization, and cementation of common minerals in sedimentary rocks all depend on temperature. The thermal state of the lithosphere also determines its flexure and thereby affects the morphology and structural evolution of all sedimentary basins. Thus, an understanding of the thermal history of a sedimentary basin is essential to obtaining an understanding of the chemical and physical evolution of rocks within a basin, as well as the development of basin structure and form through time (Deming, 1994a).

The thermal history of a sedimentary basin is described by the chronology of thermal parameters such as temperature, geothermal gradient, or heat flow. Geothermal gradient and heat flow are related through the process of heat conduction as described by Fourier's law,

$$
q=\lambda \gamma
$$

where $q$ is conductive heat flow, $\lambda$ is thermal conductivity, and $\gamma$ is the thermal gradient. Fourier's law holds true even in the presence of nonconductive heat transport (for example, fluid movement), if $q$ is understood to be conductive heat flow and not the total energy transport due to all physical processes. On a point-wise basis, Fourier's law also holds true for rapidly changing thermal fields; steady-state conditions are not required.

From equation (1) it follows that the quantity usually determined from field measurements of subsurface temperature (the geothermal gradient) depends on both heat flow and thermal conductivity. However, the thermal conductivity of common sedimentary lithologies may easily vary by a factor of three; appreciable lateral and vertical variations in thermal gradients may simply reflect changes in sedimentary facies that are unrelated to heat-transport processes within a basin. In contrast, heat flow must be vertically and laterally continuous throughout a sedimentary basin, unless there are appreciable changes in heat sources or sinks or transient disturbances due to factors such as rapid sedimentation or erosion. It follows that lateral and vertical variations in heat flow may reveal the presence of factors such as variations in the concentration of radioactive heat-generating elements in the crust or processes such as heat transport by fluid movement.

Subsidence on the North Slope of Alaska has long since ceased, and the region has undergone a considerable amount of erosion and uplift since the time of maximum sediment accumulation. The composite structure of the North Slope consists of an older sequence of Paleozoic and Mesozoic rocks
(Ellesmerian sequence) laid down in a passive-margin setting ( $\sim 350$ to $115 \mathrm{Ma}$ ) that is overlain by younger foreland basin deposits deposited during the Brookian orogeny $(\sim 120$ to $50 \mathrm{Ma}$ ). Maximum sediment thickness and burial occurred at $\sim 75 \mathrm{Ma}$; erosion has dominated since that time, with the total amount of removed section increasing southward from the Arctic coastline toward the Brooks Range. Bird (1993) estimated the total section removed by erosion in the foothills of the Brooks Range near the Awuna well to be approximately $3 \mathrm{~km}$, decreasing to $300 \mathrm{~m}$ at the Inigok well on the Arctic coastal plain, with near zero erosion at Prudhoe Bay. Thus, most rocks in the foothills province of the North Slope were probably exposed to maximum temperatures at $\sim 75 \mathrm{Ma}$, and the maturity level of organic material found in these rocks is probably indicative of thermal conditions prevailing at that time. Consideration of the burial history of the North Slope thus suggests that there are two convenient points in time from which data may be obtained to constrain the thermal history of the basin. The first of these points in time is the time of maximum burial and the second is the present day, which is the only time at which temperature in the basin can be measured directly rather than inferred from paleothermal indicators.

In this paper we present temperature and thermal-conductivity data from the North Slope and combine these data in order to estimate present-day heat flow at 21 sites throughout the region. Estimation of the present thermal state in the North Slope forms a basis for extending the analysis of the thermal state into the past; any thermal history that is ultimately derived must be consistent not only with paleotemperatures inferred from geothermometers, such as vitrinite reflectance or fluid inclusions, but also the presentday thermal state.

\section{GEOLOGIC SETTING}

In this section we briefly review aspects of North Slope geology relevant to our thermal analyses. Summaries of the regional geology and physiography of the Alaskan North Slope were given by Bird (1987, 1988, 1991a, b, 1992, 1993) and in volumes edited by Tailleur and Weimer (1987) and Gryc (1988). Bird (1987, p. 121) cited a comprehensive list of references. The following discussion is after Bird (1987, 1991b).

The North Slope of Alaska lies between the Brooks Range to the south and Arctic Ocean coastline to the north (fig. 1). Rocks on the North Slope can be divided into two main sequences, the (lower) Ellesmerian sequence and (upper) Brookian sequence (fig. 2). From Mississippian to Early Cretaceous time, Ellesmerian sediments were derived from a northern (in present-day coordinates) source area and deposited in a passive margin setting. Rifting during Jurassic and earliest Cretaceous time created an oceanic basin to the north and basement uplift which formed the Barrow Arch (fig. 3). 
Orogenesis beginning in the Late Jurassic led to deposition of the younger Brookian sequence as a thick wedge of clastic sediments shed from the ancestral Brooks Range in the south and deposited in the adjacent Colville basin to the north.

In basins with active fluid-flow systems, the topography of the sediment-basement contact can influence directions of fluid movement and concomitant heat transport (Garven and Freeze, 1984). Even though the structural grain of the North Slope trends east-west, significant variation of basement topography exists along strike (fig. 4). A thick section of Ellesmerian rocks occupies the Ikpikpuk-Umiat basin, essentially forming a basin within a basin. The Meade Arch to the west and Fish Creek Platform to the east (fig. 4) of this basin are structural highs that developed during deposition of the Ellesmerian sequence (Bird, 1987).

Because mean annual sea water temperatures in the Arctic Ocean are about $10^{\circ} \mathrm{C}$ higher than mean annual air temperatures near the coast, a transgressive event can, like a rapid climate change, have substantial effects on the thermal regime of boreholes (Lachenbruch, 1957). A series of marine transgressions have inundated the Alaskan north coast during the last 3.5 m.y. (Carter and others, 1986). Estimates of maximum landward elevations reached by the advancing shoreline during these transgressions range from 7 to $60 \mathrm{~m}$ above present sea level. Geomorphic analyses of the Alaskan north coast east of Point Barrow (fig. 1) indicate that today the Arctic Ocean is again rapidly transgressing onto the land there at rates greater than $1 \mathrm{~m} / \mathrm{yr}$ (Hopkins and Hartz, 1978).

\section{TEMPERATURE DATA}

\section{SHALLOW TEMPERATURE DATA}

As part of the 1974 to 1982 U.S. Geological Survey exploration program in the National Petroleum Reserve in Alaska (NPRA), 28 deep (1 to $6 \mathrm{~km}$ ) wells were drilled. A description of the NPRA exploration program along with more detailed information on the drilling of individual wells may be found in the volume edited by Gryc (1988). Following the cessation of drilling, the upper cased parts of 21 of these wells were filled with diesel fuel to prevent freezing and to allow subsequent reentry for temperature logging. Repeated temperature measurements were made in these wells from 1977 to 1984. Details of the measurement procedures and instrumentation were given by Lachenbruch and others (1987, 1988). Equilibrium temperatures were estimated by extrapolating the thermal recovery of these boreholes to infinite time using a line source model (Bullard, 1947; Lachenbruch and Brewer, 1959). We estimate that the accuracy of these equilibrium temperature profiles (fig. 5) is $\pm 0.1^{\circ} \mathrm{C}$. The geothermal gradients shown in figure 5 can be extrapolated to the surface to estimate the long-term mean annual surface temperature. Estimated surface temperatures $\left( \pm 0.5^{\circ} \mathrm{C}\right)$ range from about $-12^{\circ} \mathrm{C}$ on the Alaskan north coast to $-6^{\circ} \mathrm{C}$ at well LBN (fig. 1), the southernmost well in the foothills of the Brooks

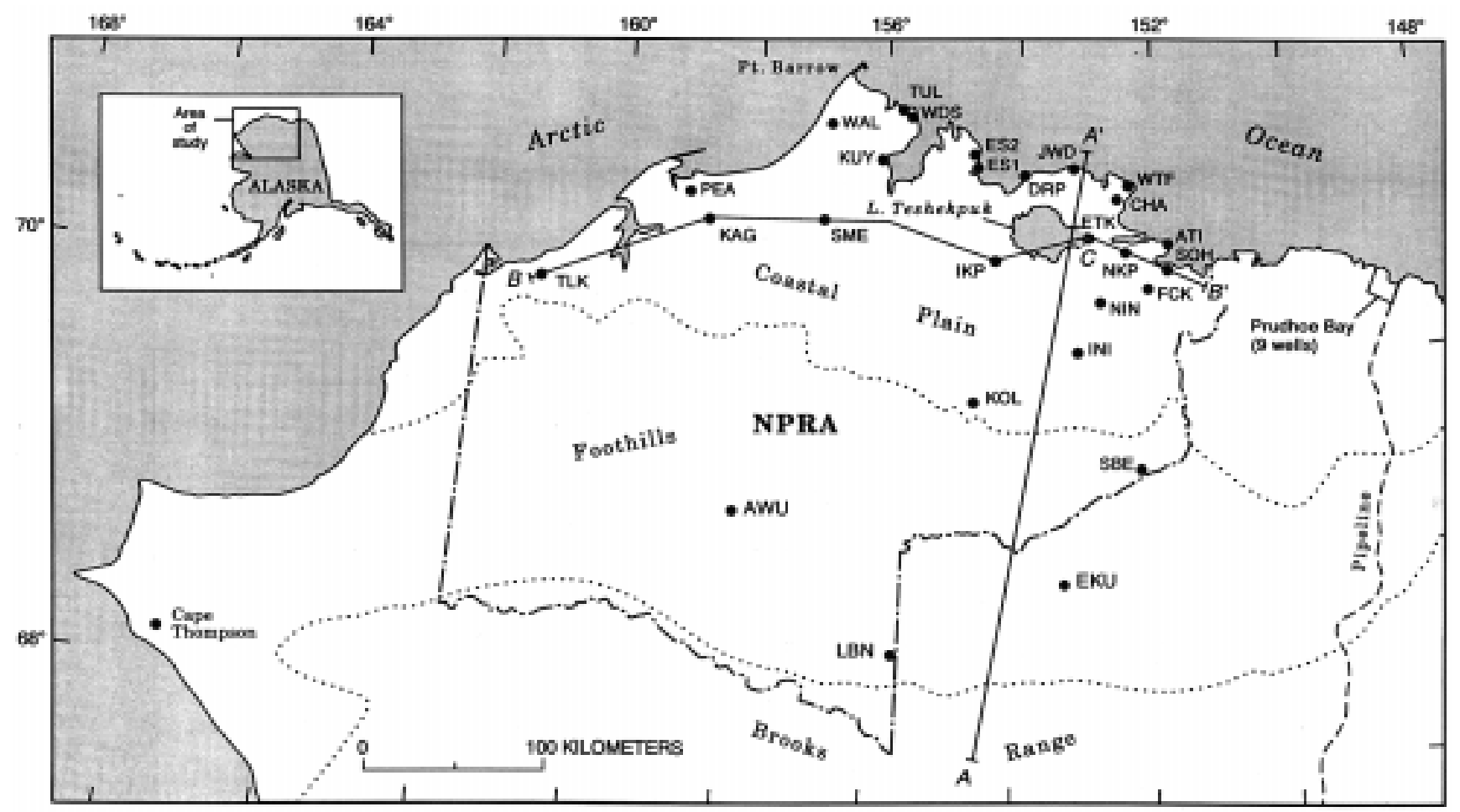

Figure 1. Location map of North Slope of Alaska showing well locations (modified from Bird, 1987). Cross sections A-A' and B-B' are shown in figures 3 and 4, respectively. Dotted lines indicate boundaries of physiographic provinces (Brooks Range, foothills, and coastal plain). Well names are given in table 3 . 
Range (Lachenbruch and others, 1987, 1988). Significant curvature of the temperature profile in the upper $100 \mathrm{~m}$ of several of the drillholes is present, although not apparent on the scale shown in fig. 5. This curvature is believed to represent a climatic warming of 2 to $4^{\circ} \mathrm{C}$ over the last century (Lachenbruch and Marshall, 1986). Average thermal gradients (fig. 5) range from $22^{\circ} \mathrm{C} / \mathrm{km}$ in well $\mathrm{LBN}$ to $53^{\circ} \mathrm{C} / \mathrm{km}$ in well NKP. Segregation of thermal profiles (fig. 5) illus- trates the contrast between lower gradients in the foothills and higher gradients on the coastal plain. Lachenbruch and others $(1987,1988)$ showed thermal profiles from an additional five wells located in the foothills of the Brooks Range which were not used in this study owing to a lack of thermal-conductivity data. These profiles also exhibit much lower thermal gradients than their counterparts on the coastal plain.

\begin{tabular}{|c|c|c|}
\hline AGE & LITHOLOGY & UNIT \\
\hline QUATERNARY Ma & & Gubik Fm and surficial deposits \\
\hline TERTIARY & & $\begin{array}{c}\text { Sagavanirktok Fm. } \\
\text { and Colville Group (sandstone) }\end{array}$ \\
\hline $\begin{array}{c}\text { LATE } \\
\text { CRETACEOUS }\end{array}$ & & $\begin{array}{l}\text { Canning Fm. and } \\
\text { Colville Group (shale) }\end{array}$ \\
\hline \multirow{3}{*}{$\begin{array}{c}\text { EARLY } \\
\text { CRETACEOUS }\end{array}$} & & Nanushuk Group \\
\hline & & Torok Fm. \\
\hline & & $\begin{array}{c}\text { Pebbble shale unit } \\
\text { Kuparuk Fm. }\end{array}$ \\
\hline JURASSIC & \multirow{4}{*}{ 等 } & Kingak Shale \\
\hline \multirow{3}{*}{ TRIASSIC } & & Sag River Sandstone \\
\hline & & Shublik Fm. \\
\hline & & Sadlerochit Group \\
\hline \multicolumn{3}{|l|}{ PERMIAN } \\
\hline \multirow{2}{*}{\begin{tabular}{|l} 
PENNSYLVANIAN \\
MISSISSIPPIAN
\end{tabular}} & & Lisburne Group \\
\hline & & Endicott Group \\
\hline $\begin{array}{l}\text { PRE- } \\
\text { MISSISSIPPIAN }\end{array}$ & $y_{+}^{+}+2$ & Basement complex \\
\hline $\begin{array}{c}\text { Sandstone } \\
\text { or } \\
\begin{array}{c}\text { orglom- } \\
\text { erate }\end{array}\end{array}$ & $\begin{array}{l}\text { imestone } \\
\text { or } \\
\text { olomite }\end{array}$ & $\begin{array}{c}\text { e or } \\
\text { tone }\end{array}$ Argillite $+\underset{+}{\text { Granitic }}$ rocks \\
\hline
\end{tabular}

Figure 2. Stratigraphic column for North Slope of Alaska (after Bird, 1987). SW, southwest; NE, northeast. 


\section{DEEP TEMPERATURE DATA}

In addition to continuous, high-precision temperature logs measured in the upper sections of NPRA drill holes, we also used bottom-hole temperatures (BHT's) measured near the bottom of these same holes during geophysical logging (table 1). These temperature data were collected and corrected by Blanchard and Tailleur (1982). Correction was done by means of a line source model, identical to that used to estimate the shallow equilibrium temperature profiles. This procedure is commonly known as a Horner plot when applied to BHT data. Uncertainties and pitfalls involved in working with BHT's were discussed by Blanchard and Tailleur (1982); more generalized and comprehensive discussions are given by Luheshi (1983), Shen and Beck (1986), and Deming (1989).

Because detailed records of drilling operations were kept for USGS exploration wells, the duration of circulation at the bottom of these wells is known. This information is required to estimate equilibrium temperatures but is frequently not available. In other studies (Chapman and others, 1984; Deming and Chapman,
1988), this difficulty was circumvented by assuming a standard bottom-hole circulation time of about 5 hours for all wells. Unfortunately, perhaps because of extensive coring operations, many of the circulation periods for NPRA wells were quite lengthy, with some periods in the hundreds of hours. Because the line source model is unreliable until a well has been shut in for a period of time at least as long as the original circulation period (Lachenbruch and Brewer, 1959; Shen and Beck, 1986), we used only data from wells that had two or more BHT's satisfying this condition. We estimate that the average uncertainty of these equilibrium temperatures was about $\pm 3^{\circ} \mathrm{C}$, although large errors may have been possible in individual cases. To obtain additional control over deep temperature in the foothills of the Brooks Range, the temperature data of Blanchard and Tailleur (1982) were supplemented by BHT's from well EKU, located just to the east of the NPRA (fig. 1). Two BHT's of 67 and $69^{\circ} \mathrm{C}$, measured at shut in times of 6 and 9 hours, respectively, were used to estimate an equilibrium temperature of 75 $( \pm 5)^{\circ} \mathrm{C}$ by assuming a circulation time of 5 hours.

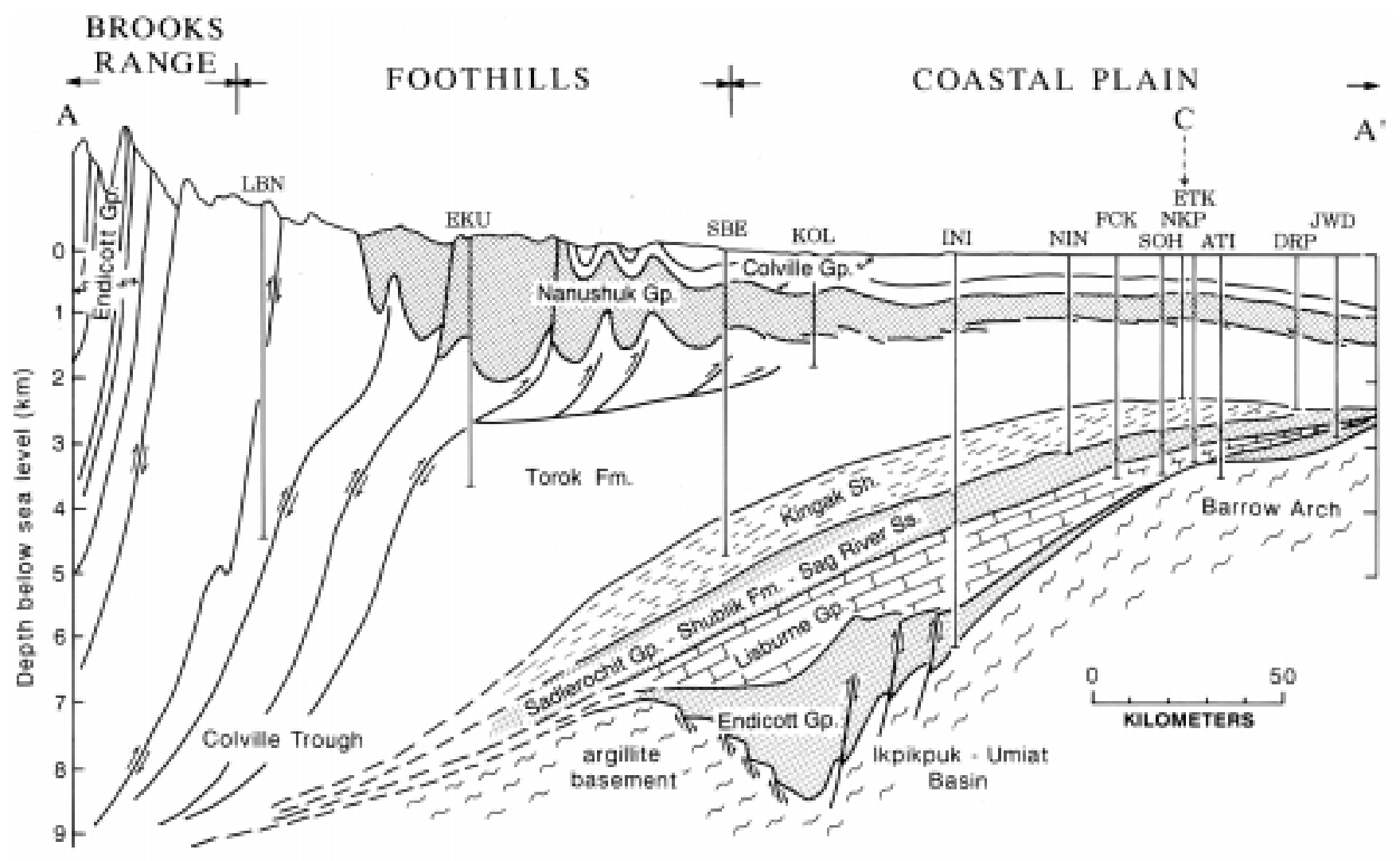

Figure 3. North-south cross section A-A' shown on figure 1 (after Bird, 1991b). Borehole locations are projected onto cross section; thus, actual depth to formation tops in individual wells may differ from position of formation boundaries shown on cross section. Lithologic units are those shown on figure 2; well names are given in table 3. 


\section{THERMAL CONDUCTIVITY DATA}

\section{LABORATORY MEASUREMENTS}

Measurements were made on drill chips and cores obtained from NPRA wells shown in figure 1. Of the 601 total measurements, 434 were made on drill chips using the cell method of Sass and others (1971), 100 were made on core samples using needle probes (Sass, Kennelly, and others, 1984), and 67 were made on core samples using a dividedbar apparatus (Sass, Stone, and Munroe, 1984). All measurements were made at $25^{\circ} \mathrm{C}$. Measurements on drill chips yield estimates of the solid matrix component of a porous rock. To allow meaningful comparisons, divided-bar and needle-probe measurements on water-saturated core samples were converted to matrix conductivities using a geometric-mean model. Measurements are summarized in table 2.

Average anisotropies ( $a$ ) (table 2 ) were estimated from 54 paired needle-probe measurements as:

$$
a=\lambda_{x y} / \lambda_{z}
$$

where $\lambda_{x y}$ is the thermal conductivity parallel to bedding, and $\lambda_{z}$ is the inferred conductivity perpendicular to bedding. The inferred conductivity perpendicular to bedding $\left(\lambda_{z}\right)$ was calculated according to Grubbe and others (1983):

$$
\lambda_{z}=\left(\lambda_{x y z}^{2} / \lambda_{x y}\right)
$$

where $\lambda_{x y}$ is measured by inserting a needle probe so that the long axis of the probe is perpendicular to bedding, and $\lambda_{x y z}$ is measured by inserting a needle probe into the side of a core with the long axis parallel to bedding.

\section{IN SITU ESTIMATES}

\section{METHOD A}

In 16 instances we had both equilibrium-temperature logs and thermal-conductivity measurements (almost entirely on drill chips) made over the same depth intervals from the same wells. In these cases we estimated in situ thermal conductivity in the following manner. Laboratory measurements were corrected for anisotropy, and in situ conductivity was calculated for each sample interval (typically about $10 \mathrm{~m}$ ) using a geometric-mean model (see more recent work by Deming, 1994b). Anisotropy corrections were done by as-

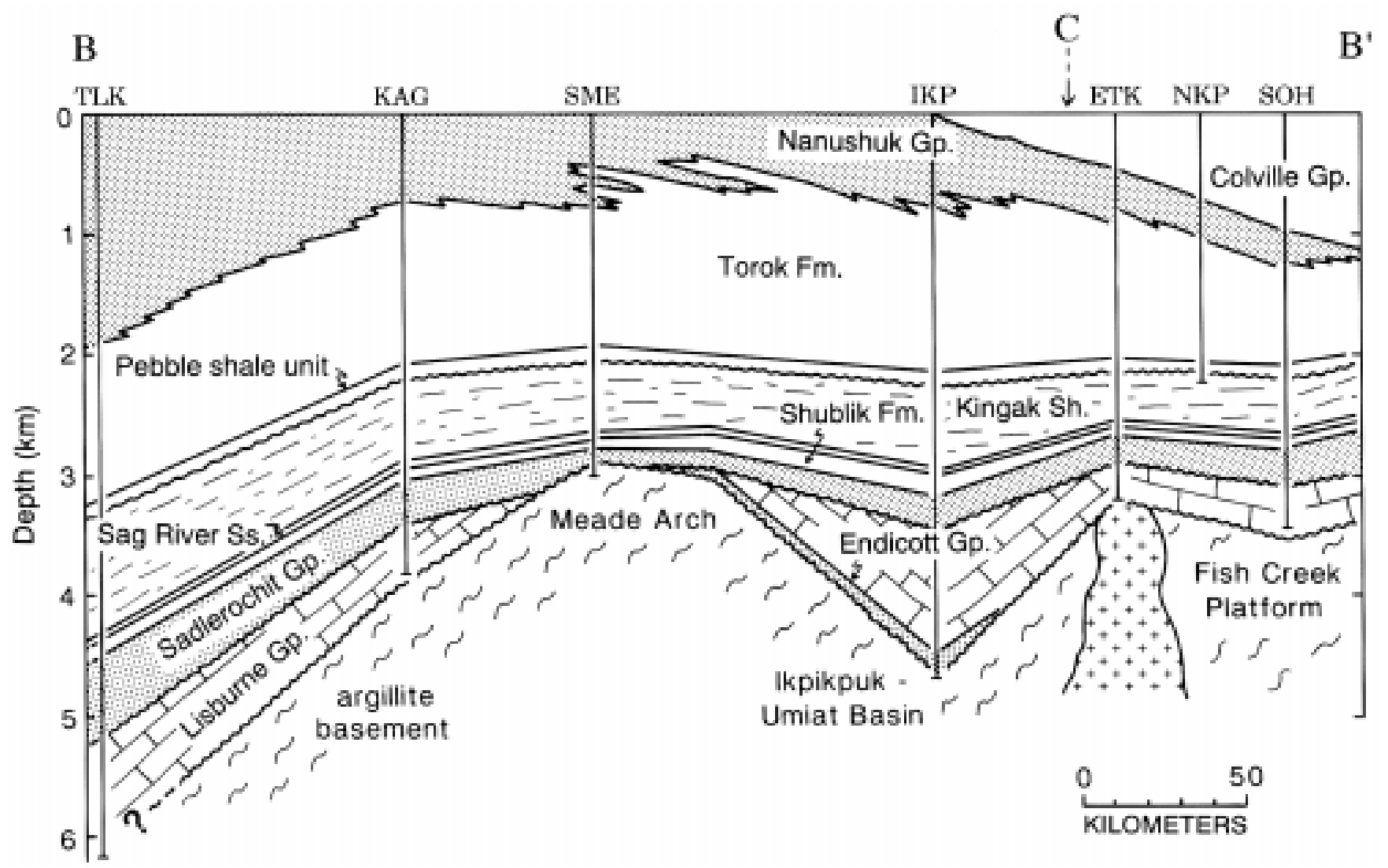

Figure 4. East-west cross section B-B' shown on figure 1 (after Molenaar and others, 1986). Lithologic units are those shown on figure 2; well names are given in table 3. 
suming that one-third of the matrix grains in cell holders were oriented in a direction perpendicular to original bedding $\left(\lambda_{z}\right)$ and that two-thirds were oriented in directions parallel to the original bedding $\left(\lambda_{x y}\right)$. The vertical matrix conductivity was then estimated using a geometric-mean model; for example

$$
\lambda_{z}=\lambda_{a} / a^{2 / 3}
$$

where $\lambda_{a}$ is the matrix conductivity of the entire aggregate in the cell holder, and $a$ is the average formation anisotropy (table 2). Anisotropy values determined from needle-probe measurements were found to be inversely correlated with conductivity; thus, no anisotropy corrections were applied to samples with matrix conductivities greater than $3.0(\mathrm{~W} / \mathrm{m} \cdot \mathrm{K})$. No temperature corrections were applied to the inferred matrix conductivities (table 2).

Rock pores in the upper few hundred meters of NPRA wells may be saturated with either water or ice, depending on the temperature and freezing point of the pore fluid. In certain instances, it is possible to determine the location of the ice/water interface from a series of temperature logs made at different times (Lachenbruch and others, 1982). This is possible because of a lag in the return to thermal equilibrium associated with the latent heat of water. For most of the NPRA boreholes in this study, however, the ice/water interface could not be defined precisely. Therefore, we applied the following conservative assumptions in all cases: (1) All intervals with equilibrium temperatures colder than $-5^{\circ} \mathrm{C}$ were assumed to be saturated with ice, and (2) intervals with equilibrium temperatures greater than $0^{\circ} \mathrm{C}$ were assumed to be water saturated. Intervals with equilibrium temperatures in the range -5 to $0^{\circ} \mathrm{C}$ were omitted from heat-flow calculations. We used a value of $2.28 \mathrm{~W} / \mathrm{m} \cdot \mathrm{K}$ for the thermal conductivity of ice (Kappelmeyer and Haenel, 1974, p. 222) and calculated the thermal conductivity of water (about $0.6 \mathrm{~W} / \mathrm{m} \cdot \mathrm{K}$ ) as a function of temperature (Touloukian and others, 1970). We used an average porosity of 20 percent for the upper part $(<1 \mathrm{~km}$ depth) of all NPRA boreholes; this average value was estimated from available density and neutron logs. Our estimate of an average porosity is poorly constrained, but considering other uncertainties (see below), further refinement of this simple assumption is probably not warranted.

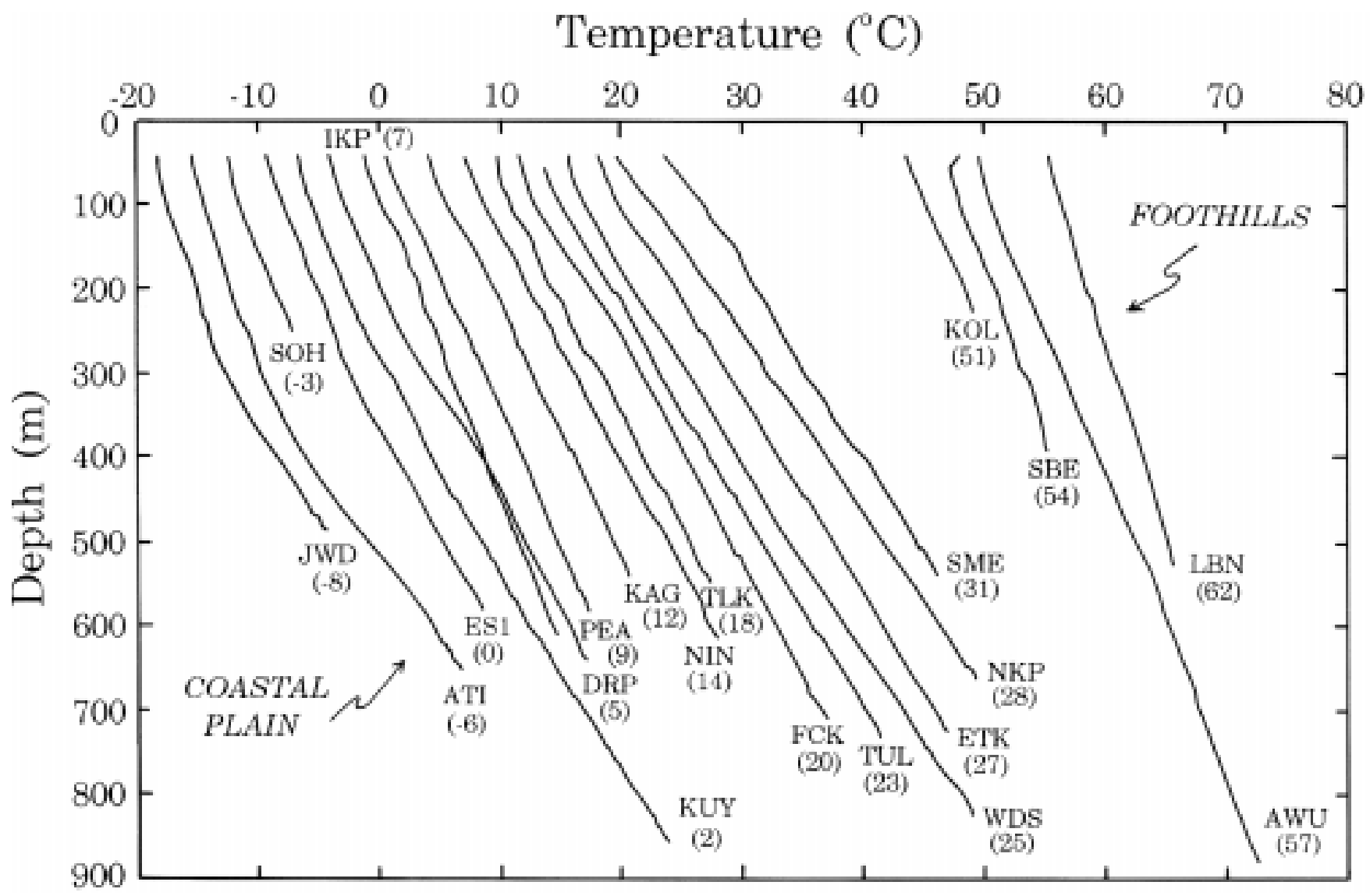

Figure 5. Equilibrium-temperature profiles (after Lachenbruch and others, 1988). Numbers in parentheses indicate offsets of temperature profiles from origin in degrees Celsius. Well locations are shown on figure 1; well names are given in table 3. 
Table 1. Bottom-hole temperature data.

[See table 3 and figure 1 for well names and locations. Leaders (- -), not determined]

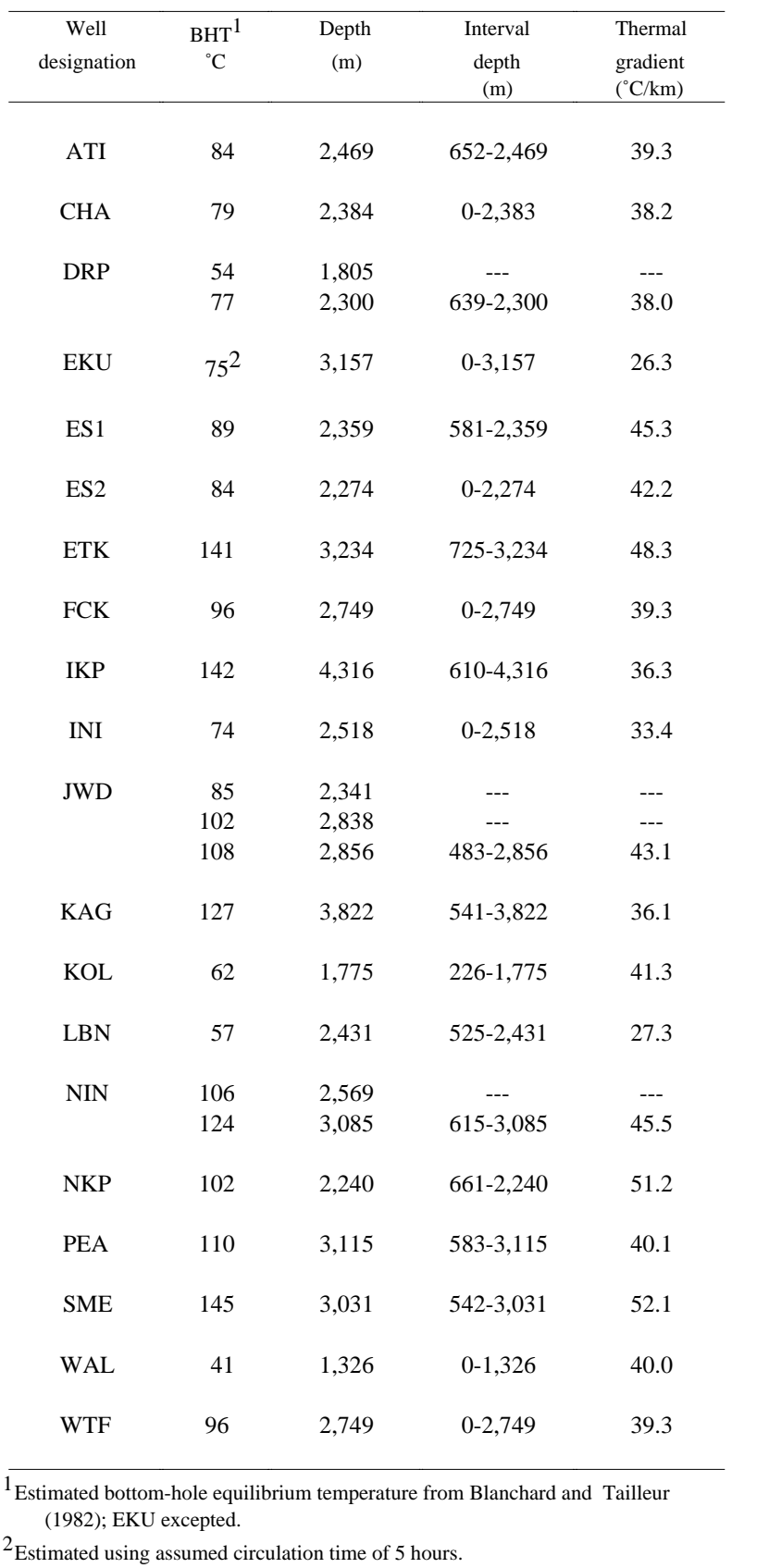

\section{METHOD B}

For 5 of the 21 NPRA wells listed in table 2 (ES1, KOL, KUY, NIN, and TUL), we had shallow and continuous estimates of equilibrium temperature (fig. 5) but no thermal conductivity data. In these cases, we estimated in situ thermal conductivity from averages for geologic units (table 2), while correcting for estimated porosity as in method (A) above.

\section{RESULTS}

Taken as a whole, the North Slope sequence tends to be shale rich, and therefore the average thermal conductivity is fairly low and anisotropic. Brookian sequence units (Colville Group, Nanushuk Group, and Torok Formation), which make up the upper part of the North Slope sequence, tend to have low thermal conductivities. A typical in situ thermal-conductivity value for the Torok Formation (which constitutes a large part of the North Slope sequence) is $1.7 \mathrm{~W} / \mathrm{m} \cdot \mathrm{K}$. Ellesmerian sequence rocks have somewhat higher thermal conductivities, but the average matrix conductivities given in table 2 are lowered by both temperature effects and porosity. The average matrix conductivity $\left(25^{\circ} \mathrm{C}\right)$ of the Lisburne Group is $3.7 \mathrm{~W} / \mathrm{m} \cdot \mathrm{K}$, but a typical in situ estimate is about $2.9 \mathrm{~W} / \mathrm{m} \cdot \mathrm{K}$, which is 22 percent lower. The average matrix conductivity $\left(25^{\circ} \mathrm{C}\right)$ of the Sag River Sandstone is relatively high $(4.1 \mathrm{~W} /$ $\mathrm{m} \cdot \mathrm{K}$ ), but this unit is too thin (fig. 4) to appreciably affect the net thermal resistance of the basin.

\section{ERROR ANALYSIS}

Sources of error are varied, both for the measurement of thermal-conductivity values in the laboratory and the estimation of in situ thermal-conductivity values (see discussions in Deming and Chapman, 1988; Blackwell and Steele, 1989; Sass and others, 1992). The inherent accuracy of measuring devices (divided bar or needle probe) is usually about \pm 5 to 10 percent. Removal of rocks from in situ conditions may change their thermal conductivities, although laboratory samples are usually saturated with water prior to measurement. In the case of measurements on drill chips, sample bias can be a potentially serious problem, and data reduction relies on an interpretive model (such as a geometric-mean model) to account for the contribution of pore fluid and assumptions regarding porosity and anisotropy of the intact rock. These factors may introduce errors of \pm 10 to 15 percent. Following the determination of laboratory thermal-conductivity values, corrections may subsequently be required for the estimation of in situ temperature and porosity. Thus, estimation of in situ values from laboratory measurements is likely to introduce additional uncertainties. However, these factors are mitigated by redundancy in the data that averages and thus reduces random errors. As a general rule of thumb, a practical upper limit to the best accuracy that can be obtained for divided-bar or needle-probe measurements on core samples is about \pm 10 percent; in exceptional circumstances, this may be \pm 5 percent. For drill chips, the best accuracy that can be achieved is about \pm 10 to 15 percent (Deming, Nunn, Jones, and Chapman, 1990).

In this study, we have many drill chip samples for the upper parts of 15 of 21 NPRA wells, but our estimates of in situ thermal conductivity (method A) are largely dependent on our assumptions regarding in situ porosity (20 percent) and anisotropy (1.2). The maximum error that these assumptions are likely to introduce is probably about \pm 20 percent. For example, if we consider a matrix conductivity of $2.0 \mathrm{~W} /$ 
Table 2. Thermal conductivity data.

[See figure 2 for unit descriptions. Leaders (- - -), not determined]

\begin{tabular}{|c|c|c|c|c|c|c|c|}
\hline $\begin{array}{c}\text { Geologic } \\
\text { unit }\end{array}$ & $\begin{array}{c}\text { Measurement } \\
\text { type }^{1}\end{array}$ & $\mathrm{~N}^{2}$ & $\begin{array}{c}\text { Matrix } \\
\text { conductivity } \\
\text { (W/m-K) } \\
\end{array}$ & $\begin{array}{c}\text { Standard } \\
\text { deviation }^{4} \\
(\mathrm{~W} / \mathrm{m}-\mathrm{K})\end{array}$ & $\begin{array}{c}\text { Standard } \\
\text { error }^{5} \\
(\mathrm{~W} / \mathrm{m}-\mathrm{K}) \\
\end{array}$ & $\mathrm{N}^{6}$ & $\begin{array}{c}\text { Anisotropy (a) } \\
\lambda_{\mathrm{xy}} / \lambda_{\mathrm{z}}\end{array}$ \\
\hline Colville Gp. & $\mathrm{C}$ & 113 & 2.31 & 1.04 & 0.10 & --- & $(1.2)^{7}$ \\
\hline \multirow[t]{4}{*}{ Nanushuk Gp. } & $\mathrm{C}$ & 245 & 1.71 & 1.00 & --- & --- & --- \\
\hline & $\mathrm{N}$ & 10 & 2.22 & 0.65 & --- & --- & --- \\
\hline & $\mathrm{D}$ & 8 & 2.84 & 0.75 & --- & --- & --- \\
\hline & Average & 263 & 1.75 & 0.99 & 0.06 & 4 & 1.2 \\
\hline \multirow[t]{4}{*}{ Torok Fm. } & $\mathrm{C}$ & 76 & 1.67 & 0.13 & --- & --- & --- \\
\hline & $\mathrm{N}$ & 30 & 1.82 & 0.47 & --- & --- & --- \\
\hline & D & 24 & 2.33 & 0.83 & --- & --- & --- \\
\hline & Average & 130 & 1.80 & 0.54 & 0.05 & 17 & 1.6 \\
\hline \multirow{4}{*}{$\begin{array}{l}\text { Pebble Shale } \\
\text { Unit }\end{array}$} & $\mathrm{N}$ & 21 & 1.69 & 0.70 & --- & --- & --- \\
\hline & & & & & & & \\
\hline & D & 2 & 1.15 & 0.03 & --- & --- & --- \\
\hline & Average & 23 & 1.62 & 0.70 & 0.15 & 12 & 1.6 \\
\hline Kuparuk Fm. & $\mathrm{N}$ & 1 & 2.50 & --- & --- & 1 & 1.3 \\
\hline \multirow[t]{3}{*}{ Kingak Sh. } & $\mathrm{N}$ & 11 & 2.10 & 1.14 & --- & --- & --- \\
\hline & D & 5 & 2.35 & 1.32 & --- & --- & --- \\
\hline & Average & 16 & 2.17 & 1.17 & 0.29 & 4 & 1.5 \\
\hline \multirow[t]{3}{*}{ Sag River Ss. } & $\mathrm{N}$ & 2 & 4.47 & 0.01 & --- & --- & --- \\
\hline & D & 3 & 3.93 & 0.64 & --- & --- & --- \\
\hline & Average & 5 & 4.13 & 0.52 & 0.23 & 1 & 1.1 \\
\hline \multirow[t]{3}{*}{ Shublik Fm. } & $\mathrm{N}$ & 4 & 2.49 & 0.29 & --- & --- & --- \\
\hline & $\mathrm{D}$ & 3 & 2.79 & 0.16 & --- & --- & --- \\
\hline & Average & 7 & 2.61 & 0.27 & 0.10 & 2 & 1.3 \\
\hline \multirow[t]{3}{*}{ Sadlerochit Gp. } & $\mathrm{N}$ & 12 & 2.43 & 0.80 & --- & --- & --- \\
\hline & D & 6 & 5.15 & 0.49 & --- & --- & --- \\
\hline & Average & 18 & 2.95 & 1.44 & 0.34 & 6 & 1.6 \\
\hline \multirow[t]{3}{*}{ Lisburne Gp. } & $\mathrm{N}$ & 3 & 2.73 & 0.72 & --- & --- & --- \\
\hline & $\mathrm{D}$ & 11 & 4.11 & 1.63 & --- & --- & --- \\
\hline & Average & 14 & 3.71 & 1.65 & 0.44 & 2 & 1.3 \\
\hline \multirow[t]{3}{*}{ Endicott Gp. } & $\mathrm{N}$ & 1 & 2.87 & --- & --- & --- & --- \\
\hline & D & 2 & 6.43 & 0.48 & --- & --- & --- \\
\hline & Average & 3 & 4.55 & 2.09 & 1.21 & 1 & 1.1 \\
\hline \multirow{4}{*}{$\begin{array}{l}\text { Argillite } \\
\text { (basement rocks) }\end{array}$} & $\mathrm{N}$ & 5 & 2.67 & 0.74 & --- & --- & --- \\
\hline & $\mathrm{D}$ & 3 & 2.84 & 0.76 & --- & --- & --- \\
\hline & Average & 8 & 2.73 & 0.70 & 0.25 & 4 & 1.2 \\
\hline & & 8 & 2.73 & 0.70 & 0.25 & 4 & 1.2 \\
\hline
\end{tabular}

${ }^{1} \mathrm{C}$, chips/divided bar; $\mathrm{N}$, core/needle probe; $\mathrm{D}$, core/divided bar.

${ }^{2}$ Number of thermal conductivity measurements.

${ }^{3}$ Harmonic mean perpendicular to bedding, $25^{\circ} \mathrm{C}$, equal sample weighting.

${ }^{4}$ Standard Deviation from the arithmetic mean.

${ }^{5}$ Standard Error of the arithmetic mean.

${ }^{6}$ Number of paired needle-probe measurements used to estimate anisotropy.

$\mathrm{m} \cdot \mathrm{K}$, then the estimated conductivity does not vary by more than \pm 20 percent, if a porosity between 10 percent and 30 percent and an anisotropy factor $(a)$ between 1.0 and 1.4 are used. Conversely, consideration of the many other factors listed above suggests that it is prudent to consider that the probable error is no smaller than \pm 20 percent. Therefore, we estimate that the average error of in situ thermal-conductivity estimates made by method (A) is about \pm 20 percent.

In the case of method (B), which relies on thermal-conductivity averages for geologic units, the accuracy of our in situ estimates is limited mainly by poor sampling. Without representative samples from several boreholes, it is not pos- 
sible to know how thermal conductivity within geologic units varies laterally, and thus we lack a definitive basis for estimating uncertainties. Conversely, if we had a representative data base, uncertainties due to undersampling would not exist. Additional uncertainties introduced by assumptions regarding porosity are not a large concern, but sample bias is. Most of the cores available for thermal-conductivity measurements were cut from potential petroleum-reservoir units and thus are likely to be more biased towards sandy intervals with higher thermal conductivities than would shale-rich units. Consideration of these factors suggests that estimates of in situ thermal conductivities based on averages for geologic units (method (B)) are probably accurate to within about \pm 30 percent. This is approximately the degree to which thermal conductivity varies within homogeneous lithologies collected from diverse sample sites (Roy and others, 1981).

\section{HEAT FLOW}

\section{METHODOLOGY}

For each of the 21 wells in which an equilibrium temperature profile was obtained (fig. 5), a corresponding heatflow estimate was made. For 16 of these 21 wells, we had thermal-conductivity data (mostly from drill chips) from the same well. In these 16 wells heat flow was estimated by the interval method. Equilibrium temperature gradients (fig. 5) were multiplied by in situ thermal conductivities estimated by method (A); interval length was determined by the length of thermal conductivity sample intervals (typically about 10 $\mathrm{m})$. From the interval heat flows a mean heat flow and standard error of the mean were derived. For the 5 wells with equilibrium-temperature logs but no thermal-conductivity data, we calculated heat flow by multiplying the average thermal gradient by an average in situ thermal-conductivity derived using method (B). Heat-flow estimates are summarized in table 3 .

\section{RESULTS}

Heat-flow values and contours are shown in figure 6. Contour lines were calculated by a commercial contouring package (Dynamic Graphics Inc., 1988) and are based on averages derived from an inverse distance weighting procedure smoothed by cubic splines. The contour lines thus represent simple interpolations and extrapolations of the heatflow estimates and have no special physical significance.

Estimated heat flow varies from a low of $27 \pm 6 \mathrm{~mW} / \mathrm{m}^{2}$ at well LBN in the foothills of the Brooks Range (fig. 1) to a high of $90 \pm 19 \mathrm{~mW} / \mathrm{m}^{2}$ at well ATI on the Arctic coast. Heatflow estimates made in earlier USGS studies at Cape Thompson $\left(59 \pm 9 \mathrm{~mW} / \mathrm{m}^{2}\right)$ and Prudhoe Bay $\left(54 \pm 8 \mathrm{~mW} / \mathrm{m}^{2}\right)$ are also shown in figure $6 A$ (Lachenbruch and others, 1966, 1982). Mean heat flow for all 21 wells (Prudhoe Bay and Cape Thompson excepted) is $60 \mathrm{~mW} / \mathrm{m}^{2}$. The mean heat-flow values for Prudhoe Bay, Cape Thompson, and the NPRA are typical of those found in post-Precambrian cratonic settings (Pollack and Chapman, 1977; Vitorello and Pollack, 1980; Pollack and others, 1993).

The heat-flow estimates (fig. 6) show a striking pattern of low heat flow in the foothills of the Brooks Range that increases to the north. Thus, the variation in thermal gradients noted by Lachenbruch and others $(1987,1988)$ cannot be ascribed to simple variations in thermal conductivity in the upper few hundred meters of boreholes. The observed variation in heat flow across the North Slope represents a true, fundamental change in the thermal state of the region. In addition to the heat-flow increase that occurs from south to north over about $300 \mathrm{~km}$, there is a secondary trend with a shorter wavelength of about $50 \mathrm{~km}$ in a direction perpendicular to the main trend. Heat flow in the Ikpikpuk-Umiat basin (fig. 4) is much lower than heat flow over the basement highs (Meade Arch and Fish Creek Platform) to the east and west. Thus both trends in heat flow (north-south and east-west) are inversely correlated with depth to basement.

\section{ERROR ANALYSIS}

In consideration of the low error $\left( \pm 0.1^{\circ} \mathrm{C}\right)$ estimated for equilibrium-temperature logs (fig. 5), the likely error in thermal gradients is negligible in comparison to the likely error in estimated in situ thermal conductivities. For 15 of the heat-flow estimates derived from thermal conductivities calculated by method (A) (drill chips corrected for porosity and anisotropy), we estimate that the heat-flow error

$$
\sigma_{q}=\left[\sigma_{, \lambda}^{2}+\sigma_{s}^{2}\right]^{1 / 2}
$$

where $s_{1}$ is the estimated error introduced by uncertainty in thermal conductivity ( \pm 20 percent) and $\sigma_{s}$ is the standard error of the mean interval heat flow (table 3 ). The above expression is the propagation of variance for uncorrelated random variables (Ross, 1988, p. 276). In most cases, the standard error of the mean $\left(\sigma_{s}\right)$ is significantly less than 20 percent, and typical uncertainties $\left(\sigma_{q}\right)$ are about \pm 21 to \pm 22 percent.

For the 5 heat-flow estimates derived from thermal conductivities estimated by method (B) (formation averages), we estimate that the uncertainty is about \pm 30 percent. This follows from an expectation that the likely error in thermal conductivity is much greater than the likely error in temperature gradients. Heat-flow values and estimated accuracies are summarized in table 3. Error estimates listed in table 3 are conservative estimates of accuracy; in many instances actual errors may be smaller.

In some cases, there are apparent inconsistencies in the interval heat flows. For example, in the case of well JWD 
Table 3. Heat-flow estimates and well locations.

[See figure 1 for well locations. Leaders (- - -), not determined]

\begin{tabular}{|c|c|c|c|c|c|c|c|c|c|}
\hline $\begin{array}{c}\text { Well } \\
\text { designation }\end{array}$ & Well name & $\begin{array}{l}\text { Latitude } \\
\left({ }^{\circ} \mathrm{N}\right)\end{array}$ & $\begin{array}{c}\text { Longitude } \\
\left({ }^{\circ} \mathrm{W}\right)\end{array}$ & $\begin{array}{l}\text { Interval } \\
\text { depth } \\
\text { (m) }\end{array}$ & $\begin{array}{c}\text { Pore } \\
\text { content }\end{array}$ & $\begin{array}{l}\text { Thermal } \\
\text { gradient } \\
\left({ }^{\circ} \mathrm{C} / \mathrm{km}\right)\end{array}$ & $\begin{array}{c}\text { Thermal } \\
\text { conductivity } 1 \\
(\mathrm{~W} / \mathrm{m}-\mathrm{K})\end{array}$ & $\mathrm{N}^{2}$ & $\begin{array}{c}\text { Heat Flow }{ }^{3} \text { and } \\
\text { estimated } \\
\text { accuracy } \\
\left(\mathrm{mW} / \mathrm{m}^{2}\right)\end{array}$ \\
\hline ATI & Atigaru & 70.56 & 151.72 & $\begin{array}{l}155-247 \\
384-622\end{array}$ & $\begin{array}{c}\text { ice } \\
\text { water }\end{array}$ & $\begin{array}{l}24.45 \\
51.13\end{array}$ & $\begin{array}{l}3.30 \\
1.72\end{array}$ & $\begin{array}{l}3 \\
7\end{array}$ & $90 \pm 19$ \\
\hline AWU & Awuna & 69.15 & 158.02 & $739-748$ & water & 22.61 & 1.67 & 1 & $38 \pm 11$ \\
\hline DRP & Drew Point & 70.88 & 153.90 & $\begin{array}{l}116-198 \\
299-628\end{array}$ & $\begin{array}{c}\text { ice } \\
\text { water }\end{array}$ & $\begin{array}{l}31.81 \\
39.02\end{array}$ & $\begin{array}{l}2.48 \\
1.49\end{array}$ & $\begin{array}{r}4 \\
14\end{array}$ & $61 \pm 12$ \\
\hline ES1 & E. Simpson \#1 & 70.92 & 154.62 & $100-581$ & --- & 34.23 & $(1.49)^{4}$ & -- & $51 \pm 15$ \\
\hline ETK & E. Teshekpuk & 70.57 & 152.94 & $274-701$ & water & 42.62 & 1.40 & 16 & $62 \pm 13$ \\
\hline FCK & W. Fish Creek & 70.33 & 152.06 & $\begin{array}{l}100-149 \\
268-693\end{array}$ & $\begin{array}{c}\text { ice } \\
\text { water }\end{array}$ & $\begin{array}{l}43.22 \\
37.09\end{array}$ & $\begin{array}{l}2.58 \\
1.70\end{array}$ & $\begin{array}{r}3 \\
20\end{array}$ & $69 \pm 14$ \\
\hline IKP & Ikpikpuk & 70.46 & 154.33 & $\begin{array}{l}116-143 \\
348-599\end{array}$ & $\begin{array}{c}\text { ice } \\
\text { water }\end{array}$ & $\begin{array}{l}33.82 \\
28.19\end{array}$ & $\begin{array}{l}1.76 \\
1.07\end{array}$ & $\begin{array}{l}2 \\
9\end{array}$ & $38 \pm 10$ \\
\hline JWD & J. W. Dalton & 70.92 & 153.14 & $\begin{array}{l}113-269 \\
406-470\end{array}$ & $\begin{array}{c}\text { ice } \\
\text { water }\end{array}$ & $\begin{array}{l}22.30 \\
47.03\end{array}$ & $\begin{array}{l}2.57 \\
2.54\end{array}$ & $\begin{array}{l}8 \\
3\end{array}$ & $80 \pm 19$ \\
\hline KAG & Kugrua & 70.59 & 158.66 & $\begin{array}{l}107-143 \\
280-536\end{array}$ & $\begin{array}{c}\text { ice } \\
\text { water }\end{array}$ & $\begin{array}{l}41.78 \\
33.01\end{array}$ & $\begin{array}{l}2.02 \\
1.63\end{array}$ & $\begin{array}{r}2 \\
13\end{array}$ & $60 \pm 13$ \\
\hline KOL & Koluktak & 69.75 & 154.61 & $100-226$ & --- & 30.60 & $(1.85)^{4}$ & --- & $57 \pm 17$ \\
\hline KUY & Kuyanak & 70.93 & 156.06 & $100-857$ & --- & 38.94 & $(1.65)^{4}$ & --- & $64 \pm 19$ \\
\hline LBN & Lisburne & 68.48 & 155.69 & $275-522$ & water & 21.27 & 1.38 & 21 & $27 \pm 6$ \\
\hline NIN & N. Inigok & 70.26 & 152.77 & $100-615$ & --- & 37.68 & $(1.77)^{4}$ & --- & $67 \pm 20$ \\
\hline NKP & N. Kalikpik & 70.51 & 152.37 & $264-639$ & water & 46.55 & 1.47 & 15 & $69 \pm 14$ \\
\hline PEA & Peard Bay & 70.72 & 159.00 & $\begin{array}{l}129-138 \\
302-568\end{array}$ & $\begin{array}{c}\text { ice } \\
\text { water }\end{array}$ & $\begin{array}{l}32.28 \\
30.89\end{array}$ & $\begin{array}{l}1.91 \\
1.43\end{array}$ & $\begin{array}{r}1 \\
15\end{array}$ & $47 \pm 10$ \\
\hline SBE & Seabee & 69.38 & 152.18 & $302-384$ & water & 18.15 & 2.62 & 5 & $49 \pm 11$ \\
\hline SME & S. Meade & 70.61 & 156.89 & $188-535$ & water & 44.01 & 1.89 & 24 & $87 \pm 18$ \\
\hline $\mathrm{SOH}$ & S. Harrison Bay & 70.42 & 151.73 & $146-238$ & ice & 32.53 & 2.68 & 8 & $83 \pm 17$ \\
\hline TLK & Tunalik & 70.21 & 161.07 & $276-523$ & water & 37.33 & 0.75 & 12 & $34 \pm 8$ \\
\hline TUL & Tulageak & 71.19 & 155.73 & $100-732$ & --- & 41.95 & $(1.66)^{4}$ & --- & $69 \pm 21$ \\
\hline WDS & W. Dease & 71.16 & 155.63 & $\begin{array}{c}95-169 \\
287-734\end{array}$ & $\begin{array}{c}\text { ice } \\
\text { water }\end{array}$ & $\begin{array}{l}40.70 \\
43.86\end{array}$ & $\begin{array}{l}1.91 \\
1.35\end{array}$ & $\begin{array}{r}4 \\
28\end{array}$ & $61 \pm 12$ \\
\hline
\end{tabular}

${ }^{1}$ Estimated in situ harmonic mean.

${ }^{2}$ Number of thermal conductivity measurements.

${ }^{3}$ Mean interval heat flow.

${ }^{4}$ Calculated from formation averages, table 1.

(fig. 1), the average thermal gradient in the lower, water-saturated region of the borehole $\left(47^{\circ} \mathrm{C} / \mathrm{km}\right)$ is more than twice the thermal gradient in the permafrost $\left(22^{\circ} \mathrm{C} / \mathrm{km}\right)$, yet the estimated in situ thermal conductivity for both intervals is vir- tually the same (table 3 ). At the present time, we have insufficient data to determine if these inconsistencies lie within the scatter of the thermal-conductivity estimates or are indications of unrecognized physical processes. 


\section{SUBSURFACE TEMPERATURE}

Subsurface temperature was estimated from BHT data and ground-surface temperature (Lachenbruch and others, 1987,1988 ) using an average-gradient model and the method of variable bias. This method is described by Deming, Hanor, and Nunn (1990) but simply involves determining average geothermal gradients from weighted least-squares regressions on BHT data. Subsurface-temperature estimates were made along two cross sections (see fig. 1 for location) - north-south cross section $A-A^{\prime}$ (fig. $7 B$ ) and east-west cross section $B-B^{\prime}$ (fig. $8 B$ ).

A large change in thermal gradients and temperature occurs from south to north across the North Slope (fig. 7B). At a depth of $3 \mathrm{~km}$, the maximum temperature difference is $64^{\circ} \mathrm{C}$. This is an order of magnitude larger than the estimated amount of noise $\left( \pm 3^{\circ} \mathrm{C}\right)$ in the BHT data. Although derived from independent data sets, both estimated temperature (fig. $7 B$ ) and heat flow (fig. $7 A$ ) indicate that the North Slope is relatively cold in the south, with much warmer conditions existing in the north. There is also a noticeable tendency for isotherms to be pulled up in the vicinity of basement highs, as would be expected if ground water were being forced up by the structure of the basin. This pulling up of isotherms is particularly apparent in figure $8 B$, which shows that temperature over the Meade Arch and Fish Creek Platform is about $40^{\circ} \mathrm{C}$ higher than temperature at the same depth in the
Ikpikpuk-Umiat basin. Heat flow (fig. 8A) shows a similar pattern. These observations are consistent with the thermal pattern predicted from modeling studies of topographically driven ground-water flow in sedimentary basins (Domenico and Palciauskas, 1973; Smith and Chapman, 1983; Woodbury and Smith, 1985; Deming and Nunn, 1991; Deming, 1993).

\section{INTERPRETATION OF THERMAL DATA}

\section{CONDUCTIVE HYPOTHESES}

Variations in the concentration of radioactive heat-producing elements can lead to significant differences in crustal heat flow, but this is not a likely explanation for the heatflow pattern shown in figure 6. Assuming an average difference in heat production of $2 \mu \mathrm{W} / \mathrm{m}^{3}$ ) between the southern and northern ends of the North Slope, a layer of radioactively enriched crustal rocks $30 \mathrm{~km}$ thick is necessary to explain the observed $60 \mathrm{~mW} / \mathrm{m}^{2}$ variation in heat flow from the foothills of the Brooks Range to the Arctic coastal plain (figure 6A).

High heat flow on the Alaskan north coast cannot be a thermal remnant of Late Jurassic to Early Cretaceous rifting (about $140 \mathrm{Ma}$ ). Over this time span the thermal anomaly related to lithospheric thinning should have decayed to some

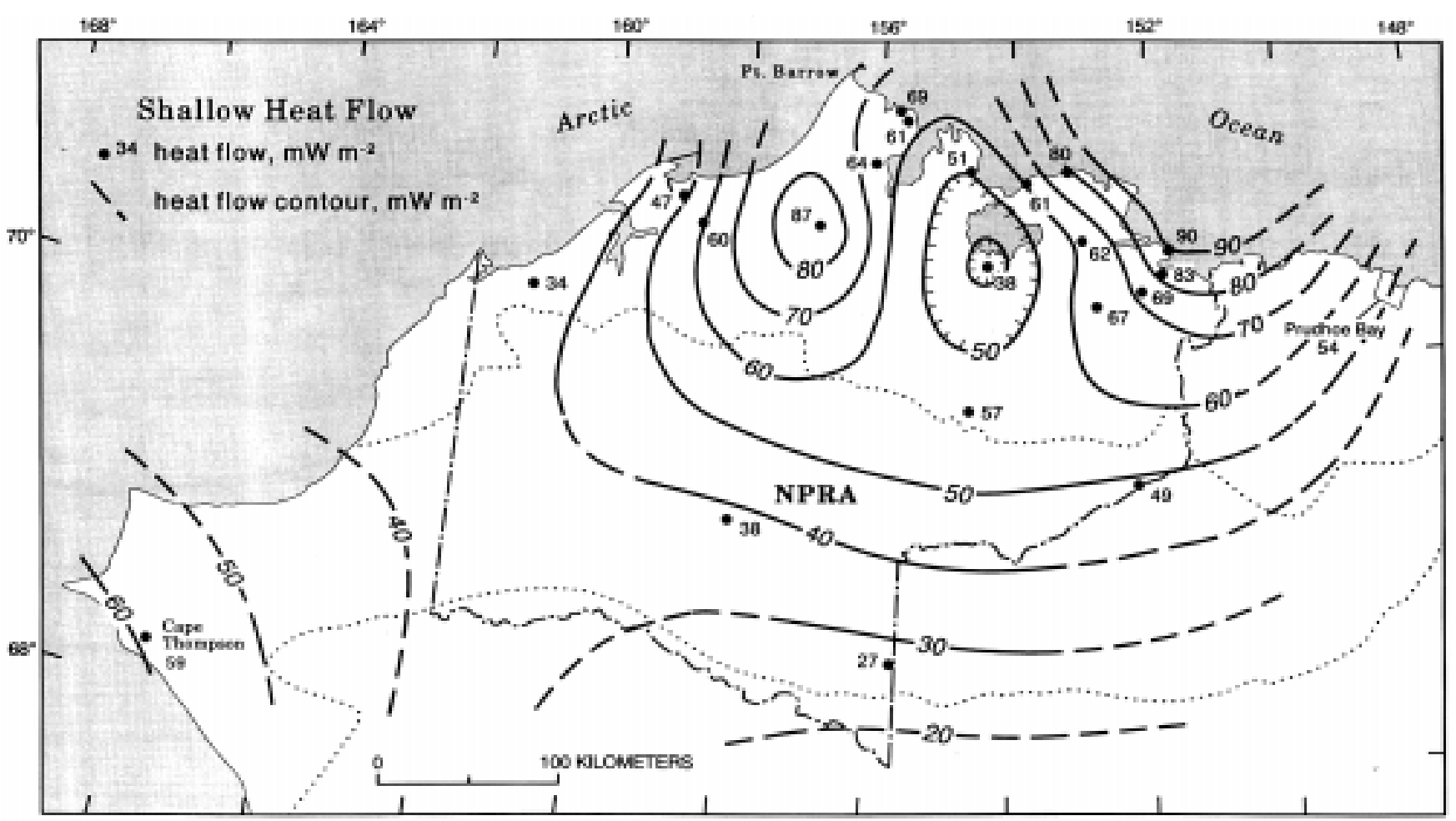

Figure 6. Heat flow $\left(\mathrm{mW} / \mathrm{m}^{2}\right)$ estimated from equilibrium-temperature logs and thermal-conductivity measurements. Estimated error in most cases is about \pm 20 percent. 
small fraction of its initial magnitude (McKenzie, 1978). Similarly, low heat flow over the Colville trough to the south cannot be due to sedimentation, as most sediment was deposited more than 50 m.y. ago (Bird, 1991b). If $h \mathrm{~km}$ of sediment were deposited instantaneously $t$ m.y. ago, the present heatflow anomaly $(\Delta q / q)$ can be determined by

$$
\Delta q / q=-\operatorname{erf}\left\{h /(4 \alpha t)^{1 / 2}\right\}
$$

where erf is the error function, $h$ is $7 \mathrm{~km}$, the thermal diffusivity $(\alpha)$ is $32 \mathrm{~km}^{2} / \mathrm{m} . \mathrm{y}$., and $t$ is $50 \mathrm{~m}$.y., yielding a heat-flow anomaly of $\sim 0.10$. Because the present-day heat flow increases by as much as 300 percent from the foothills of the Brooks
Range to the Arctic coastal plain, sedimentation alone cannot explain the observed pattern.

The higher temperatures inferred over basement arches are not related to the refraction of heat into more conductive rocks of the basement (for example, fig. $8 B$ ) because the angles involved are much too small (note vertical exaggeration of fig. $8 \mathrm{~B}$ ) for appreciable heat refraction (Lachenbruch and Marshall, 1966) and because thermal conductivity measurements (table 2) show that the argillite that composes the bulk of the upper part of the basement is no more conductive than overlying Ellesmerian sequence rocks.

The overall trend in the North Slope of low heat flow in the south and higher heat flow in the north (fig. 6) could be

A

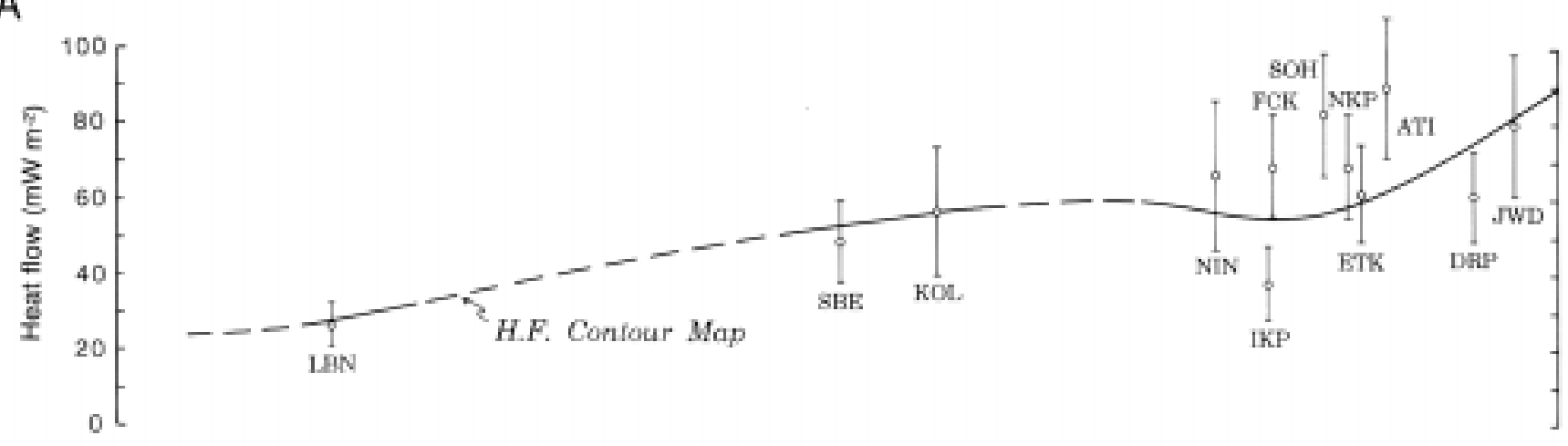

B

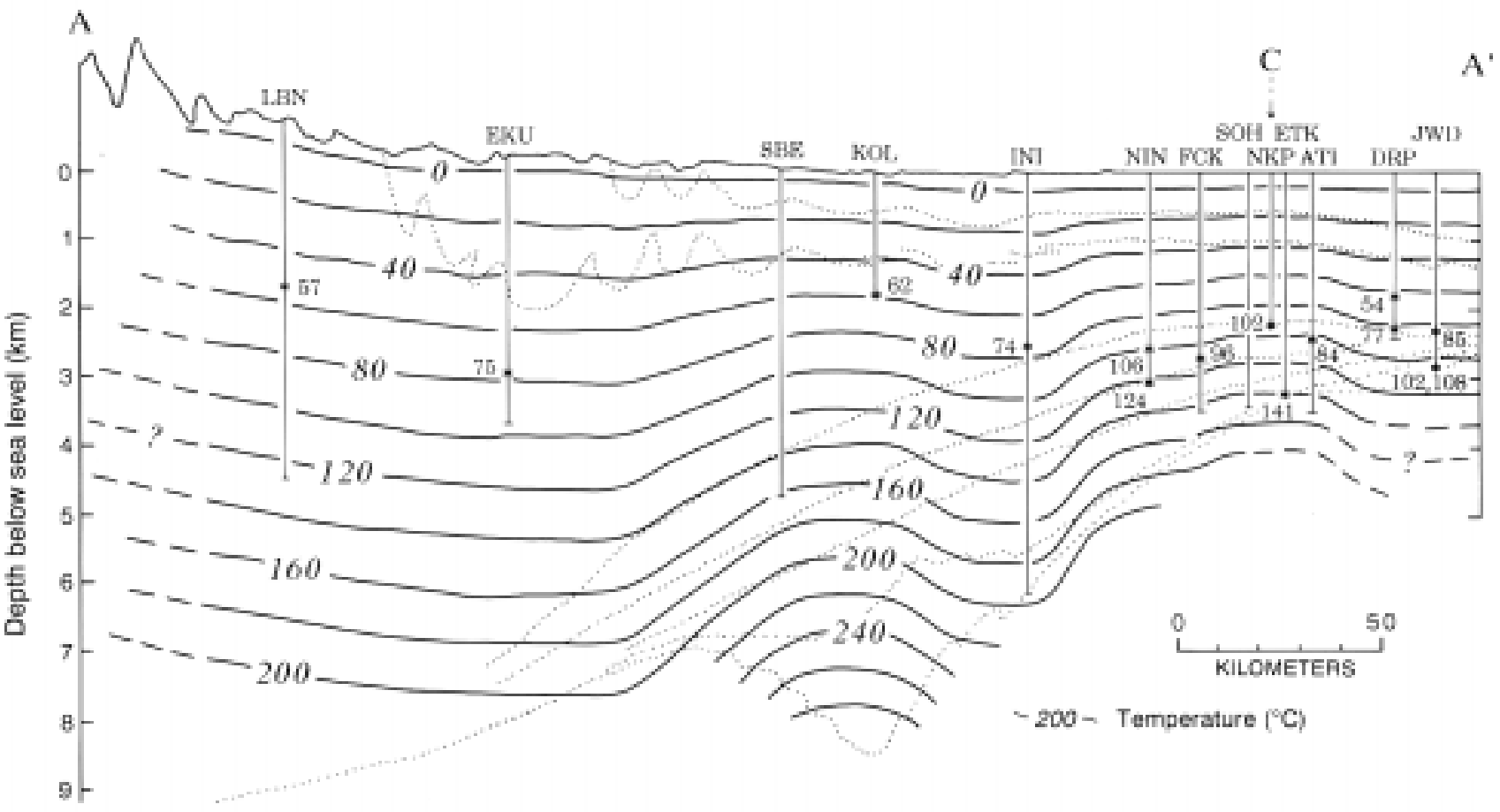

Figure 7. Estimates of heat flow $\left(\mathrm{mW} / \mathrm{m}^{2}\right)(A)$ and subsurface temperature in degrees Celsius $(B)$ along north-south cross section A-A' (figs. 1 and 3). $B$ also shows borehole locations and corrected bottom-hole temperatures (BHT's) projected onto cross section. 
due to a deep-seated change in heat flow at the base of the crust, resulting from some unknown mechanism. However, the rapid east-west variation in heat flow (figs. 6, 8A) is probably incompatible with such a source.

Hypotheses involving thermal perturbations related to the migration of lakes on the coastal plain have been considered and dismissed by Lachenbruch and others $(1987,1988)$. Several of the wells such as JWD and ATI are located onshore within a few hundred meters of the sea coast (fig. 1), but the shoreline transgression is so rapid in these areas (Hopkins and Hartz, 1978) that effects on our borehole temperature profiles are negligible, owing to the relatively slow speed with which heat diffuses through rock by conduction (Lachenbruch, 1957; Lachenbruch and others, 1987, 1988). Some of the coastal sites might have been inundated during higher sea level stands associated with interglacial periods, and it is conceivable that subsequent regressions of the sea cooled the emerging land surface and thus temporarily increased the near-surface heat flow. However, the last transgression probably occurred 30,000 to 100,000 years ago (Carter and others, 1986), and the magnitude of any perturbations to the near-surface heat flow is small compared to the magnitude of the observed spatial variations in heat flow. For example, assuming an instantaneous regression with $10^{\circ} \mathrm{C}$
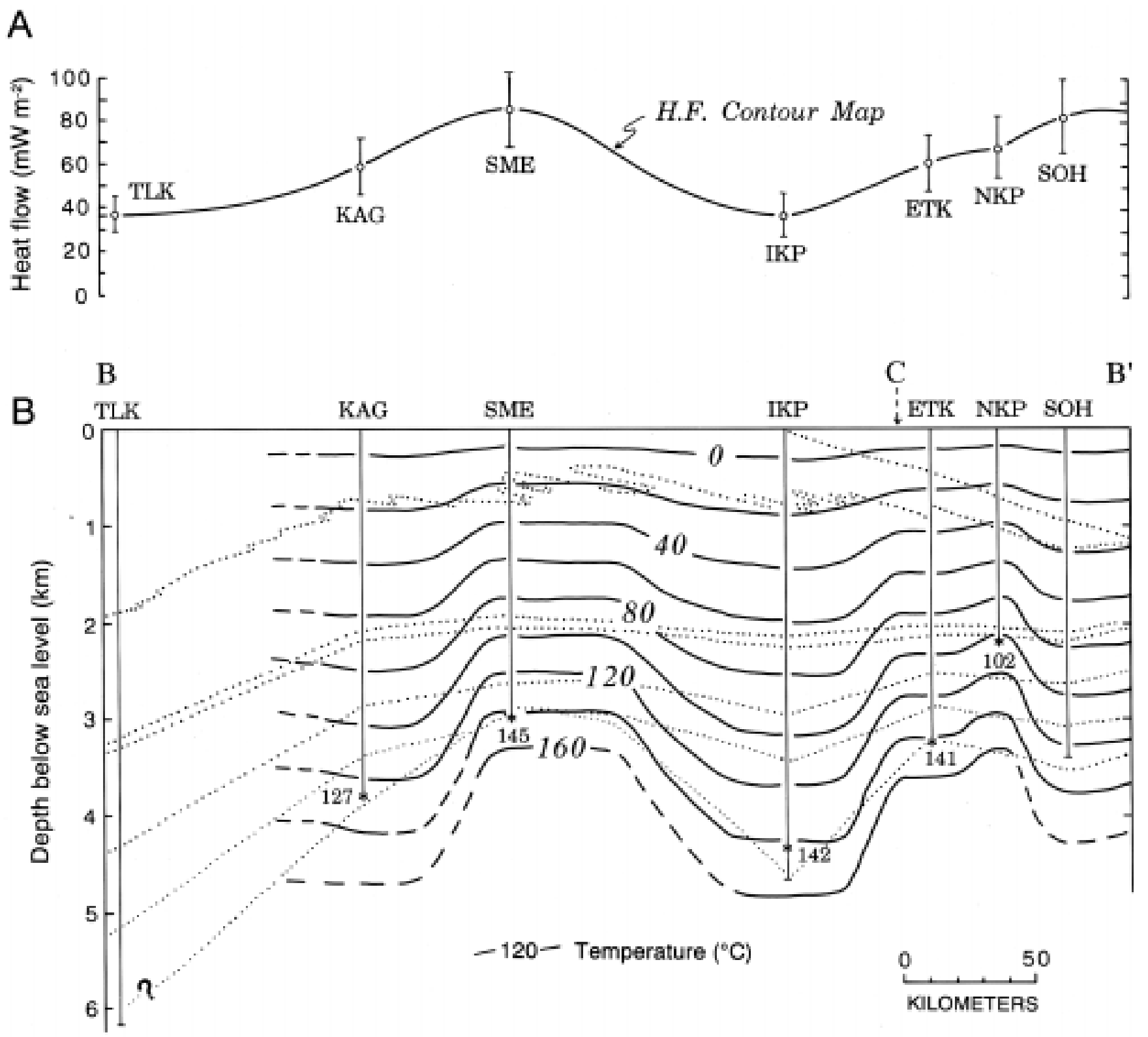

Figure 8. Estimates of heat flow $\left(\mathrm{mW} / \mathrm{m}^{2}\right)(A)$ and subsurface temperature in degrees Celsius $(B)$ along east-west cross section B-B' (figs. 1 and 4 ). $B$ also shows borehole locations and corrected bottom-hole temperatures (BHT's) projected onto cross section. 
cooling of the ground surface 30,000 years before the present, the maximum possible perturbation to the thermal gradient in the top $1,000 \mathrm{~m}$ of our boreholes is about $6^{\circ} \mathrm{C} / \mathrm{km}$. The likely perturbation is probably much smaller, considering that the ground surface has been alternately cooled and warmed by at least two transgressions and regressions of the sea over the last 130,000 years (Carter and others, 1986).

\section{GROUND-WATER FLOW}

Average heat flow on the North Slope $\left(60 \mathrm{~mW} / \mathrm{m}^{2}\right)$ is approximately equal to the apparent background heat flow (50 to $60 \mathrm{~mW} / \mathrm{m}^{2}$ ), as determined on the periphery of the region at areas such as Prudhoe Bay and Cape Thompson (Lachenbruch and others, 1966, 1982). When this coincidence is considered in conjunction with the distribution of low heat flow in areas of high elevation and high heat flow in areas of low elevation, it is strongly suggestive of forced convection by gravity-driven ground-water flow (see, for example, modeling studies such as that by Smith and Chapman, 1983).

Any hydrologic interpretation, however, must take into account the presence of relatively thick (average $300 \mathrm{~m}$ ), largely continuous permafrost on the North Slope, which would tend to obstruct both inflow and outflow of a hypothetical circulation system. Thawed areas that bridge the permafrost (taliks) or open fractures must be postulated to ac- commodate an active flow system. In all physiographic provinces, taliks may exist underneath large bodies of water, including large, deep lakes and major rivers. Numerous lakes with depths in the range of 6 to $21 \mathrm{~m}$ are found on the coastal plain, including Lake Teshekpuk (fig. 1), which covers an area of $815 \mathrm{~km}^{2}$ (Sloan, 1987). Borehole and probe data, along with seismic studies, indicate that offshore the north coast of Alaska the distribution of ice-bonded permafrost underneath the sea is patchy and irregular (Sellman and Hopkins, 1984). Thus, ground-water discharge may occur underneath large, deep lakes on the coastal plain or underneath the sea. The bulk of the ground water recharge probably takes place in the Brooks Range, where rugged topography and locally thick snow cover in winter months provide insulation from cold air temperatures, retarding and limiting subsurface freezing. The same snow cover provides abundant meltwater in spring and summer months, with recharge facilitated by permeable, coarse-grained glacial outwash sediments in mountain valleys or by fractured and cavernous carbonate rocks (Hopkins and others, 1955; Williams and Everdingen, 1973; Sloan, 1987). The presence of more than 50 springs throughout the Brooks Range apparently constitutes conclusive evidence of ground-water infiltration and active subterranean groundwater flow. Most of these springs are found in the Brooks Range and its foothills to the east of the NPRA and typically issue from (1) fault zones where the limestone of the Lisburne Group comes into contact with other rocks or (2) solution-

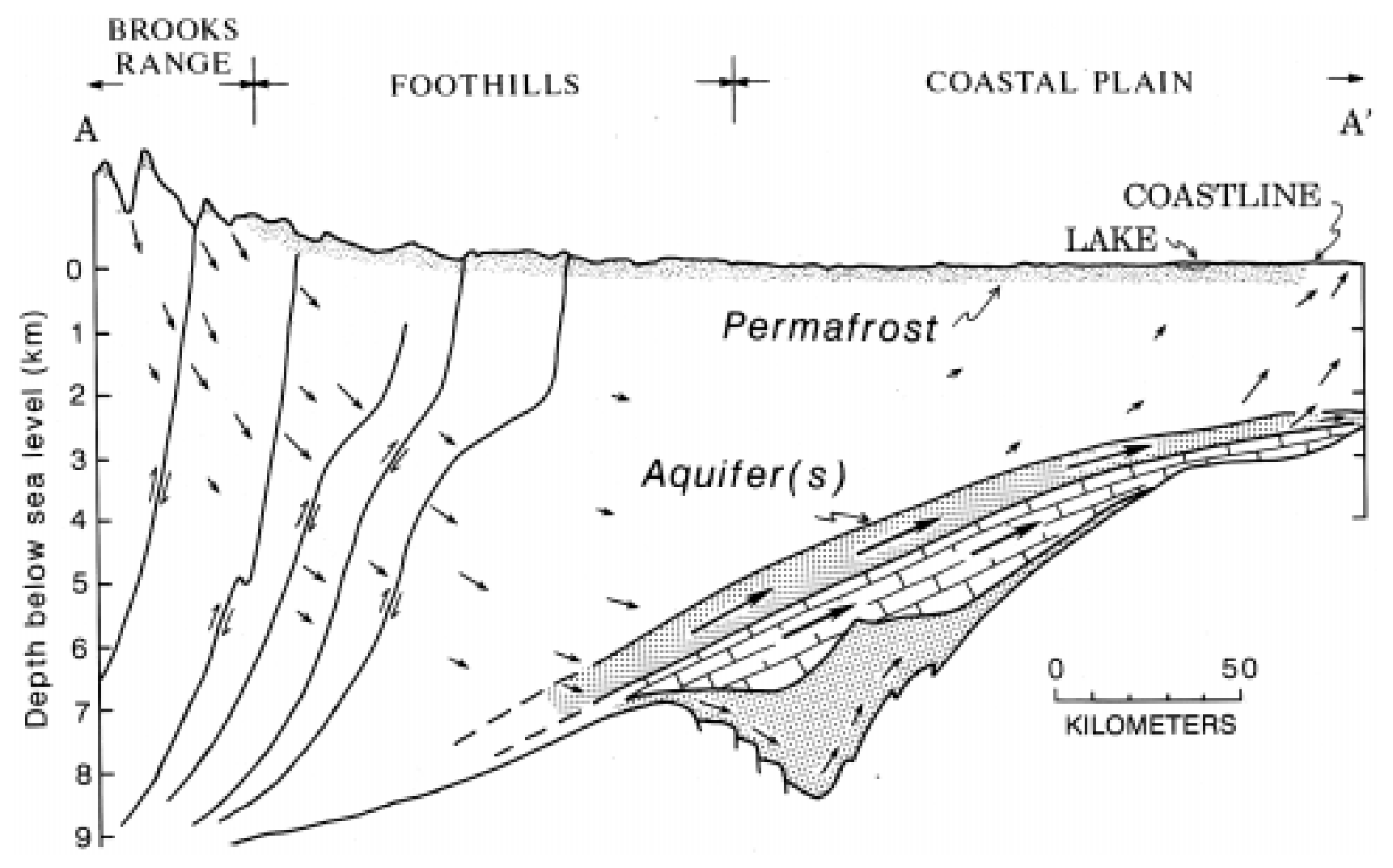

Figure 9. Conceptual model of regional ground-water flow for the North Slope of Alaska. 
enlarged fractures in the Lisburne Group (Williams and Everdingen, 1973; Sloan, 1987). Fractured carbonates apparently are important aquifers for ground-water recharge, transmission, and discharge (Sloan, 1987, p. 246).

A conceptual model (fig. 9) illustrates how moving ground water could redistribute heat throughout the North Slope. Cold water enters at high elevations in the Brooks Range and is diverted to the north laterally through a structurally disturbed region in the direction of decreasing hydraulic head. As water percolates downward through the south half of the basin, its temperature increases as it absorbs heat that would otherwise warm the sediments, thereby decreasing the thermal gradient. Ground water preferentially follows the path of least resistance (highest permeability), and the locus of ground-water migration probably is one or more potential aquifers in Ellesmerian sequence rocks, which subsequently channel and focus flow through the north half of the North Slope. Potential aquifers include the Sadlerochit Group (sandstone), Lisburne Group (limestone and dolomite), and Endicott Group (sandstone). The upward flow of heated water along these aquifers leads to elevated temperatures and heat flow across the north half of the North Slope. Eventual discharge occurs underneath large, deep lakes on the coastal plain or, more likely, underneath the sea.

Additional insight into hypothetical ground-water flow paths can be obtained from inspection of superimposed heatflow and structure-contour maps of the basement rocks (fig. $10 A$ ), as well as maps of the Lisburne (fig. 10B) and the Sadlerochit Groups (fig. 10C). Shallow heat-flow contours generally mimic basement contours (fig. 10A); lower heat flow correlates with increased depth to basement. However, heat flow is not controlled by basin structure alone, as might be expected for ground-water flow through a basin of homogeneous permeability. Wells TUL, WDS, and KUY on the Barrow Arch (fig. 6) occupy the structurally most elevated part of the North Slope but have modest heat flows in the range of 61 to $69 \mathrm{~mW} / \mathrm{m}^{2}$. Wells along the coast to the east (notably JWD and ATI, fig. 6) have higher heat flows ( 80 and $90 \mathrm{~mW} /$ $\mathrm{m}^{2}$ ), although depth to basement is twice as great as in the Barrow area. This is consistent with the idea of ground-water flow being concentrated in Lisburne Group limestone, because this group is absent in the Barrow area (fig. 10B). Lisburne Group limestone is also the source of springs in the Brooks Range to the east of the NPRA (Williams and Everdingen, 1973; Sloan, 1987). Ground-water flow through the Lisburne Group alone, however, is insufficient to explain the high heat flow at well SME $\left(87 \mathrm{~mW} / \mathrm{m}^{2}\right.$, fig. 6$)$ because the Lisburne is absent at well SME. There must also be a

Figure 10. Heat flow $\left(\mathrm{mW} / \mathrm{m}^{2}\right)$ (heavy solid lines, dashed where inferred) and structure-contour maps (light dashed lines) showing depth in feet $(1 \mathrm{ft}=0.3048 \mathrm{~m})$ to top of basement rocks $(A)$, Lisburne Group $(B)$, and Sadlerochit Group $(C)$. Structure contours are after Bird (1988).
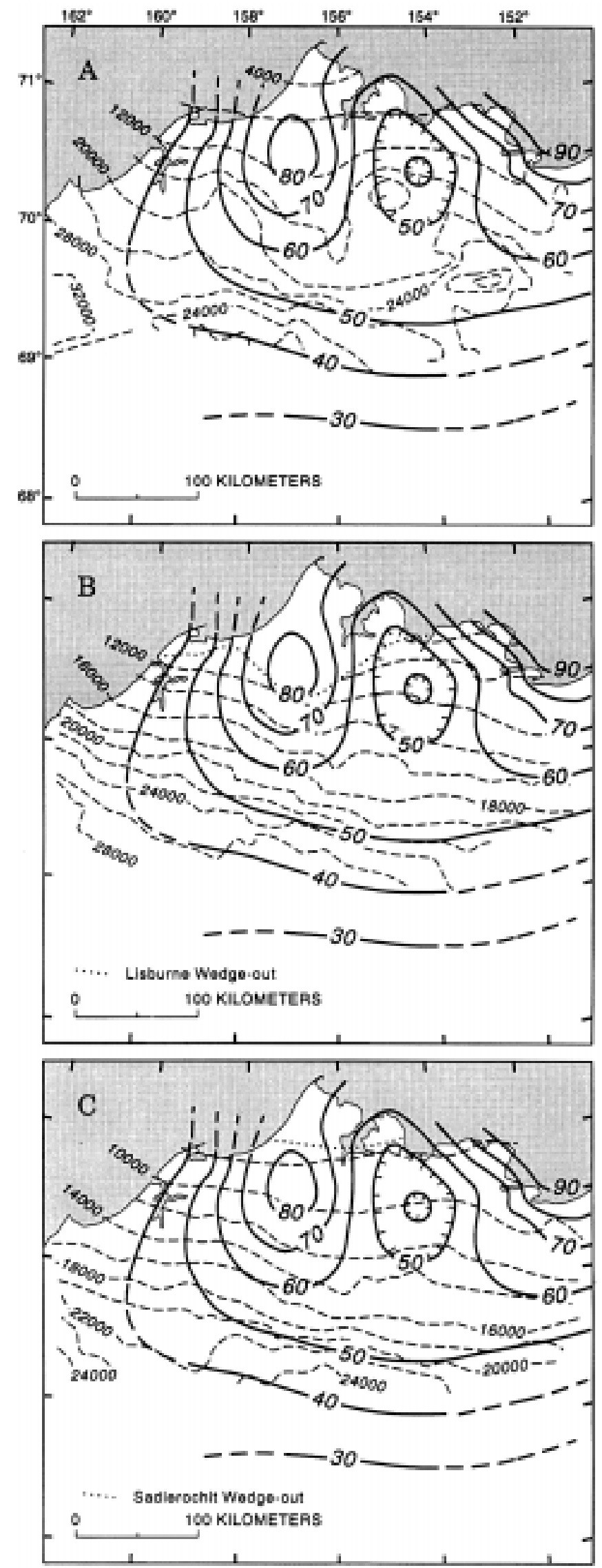
significant component of flow through Sadlerochit Group sandstone (fig. 10C). This unit is present at well SME but is (like the Lisburne Group) absent at the Barrow area wells (TUL, WDS, KUY, fig. 10).

Incidental evidence that supports the hypothesis of basin-scale ground-water flow on the North Slope has been reported by Kharaka and Carothers (1988), Woodward (1987), and Sloan (1987). Kharaka and Carothers (1988) found that formation water from seven wells on the coastal plain was relatively low in dissolved solids $(19,000$ to $24,000 \mathrm{mg} / \mathrm{L})$ and concluded from an analysis of oxygen isotope ratios that it was meteoric in origin. Similarly, Woodward (1987) concluded from analysis of spontaneous potential logs that connate water in the sandstone of the Ivishak Formation of the Sadlerochit Group had been displaced by meteoric water. Sloan (1987, p. 243) reports artesian flow in wells drilled through the permafrost in the foothills of the Brooks Range.

\section{MATHEMATICAL MODELS}

We developed some simple mathematical models to quantify out ground-water flow hypothesis. These models allowed us to estimate the average permeability of the rocks on the North Slope and average ground-water velocity in the hypothetical flow system. The models also enabled us to test whether the proposed ground-water flow system could explain the observed heat flow data in the presence of the continuous and impermeable ice-rich layer of permafrost that is present throughout the foothills and coastal plain provinces of the North Slope.

\section{CHANNEL MODEL}

Perhaps the simplest model is a V-shaped channel (fig. 11 ), where flow is confined by permafrost on the top and relatively impermeable basement rocks on the bottom. Over the left half of the model (descending channel) the heat flow that is lost to the downward flow of ground water is

$$
\Delta q l_{1}=v \rho C\left(T_{2}-T_{1}\right) b
$$

where $\Delta q$ is the average heat flow deficit over the horizontal length of the descending channel $\left(l_{1}\right), v$ is the Darcy velocity or specific discharge, $\rho$ is fluid density, $C$ is fluid specific heat, $T_{1}$ and $T_{2}$ are fluid temperatures at ends of the pipe, and $b$ is height of the channel. If we take the hingeline of the flow system to be near the north-south midpoint of the basin where the surface heat flow is approximately equal to the apparent background heat flow (see fig. $7 A$ ), then $l_{1}=170,000 \mathrm{~m}$. If we further take $\Delta q=0.02 \mathrm{~W} / \mathrm{m}^{2}, \rho=1,000 \mathrm{~kg} / \mathrm{m}^{3}, C=4,200(\mathrm{~J} / \mathrm{kgK})$, $T_{1}=0^{\circ} \mathrm{C}, T_{2}=180^{\circ} \mathrm{C}$ (see fig. $7 B$ ), and $b=2,000 \mathrm{~m}$, then $v=0.07$ $\mathrm{m} / \mathrm{yr}$.

The effective basin-scale permeability can be estimated by applying Darcy's law. Let $s$ be a distance coordinate along the channel model (fig. 11). The average head gradient ( $\partial h /$ $\partial s$ ) in the channel can then be approximated by the total drop in head $(\Delta h=1,500 \mathrm{~m})$ across the basin divided by the width of the basin $(\Delta s=340,000 \mathrm{~m})$. By Darcy's law the permeability $k$ is then given by

$$
k=(v \Delta s \mu / \rho g \Delta h)
$$

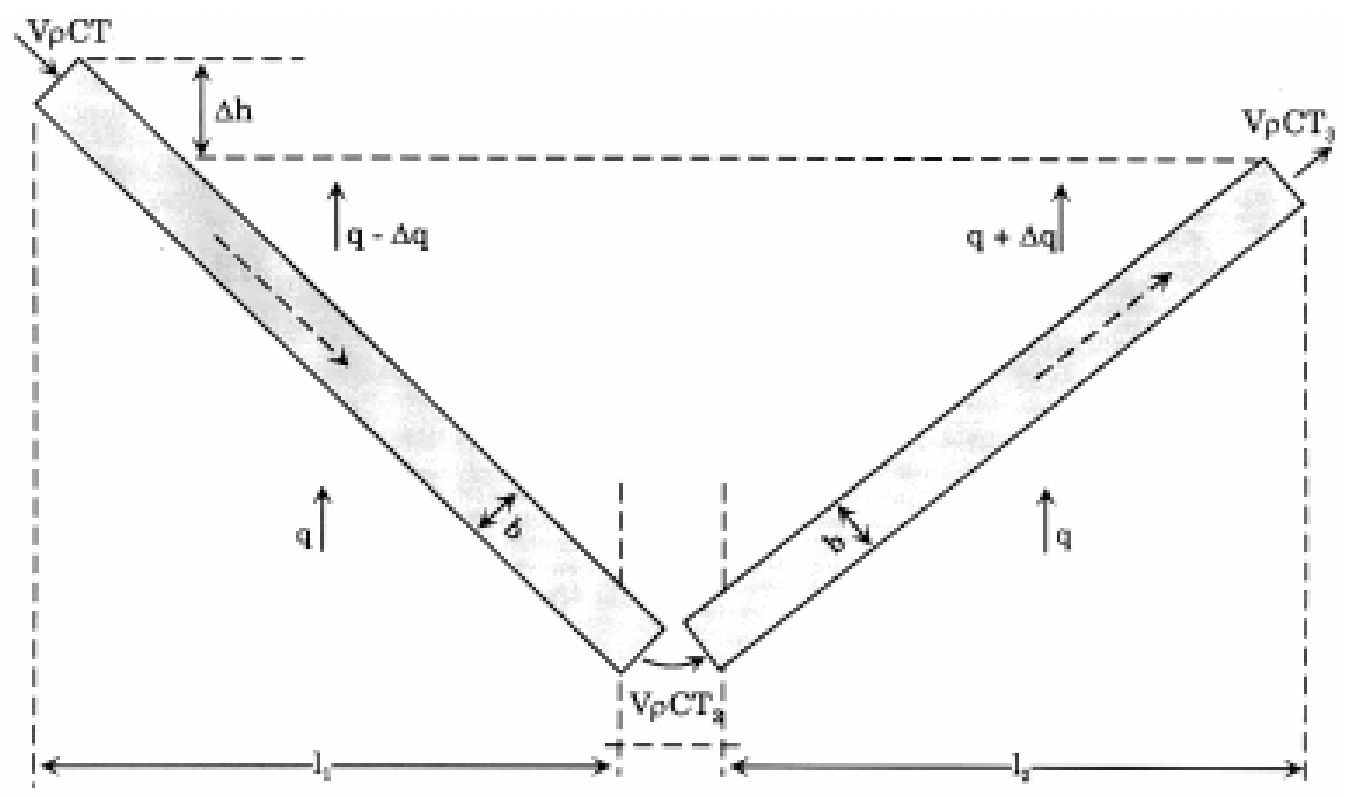

Figure 11. V-shaped channel model of hypothetical ground-water flow system showing energy balance. 
where $v$ is the Darcy velocity of water moving through the channel, $\mu$ is dynamic viscosity, $\rho$ is fluid density, and $g$ is the acceleration due to gravity. If we take $v=0.07 \mathrm{~m} / \mathrm{yr}$, $\mu=5 \times 10^{-4} \mathrm{~kg} / \mathrm{m} \cdot \mathrm{s}$ (water at $50^{\circ} \mathrm{C}$ ) $, \rho=1,000 \mathrm{~kg} / \mathrm{m}^{3}$, and $g=9.8$ $\mathrm{m} / \mathrm{s}^{2}$, then $k=3 \times 10^{-14} \mathrm{~m}^{2}$.

These estimates of the average Darcy velocity and basin-scale permeability are dependent on an assumption regarding the thickness $(b)$ of the flow system model. For example, if we take the thickness of the channel model $(b)$ to be $100 \mathrm{~m}$ (instead of $2000 \mathrm{~m}$ ), our estimates of both the Darcy velocity and permeability increase by a factor of 20 . By themselves, the thermal data are insufficient to enable us to discern the degree to which ground-water flow through the basin may be concentrated in high-permeability aquifers.

\section{NUMERICAL MODEL}

A somewhat more complex hydrogeologic model of the North Slope was developed by discretizing a north-south geologic cross section (fig. 3) into nine different areas in which permeability and thermal conductivity were specified as constants (fig. 12). Areas 1 through 7 were based on stratigraphic divisions; the equivalent geologic units are listed in table 4. Area 8 was equivalent to the structurally disturbed region south of the foothills province that extends into the Brooks Range. The northern edge of area 8 demarcates the limit of information obtained from seismic data regarding the bound- aries and locations of geologic units. Lacking detailed knowledge of the complex geologic structure in the Brooks Range and its foothills, we could do no better than treat it as homogeneous. Area 9 represented basement rocks. These nine areas were further subdivided into 5,459 finite difference nodes, and a numerical method was used to obtain quasi steady-state solutions of equations describing heat and mass transport. Fluid flow in the model occurred in response to both head and density gradients and was affected by temperature to the extent that temperature influences fluid density and viscosity. The presence of permafrost throughout the foothills province and the Arctic coastal plain was simulated by an impermeable boundary condition over areas of the model corresponding to these physiographic provinces (stippled area, fig. 12). Although temperatures in the Brooks Range are sufficiently cold to maintain permafrost, ground water evidently infiltrates through taliks that exist as a consequence of the rugged topography. Offshore of the Arctic coastal plain, the distribution of permafrost is likely to be patchy and irregular, as discussed earlier. More detailed descriptions of the numerical model, including the governing equations, solution technique, and boundary conditions are given by Deming (1993) and Deming and Nunn (1991).

Permeability data used in the model were collected from 2,498 published core measurements. Information on the methodology and assumptions used in these measurements and interpretations is of variable extent, quality, and availability. Measurements on cores collected during the 1944 to 1953

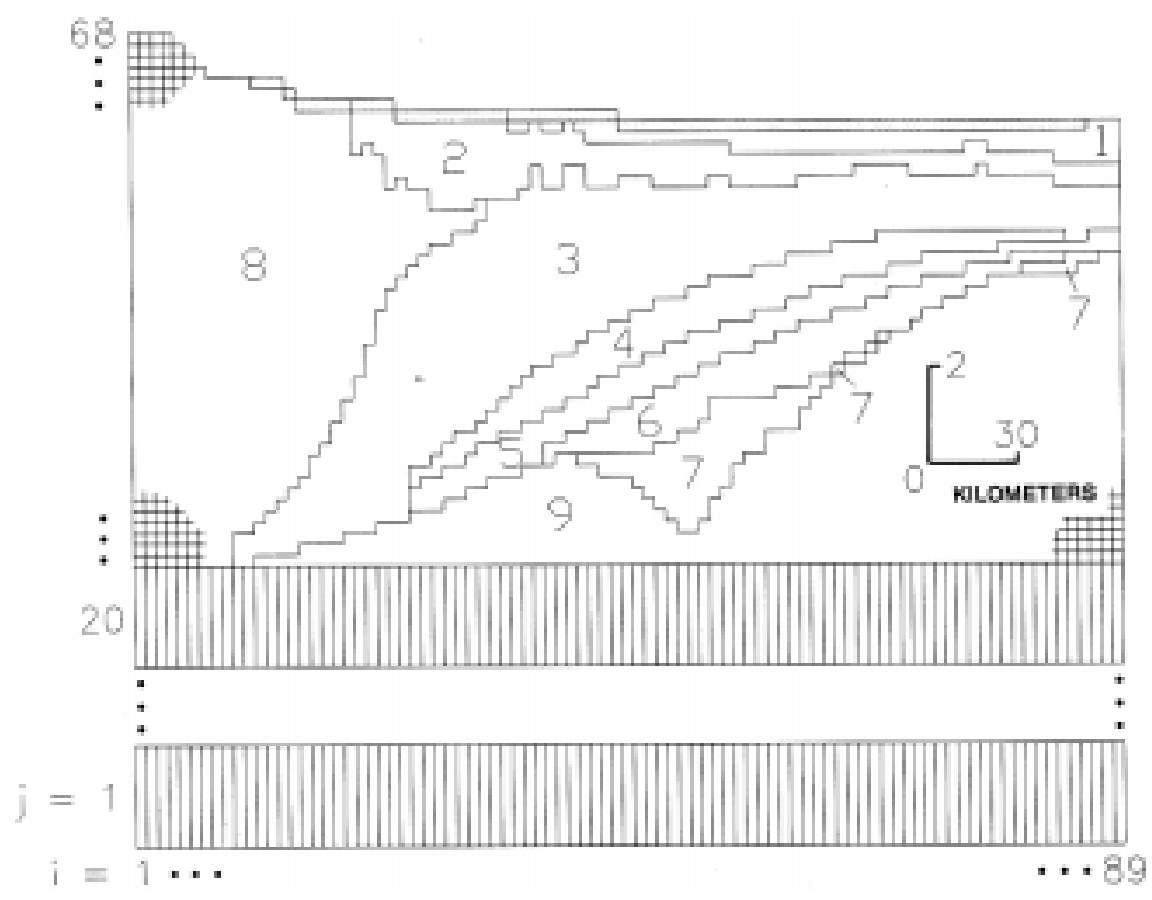

Figure 12. Numerical model of heat transfer and ground water flow on the North Slope of Alaska. Note vertical exaggeration (about 17:1) and division into nine geologic units with homogeneous thermal and hydrologic properties. 
Table 4. Permeabilities and thermal conductivities used in numerical model (fig. 12).

\begin{tabular}{|c|c|c|c|c|c|}
\hline \multirow{2}{*}{$\begin{array}{l}\text { Model } \\
\text { unit }\end{array}$} & \multirow{2}{*}{$\begin{array}{c}\text { Geologic } \\
\text { unit }\end{array}$} & \multirow{2}{*}{$\begin{array}{c}\text { Thermal } \\
\text { conductivity } \\
(\mathrm{W} / \mathrm{m}-\mathrm{K})\end{array}$} & \multicolumn{3}{|c|}{ Permeability $\left(10^{-15} \mathrm{~m}^{2}\right)$} \\
\hline & & & Horizontal & & Vertical \\
\hline 1 & Colville $\mathrm{Gp}$. & 2.2 & 78 & & .25 \\
\hline 2 & Nanushuk Gp. & 1.4 & 100 & & .21 \\
\hline 3 & Torok Fm. & 1.7 & .9 & 7 & .12 \\
\hline 4 & $\begin{array}{l}\text { Pebble shale unit, } \\
\text { Kuparuk Fm., and } \\
\text { Kingak Sh. }\end{array}$ & 2.0 & 45 & & .26 \\
\hline 5 & $\begin{array}{l}\text { Sag River Ss. } \\
\text { Shublik Fm. } \\
\text { Sadlerochit Gp. }\end{array}$ & 2.5 & 29 & & .19 \\
\hline 6 & Lisburne Gp. & 3.0 & 1.6 & & .12 \\
\hline 7 & Endicott Gp. & 3.2 & 220 & & .59 \\
\hline 8 & 2 & .5 & 61 & & .21 \\
\hline 9 & Basement rocks & 2.5 & 0 & & 0 \\
\hline
\end{tabular}

NPRA exploration program are reported in USGS professional paper 305 (U.S. Geological Survey, 1956). Measurements on cores collected during the 1974 to 1982 exploration program are listed in individual geologic summary reports prepared by Husky Oil corporation for the USGS. Horizontal permeabilities used in the model were taken as arithmetic averages of measurements made parallel to bedding; vertical permeabilities used in the model were derived from harmonic averages of measurements perpendicular to bedding. An examination of permeability data collected from North Slope formations reveals that many permeability measurements made on cores perpendicular to bedding were reported as zero, evidently reflecting that the lower limit of measurement sensitivity was $10^{-16} \mathrm{~m}^{2}$. In these instances we used a value of 10 ${ }^{16} \mathrm{~m}^{2}$ to derive average permeability values to be used in the model. Thus, the average vertical permeabilities used in the model may be somewhat high, but permeability in the basin itself could be considerably higher than core measurements would indicate, owing to the possible presence of fractures (for example, see Bredehoeft and others' (1983) study of the Pierre Shale in South Dakota). Permeability and thermal-conductivity values used in the numerical model are summarized in table 4.

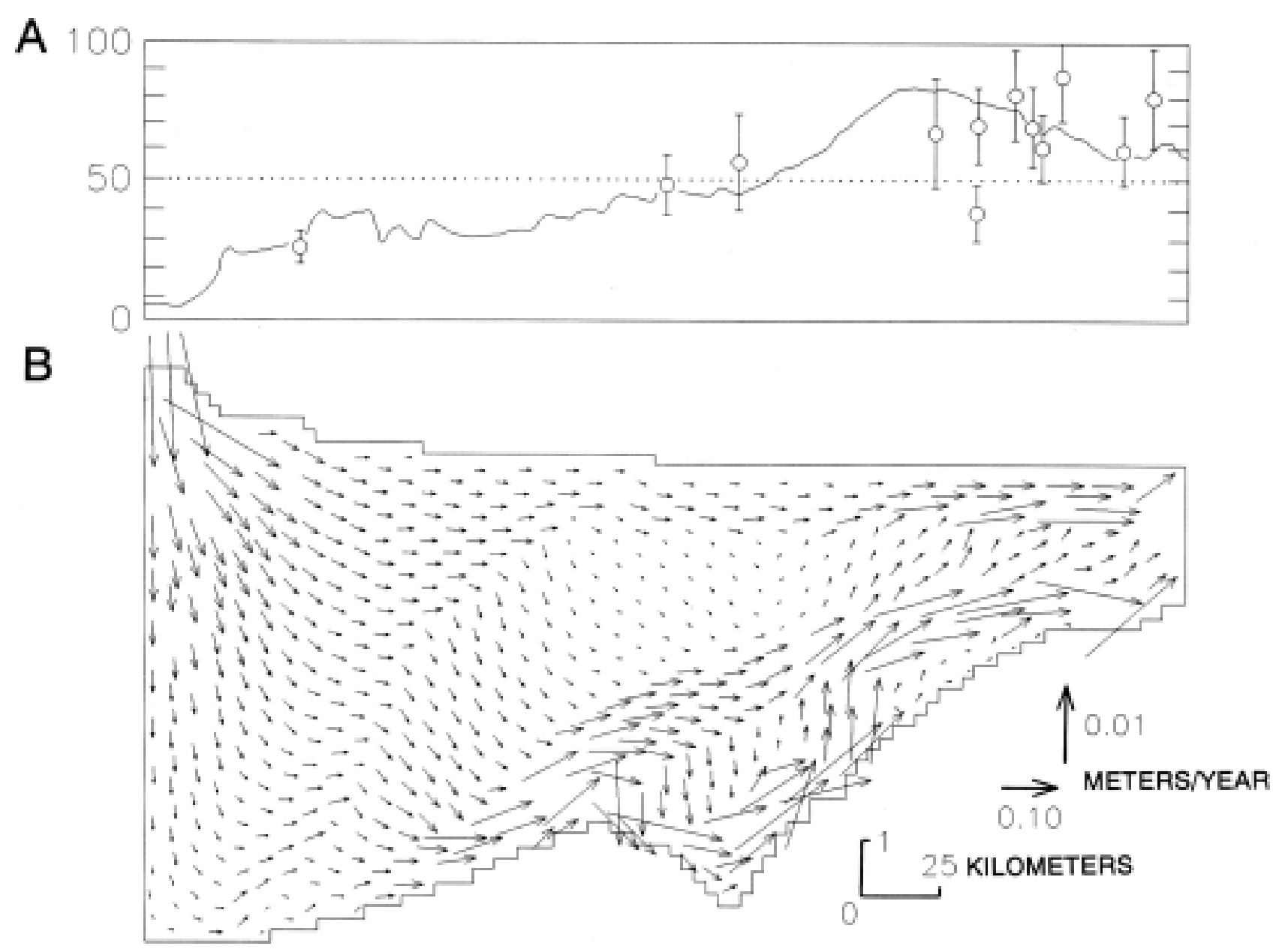

Figure 13. Near-surface heat flow $\left(\mathrm{mW} / \mathrm{m}^{2}\right)(A)$ and Darcy velocity $(\mathrm{m} / \mathrm{yr})(B)$ for a numerical model simulation of heat and fluid transport through the North Slope. In $A$ heat flow predicted by model simulation is shown as a solid line and heat-flow estimates made in field studies are shown as discrete points with error bars. Background heat flow (dotted line) is $50 \mathrm{~mW} / \mathrm{m}^{2}$. 
Near-surface heat flow predicted by the numerical model matches the general trend of heat flow estimated from borehole studies (fig. 13). Heat flow in the foothills of the Brooks Range is severely depressed, while heat flow in the coastal plain is considerably elevated above the background level. In consideration of the idealized nature of the numerical model and the scatter introduced into the heat-flow data by the artificial process of projecting them onto a two-dimensional cross section, the match between the model prediction and observed data is probably about as good as may be expected. Deming (1993) conducted a similar series of model simulations in which the permeability of the entire model was specified as homogeneous and anisotropic. The results of these simulations were that acceptable matches to the heat-flow data could be obtained if the specified model permeability parallel to bedding $\left(k_{x}\right)$ was in the range $2.5 \times 10^{-}$ ${ }^{14} \leq k_{x} \leq 2.5 \times 10^{-13} \mathrm{~m}^{2}$, and permeability perpendicular to bedding $\left(k_{z}\right)$ was in the range $1.0 \times 10^{-16} \leq k_{z} \leq 5.0 \times 10^{-16} \mathrm{~m}^{2}$. The range of acceptable permeabilities inferred from these model simulations encompassed the available permeability data, as the arithmetic average of all 2,031 permeability measurements on cores made parallel to bedding was $6.1 \times 10^{-14} \mathrm{~m}^{2}$.

Model simulations showed that the presence of an impermeable top boundary in sections of the model that corresponded to the presence of permafrost was evidently not an impediment to the existence of a basinwide underground flow system. In fact, Deming (1993) showed that better matches to the heat-flow data could be obtained when the permafrost layer is in place than when it is absent.

\section{DISCUSSION}

There is no question that ground-water flow through the North Slope exists; it is the magnitude and velocity of subsurface flow that is difficult to discern. If the water table in the Brooks Range and Arctic coastal plain is near the ground surface, a hydraulic-head gradient exists between these two points, owing to differences in elevation. According to Darcy's law, the velocity of volumetric flow through a porous medium is directly proportional to the permeability and head gradient (Deming, 1994c). Thus, because the average head gradient is fixed by elevation, the rate at which underground flow occurs is essentially determined by the permeability of rocks in the basin. The results of both of our mathematical models indicate that the permeability required for the existence of a subsurface flow system of sufficient magnitude to significantly perturb the thermal regime on the North Slope is consistent with the results of permeability measurements on core samples.

Contrary to the intuition of many geologists, it is possible for ground-water flow to have significant effects on the thermal regime of a sedimentary basin even if rocks in a basin are relatively impermeable and ground-water velocities relatively low. Lachenbruch and Sass (1977) showed that the degree to which ground-water flow depresses (or increases) the geothermal gradient and conductive heat flow has an exponential dependence upon the depth of circulation. Under steady-state conditions

$$
q_{\mathrm{top}} / q_{\mathrm{bot}}=\mathrm{e}^{\Delta z / s}
$$

where $q_{\text {top }}$ is the conductive heat flow at the top of a layer of thickness $\Delta z, q_{\text {bot }}$ is the conductive heat flow at the bottom of the layer, and

$$
s=\lambda / \rho C v
$$

where $\lambda$ is the thermal conductivity of a porous medium, $\rho$ and $C$ are the density and heat capacity of a fluid moving with Darcy velocity $v$, and $v$ is negative for downward flow. Thus, the magnitude of a thermal anomaly that is due to subsurface fluid circulation increases exponentially as the depth of circulation increases linearly. Assuming typical values of $\lambda=2.5 \mathrm{~W} / \mathrm{m} \cdot \mathrm{K}, \rho=1,000 \mathrm{~kg} / \mathrm{m}^{3}$, and $C=4,200 \mathrm{~J} / \mathrm{kgK}$, the nearsurface conductive heat-flow (and geothermal gradient) is reduced to 59 percent of the basal value for downward percolation through $1,000 \mathrm{~m}$ of a porous medium at a Darcy velocity of $1 \mathrm{~cm} / \mathrm{yr}$. However, if the extent of fluid movement reaches a depth of $5 \mathrm{~km}$, then conductive heat flow at the surface is reduced to 7 percent of the basal value for the same Darcy velocity of $1 \mathrm{~cm} / \mathrm{yr}$. As a consequence of the exponential dependence on depth, the background thermal regime in the Earth's crust can be appreciably perturbed by fluid moving at relatively low velocities $\left(10^{-3}\right.$ to $\left.10^{-2} \mathrm{~m} / \mathrm{yr}\right)$. Significant disturbances are possible even in sedimentary basins, such as the Colville basin on the North Slope, which have thick sequences of relatively impermeable shaly rocks; the presence of factors such as high-permeability aquifers, extensive fracture networks, and conspicuous signs of underground water flow (for example, artesian wells) is not a prerequisite.

Our simple conceptual and mathematical models are appropriate for deriving first-order estimates of ground-water velocities and regional-scale permeabilities. However, we believe there are three-dimensional aspects to the postulated ground-water flow system. The extended lobe of low heat flow centered around well IKP (fig. 6) suggests that flow is channeled preferentially through this part of the North Slope. Significant basement depressions are found in the vicinity of well IKP and about $100 \mathrm{~km}$ to the southeast of IKP (see fig. $10 A)$. Isopach maps (Bird, 1988) show thick sections of Endicott Group sandstone and Lisburne Group limestone filling these depressions. These potential aquifers are likely to constitute a preferred high-permeability channel for fluid flow, and flow may converge laterally into this channel from the east and west, while maintaining the general direction of south to north ground-water migration. Ground-water flow then apparently diverges in a "T" before reaching the Alaskan north coast, passing over the Meade Arch to the west and Fish Creek platform to the east. This is indicated by both the shallow and 
deep heat-flow maps (fig. 6) and estimated temperature (fig. $8 B)$.

Although we interpret the lobe of low heat flow centered around well IKP (fig. 6A) to be a consequence of threedimensional focusing related to subsurface structure, the estimated value $\left(38 \pm 10 \mathrm{~mW} / \mathrm{m}^{2}\right)$ at well IKP appears to be anomalously low when compared to estimates made at wells to the south. For example, heat flow at well KOL is $57 \pm 17$ $\mathrm{mW} / \mathrm{m}^{2}$, although well KOL is $80 \mathrm{~km}$ to the south of well IKP and well IKP is structurally higher in relation to the basement (fig. $10 A)$ by about $4,000 \mathrm{ft}(1,219 \mathrm{~m})$. It may be that flow diverges in the vicinity of well KOL but converges near well IKP, or perhaps, the apparent discrepancy can simply be attributed to overlapping error bars. We do not consider it likely that our shallow heat-flow estimate at well IKP is spurious because the deep temperature there is also relatively low (fig. 8B).

Studies of organic maturation (Magoon and Bird, 1987, 1988) indicated paleothermal states were qualitatively consistent with present-day temperatures on the North Slope. The vertical separation between vitrinite reflectance $\left(R_{o}\right)$ values of 0.6 and 2.0 percent increases from about $1.5 \mathrm{~km}$ in the north of the basin, to $4.5 \mathrm{~km}$ in the south of the basin (Bird, 1991a, b). Because erosion has dominated over sedimentation for the last 75 m.y. in the NPRA section of the North Slope (Bird, 1987), it is likely that the present state of organic maturation was "frozen in" at the time of maximum burial, tens of millions of years ago. Thus, the type of dramatic variation in thermal state we see today on the North Slope was apparently also present at the time of maximum burial, which was probably about 75 m.y. ago (Bird, 1993). If this variation is due to a ground-water flow system driven by topography on the Brooks Range, then it is conceivable that the ground-water flow system has persisted since uplift began about 100 m.y. ago. In accordance with the hydraulic theory of petroleum migration (Hubbert, 1953; Toth, 1988), this same ground-water flow system may be the mechanism by which petroleum was flushed out of the basin and accumulated at Prudhoe Bay, the structural high point for Ellesmerian sequence rocks and the terminus of the ancient petroleum migration system 65 m.y. ago (Bird, 1987).

\section{CONCLUSIONS}

1. Both heat flow and subsurface temperature on the North Slope vary systematically from relatively low values in the foothills of the Brooks Range to much higher values on the coastal plain to the north.

2. Variations in the thermal state of the North Slope can be explained by the existence of a topographically driven ground-water-flow system that transports heat by advection from areas of high elevation in the Brooks Range and its foothills to areas of low elevation on the Arctic coastal plain; all of the alternative explanations known to us are unsatisfactory.

3. Idealized mathematical models of basin-scale groundwater flow through the North Slope over distances of more than $300 \mathrm{~km}$ show that basin-scale ground-water flow can result in perturbations to the background thermal state that are consistent with the spatial variation observed in heat-flow data. Regional ground-water flow may occur even if the entire Brooks Range foothills and Arctic coastal plains provinces are overlain by a relatively thick $(\sim 300 \mathrm{~m})$, continuous layer of ice-rich, impermeable permafrost. The hypothetical ground-water flow system can be maintained by recharge in the Brooks Range, with discharge occurring offshore, where the distribution of ice-rich permafrost may be patchy and irregular.

4. The average Darcy velocity of ground-water flow through the North Slope is estimated to be of the order of 0.1 $\mathrm{m} / \mathrm{yr}$; the effective basin-scale permeability is estimated to be of the order of $10^{-14} \mathrm{~m}^{2}$.

5. Organic-maturation data collected in other studies indicate that systematic variations in the thermal state of the North Slope may have persisted for tens of millions of years. The ground-water flow system that is likely responsible for these variations may have persisted for the same period of time, possibly providing the mechanism by which petroleum migrated to Prudhoe Bay.

\section{ACKNOWLEDGMENTS}

This research was supported in part by a National Research Council Postdoctoral Fellowship held by David Deming. Acknowledgment is made to the Donors of The Petroleum Research Fund, administered by the American Chemical Society, for partial support of this research. We thank Ken Bird for providing geologic cross sections; any mistakes should be attributed to subsequent modification by the authors. We are grateful to George Gryc and Max Brewer, who greatly facilitated our field operations at NPRA. Husky Oil NPR Operations Inc. completed the wells in a manner that allowed detailed temperature profiles and provided core and cuttings samples. John P. Kennelly Jr., Thomas H. Moses Jr., and Walter E. Wendt of the U. S. Geological Survey designed and built the rugged equipment that was necessary to acquire the field data and helped to deploy it. We thank David C. Blanchard and Irvin L. Tailleur of the U.S. Geological Survey for stimulating discussions regarding bottom-hole temperatures. Additional help in the field was provided by Peter Galanis, Frederick V. Grubb, Lawrence A. Lawver, B. Vaughn Marshall, and Jackson R. Porter of the U.S. Geological Survey. Thermal conductivities were measured by Robert J. Munroe and Eugene P. Smith of the U. S. Geological Survey. The authors thank Ken Bird and Steve Ingebritsen of the U.S. Geological Survey for reviews which helped to improve the manuscript. 


\section{REFERENCES CITED}

Bird, K.J., 1987, The framework geology of the north slope of Alaska as related to oil-source correlations, in Tailleur, I., and Weimer, P., eds., Alaskan North Slope geology, v. 1: Bakersfield, California, Pacific section, Society of Economic Paleontologists and Mineralogists, p. 121-141.

1988, Structure-contour and isopach maps of the National Petroleum Reserve in Alaska, in Gryc, G., ed., Geology and exploration of the National Petroleum Reserve in Alaska, 1974 to 1982: U.S. Geological Survey Professional Paper 1399, p. 355-377.

_ 1991a, Geology, play descriptions, and petroleum resources of the Alaskan North Slope (petroleum provinces 58-60): U.S. Geological Survey Open-File Report 88-450Y, 52 p.

1991b, North slope of Alaska, in Gluskoter, H.J., Rice, D.D., and Taylor, R.B., eds., Economic geology, United States, oil and gas section, part III. Regional synthesis of selected provinces, Chapter 29: Boulder, Colorado, Geological Society of America, The geology of North America, v. P-2, p. 447-462.

1992, The North Slope Foreland Basin, Alaska, in Macqueen, R.W., and Leckie, D.A., eds., Foreland basins and foldbelts: American Association of Petroleum Geologists Memoir 55, p. 363-393.

1994, The Ellesmerian(!) petroleum system, North Slope of Alaska, USA, in Magoon, L.B., and Dow, W.G., eds., The petroleum system-From source to trap: American Association of Petroleum Geologists, p. 339-358.

Blackwell, D.D., and Steele, J.L., 1989, Thermal conductivity of rocks-measurement and significance, in Naeser, N.D., and McCulloh, T.H., eds., Thermal history of sedimentary basins: methods and case histories: Springer-Verlag, New York, p. 13 36.

Blanchard, D.C., and Tailleur, I.L., 1982, Temperatures and interval geothermal gradients determinations from wells in National Petroleum Reserve in Alaska: U.S. Geological Survey OpenFile Report 82-391, 79 p.

Bredehoeft, J.D., Neuzil, C.E., and Milly, P.C.D., 1983, Regional flow in the Dakota Aquifer: a study of the role of confining layers: U.S. Geological Survey Water Supply Paper 2237.

Bullard, E.C., 1947, The time necessary for a borehole to attain temperature equilibrium: Monthly Notes of the Royal Astronomical Society, v. 5, p. 127-130.

Carter, L.D., Brigham-Brette, J., and Hopkins, D.M., 1986, Late Cenozoic marine transgressions of the Alaskan Arctic Coastal Plain, in Heginbottom, J. A., and Vincent, J. S., eds., Correlation of Quaternary deposits and events around the Beaufort Sea: Geological Survey of Canada Open File Report 1237, p. 2126.

Chapman, D.S., Keho, T.H., Bauer, M.S., and Picard, M.D., 1984, Heat flow in the Uinta basin determined from bottom hole temperature (BHT) data: Geophysics, v. 49, p. 453-466.

Deming, D., 1989, Application of bottom-hole temperature corrections in geothermal studies: Geothermics, v. 18, p. 775-786.

1993, Regional permeability estimates from investigations of coupled heat and groundwater flow, North Slope of Alaska: Journal of Geophysical Research, v. 98, p. 16271-16286.

- 1994a, Overburden Rock, Temperature and Heat FlowEssential Elements of the Petroleum System, in Magoon, L. B., and Dow, W. G., eds., The Petroleum System-From Source to Trap: American Association of Petroleum Geologists Mem- oir 60 , p. $165-186$.

1994b, Estimation of the thermal conductivity anisotropy of rock with application to the determination of terrestrial heat flow: Journal of Geophysical Research, v. 99, p. 22087-22091.

1994c, Fluid Flow and Heat Transport in the Upper Continental Crust: in Parnell, J., ed., Geofluids: Origin, Migration and Evolution of Fluids in Sedimentary Basins, Geological Society Special Publication No. 78, p. 27-42

Deming, D., and Chapman, D.S., 1988, Heat flow in the Utah-Wyoming thrust belt from analysis of bottom-hole temperature data measured in oil and gas wells: Journal of Geophysical Research, v. 93, p. 13657-13672.

Deming, D., Hanor, J.S., and Nunn, J.A., 1990, Method of variable bias and its application to estimating subsurface temperature: Geophysical Research Letters, v. 17, p. 1949-1952.

Deming, D., and Nunn, J.A., 1991, Numerical simulations of brine migration by topographically driven recharge: Journal of Geophysical Research, v. 96, p. 2485-2499.

Deming, D., Nunn, J.A., Jones, S., and Chapman, D.S., 1990, Some problems in thermal history studies, in Nuccio, V.F., and Barker, C.E., eds., Applications of thermal maturity studies to energy exploration: Boulder, Colorado, Rocky Mountain Section, Society of Economic Paleontologists and Mineralogists, p. 6180.

Domenico, P.A., and Palciauskas, V.V., 1973, Theoretical analysis of forced convective heat transfer in regional ground-water flow: Geological Society of America Bulletin, v. 84, p. 38033814.

Dynamic Graphics Inc., 1988, Interactive Surface Modeling, Berkeley, California,

Garven, G., and R.A. Freeze, 1984, Theoretical analysis of the role of groundwater flow in the genesis of stratabound ore deposits, 2. Quantitative results: American Journal of Science, v. 284, p. $1125-1174$.

Grubbe, K., Haenel, R., and Zoth, G., 1983, Determination of the vertical component of thermal conductivity by line source methods: Zentrablatt fur Geologie und Palaontologie Teil I, p. 4956.

Gryc, G., ed., 1988, Geology and exploration of the National Petroleum Reserve in Alaska, 1974 to 1982: U.S. Geological Survey Professional Paper 1399, 940 p.

Hopkins, D.M., and Hartz, R.W., 1978, Coastal morphology, coastal erosion, and barrier islands of the Beaufort sea, Alaska: U.S. Geological Survey Open-File Report 78-1063, 50 p.

Hopkins, D.M., Karlstrom, T.N.V., Black, R.F., Williams, J.R., Pewe, T.L., Fernold, A.T., and Muller, E. H., 1955, Permafrost and ground water in Alaska: U. S. Geological Survey Professional Paper 264-F, p. 113-144.

Hubbert, M.K., 1953, Entrapment of petroleum under hydrodynamic conditions: Bulletin of the American Association of Petroleum Geologists, v. 37, p. 1954-2026.

Kappelmeyer, O., and Haenel, R., 1974, Geothermics with special reference to application: Berlin, Gebruder Borntraeger, $238 \mathrm{p}$.

Kharaka, Y.K., and Carothers, W.W., 1988, Geochemistry of oilfield water from the north slope, in Gryc, G., ed., Geology and exploration of the National Petroleum Reserve in Alaska, 1974 to 1982: U.S. Geological Survey Professional Paper 1399, p. 551-561.

Lachenbruch, A.H., 1957, Thermal effects of the ocean on permafrost: Geological Society of America Bulletin, v. 68, p. 15151529 . 
Lachenbruch, A.H., and Brewer, M.C., 1959, Dissipation of the temperature effect of drilling a well in Arctic Alaska: U.S. Geological Survey Bulletin 1083C, p. 73-109.

Lachenbruch, A.H., Greene, G.W., and Marshall, B.V., 1966, Permafrost and the geothermal regimes, in Wilimovsky, N. J., and Wolfe, J. N., eds., Environment of the Cape Thompson region, Alaska: U.S. Atomic Energy Commission, Division of Technical Information, Washington, D.C., p. 149-163.

Lachenbruch, A.H., and Marshall, B.V., 1966, Heat flow through the Arctic Ocean floor: the Canada Basin-Alpha rise boundary: Journal of Geophysical Research, v. 71, p. 1223-1248.

1986, Changing climate; geothermal evidence from permafrost in the Alaskan Arctic: Science, v. 234, p. 689-696.

Lachenbruch, A.H., and Sass, J.H., 1977, Heat flow in the United States and the thermal regime of the crust, in Heacock, J.G., ed., The Earth's crust, its nature and physical properties: American Geophysical Union Monograph 20, p. 626-675.

Lachenbruch, A.H., Sass, J.H., Lawver, L.A., Brewer, M.C., Marshall, B.V., Munroe, R.J., Kennelly, J.P., Jr., Galanis, S.P., Jr., and Moses, T.H., Jr., 1987, Temperature and depth of permafrost on the Alaskan Arctic slope, in Tailleur, I., and Weimer, P., eds., Alaskan North Slope geology, v. 2: Bakersfield, California, Pacific section, Society of Economic Paleontologists and Mineralogists, p. 545-558.

1988, Temperature and depth of permafrost on the Alaskan Arctic slope, in Gryc, G., ed., Geology and exploration of the National Petroleum Reserve in Alaska, 1974 to 1982: U.S. Geological Survey Professional Paper 1399, p. 645-656.

Lachenbruch, A.H., Sass, J.H., Marshall, B.V., and Moses, T.H., Jr., 1982, Permafrost, heat flow, and the geothermal regime at Prudhoe Bay, Alaska: Journal of Geophysical Research, v. 87, p. 9301-9316.

Luheshi, M.N., 1983, Estimation of formation temperatures from borehole measurements: Geophysical Journal of the Royal Astronomical Society, v. 74, p. 747-776.

McKenzie, D., 1978, Some remarks on the development of sedimentary basins: Earth and Planetary Science Letters, v. 40, p. $25-32$.

Magoon, L.B., and Bird, K.J., 1987, Alaskan North Slope petroleum geochemistry for the Shublik Formation, Kingak Shale, pebble shale unit, and Torok Formation, in Tailleur, I., and Weimer, P., eds., Alaskan North Slope Geology, v. 1: Bakersfield, California, Pacific section, Society of Economic Paleontologists and Mineralogists, p. 145-160.

1988, Evaluation of petroleum source rocks in the National Petroleum Reserve in Alaska, using organic-carbon content, hydrocarbon content, visual kerogen, and vitrinite reflectance, in Gryc, G., ed., Geology and exploration of the National Petroleum Reserve in Alaska, 1974 to 1982: U.S. Geological Survey Professional Paper 1399, p. 381-450.

Molenaar, C.M., Bird, K.J., and Collett, T.S., 1986, Regional correlation sections across the North Slope of Alaska: U.S. Geological Survey Miscellaneous Field Studies Map MF-1907.

Pollack, H.N., and Chapman, D.S., 1977, On the regional variation of heat flow, geotherms, and the thickness of the lithosphere: Tectonophysics, v. 38, p. 279-296.

Pollack, H.N., Hurter, S.J., and Johnson, J.R., 1993, Heat flow from the earth's interior: analysis of the global data set: Reviews of Geophysics, v. 31, p. 267-280.

Ross, S., 1988, A first course in probability: New York, Macmillan, $420 \mathrm{p}$.
Roy, R.F., Jr., Beck, A.E., and Touloukian, Y.S., 1981, Thermophysical properties of rocks, in Touloukian, Y. S., Judd, W. R., and Roy, R. F., eds., Physical properties of rocks and minerals, McGraw-Hill CINDAS Data Series on Material Properties, v. II-2: New York, McGraw Hill, p. 409-502.

Sass, J.H., Lachenbruch, A.H., Moses, T.H., Jr., and Morgan, P., 1992, Heat flow from a scientific research well at Cajon Pass, California: Journal of Geophysical Research, v. 97, p. 50175030.

Sass, J.H., Lachenbruch, A.H., and Munroe, R.J., 1971, Thermal conductivity of rocks from measurements on fragments and its application to heat-flow determinations: Journal of Geophysical Research, v. 76, p. 3391-3401.

Sass, J.H., Kennelly, J.P., Jr., Smith, E.P., and Wendt, W.E., 1984, Laboratory line-source methods for the measurement of thermal conductivity of rocks near room temperature: U.S. Geological Survey Open-file Report 84-91, 21 p.

Sass, J.H., Stone, C., and Munroe, R.J., 1984, Thermal conductivity determinations on solid rock-A comparison between a steadystate divided bar apparatus and a commercial transient linesource device: Journal of Volcanology and Geothermal Research, v. 20, p. 145-153.

Sellman, P.V., and Hopkins, D.M., 1984, Subsea permafrost distribution on the Alaskan shelf, in Fourth International Conference on Permafrost, final proceedings: National Academy Press, Washington, D.C., p. 75-82.

Shen, P.Y., and Beck, A.E., 1986, Stabilization of bottom hole temperature with finite circulation time and fluid flow: Geophysical Journal of the Royal Astronomical Society, v. 86, p. 63-90.

Sloan, C.E., 1987, Water resources of the North Slope, Alaska, in Tailleur, I., and Weimer, P., eds., Alaskan North Slope geology, v. 1: Bakersfield, California, Pacific section, Society of Economic Paleontologists and Mineralogists, p. 233-252.

Smith, L., and Chapman, D.S., 1983, On the thermal effects of groundwater flow 1. Regional scale systems: Journal of Geophysical Research, v. 88, p. 593-608.

Tailleur, I., and Weimer, P., eds., 1987, Alaskan North Slope geology: Bakersfield, California, Pacific section, Society of Economic Paleontologists and Mineralogists, book 50, 874 p.

Tissot, B.P., Pelet, R., and Ungerer, P., 1987, Thermal history of sedimentary basins, maturation indices, and kinetics of oil and gas generation: American Association of Petroleum Geologists Bulletin, v. 71, p. 1445-1466.

Toth, J., 1988, Ground water and hydrocarbon migration, in Back, W., Rosenhein, J. S., and Seaber, P. R., eds., The Geology of North America, v. O-2, Hydrogeology: Boulder, Colorado, Geological Society of America, p. 485-502.

Touloukian, Y.S., Liley, D.E., and Saxena, S.L., 1970, Thermophysical properties of matter, v. 3; Thermal conductivity: nonmetallic liquids and gases: New York, Plenum, p. 120.

U.S. Geological Survey, 1956, Exploration of Naval Petroleum Reserve No. 4 and adjacent areas, northern Alaska, 1944-53, U.S. Geological Survey Professional Paper 305 A-F.

Vitorello, I., and Pollack, H.N., 1980, On the variation of continental heat flow with age and the thermal evolution of continents: Journal of Geophysical Research, v. 85, p. 983-995.

Williams, J.R., and van Everdingen, R.O., 1973, Groundwater investigations in permafrost regions of North America: A review, in Proceedings of the second international conference on permafrost, Yakutsk, July 1973, North American contribution, National Academy of Sciences, National Research Council, Washington, D.C., p. 435-446. 
Woodbury, A.D., and Smith, L., 1985, On the thermal effects of three-dimensional groundwater flow: Journal of Geophysical Research, v. 90, p. 759-767.
Woodward, P.V., 1987, Regional evaluation of formation fluid salinity by SP log, Ivishak Sandstone, North Slope, Alaska (abstract): American Association of Petroleum Geologists Bulletin, v. 71, p. 629. 


\title{
Late Mesozoic and Cenozoic Thermotectonic evolution of the Colville Basin, North Slope, Alaska
}

\author{
By Paul B. O'Sullivan ${ }^{1}$
}

\section{CONTENTS}

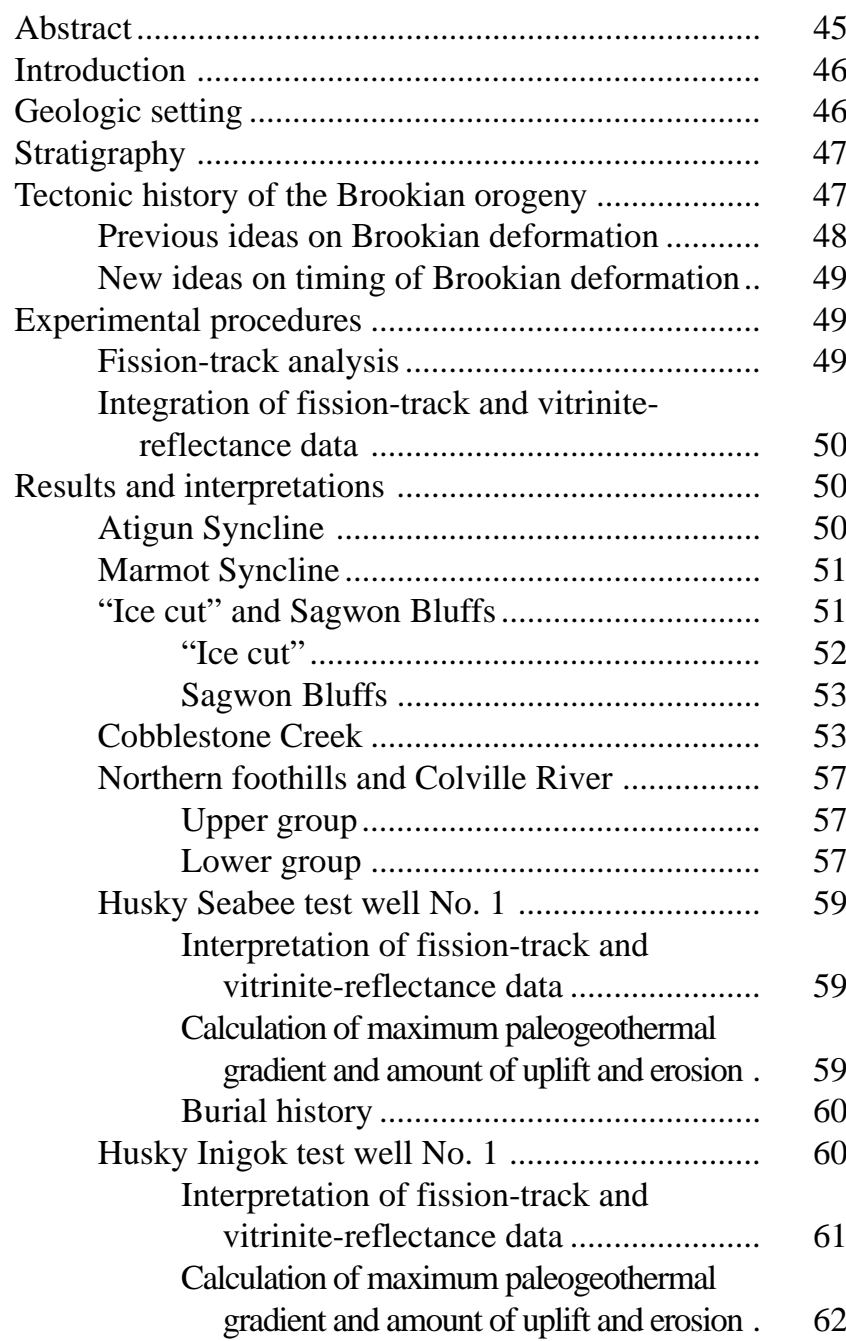

Burial history ......................................... 63

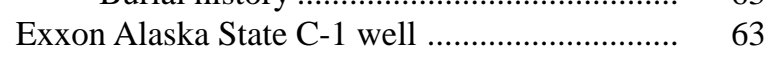

Interpretation of fission-track and vitrinite-reflectance data ................... 63

Calculation of maximum paleogeothermal gradient and amount of uplift and erosion . 64

Burial history ...................................... 64

Cause of elevated paleotemperatures ........................ 65

High temperatures due to elevated heat flow .... 65

High temperatures due to burial ........................ 66

Timing of uplift and erosion ................................... 67

Amounts of uplift and erosion ................................. 68

Regional synthesis ............................................... $\quad 70$

Acknowledgments .................................................. $\quad 70$

References cited ............................................... $\quad 70$

Appendixes:

A. Individual sample information ................... 74

B. Analytical results .................................... 77

\section{ABSTRACT}

Apatite-fission-track data have been generated for 72 outcrop and subsurface samples to evaluate the thermal and tectonic history of the Colville basin in northern Alaska. Data from the outcrop localities and two wells, located in the southern half of the foreland basin, suggest that the rocks were exposed to maximum paleotemperatures in the Late Cretaceous to early Paleocene as a result of burial by Late Jurassic and Cretaceous sedimentary rocks. Cooling from these elevated paleotemperatures was affected by two episodes of deformation resulting in uplift and erosion during the Paleocene at $\sim 60 \pm 4 \mathrm{Ma}$ and during the late Oligocene at $\sim 25 \pm 3$ Ma. Data from a well located on the northern flank of the basin suggest that $\sim 15$ to $20^{\circ} \mathrm{C}$ of cooling also occurred during the Miocene at some time between 20 and $10 \mathrm{Ma}$. Little or no evidence, however, exists for removal of any stratigraphic section from the well section at that time. Cooling of the strata in this well, therefore, could reflect a significant 
decrease in the mean annual surface temperature during the Miocene.

\section{INTRODUCTION}

The Colville basin, is a late Mesozoic and Cenozoic basin that spans the entire width of northern Alaska (fig. 1). During the initial stage of the Brookian orogeny in the Late Jurassic through Early Cretaceous, uplift and erosion of the Brooks Range resulted in many kilometers of material being shed from the northward-verging deformed rocks to be rapidly deposited into the adjoining foreland basin (for example, Mull, 1982; Mayfield, Tailleur, and Ellersiech, 1988; Bird and Molenaar, 1992; Moore and others, 1992). Prior to the Cenozoic, uplift and erosion within the Brooks Range and foreland basin ceased for a short period of time (Murphy and O'Sullivan, 1992; Murphy and others, 1994; O'Sullivan, 1993), possibly marking the end of the Brookian orogeny (O'Sullivan, 1993; O'Sullivan and Murphy, unpublished data). Subsequently, the geologic relations across much of the foreland basin have been complicated by at least two episodes of Cenozoic deformation due to renewed advancement of the Brooks Range fold and thrust belt at $\sim 60 \pm 4 \mathrm{Ma}$ and $\sim 25 \pm 3 \mathrm{Ma}$. I suggest that uplift and erosion of the central foreland basin during the Paleocene is likely related to Laramide orogenesis within the Brooks Range (Hubbard and others, 1987) and that late Oligocene uplift and erosion within the foreland basin has been previously unrecognized. Along the northern flank of the foreland basin the geologic relations

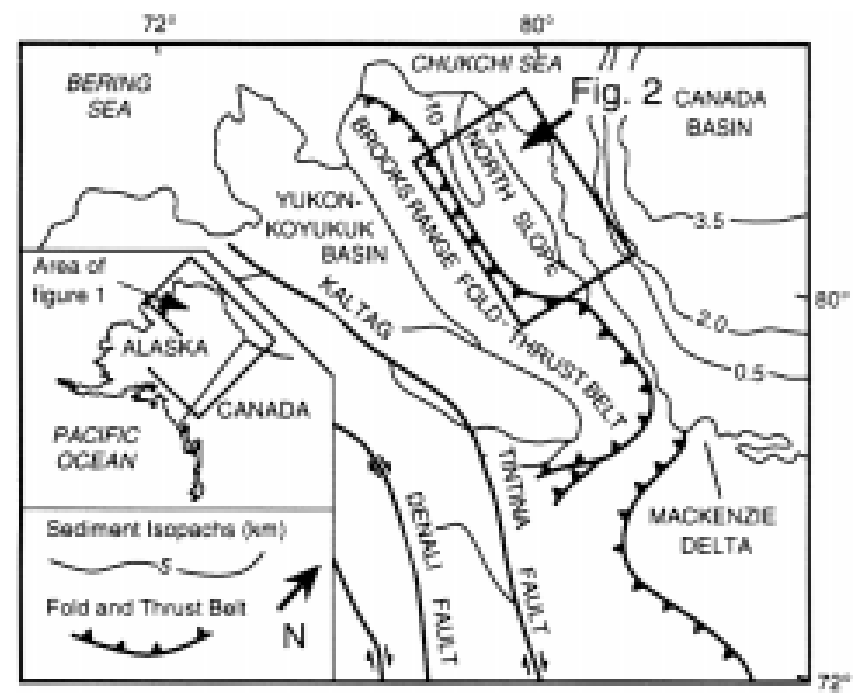

Figure 1. Index map showing general locations of major physiographic provinces across northern Alaska. Tectonic elements of northern Alaskan Cordillera include Colville basin and Brooks Range fold and thrust belt . Region discussed in present study (outlined by the box) is shown in greater detail in figure 2. Heavy lines indicate faults; paired arrows show relative movement. are relatively uncomplicated because the region has not experienced extensive postdepositional deformation.

Besides deformation, the Colville basin also was affected by a severe climatic change at some time during the middle to late Cenozoic (Clark, 1982, 1990). Mean annual surface temperatures decreased during the Miocene, from temperate conditions in the Late Cretaceous to Eocene $\left(\sim 5^{\circ} \mathrm{C}\right.$; Spicer, 1987) to present-day arctic conditions $\left(<-5^{\circ} \mathrm{C}\right.$; Lachenbruch and others, 1988). This cooling complicates calculations that estimate the amount of Tertiary uplift and erosion (O'Sullivan, unpublished data).

Fission tracks from detrital apatites within sedimentary sequences record the low temperature (less than $\sim 120^{\circ} \mathrm{C}$ ) thermal history of the host rock (Gleadow and others, 1983, 1986; Gleadow and Duddy, 1984; Green, Duddy, Gleadow, and Lovering, 1989; Green, Duddy, Laslett, and others, 1989). It has been shown that for times on the order of millions of years, fission-track ages and the length of confined fission tracks are reduced by temperatures between $\sim 60^{\circ}$ and $120^{\circ} \mathrm{C}$ (Gleadow and others, 1983; Green and others, 1986). The reduction of confined fission-track lengths leads to a reduction of the apparent fission-track age. In addition, the distribution of the confined track lengths in an apatite directly reflects the thermal history of a sample (Gleadow and others, 1986; Green, Duddy, Gleadow, and Lovering, 1989; Green, Duddy, Laslett, and others, 1989). By combining both age and confined fission-length measurements, apatite-fissiontrack data provide not only estimates of maximum temperatures and the time of cooling from maximum temperatures (Gleadow and others, 1983; Green, Duddy, Gleadow, and Lovering, 1989) but also allow determination of the thermal history (time-temperature path) experienced by the host rock (for example, Zeitler, 1985; Omar and others, 1989; Green, 1989; Green, Duddy, Laslett, and others, 1989).

This paper presents analytical results and interpretations of an apatite-fission-track study of 72 samples from Mississippian through Tertiary sedimentary strata from the central part of the North Slope foreland basin of Alaska (fig. 2 ). The purpose here is to present and interpret new apatitefission-track data to constrain and model the thermotectonic history of the central part of the foreland basin. Companion studies of the thermotectonic history of the northeastern part of the foreland basin in the Arctic National Wildlife Refuge (ANWR) and the Mackenzie Delta can be found in O'Sullivan, Green and others (1993), O'Sullivan and others (1992) and McMillen and O'Sullivan (1992).

\section{GEOLOGIC SETTING}

Northern Alaska contains two principal geographic features, the Brooks Range fold and thrust belt and the North Slope (fig. 1). The Brooks Range consists of rugged, linear mountain ranges, ridges, and hills that rise to over 3,000 $\mathrm{m}$ in the east but decrease progressively in maximum altitude and 
relief toward the west (Mull, 1982; Mayfield, Tailleur, and Ellersiech, 1988; Moore and others, 1992). The Brooks Range generally trends east-west throughout the North Slope but bends east-northeast in eastern Alaska and then curves to the southeast in northwestern Canada. The lack of any obvious older surfaces (peneplains) throughout the Brooks Range suggests that the range is quite young.

The North Slope, including the Colville foreland basin, extends northward from the drainage divide at the crest of the Brooks Range to the Arctic Ocean coastline (Bird and Molenaar, 1992). The southern part of the Colville basin consists of the foothills of the Brooks Range, which are a series of east-trending rolling hills and ridges. North of the foothills, the northern part of the Colville basin is characterized by marshland with little or no relief. The northern boundary of the basin approximately coincides with the northern Alaska coastline where it meets the Beaufort Sea. The Barrow Arch separates the Colville basin to the south from the Canada Basin to the north.

\section{STRATIGRAPHY}

The sedimentary rock record of the North Slope of Alaska has been previously described in great detail by many authors (for example, Brosge and Tailleur, 1970; Lerand, 1973; Detterman and others, 1975; Palmer and others, 1979;
Grantz and May, 1983; Smith, 1987; Hubbard and others, 1987; Bird and Molenaar, 1987, 1992). This paper follows the major sequences (depositional packages bounded by major unconformities) used by Hubbard and others (1987). Fission-track samples were only collected from three sequences: (1) the Ellesmerian sequence, (2) the Beaufortian sequence, and (3) the Brookian sequence. A generalized stratigraphic column showing the names and stratigraphic ages of the units sampled is shown in figure 3.

\section{TECTONIC HISTORY OF THE BROOKIAN OROGENY}

The Late Jurassic to early Tertiary(?) Brookian orogeny is inferred to represent southward subduction of the Arctic Alaska passive margin beneath the intra-oceanic Koyukuk Arc, resulting in the Middle Jurassic collision of "Pacific realm" exotic terranes with Arctic Alaska (Richter and Jones, 1973; Roeder and Mull, 1978; Box, 1985; Box and Patton, 1987). Rifting of the Arctic Alaska Plate to the north of the North Slope during the Late Jurassic and Early Cretaceous formed the proto-Canada Basin. During the Neocomian, further uplift and erosion of the rifted margin resulted in the formation of the regional Lower Cretaceous unconformity on which Brookian sequence rocks were subsequently deposited (Mull, 1982; Smith, 1987; Hubbard and others, 1987).

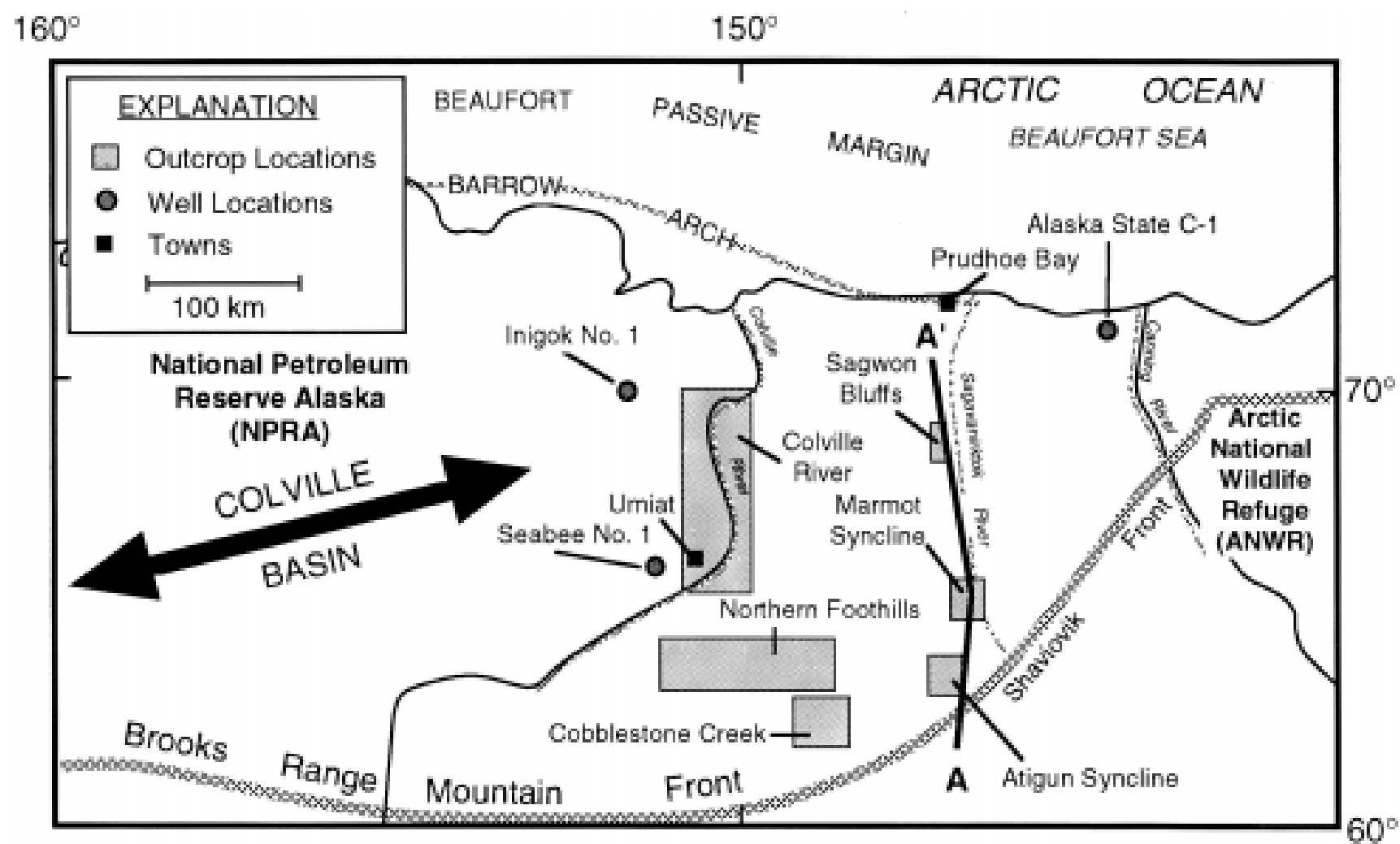

Figure 2. Regional map of northern central Alaska showing locations of outcrops and wells sampled for this study. See figure 19 for section A-A'. 
In response to (1) uplift of the core of the Brooks Range, (2) tectonic loading by the stacked allochthons, and (3) the resulting flysch deposition, rapid subsidence of the asymmetric Colville basin occurred (Mull, 1982, 1985; Smith, 1987).

\section{PREVIOUS IDEAS ON BROOKIAN DEFORMATION}

The Brookian orogeny has been previously divided into two major episodes - an early episode during the Late Jurassic to Early Cretaceous and a late episode during the Late Cretaceous and early Tertiary(?) (Moore and others, 1992, and references therein). The early Brookian orogenic phase was characterized by the emplacement of relatively far-traveled thrust sheets and uplift of the core of the Brooks Range during the Late Jurassic to Neocomian (Roeder and Mull, 1978; Box, 1985; Mayfield, Tailleur, and Ellersiech, 1988). Continued northward compression and collapse of the southfacing continental margin led to emplacement of regionally extensive stacked allochthons in the western and central
Brooks Range representing estimated crustal shortening of between 400 and 600 km (Rattey, 1987; Mayfield, Tailleur, and Ellersiech, 1988). The late Brookian orogenic phase was characterized by gentle long-wavelength folding of Lower Cretaceous and younger strata and emplacement of thrust faults displaying relatively smaller amounts of shortening than occurred in the early Brookian orogenic phase (Moore and others, 1992, and references therein). The younger structures overprint features developed during the early Brookian phase, characterize rocks of the northern foothills, and extend northward under the North Slope (Moore and others, 1992).

Timing of the early orogenic phase is based on K-Ar radiometric dates (dates range between $\sim 170$ to $\sim 55 \mathrm{Ma}$ with a peak at $\sim 110 \mathrm{Ma}$ ) of metamorphic rocks and reset $\mathrm{K}-\mathrm{Ar}$ ages of Devonian granitic plutons (Turner and others, 1979; Dillon and others, 1980, 1987) together with age constraints on major regional folding and faulting of the allochthons (Mull, 1982, 1985). Several kilometers of uplift and erosion resulted from a combination of contraction, extension, and isostatic rebound, which was probably a consequence in large

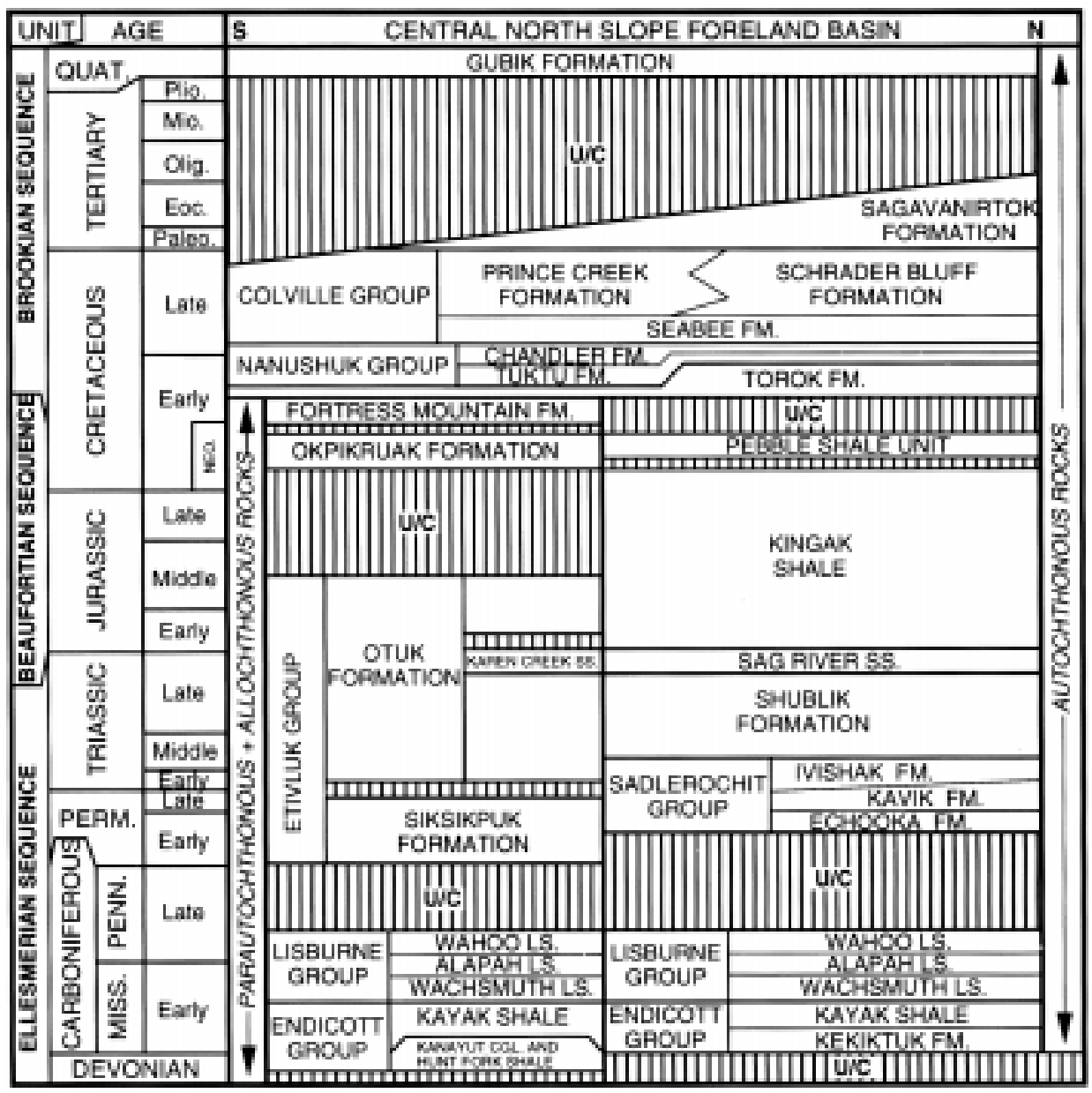

Figure 3. Generalized stratigraphy of the Colville basin (modified after Detterman and others, 1975; Mull, 1982; Mull and Adams, 1989; Hubbard and others, 1987). Shaded areas represent unconformities. Quat., Quaternary; Plio., Pliocene; Mio., Miocene; Olig., Oligocene; Eoc., Eocene; Paleo. Paleocene; Neo., Neocomian; Penn., Pennsylvania; and Miss., Mississippian. 
part of crustal thickening during early deformation (Mull, 1982; Gottschalk and Oldow, 1989).

\section{NEW IDEAS ON TIMING OF BROOKIAN DEFORMATION}

Before the recent application of fission-track studies in the area, it was impossible to directly constrain the timing of post-Albian deformation because of the lack of crosscutting relationships. O'Sullivan and others (1991b) and Murphy and others (1994) suggest that the central Brooks Range experienced an episode of rapid cooling related to kilometer-scale uplift and erosion during the Albian at $\sim 100 \pm 3 \mathrm{Ma}$ (all errors from fission-track data reported at $\pm 2 \sigma$ ) after which no largescale cooling events are recorded for $\sim 40$ m.y. Then starting in the Paleocene, a sequence of rapid uplift and erosion episodes are recorded. Timing of a Paleocene-age orogenic phase ( $60 \pm 4 \mathrm{Ma})$, which affected the entire Brooks Range, is based on fission-track data and interpretations completed by Murphy and O'Sullivan (1992, and unpub. data), Murphy and others (1994), O'Sullivan (1988, 1991, 1993), O'Sullivan and Decker (1989), O'Sullivan and others (1990), and O'Sullivan, Green and others (1993). During the Eocene and early Oligocene, at $\sim 43 \pm 3 \mathrm{Ma}$ and $\sim 34 \pm 3 \mathrm{Ma}$, respectively, the northeastern Brooks Range experienced rapid cooling related to episodes of uplift and erosion (McMillen and O'Sullivan, 1992; O'Sullivan, 1993; O'Sullivan, Green and others, 1993). Furthermore, the results of O'Sullivan and others (1991a, 1992, in press) indicated that uplift and erosion of the Brooks Range occurred as recently as the late Oligocene $(\sim 25 \pm 3 \mathrm{Ma})$ in the Mt. Doonerak anticlinorium and the northeastern Brooks Range.

Based on the available fission-track data, it is believed by some (for example, O’Sullivan, 1993; Murphy and O'Sullivan, unpub. data) that rapid uplift and erosion within the Brooks Range during the Albian possibly marked the end of the Brookian orogeny. If this is true then subsequent Paleocene deformation due to renewed advancement of the Brooks Range fold and thrust belt is possibly related to Laramide orogenesis as proposed by Hubbard and others (1987). At this time, it is not clear whether the late Oligocene deformation in the core of the Brooks Range is related to continued Laramide deformation or to a new orogenic episode. Following the reconstructions of plate movements during the Tertiary by Engebretson and others (1985), however, it is probable that deformation in the Brooks Range has continued throughout the Tertiary in response to continued subduction of the Pacific Plate beneath Alaska. Therefore, Laramide deformation has possibly continued in northern Alaska long after the Pacific and North American plate boundary along the western coast of North America changed from compressive to strike-slip during the Eocene marking the end of Laramide deformation.

\section{EXPERIMENTAL PROCEDURES}

\author{
FISSION-TRACK ANALYSIS
}

Fission-track analyses were carried out in the laboratories of the Department of Geology at La Trobe University, Melbourne, Australia. A description of the methodology used for sample preparation and fission-track counting has been described in detail by Naeser (1979) and Gleadow (1984). Lengths of confined fission tracks (Lal and others, 1969) were measured using the procedure outlined by Green (1986). Ages were calculated using the standard fission-track age equation using the zeta calibration method (Hurford and Green, 1982, 1983), and uncertainties were calculated using the techniques outlined by Green (1981). A spread in individual-grain ages within a sample can result either from inheritance of detrital grains from mixed source areas or from differential annealing in grains of different $\mathrm{F}-\mathrm{Cl}$ composition by heating within a narrow range of temperatures (Green, Duddy, Laslett, and others, 1989). In samples with a significant spread in singlegrain ages, the "conventional analysis" (as defined by Green, 1981) based purely on Poissonian variation is not valid. In cases when the conventional analysis is not valid, which can be detected by using the chi-squared $\left(\chi^{2}\right)$ statistic (Galbraith, $1981)$, the mean age provides a more useful measure of age (Green, 1981). The chi-squared statistic tests the probability that all grains counted belong to a single population of ages. A probability of less than 5 percent is taken as evidence of a significant spread of single-grain ages.

Gleadow and others (1986) and Green, Duddy, Gleadow, and Lovering (1989) and Green, Duddy, Laslett, and others (1989) have explained in detail the principles of interpreting confined fission-track length distributions in apatite. When fission tracks form in apatite, they have a fairly constant mean length of $\sim 16 \mu \mathrm{m}$ (Gleadow and others, 1983, 1986). Following their formation, fission tracks in apatite progressively shorten (anneal) at a rate that depends primarily on temperature (Fleischer and others, 1975; Gleadow and others, 1986; Green, Duddy, Laslett, and others, 1989). Therefore, increased annealing results in shorter tracks, reduced track density, and a reduction in the fission-track age (Gleadow and others, 1986; Green, Duddy, Gleadow, and Lovering, 1989; Green, Duddy, Laslett, and others, 1989). Total annealing results in the reduction of the fission-track age to zero. Because new tracks continuously form throughout geologic time, the distribution of track lengths in an apatite grain reflects the integrated thermal history of the grains' host rock (Green, Duddy, Laslett, and others, 1989).

In this study, apatite-fission-track data have been interpreted using the understanding of apatite-fission-track system response described by Green, Duddy, Laslett, and others (1989). This understanding is based on an empirical kinetic description of laboratory annealing data in Durango apatite (Green and others, 1986; Laslett and others, 1987), employ- 
ing the principle of "equivalent time" described by Duddy and others (1988). In detail, the rate of annealing depends on the chemical composition, with fission tracks in chlorine-rich apatites being slightly more resistant to annealing than fission tracks in fluorine-rich apatites (Green and others, 1985, 1986; Sieber, 1986). Thermal-history interpretations are based on a quantitative treatment of annealing achieved by forward computer modeling (Green, Duddy, Laslett, and others, 1989) of fission-track shortening and age evolution through likely thermal histories for an average apatite composition $(\mathrm{Cl} /$ $(\mathrm{Cl}+\mathrm{F})=\sim 0.1)$, while making appropriate adjustments for the actual $\mathrm{Cl}$ composition likely in each sample. This model by Laslett and others (1987) for annealing of fission tracks in apatite gives predictions that are consistent with geologic constraints on annealing behavior, as explained by Green, Duddy, Laslett, and others (1989). Compilation of the composition of apatites from a variety of sedimentary rocks has shown that the Durango apatite composition is close to the maximum $\mathrm{Cl}$ content in most samples. Predictions based on this composition should slightly overestimate the actual amount of annealing, although in thermal histories resulting from continuous cooling, as in this study, compositional effects play a relatively minor role (Green, Duddy, Laslett, and others, 1989).

The uncertainty in predicted track-length values is approximately 0.25 to $0.5 \mu \mathrm{m}$, which is considered equivalent to an uncertainty in the absolute paleotemperature estimates of about $\pm 10^{\circ} \mathrm{C}$ (Green, Duddy, Laslett, and others, 1989). Errors stemming from variations in apatite composition are generally less than this amount (Green, Duddy, Laslett, and others, 1989). Grains tested from the North Slope foreland basin $(n=145)$ have apatite compositions that are predominantly fluorine-rich ( $\sim 0.0$ to 0.02 weight percent $\mathrm{Cl}$ ) with $\sim 15$ percent of grains ranging between 0.05 and 0.08 weight percent $\mathrm{Cl}$ (O'Sullivan, unpub. data). In the following discussion on data results and interpretation, the corrected geothermal gradient obtained from measured formation temperatures recorded in each well completion report are presented. Estimates of subsurface equilibrium temperatures are prone to error, but errors of $\pm 10^{\circ} \mathrm{C}$ would not radically alter the conclusions of this study.

\section{INTEGRATION OF FISSION-TRACK AND VITRINITE-REFLECTANCE DATA}

Though such data provide no constraints on timing of maximum paleotemperatures, independent vitrinite reflectance $\left(R_{\mathrm{o}}\right)$ values may be used as an indicator of maximum paleotemperature (Lopatin, 1971; Waples, 1980; Burnham and Sweeney, 1989). Using the model proposed by Burnham and Sweeney (1989, equation No. 2), a sample which has been exposed to a maximum temperature of $110^{\circ} \mathrm{C}$ for $\sim 10 \mathrm{~m} . \mathrm{y}$. (adequate to totally anneal fission tracks in most apatite) would have an $\mathrm{R}_{\mathrm{o}}$ value of $\sim 0.7$ percent. Therefore, as an approxi- mation, an $R_{o}$ value of $\geq 0.7$ percent could be used to indicate whether or not a sample has been exposed to elevated temperatures $\left(>110^{\circ} \mathrm{C}\right)$ for the length of time necessary to reset the apatite-fission-track age.

After maximum paleotemperatures estimates from fission-track and vitrinite-reflectance data are determined for samples from a vertical sequence, plotting these values relative to depth provides a maximum paleotemperature profile from which a paleogeothermal gradient at the time of maximum paleotemperatures can be estimated (Bray and others, 1992). In a vertical section that has been hotter in the past, the paleogeothermal gradient can be compared to the presentday geothermal gradient, thus allowing for the interpretation of the cause of the high paleotemperatures and the cause of the subsequent cooling to the present temperatures. The amount of removed section can be estimated by dividing the degree of cooling (calculated by estimating the maximum paleotemperature value at the surface and subtracting the mean annual surface temperature at the time the section began to cool from maximum paleotemperatures) by the geothermal gradient.

If the surface temperature at the time the section began to cool from maximum temperatures is not known (and thus the present surface temperature is used to calculate the total degree of cooling) the amount of section removed since maximum paleotemperatures were reached will be too high by a value referred to as the "apparent" uplift and erosion (O'Sullivan, 1993). Apparent uplift and erosion is defined as the amount of section which would have had to have been removed by uplift and erosion to explain the total amount of cooling, although in reality the cooling was in response to a decrease in the mean annual surface temperature. If the mean annual surface temperature at the time cooling began is known, the apparent uplift and erosion can be calculated by subtracting the present mean annual surface temperature from the previous mean annual surface temperature and dividing by the geothermal gradient.

\section{RESULTS AND INTERPRETATIONS}

Sample details including depth, formation name, stratigraphic age, and apatite yield are summarized in appendix A. All samples, each weighing between $\sim 1$ to $2 \mathrm{~kg}$, were from Lower Mississippian to Tertiary sand-dominated intervals. Apatite-fission-track analytical results are given in appendix B. Basic counting data, individual crystal ages, etc. are available in O'Sullivan (1993).

\section{ATIGUN SYNCLINE}

Apatite ages plotted against elevation and stratigraphic age show that throughout the section, all fission-track ages ( 45 to $75 \mathrm{Ma}$ ) are much less than the stratigraphic ages (>105 
Ma; fig. 4). This indicates that a great deal of age reduction has occurred since deposition, an observation which suggests that the samples have been exposed to elevated paleotemperatures after deposition. Inspection of the singlegrain age data from samples with a significant spread in individual-grain ages (denoted by an asterisk (*) in fig. 4) shows that most individual-grain ages are significantly less than the stratigraphic age, but all samples possess a small number of grains with ages similar to or significantly older than the stratigraphic age. These age patterns suggest severe partial annealing at maximum paleotemperatures of $\sim 110^{\circ} \mathrm{C}$ and that elevated paleotemperatures never totally reset the apatite-fission-track age in this sample after deposition. Estimated maximum paleotemperatures between $\sim 110$ and $125^{\circ} \mathrm{C}$ are suggested by an $\mathrm{R}_{\mathrm{o}}$ value of $\sim 0.71$ percent from the Fortress Mountain Formation exposed at Atigun Syncline (Reifenstuhl, 1990). $\mathrm{R}_{\mathrm{o}}$ values of as much as $\sim 1.2$ percent from the same rocks (D. Howell, oral commun., 1993) suggest that maximum paleotemperatures could have reached $\sim 160^{\circ} \mathrm{C}$; however, this temperature is incompatible with the fission-track data, so it is suggested that the high vitrinitereflectance values might have been taken from reworked vitrinite.

Inspection of the single-grain age data from the remaining samples shows that all individual apatite-fission-track ages are much younger than their stratigraphic ages. This suggests that all grains dated were reset after deposition and subsequently cooled from paleotemperatures $\geq 110^{\circ} \mathrm{C}$. The corrected ages for these samples of $\sim 65$ Ma closely approximate the time at which these samples started to cool to temperatures below $\sim 110^{\circ} \mathrm{C}$. Onset of cooling during the earliest Paleocene is also consistent with the reduced grain ages present in the partially annealed samples.

Applying the track annealing model of Laslett and others (1987) to the fission-track data from the Atigun Syncline suggests a protracted, two-stage cooling history (fig. 4). The first episode occurred at some time between $\sim 65$ and $55 \mathrm{Ma}$ and cooled the Atigun Syncline over $\sim 5$ m.y. from maximum paleotemperatures between $\sim 105^{\circ}$ and $110^{\circ} \mathrm{C}$ to between $\sim 50^{\circ}$ and $60^{\circ} \mathrm{C}$. The second episode occurred at some time between $\sim 30$ and $15 \mathrm{Ma}$ and cooled the area $\sim 30^{\circ} \mathrm{C}$ from paleotemperatures between $\sim 50^{\circ}$ and $60^{\circ} \mathrm{C}$ over $\sim 5$ m.y. A two-stage model for cooling is suggested by the presence of the definite peak of confined fission-track lengths of $\sim 14$ $\mu \mathrm{m}$ in each sample. If cooling was continual from the onset (from $\sim 65 \mathrm{Ma}$ to present) then the distribution would be more skewed towards shorter tracks, as the sample would have spent more time at higher temperatures.

\section{MARMOT SYNCLINE}

Apatite-fission-track ages plotted against elevation and stratigraphic age show that throughout the section, all fission-track ages ( 40 to $70 \mathrm{Ma}$ ) are much less than the strati- graphic ages (>90 Ma; fig. 5). Inspection of the single-grain age data from the samples which did not contain a significant spread in individual-grain ages shows the individual fission-track ages are much younger than their stratigraphic ages indicating a great deal of reduction of fission-track ages has occurred following deposition. Because all grains from each mount represented a single population, all apatite grains dated were reset after deposition and subsequently cooled from paleotemperatures $>110^{\circ} \mathrm{C}$. Estimated maximum paleotemperatures between $\sim 115^{\circ}$ and $130^{\circ} \mathrm{C}$ are also suggested by a $\mathrm{R}_{\mathrm{o}}$ value of $\sim 0.72$ percent from the Nanushuk Group exposed at Marmot Syncline (Reifenstuhl, 1990).

Inspection of the single-grain age data from the Marmot Syncline sample with a significant spread in individual-grain ages (sample 98; fig. 5) shows that many grain ages ( 40 to $70 \mathrm{Ma})$ are significantly less than the stratigraphic age, but that there are some grains with fission-track ages similar to or significantly older than the stratigraphic age (fig. $5 C$ ). As was the case with the data from Atigun Syncline, this age pattern suggests severe partial annealing at maximum paleotemperatures between $\sim 105^{\circ}$ to $110^{\circ} \mathrm{C}$ and that these paleotemperatures never totally reset the apatitefission-track age in this sample after deposition. The unreset grains in sample 98 are more chlorine rich (>0.05 percent) and have retained fission tracks at higher temperatures that annealed all tracks in the more fluorine rich grains (O'Sullivan, unpub. data).

Applying the track annealing model of Laslett and others (1987) suggests that good matches to the measured data are obtained with a two-stage cooling history similar to that which has been proposed for the Atigun Syncline. The first cooling episode occurred at some time between $\sim 60$ and $50 \mathrm{Ma}$ and cooled the Marmot Syncline area from maximum paleotemperatures of $\sim 120^{\circ} \mathrm{C}$ to between $\sim 50^{\circ}$ and $60^{\circ} \mathrm{C}$ over $\sim 5$ m.y. The second episode occurred at some time between $\sim 30$ and $15 \mathrm{Ma}$ and cooled the area $\sim 30^{\circ}$ to $40^{\circ} \mathrm{C}$ from paleotemperatures between $\sim 50^{\circ}$ and $60^{\circ} \mathrm{C}$ over $\sim 5$ m.y. Data from sample 98 suggests that when the sample experienced maximum paleotemperatures not all fission tracks were totally annealed.

\section{“ICE CUT” AND SAGWON BLUFFS}

Apatite-fission-track ages plotted against elevation and stratigraphic age show that the apatite-fissiontrack age of the "Ice cut" sample (sample 22, 44 Ma) is much less than its stratigraphic age (>90 Ma), whereas fission-track ages from the Sagwon Bluffs $(\sim 70$ to $75 \mathrm{Ma})$ are all older than or within \pm 2 s error of their stratigraphic ages ( $\sim 35$ to $65 \mathrm{Ma}$; fig. 6$)$. 
"ICE CUT"

The "Ice cut" refers to a large road cut along the Dalton Highway named for massive permafrost ice uncovered when the road was built. Individual-grain ages from sample 22 are consistent with a single-age population. Because the measured fission-track age is much younger than the stratigraphic age, this suggests that all grains dated were reset after depo-
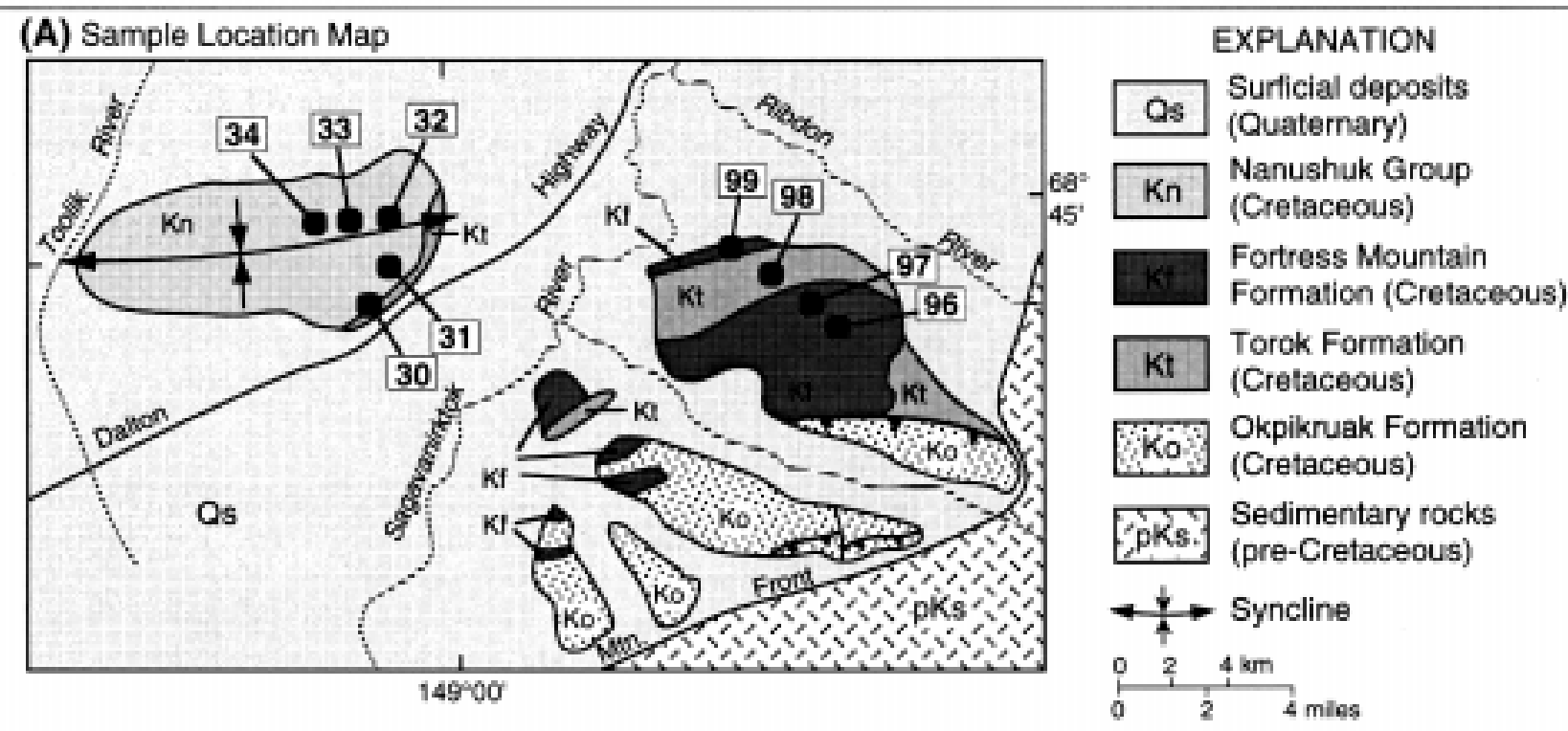

(B) Fission-Track Age and Stratigraphic Age

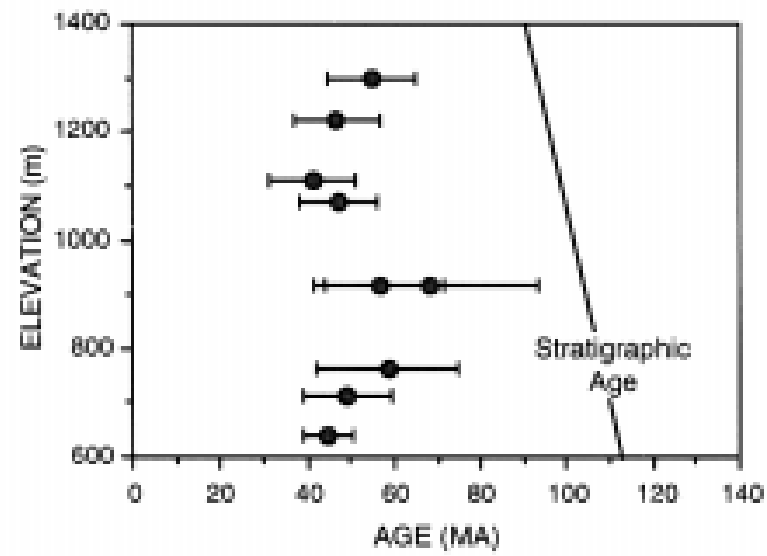

(D) Thermal History

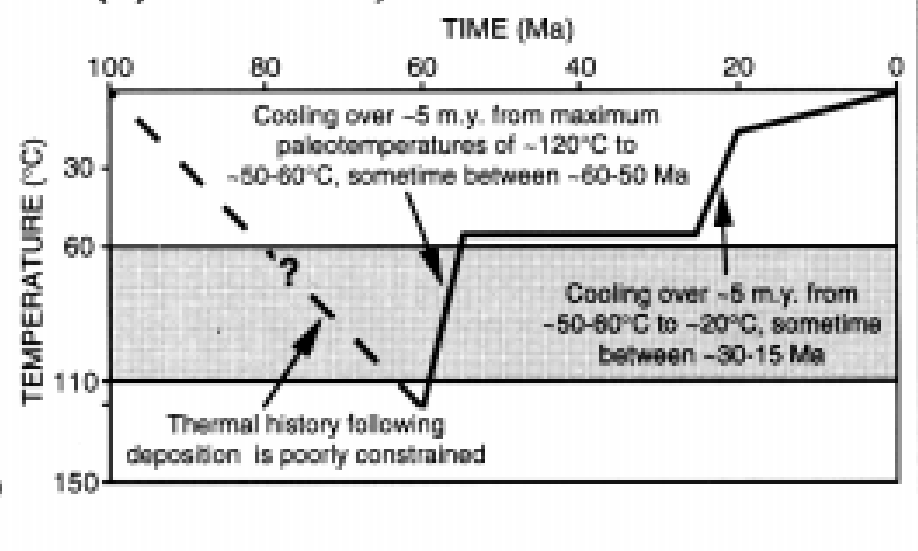

(C) Fission-Track Age and Length Data " Failed Chi squared test
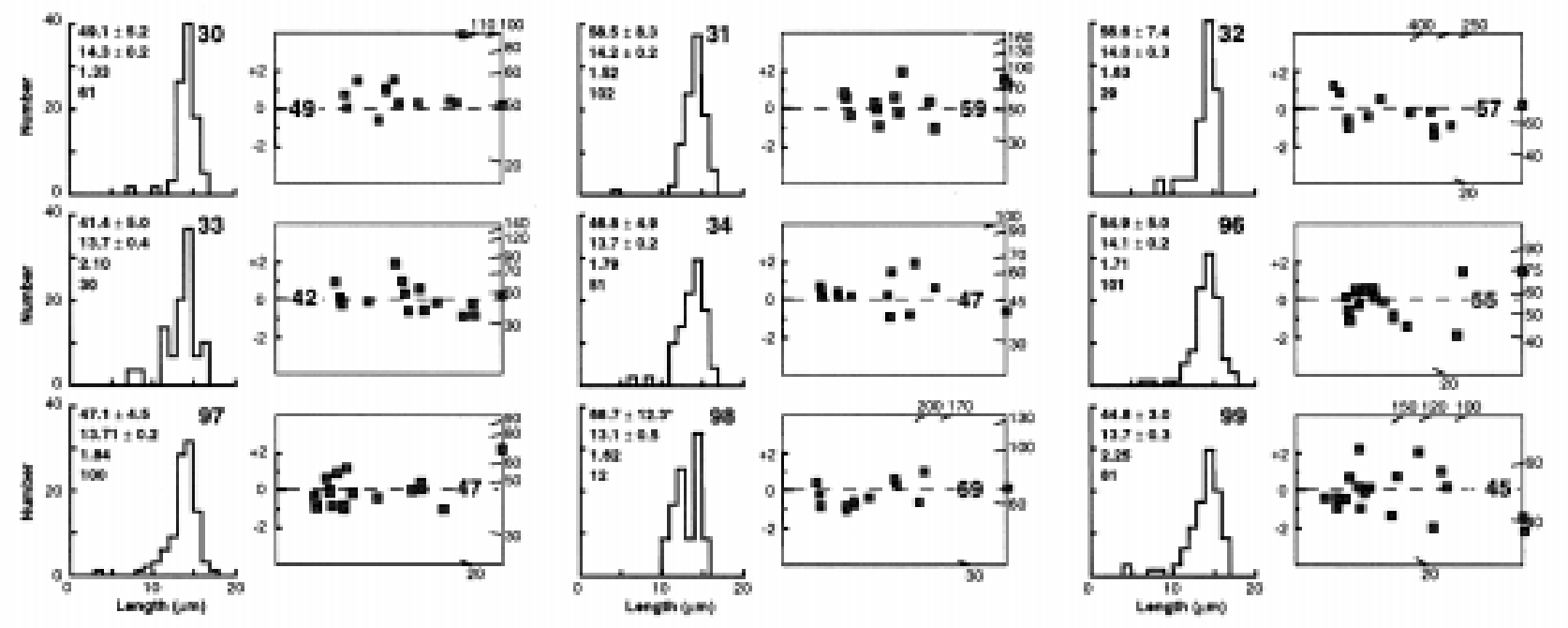
sition and subsequently cooled from paleotemperatures of $>110^{\circ} \mathrm{C}$. Estimated maximum paleotemperatures between $\sim 120^{\circ}$ and $135^{\circ} \mathrm{C}$ are suggested by a $\mathrm{R}_{0}$ value of $\sim 0.75$ percent from rocks exposed in the "Ice cut" (Johnsson and others, 1992). Therefore, it is clear that sample 22 has been subjected to paleotemperatures sufficient to produce total fission-track annealing following deposition and that the fission-track age is a cooling age.

Applying the track annealing model of Laslett and others (1987) to the fission-track data for sample 22 suggests that cooling from temperatures above $\sim 60^{\circ}$ to $110^{\circ} \mathrm{C}$ over $\sim 10$ m.y. occurred at some time between $\sim 60$ and 50 Ma. Furthermore, the data is best modeled if the sample experienced a second discrete episode of cooling at some time between $\sim 30$ and $15 \mathrm{Ma}$ which cooled the area $\sim 40^{\circ}$ to $50^{\circ} \mathrm{C}$ from paleotemperatures between $\sim 50^{\circ}$ and $60^{\circ} \mathrm{C}$ over $\sim 5$ m.y.

\section{SAGWON BLUFFS}

Inspection of the single-grain age data from the Sagwon Bluffs shows that all samples have a significant spread in individual-grain ages, which is inconsistent with a single-age population, and that a number of individual grains give well defined fission-track ages which are indistinguishable from the stratigraphic age (fig. 6). This coincidence in ages could suggest (1) the presence of grains that had not accumulated any fission tracks at the time of deposition, either from contemporaneous volcanism or a rapidly uplifted source terrane, and that subsequently have not been annealed, (2) these grains were totally reset soon after deposition, owing to exposure to elevated temperatures, or (3) these grain-ages were originally

Figure 4. Composite figure showing (A) sample location map (numbers in boxes are sample numbers, map modified after Mull and Adams, 1989), (B) relation between fission-track age, stratigraphic age, and elevation (error bars are $\pm 2 \sigma$ ), (C) representative fission-track data, and (D) generalized best-fit timetemperature history for Atigun Syncline data set. Prefix of sample numbers (89POS or 88POS) has been left off this and subsequent figures. Representative fission-track data includes histograms of fission-track length distributions and radial plots showing single grain ages. Information shown with each fission-track length distribution includes fission-track age $( \pm 1 \sigma)$, mean confined-track length $( \pm 1 \sigma)$, standard deviation, and number of confined tracks measured. Radial plots (Galbraith, 1988) show apatite fission-track age estimates for grains from an individual sample. Each estimate has unit standard error on the $y$-axis, its actual precision is indicated on the $\mathrm{x}$-axis, and its age is indicated by extrapolating a line from the origin through the plotted point. Dashed line shows the mean age of the sample in millions of years. An asterisk (*) denotes a sample that contains multiple-grain-age populations. Track length distributions are normalized to 100 tracks (listed as "Number" on the track-length distributions). On the radial plots the horizontal distance away from the $y$-axis is the relative precision of the individual grain analysis, the vertical axis shows the age and $\pm 2 \sigma$ error for each single grain when projected to the radial age scale on the right. older than the stratigraphic ages and have been partially reset after deposition. The presence of long mean track lengths $(>14$ $\mu \mathrm{m})$ and fission-track ages that are older than their stratigraphic ages suggests these samples were not subjected to temperatures necessary to cause accelerated annealing following deposition. Estimated maximum paleotemperatures between $\sim 70^{\circ}$ and $80^{\circ} \mathrm{C}$ are suggested by a $\mathrm{R}_{\mathrm{o}}$ value of $\sim 0.46$ percent from the Sagavanirktok Formation exposed at Sagwon Bluffs (Reifenstuhl, 1990). The long confined fission tracks and the low maximum paleotemperature estimate indicates that there was either contemporaneous volcanism or a rapidly uplifted source terrane acting as a source area at the time of deposition. Considering that the grains are rounded to angular, the most likely source was a rapidly uplifted source terrane.

Also within the samples from the Sagwon Bluffs are many individual-grain ages ( $\sim 15$ to $30 \mathrm{Ma}$; fig. 6$)$ that are significantly less than the stratigraphic age, suggesting either that some grains were totally annealed after deposition and record a period of cooling at that time or that these individual grains have been partially annealed after deposition. Microprobe analyses indicate the young grains are predominantly fluorine rich ( $\sim 0.0$ to 0.01 percent chlorine) whereas the older grains are more chlorine rich $(>0.04$ percent; O'Sullivan, unpub. data).

Because samples from the Sagwon Bluffs have not been totally annealed following deposition, individual-grain-age and track-length data provide thermal history information of the provenance terrane. Modeling the fission-track data suggests that rapid cooling of the provenance terrane occurred at some time between $\sim 65$ and $50 \mathrm{Ma}$. It is not possible to obtain a direct estimate of the time at which the Sagwon Bluffs samples began to cool from maximum paleotemperatures after deposition and exposure to maximum temperatures between $\sim 70^{\circ}$ and $80^{\circ} \mathrm{C}$. However, cooling from maximum paleotemperatures at some time between $\sim 30$ and $15 \mathrm{Ma}$ is proposed to account for the presence of $\sim 20$-Ma grains in the samples.

\section{COBBLESTONE CREEK}

Apatite-fission-track ages plotted relative to stratigraphy and stratigraphic age show that at the top of the structural sequence in the Picnic Creek allochthon the fission-track ages between $\sim 80$ to $120 \mathrm{Ma}$ are slightly less than or consistent with the stratigraphic age (fig. 7), whereas lower in the section in the Endicott Mountains allochthon, the fission-track ages decrease to between $\sim 40$ to $55 \mathrm{Ma}$. Inspection of the single-grain age data from the three samples from the Picnic Creek allochthon show a significant spread in individual-grain ages. Most individual-grain ages are significantly less than the stratigraphic age, but each sample contains a small number of grains with fission-track ages similar to or significantly older than the stratigraphic age. These age patterns suggest 

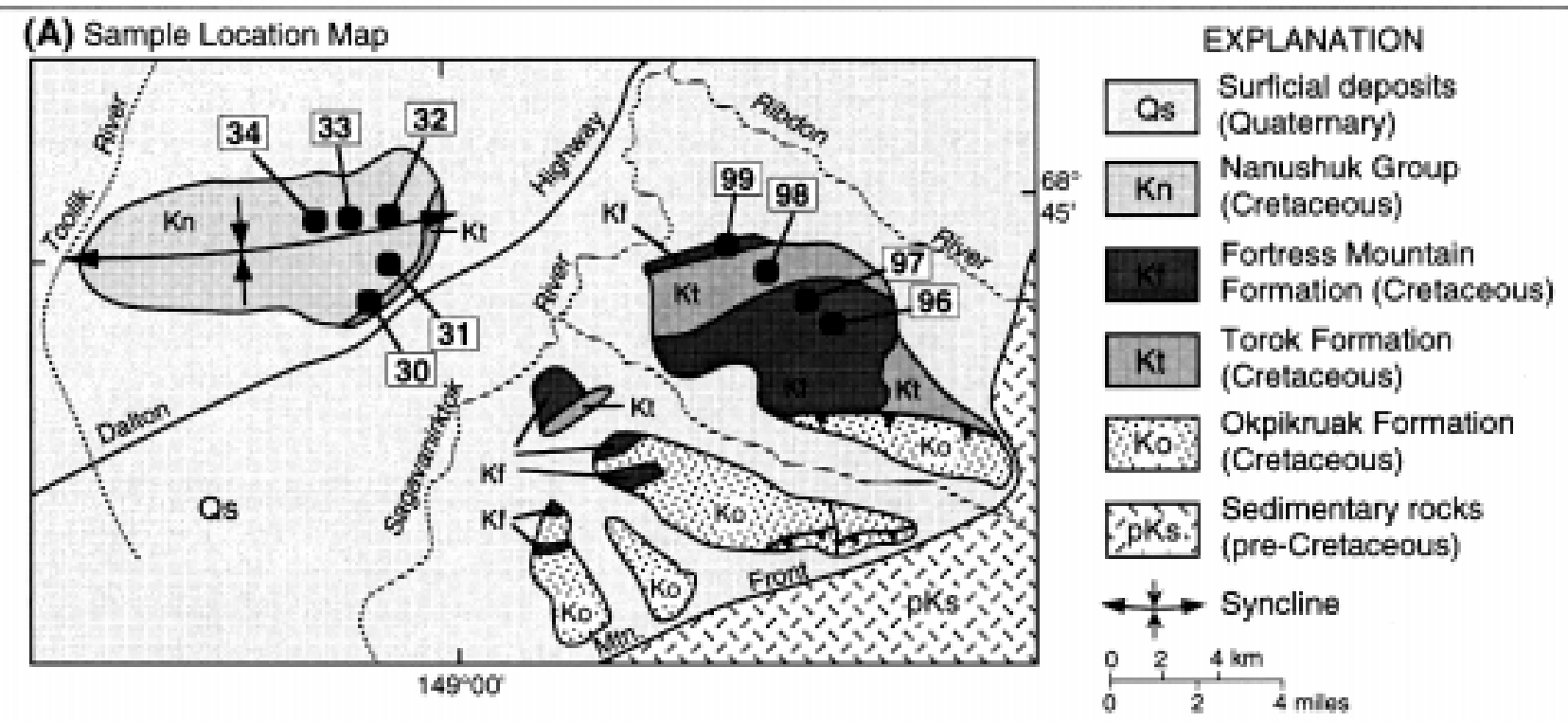

(B) Fission-Track Age and Stratigraphic Age

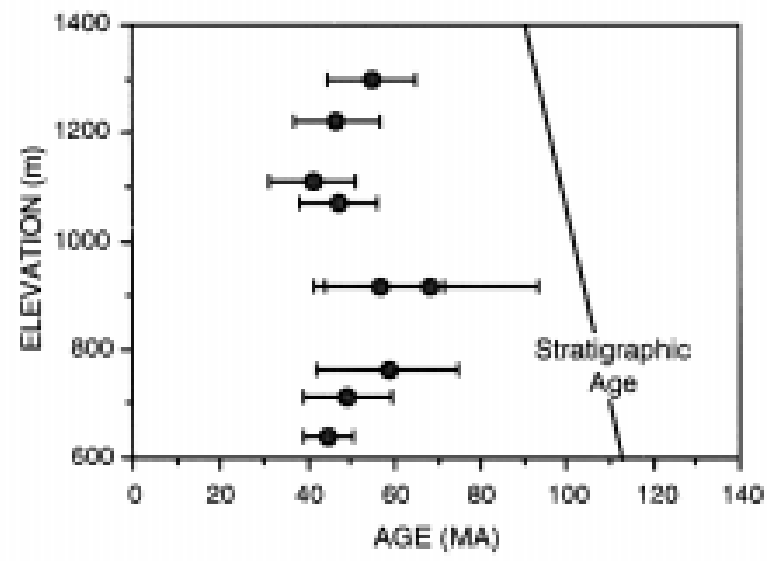

(D) Thermal History

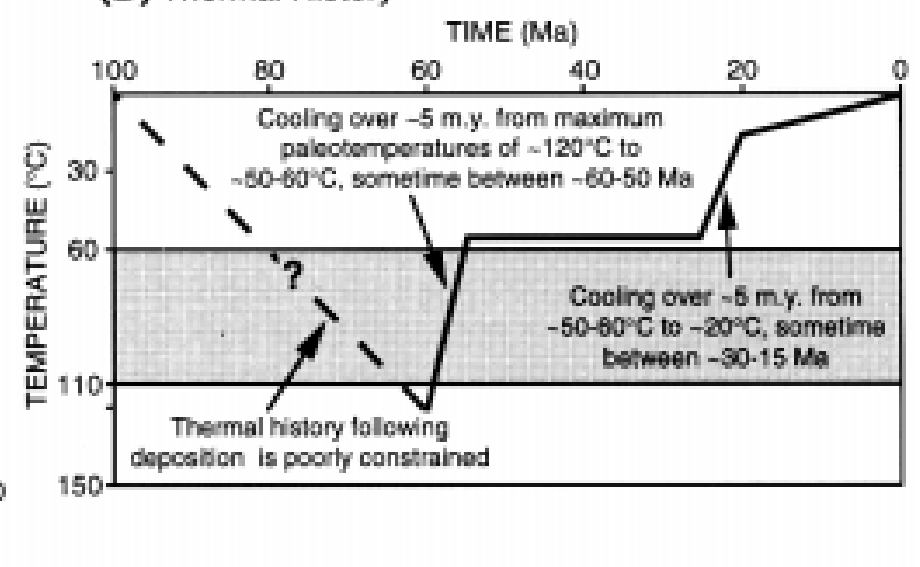

(C) Fission-Track Age and Length Data " Faled Chi squared test
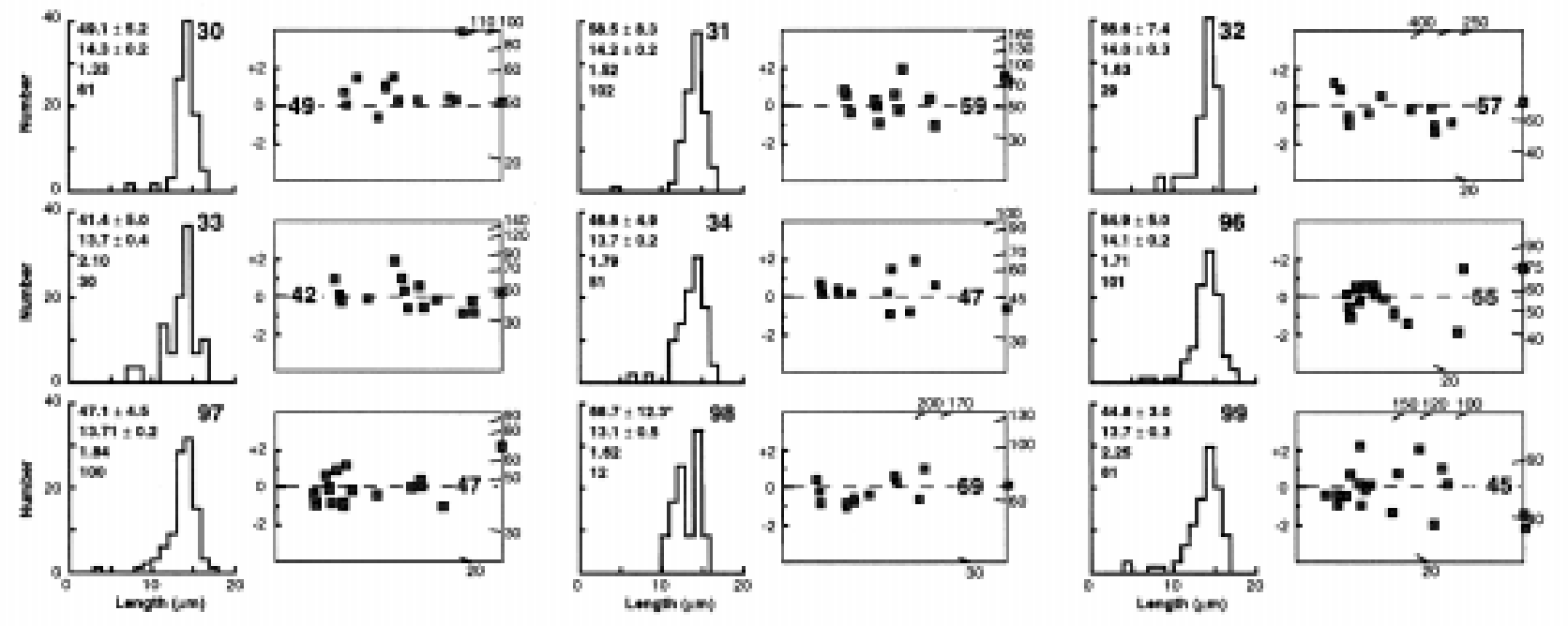

Figure 5. Composite figure showing (A) sample location map (numbers in boxes are sample numbers, map modified after Mull and Adams, 1989), (B) relation between fission-track age, stratigraphic age, and elevation (error bars are $\pm 2 \sigma$ ),

(C) representative fission-track data, and (D) generalized best-fit time-temperature history for Marmot Syncline data set. Representative fission-track data explained in caption of figure 4. 
severe partial annealing at elevated paleotemperatures and that maximum paleotemperatures never exceeded $\sim 110^{\circ} \mathrm{C}$ after deposition. Estimated maximum paleotemperatures between $\sim 90^{\circ}$ and $110^{\circ} \mathrm{C}$ are also suggested by $\mathrm{R}_{\mathrm{o}}$ values between $\sim 0.60$ and 0.70 percent from rocks of the Picnic Creek allochthon near the Cobblestone Creek area (Johnsson and others, 1992).

Inspection of the single-grain age data from each of the remaining four samples from Cobblestone Creek shows individual fission-track ages are all consistent with a single-age

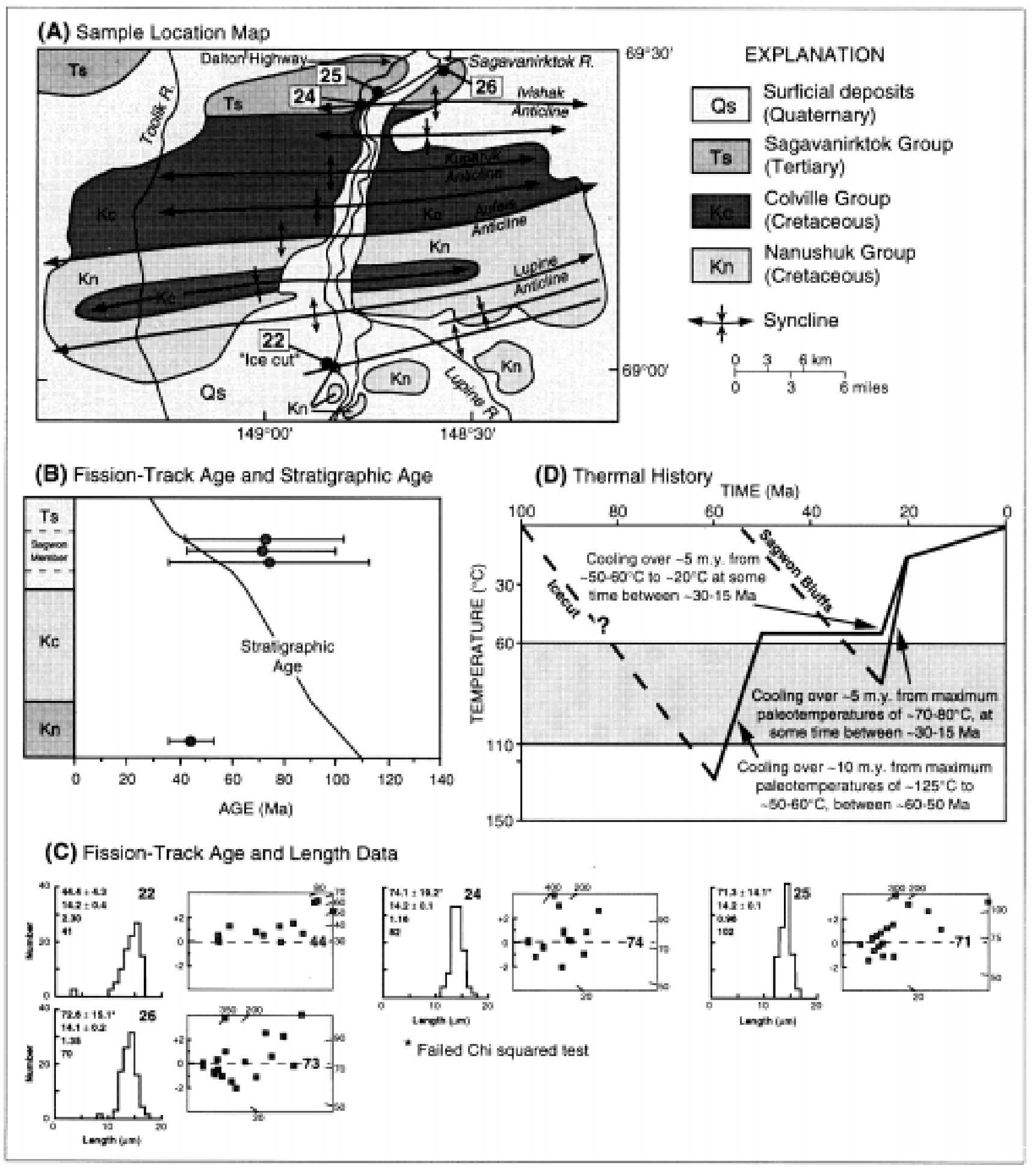

Figure 6. Composite figure showing (A) sample location map (numbers in boxes are sample numbers, map modified after Mull and Adams, 1989), (B) relation between fission-track age, stratigraphy, and stratigraphic age (error bars are $\pm 2 \sigma$ ), (C) representative fission-track data, and (D) generalized best-fit time-temperature history for "Ice cut" and Sagwon Bluffs data set. Representative fission-track data explained in caption of figure 4. 


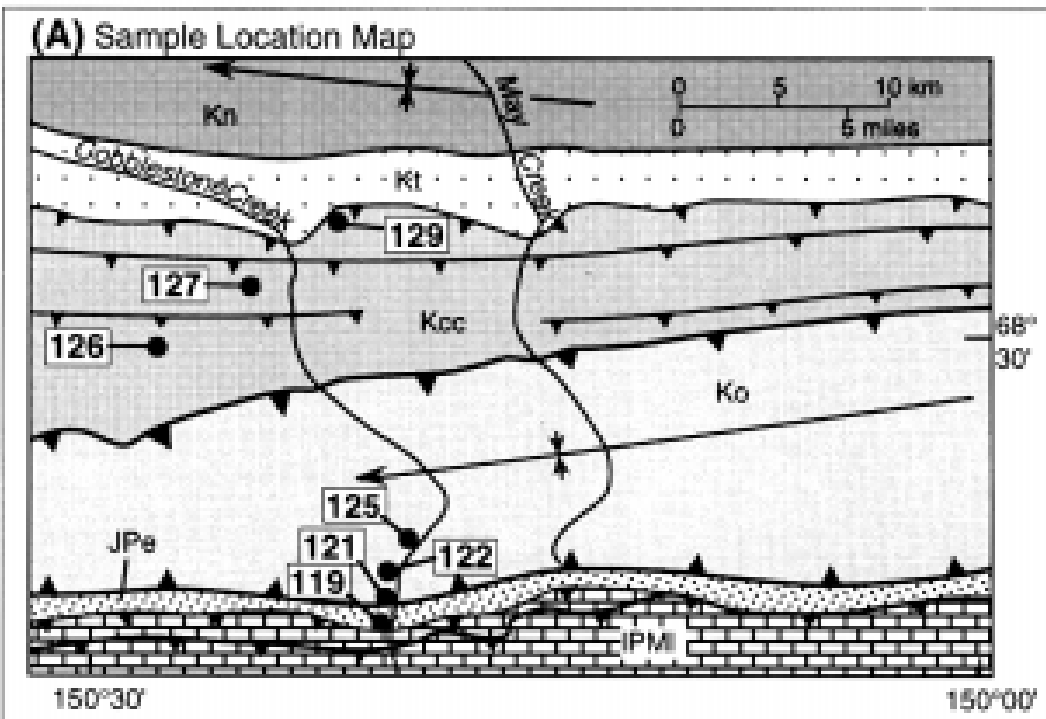

\section{EXPLANATION} AUTOCHTHONOUS ROCKS

Kn Nanushuk Group (Cretaceous)
. Kn'. Torok Formation (Cretaceous)
PICNIC CREEK ALLOCHTHON

Ko Okpikruak Formation (Cretaceous) ENDICOTT MOUNTAINS ALLOCHTHON

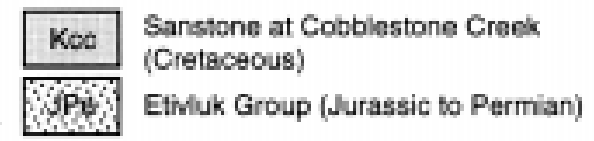

EIPM. Lisburne Group (Pennsylvanian

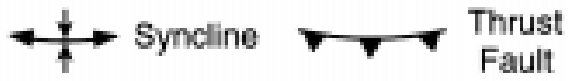

(B) Fission-Track Age and Stratigraphic Age

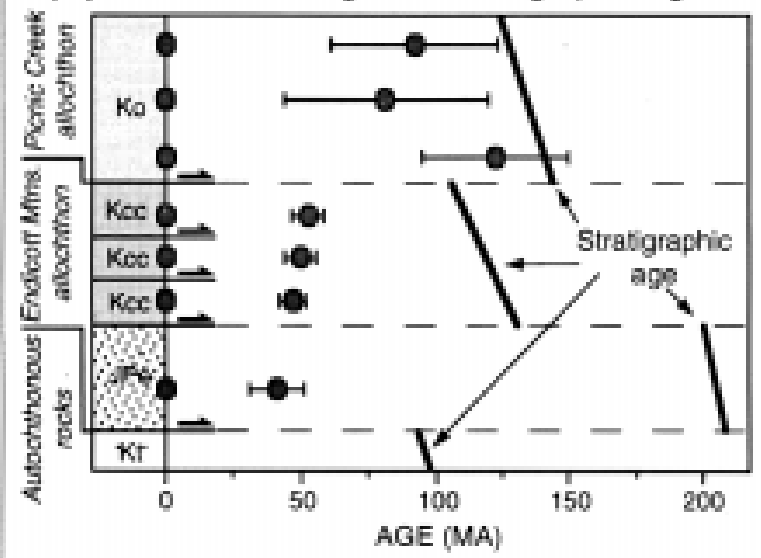

(D) Thermal History

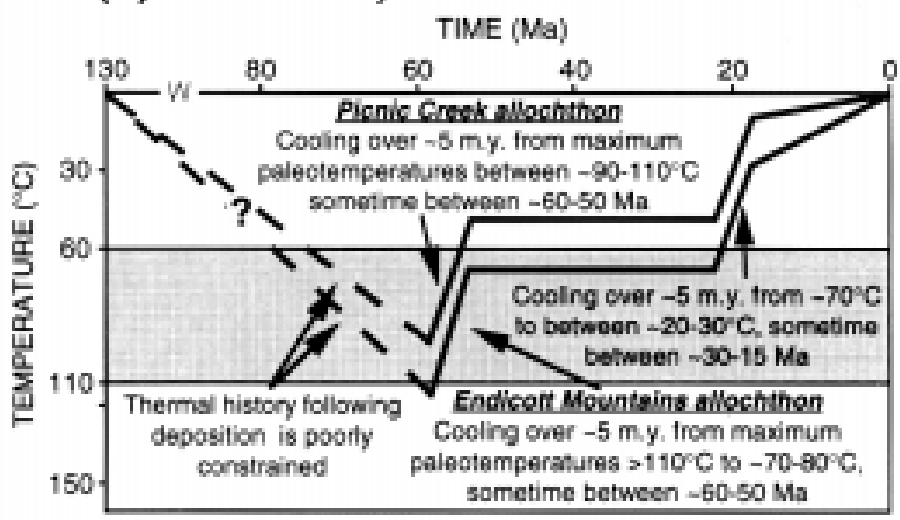

(C) Fission-Track Age and Length Data

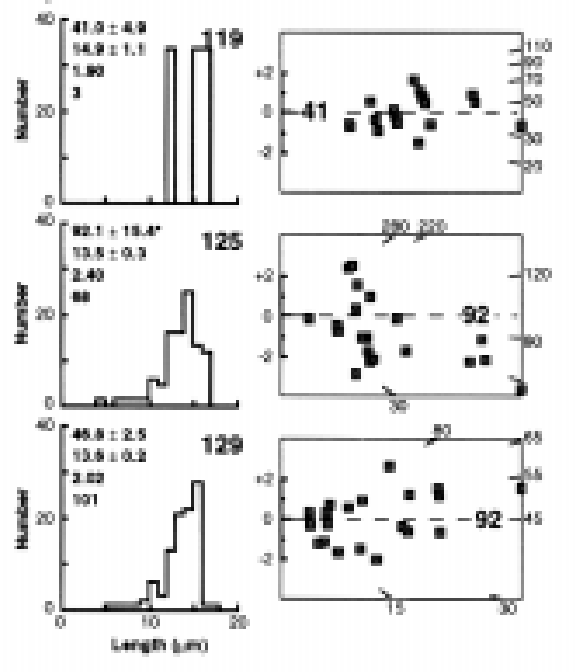

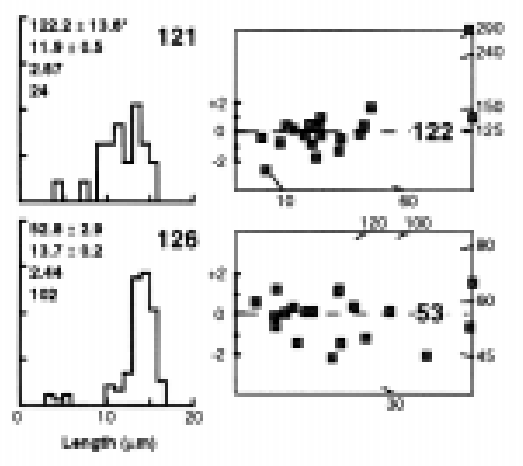

* Failed Chi squared test

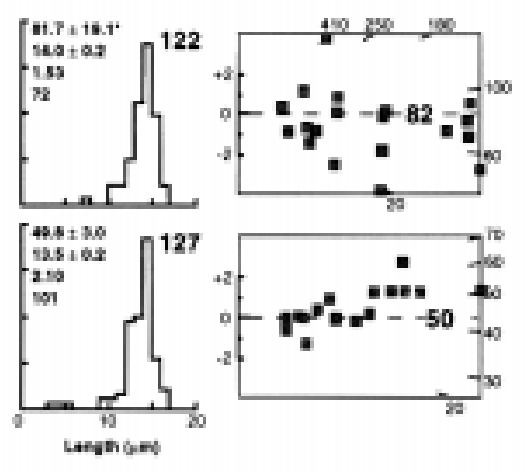

Figure 7. Composite figure showing (A) sample location map (numbers in boxes are sample numbers, map modified after Mull, written commun., 1992), (B) relation between fissiontrack age, stratigraphy, and stratigraphic age (error bars are $\pm 2 \sigma$ ), (C) representative fission-track data, and (D) generalized best-fit time-temperature history for Cobblestone Creek data set. Representative fission-track data explained in caption of figure 4 . 
population. Because the measured fission-track age for each sample is much younger than the stratigraphic age, all grains dated were reset after deposition and subsequently cooled from paleotemperatures of $>110^{\circ} \mathrm{C}$. Therefore, these samples have been subjected to paleotemperatures sufficient to produce total fission-track annealing following deposition, and the fissiontrack ages are cooling ages.

Applying the track annealing model of Laslett and others (1987) to the fission-track data from the Endicott Mountains allochthon suggests a protracted, two-stage cooling history in these samples similar to that which has been proposed for the Marmot Syncline (fig. 7). The first episode occurred at some time between $\sim 60$ and $50 \mathrm{Ma}$ (late Paleocene to early Eocene), and cooled the allochthonous rocks over $\sim 5$ m.y. from paleotemperatures $>110^{\circ} \mathrm{C}$ to between $\sim 70^{\circ}$ and $80^{\circ} \mathrm{C}$. Onset of cooling during the late Paleocene or early Eocene is also consistent with the lowest grain ages present in the partially annealed samples. The second cooling episode occurred at some time between $\sim 25$ and $15 \mathrm{Ma}$ and cooled the Cobblestone Creek area $\sim 30^{\circ}$ to $40^{\circ} \mathrm{C}$ from paleotemperatures between $\sim 70^{\circ}$ and $80^{\circ} \mathrm{C}$ to between $\sim 20^{\circ}$ and $30^{\circ} \mathrm{C}$ over $\sim 5 \mathrm{~m}$.y. The timing of the second cooling episode is supported by the presence of a strong peak of single-grain ages between $\sim 25$ and $15 \mathrm{Ma}$ that is evident in samples 126 and 129 (fig. 7). Modeling of the fission-track data from the overlying samples suggests that the Picnic Creek allochthon experienced the same two-stage cooling history as the Endicott Mountains allochthon except maximum paleotemperatures prior to cooling were between $\sim 90^{\circ}$ to $110^{\circ} \mathrm{C}$ (fig. 7). If, as I have proposed, the Endicott Mountains and Picnic Creek allochthons experienced the same two-stage cooling history, then this suggests that these allochthons were juxtaposed prior to cooling from maximum paleotemperatures.

\section{NORTHERN FOOTHILLS AND COLVILLE RIVER}

Fission-track data from this area fall into two groups (lower and upper groups) on the basis of stratigraphy and apatite-fission-track age. The lower group, with fission-track ages between $\sim 53$ and $\sim 68 \mathrm{Ma}$, includes samples from the Albian to Cenomanian Torok Formation and Nanushuk Group (fig. 8). The upper group, with fission-track ages between $\sim 79$ and $\sim 140 \mathrm{Ma}$, includes samples from the postCenomanian Colville Group and Sagavanirktok Formation.

\section{UPPER GROUP}

Measured fission-track ages from the upper group are older than or are consistent within error with their stratigraphic age. In samples from this group $(n=12)$ a number of individual grains have ages that are indistinguishable from the stratigraphic age (fig. 8). Contemporaneous volcanism is most likely the source of these grains because most of the samples that contain them are from the Colville Group, which contains many tuffaceous and bentonitic layers. Upper group rocks also contain some precise individual-grain ages between $\sim 50$ and $70 \mathrm{Ma}$, ages which are less than the stratigraphic age, suggesting some grains record a period of cooling at that time. The young grains are fluorine rich $(\sim 0.0$ to 0.01 percent) whereas older grains have a higher percentage of chlorine (O'Sullivan, unpub. data). The age pattern for these samples suggests partial annealing at maximum paleotemperatures of $<110^{\circ} \mathrm{C}$ following deposition. Estimated maximum paleotemperatures between $\sim 70^{\circ}$ and $90^{\circ} \mathrm{C}$ are also suggested by $\mathrm{R}_{\mathrm{o}}$ values between $\sim 0.31$ and 0.49 percent from the Colville Group and Sagavanirktok Formation near the surface in numerous wells near the Colville River (Bayliss and Magoon, 1988).

Because none of the samples have been totally annealed following deposition, it is not possible to obtain a direct estimate of the time at which the samples began to cool from maximum paleotemperatures. However, the form of the fission-track length distributions suggests that cooling from maximum paleotemperatures was rapid because only long tracks were preserved and each distribution has a small standard deviation. Applying the track annealing model of Laslett and others (1987) to the fission-track data from the upper group, and accounting for the presence of young grains in the samples and the regional vitrinite-reflectance data, suggests that rapid cooling from maximum paleotemperatures to $<40^{\circ} \mathrm{C}$ occurred over $\sim 3$ to 5 m.y. at some time between $\sim 70$ and 50 Ma. The youngest precise individual-grain ages present in the upper group rocks are $\sim 60 \mathrm{Ma}$; this suggests that the cooling episode occurred sometime during the Paleocene.

\section{LOWER GROUP}

Inspection of the single-grain age data from the lower group samples $(\mathrm{n}=8)$ shows that the fission-track ages are much younger than their stratigraphic ages indicating age reduction following deposition. Because all grains from each mount represent a single population, this suggests that all grains dated were reset after deposition and subsequently cooled from paleotemperatures $>110^{\circ} \mathrm{C}$. $\mathrm{R}_{\mathrm{o}}$ values of $\sim 0.70$ to 0.75 percent from Nanushuk Group rocks exposed in the northern foothills (Johnsson and others, 1992) suggest exposure to maximum paleotemperatures of $\sim 110^{\circ}$ to $130^{\circ} \mathrm{C}$, and the weighted mean age for these samples of $\sim 56 \pm 4 \mathrm{Ma}( \pm 2 \sigma)$ indicates the time at which these samples cooled from maximum paleotemperatures. Onset of cooling during the Paleocene is consistent with the young individual-grain ages present in the upper group samples. Many lower group rocks also contain some precise individual-grain ages $<\sim 30 \mathrm{Ma}$ suggesting some grains could be recording a period of cooling at that time. This is most evident in sample 5 in which 
3 out of 25 individual grains dated have ages of $\sim 20$ to $25 \mathrm{Ma}$ (fig. 8).

Modeling of the fission-track data from the lower group suggests that rapid cooling from paleotemperatures of $>110^{\circ}$ to $\sim 50^{\circ} \mathrm{C}$ occurred during the Paleocene at $\sim 56 \pm 4$ Ma. Furthermore, the data are best explained if the sample experienced a second discrete episode of cooling over $\sim 5$ m.y. during the Oligocene to Miocene (between $\sim 30$ and $15 \mathrm{Ma}$ ) from

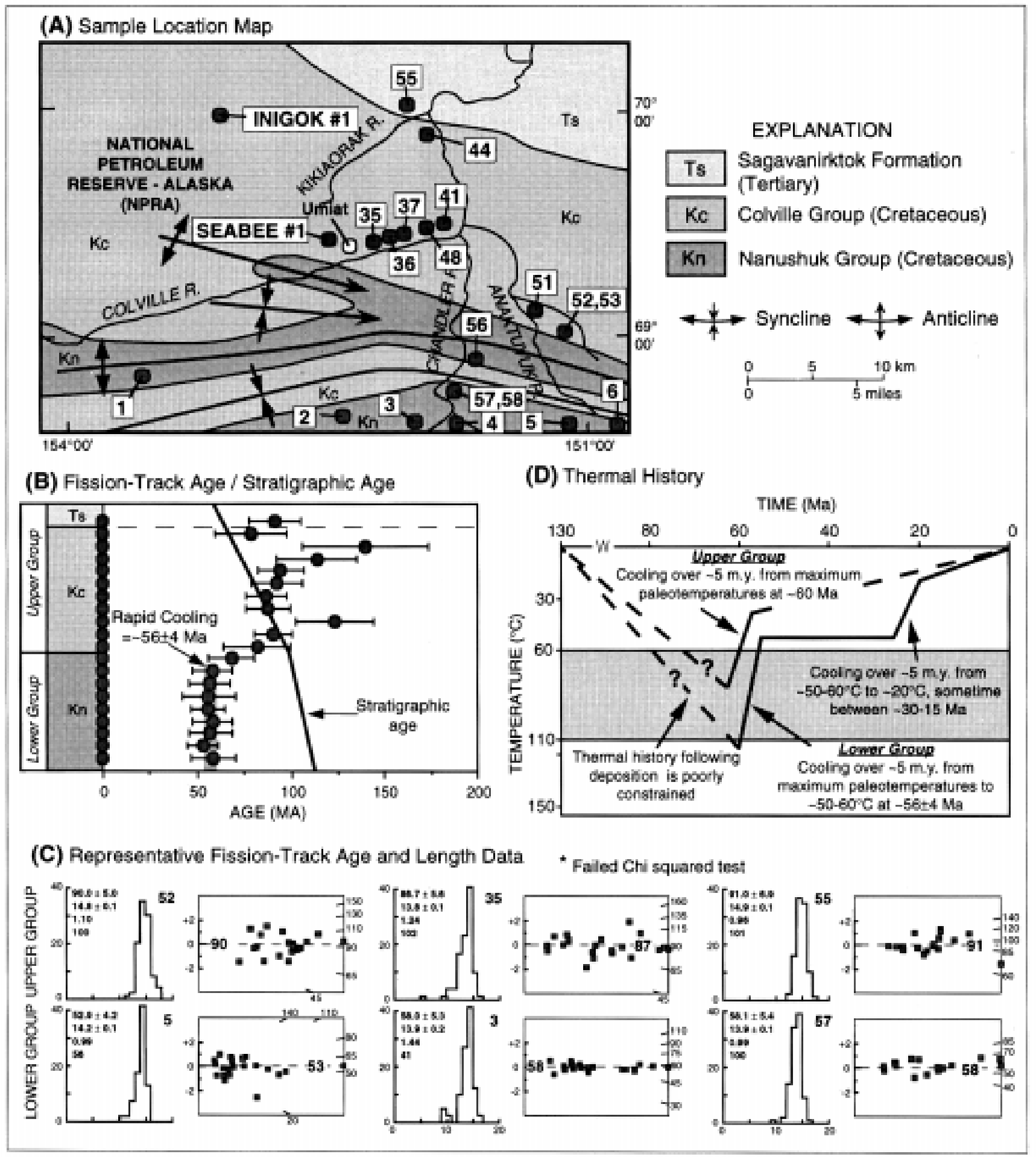

Figure 8. Composite figure showing (A) sample location map (numbers in boxes are sample numbers, map modified after Mull and Adams, 1989), (B) relation between fission-track age, stratigraphy, and stratigraphic age (error bars are $\pm 2 \sigma$ ), (C) representative fission-track data, and (D) generalized best-fit time-temperature history for northern foothills and Colville River data set. Representative fission-track data explained in caption of figure 4. 
paleotemperatures in the range of $\sim 40^{\circ}$ to $50^{\circ} \mathrm{C}$ to $\sim 10^{\circ}$ to $20^{\circ} \mathrm{C}$ (fig. 8).

\section{HUSKY SEABEE TEST WELL NO. 1}

Apatite-fission-track ages range between 102.3 \pm 17.6 $\mathrm{Ma}$, at an estimated present-day temperature of $\sim 19^{\circ} \mathrm{C}$ at 915 $\mathrm{m}$ depth, to $6.7 \pm 4.4 \mathrm{Ma}$, at an estimated present-day temperature of $\sim 102^{\circ} \mathrm{C}$ at $3,665 \mathrm{~m}$ depth. Estimates of presentday temperature are determined using a geothermal gradient of $\sim 30.0^{\circ} \mathrm{C} / \mathrm{km}$ calculated using a corrected bottom hole temperature (BHT) of $\sim 134^{\circ} \mathrm{C}$ at $4,759 \mathrm{~m}$ depth reported by Magoon and others (1988) and a mean surface temperature of $\sim-8.9^{\circ} \mathrm{C}$ reported by Lachenbruch and others (1988). Apatite-fission-track parameters plotted against sample depth and present temperature for samples from the Seabee No. 1 well are shown in figure 9.

\section{INTERPRETATION OF FISSION-TRACK AND VITRINITE-REFLECTANCE DATA}

Apatite-fission-track and vitrinite-reflectance data suggest that samples from the Seabee No. 1 well have experienced elevated paleotemperatures after deposition. As illustrated in figure 9, the mean or pooled fission-track ages (between $\sim 7$ and $50 \mathrm{Ma}$ ) for the deepest six samples are all significantly less than the stratigraphic ages (between $~ 90$ and $208 \mathrm{Ma}$ ), and the majority of individual-grain ages from throughout the well are significantly less than the stratigraphic age. Additionally, the measured mean fission-track lengths are much shorter than would be expected if they had formed at the prevailing temperatures. In principle, lower than expected mean fission-track lengths could reflect inheritance of shorter fission tracks from source terrane rocks, or alternatively, the samples may have been subjected to higher postdeposition paleotemperatures sufficient to produce the observed reduction in mean fission-track length. Because the fission-track ages from the deepest samples are less than the respective stratigraphic ages, the discrepancy cannot be explained in terms of inherited short tracks from source terranes and must therefore be due to the effects of enhanced fission-track annealing at elevated paleotemperatures after deposition. Finally, vitrinite-reflectance data from Magoon and others (1988) of between $\sim 0.43$ percent, at $215 \mathrm{~m}$ depth, to $\sim 2.65$ percent, at $4,759 \mathrm{~m}$ depth, confirm that all samples experienced elevated paleotemperatures following deposition and that the deepest five samples were exposed to paleotemperatures $>110^{\circ} \mathrm{C}$. These vitrinite-reflectance data suggest that the stratigraphic section experienced maximum paleotemperatures of between $\sim 70^{\circ} \mathrm{C}$, at $215 \mathrm{~m}$ depth, to $\sim 220^{\circ} \mathrm{C}$, at $4,759 \mathrm{~m}$ depth, values which are much higher than present-day estimates of $-2^{\circ} \mathrm{C}$ and $134^{\circ} \mathrm{C}$, respectively.
Applying the track annealing model of Laslett and others (1987) to the fission-track data from the shallowest two samples suggests that the reduced individual fission-track grain ages resulted from annealing at temperatures between $\sim 80^{\circ}$ and $110^{\circ} \mathrm{C}$ prior to rapid cooling. The best match for the available data suggests cooling on the order of $\sim 30^{\circ}$ to $40^{\circ} \mathrm{C}$ occurred over $\sim 5$ to $10 \mathrm{~m}$.y. between $\sim 65$ and $55 \mathrm{Ma}$. Furthermore, the presence in sample 12 of many individual grains with ages between $\sim 15$ and 25 Ma suggests an episode of cooling occurred sometime during or since $\sim 25$ to $15 \mathrm{Ma}$.

Data from the deepest five samples collected from the well suggest that they experienced paleotemperatures $>110^{\circ} \mathrm{C}$ after deposition and were subsequently cooled to present temperatures (appendix A). Modeling the fissiontrack data from sample 11 suggests the sample initially cooled $\sim 30^{\circ}$ to $40^{\circ} \mathrm{C}$ over $\sim 5$ to $10 \mathrm{~m}$.y. from maximum paleotemperatures to between $\sim 80^{\circ}$ and $90^{\circ} \mathrm{C}$, at some time between $\sim 65$ and $55 \mathrm{Ma}$. At this time samples deeper in the section remained at temperatures $>110^{\circ} \mathrm{C}$. A second cooling episode occurred at some time between $\sim 25$ and $15 \mathrm{Ma}$, when the entire stratigraphic section cooled $\sim 20^{\circ}$ to $30^{\circ} \mathrm{C}$ to paleotemperatures $<110^{\circ} \mathrm{C}$. Cooling between $\sim 65$ and $55 \mathrm{Ma}$ and between $\sim 25$ and $15 \mathrm{Ma}$ is compatible with evidence of cooling determined from outcrop samples along the northern foothills and the Colville River regions discussed previously.

\section{CALCULATION OF MAXIMUM PALEOGEOTHERMAL GRADIENT AND AMOUNT OF UPLIFT AND EROSION}

As explained earlier, the slope of the fitted linear relationship between maximum paleotemperature and present depth provides a direct estimate of the maximum paleogeothermal gradient (maximum paleotemperature profile) prior to cooling. Figure 10 shows that the best-fit estimate (least squares regression) of the maximum paleogeothermal gradient (derived using the maximum paleotemperature profile) is equivalent to the estimated present-day geothermal gradient of $\sim 30^{\circ} \mathrm{C} / \mathrm{km}$. This suggests that basin heat flow has not changed since maximum paleotemperatures were reached, however, a great deal of section must have been removed as a result of uplift and erosion because the maximum geothermal gradient is offset towards higher temperatures as a result of previous exposure to elevated temperatures.

Because any change in the geothermal gradient since the time of maximum paleotemperatures has been negligible, the amount of removed section can be estimated by dividing the amount of cooling by the geothermal gradient. For the Seabee No. 1 well, the estimated maximum paleotemperature at the surface is $\sim 65^{\circ}$ to $70^{\circ} \mathrm{C}$, the mean annual surface temperature (subareal) in the Maastrichtian just prior to the time of cooling was $\sim 5^{\circ} \mathrm{C}$ (Spicer, 1987), and the present mean 
annual surface temperature is $\sim-9^{\circ} \mathrm{C}$ (Lachenbruch and others, 1988). Using a geothermal gradient of $\sim 30^{\circ} \mathrm{C} / \mathrm{km}$, the Seabee No. 1 well has experienced $\sim 2.1 \mathrm{~km}$ of uplift and erosion and $\sim 0.5 \mathrm{~km}$ of apparent uplift and erosion resulting from a decrease in mean annual surface temperature to cool the section to present temperature conditions.

\section{BURIAL HISTORY}

Figure 11 shows the proposed burial history for the Seabee No. 1 well, as constrained by the regional stratigraphy, apatite-fission-track, and vitrinite-reflectance data. The Seabee No. 1 well section experienced maximum paleotemperatures during the early Paleocene at which time sedimentary rocks of the Colville Group, Nanushuk Group, and the upper part of the Torok Formation remained at paleotemperatures $£ 110^{\circ} \mathrm{C}$, while the lower part of the Torok Formation and deeper rock units were exposed to paleotemperatures $>110^{\circ} \mathrm{C}$. In the Paleocene to early Eocene at some time between $\sim 65$ and $55 \mathrm{Ma}$, the entire section experienced cooling of $\sim 30^{\circ}$ to $40^{\circ} \mathrm{C}$ in $\sim 5$ Ma due to $\sim 1$ to 1.3 $\mathrm{km}$ of uplift and erosion. This cooling caused the lower part of the Torok Formation and upper part of the Fortress Mountain Formation to cool below paleotemperatures of $\sim 110^{\circ} \mathrm{C}$. Finally, during the late Oligocene to middle Miocene, between $\sim 25$ and $15 \mathrm{Ma}$, the stratigraphic section experienced cooling of $\sim 20^{\circ}$ to $30^{\circ} \mathrm{C}$ over $\sim 10$ m.y. ( $\sim 0.5 \mathrm{~km}$ of uplift and erosion and $\sim 0.5 \mathrm{~km}$ of apparent uplift and erosion resulting from a decrease in mean annual surface temperature). This cooling episode brought the base of the Torok Formation to paleotemperatures of $\sim 60^{\circ} \mathrm{C}$ and the base of the sampled section to paleotemperatures between $\sim 60^{\circ}$ to $110^{\circ} \mathrm{C}$. Minor cooling since this cooling episode has brought the rocks to presentday temperature conditions.

\section{HUSKY INIGOK TEST WELL NO. 1}

Apatite-fission-track ages range from 97.6 $\pm 19.0 \mathrm{Ma}$, at an estimated present temperature of $\sim 17^{\circ} \mathrm{C}(802 \mathrm{~m}$ depth $)$, to $11.7 \pm 9.0 \mathrm{Ma}$, at an estimated present-day temperature of $\sim 121^{\circ} \mathrm{C}(3,811 \mathrm{~m} \mathrm{depth})$, and $0 \mathrm{Ma}$ at an estimated presentday temperature of $\sim 193^{\circ} \mathrm{C}(5,905 \mathrm{~m}$ depth $)$. These estimates

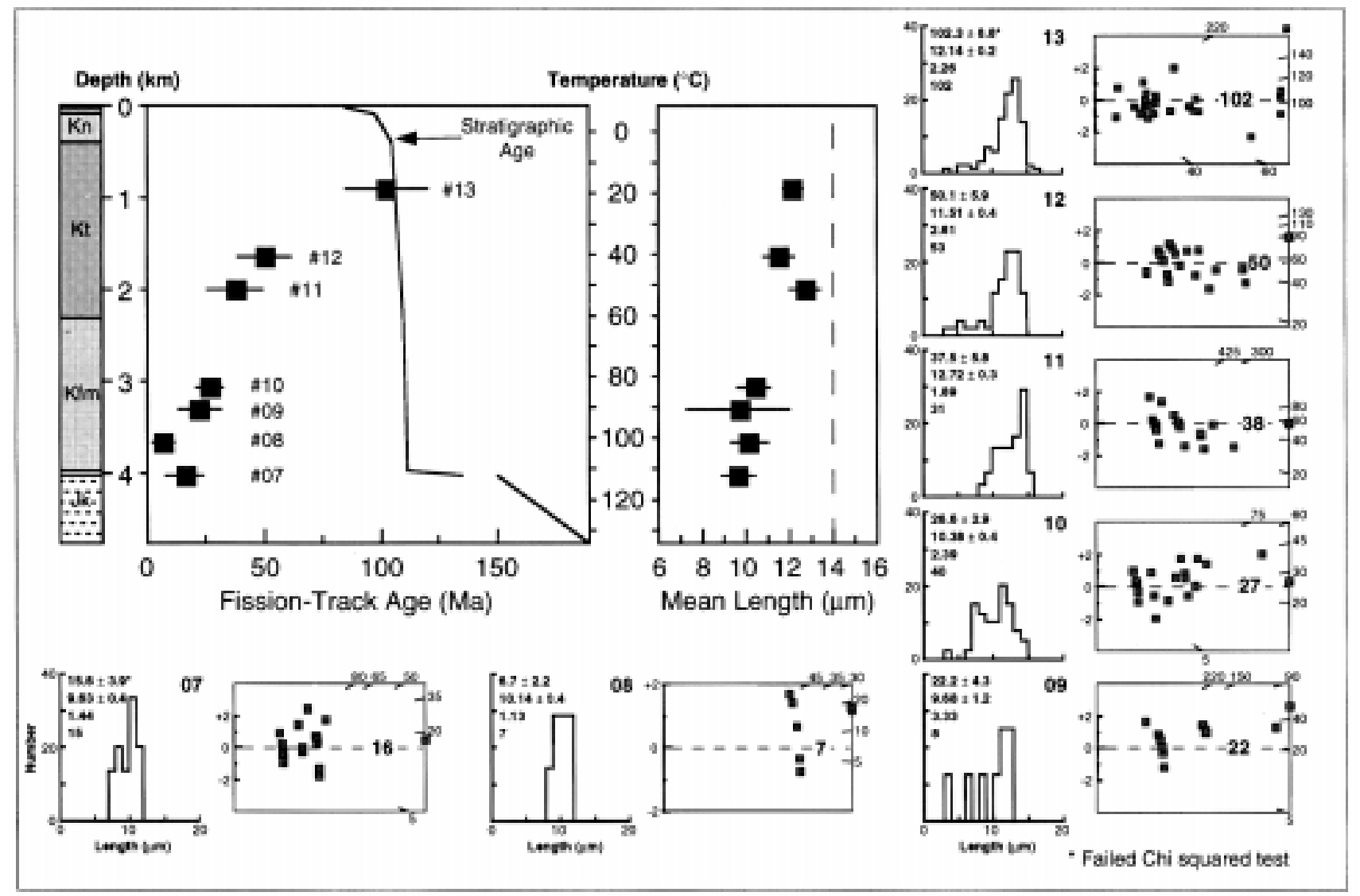

Figure 9. Composite figure showing fission-track parameters plotted against sample depth and present-day temperature for samples from Husky Seabee No. 1 well and representative fissiontrack data for this well. Variation of stratigraphic age with depth is shown as solid line in central panel. Error bars are $\pm 2 \sigma$. Symbols: Kn, Cretaceous Nanushuk Group; Kt, Cretaceous Torok Formation; Kfm, Cretaceous Fortress Mountain Formation; Jk, Jurassic Kingak Shale. Representative fission-track data explained in caption of figure 4 . 
of present-day temperature are determined using a geothermal gradient of $\sim 34.5^{\circ} \mathrm{C} / \mathrm{km}$ calculated using a BHT of $\sim 201^{\circ} \mathrm{C}$ at $6,129 \mathrm{~m}$ depth, reported by Magoon and others (1988), and a mean surface temperature of $\sim-10.5^{\circ} \mathrm{C}$, as reported by Lachenbruch and others (1988). The occurrence within the well of fission tracks in apatite grains at presentday temperatures $>110^{\circ} \mathrm{C}$, however, is unusual and suggests that either (1) the preserved section in the well has experienced recent rapid burial to higher temperatures, (2) there was a problem with contamination, (3) that these apatite grains have an abnormally high $\mathrm{Cl}$ content, (4) the geothermal gradient has increased recently $(<\sim 1 \mathrm{Ma})$, or (5) the present-day temperature estimates are incorrect. The first three factors could be eliminated owing to lack of evidence for recent rapid burial (Magoon and others, 1988), abnormally $\mathrm{Cl}$ values (O'Sullivan, unpub. data), or contamination. Therefore, in this

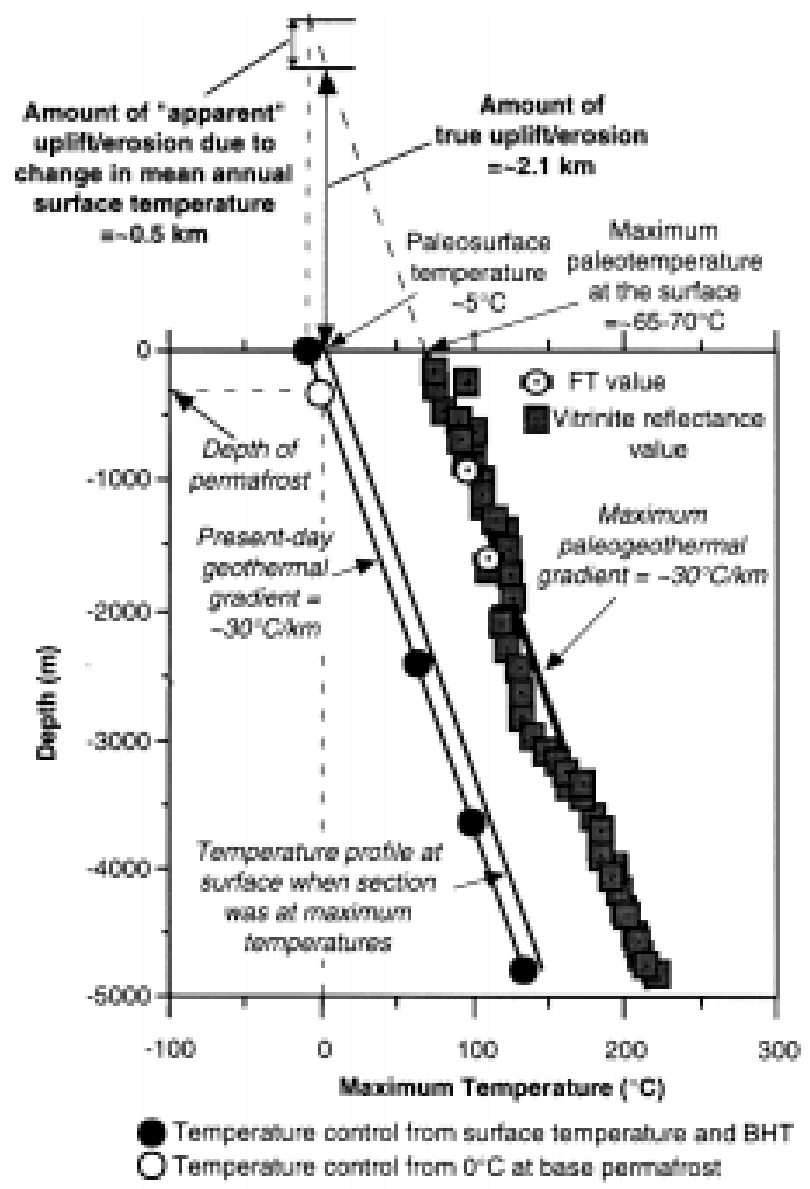

Figure 10. Estimated maximum paleotemperature profile in the Husky Seabee No. 1 well, derived from available fission-track and vitrinite-reflectance values, plotted against sample depth. Also shown is maximum temperature profile expected if total amount of uplift and erosion was due to a change in mean annual surface temperature. Original vitrinite-reflectance values from Magoon and others (1988). Values used to calculate present-day gradient are given in appendix A. Symbols: FT, fission track; BHT, bottom-hole temperature. See text for details. case it is most likely that the present-day temperature estimates are incorrect or that the geothermal gradient has increased very recently and has not yet affected the fissiontrack parameters.

On the basis that all fission tracks should be annealed at present temperatures $\geq 110^{\circ} \mathrm{C}$, a geothermal gradient of $\sim 28^{\circ} \mathrm{C} / \mathrm{km}$, rather than the value of $\sim 35^{\circ} \mathrm{C} / \mathrm{km}$ determined from the BHT, has been used in modeling the fission-track data (see appendix A). Down-hole temperature estimates in the remaining discussion are based on the lower geothermal gradient. The apatite-fission-track parameters plotted against sample depth and present-day temperature for samples from the Inigok No. 1 well (based on the lower geothermal gradient) are shown in figure 12 .

\section{INTERPRETATION OF FISSION-TRACK AND VITRINITE-REFLECTANCE DATA}

Apatite-fission-track and vitrinite-reflectance data suggest that samples from the Inigok No. 1 well have experienced elevated paleotemperatures after deposition. Evidence for this includes (1) many pooled fission-track ages and the

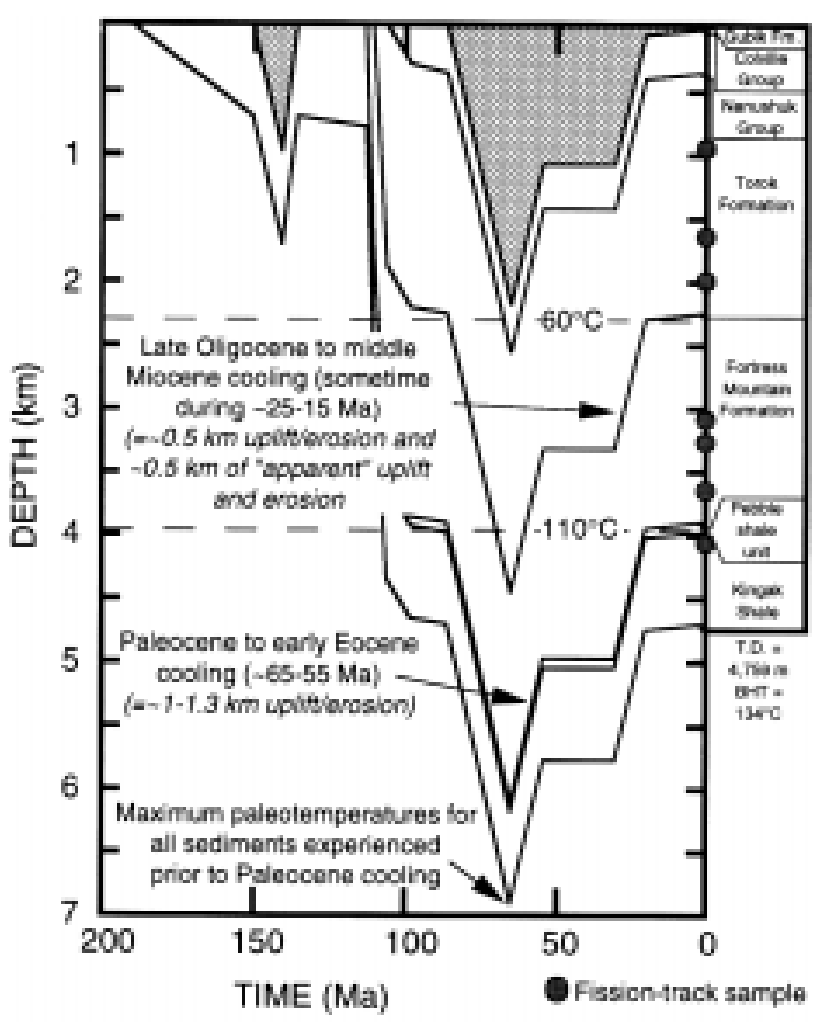

Figure 11. Proposed depositional history for Husky Seabee No. 1 well based on fission-track, vitrinite-reflectance, and stratigraphic parameters. Results suggest that maximum paleotemperatures were reached in the early Paleocene prior to two episodes of rapid cooling in the Tertiary. Symbols: BHT, bottom-hole temperature; T.D., total depth to bottom of well. See text for details. 
majority of individual-grain ages are significantly less than stratigraphic ages (fig. 12), (2) the measured mean fissiontrack lengths are much shorter than would be expected if they had formed at the present-day temperatures, and (3) vitrinitereflectance data from the Inigok No. 1 well (Bayliss and Magoon, 1988; Magoon and others, 1988) indicate that the well experienced maximum paleotemperatures much higher than present-day temperature estimates.

Data from the shallowest three samples $(125,126$, and 127) are characteristic of samples which have not experienced paleotemperatures $>110^{\circ} \mathrm{C}$ after deposition; all individual-grain ages that are significantly less than stratigraphic ages can be explained by annealing at temperatures between $\sim 75^{\circ}$ and $90^{\circ} \mathrm{C}$. Applying the track annealing model of Laslett and others (1987) to the fissiontrack data from samples 125 and 126 suggests that maximum paleotemperatures between $\sim 75^{\circ}$ and $90^{\circ} \mathrm{C}$ were reached during the early Paleocene, prior to cooling at some time between $\sim 60$ and $45 \mathrm{Ma}$. The best model to fit the available data suggests cooling on the order of $\sim 30^{\circ}$ to $40^{\circ} \mathrm{C}$ occurred in $\sim 5 \mathrm{~m}$.y. at some time in the Paleocene to early Eocene between $\sim 65$ and $55 \mathrm{Ma}$.
Data from the six deepest samples from the well are characteristic of samples that have experienced maximum paleotemperatures $>110^{\circ} \mathrm{C}$ after deposition and have subsequently cooled. Modeling of the data from samples 122, 123, and 124 suggest they experienced a two-phase cooling history. They initially cooled $\sim 30^{\circ}$ to $40^{\circ} \mathrm{C}$ from maximum paleotemperatures to $\sim 80^{\circ}$ to $90^{\circ} \mathrm{C}$ during the Paleocene to early Eocene at some time between $\sim 65$ and 55 Ma. Furthermore, the data are best explained by cooling on the order of $\sim 15^{\circ}$ to $20^{\circ} \mathrm{C}$ during a second episode in the middle Oligocene to middle Miocene at some time between $\sim 30$ and $15 \mathrm{Ma}$.

\section{CALCULATION OF MAXIMUM PALEOGEOTHERMAL GRADIENT AND AMOUNT OF UPLIFT AND EROSION}

As shown in figure 13, the slope of maximum paleotemperatures (maximum paleogeothermal gradient) is nonlinear. Explaining this nonlinearity is beyond the scope of the present study, however, the best-fit estimate (least squares regression) of the maximum paleogeothermal gradi-

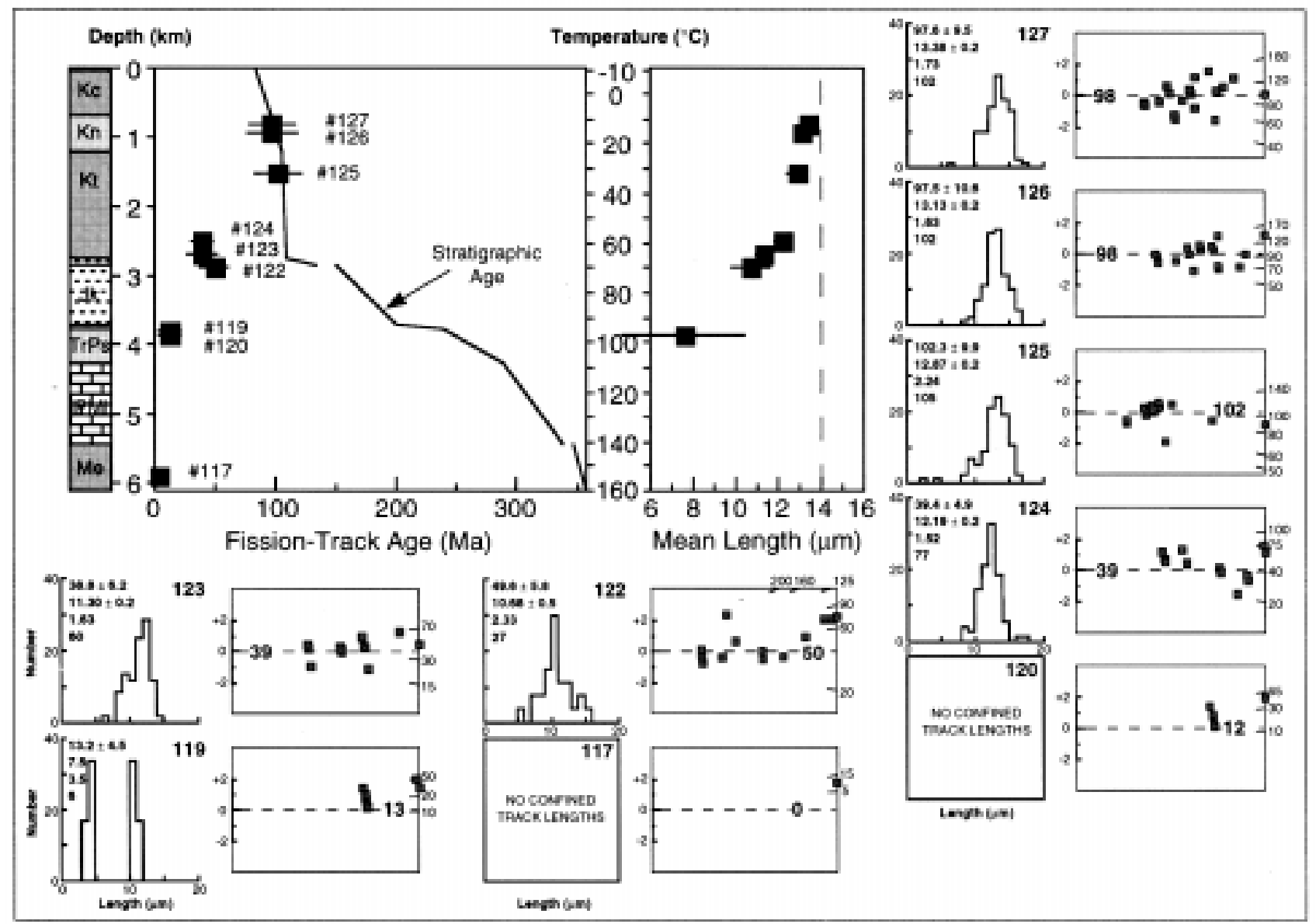

Figure 12. Composite figure showing fission-track parameters plotted against sample depth and present-day temperature for samples from Husky Inigok No. 1 well and representative fission-track data for this well. Variation of stratigraphic age with depth is shown as solid line in central panel. Error bars are $\pm 2 \sigma$. Samples 117 and 120 did not contain any confined tracks.
Symbols: Kc, Cretaceous Colville Group; Kn, Cretaceous Nanushuk Group; Kt, Cretaceous Torok Formation; Jk, Jurassic Kingak Shale; TrPs, Permian and Triassic Sadlerochit Group; IPMl, Mississippian and Pennsylvanian Lisburne Group; Me, Mississippian Endicott Group. Representative fissiontrack data explained in caption of figure 4 . 
ent for the upper half of the well suggests that the maximum paleogeothermal gradient (based on the vitrinite-reflectance data) is equivalent to the estimated present-day geothermal gradient of $\sim 28^{\circ} \mathrm{C} / \mathrm{km}$ (based on the fission-track data). This indicates that basin heat flow has not changed, at least not in the upper half of the preserved section in the well, since maximum paleotemperatures were reached and the maximum paleotemperature profile is offset slightly towards higher temperatures as a result of previous exposure to elevated temperatures. Because of the similarity between the geothermal gradients calculated separately using the vitrinite-reflectance and fission-track data, I propose that the strata were exposed to a gradient of $\sim 28^{\circ} \mathrm{C} / \mathrm{km}$ at the time both the vitrinite-reflectance and fission-track parameters were set. Any higher estimated geothermal gradient for the Inigok No. 1 well, such as the value of $\sim 38^{\circ} \mathrm{C} / \mathrm{km}$ proposed by Deming (oral commun.,

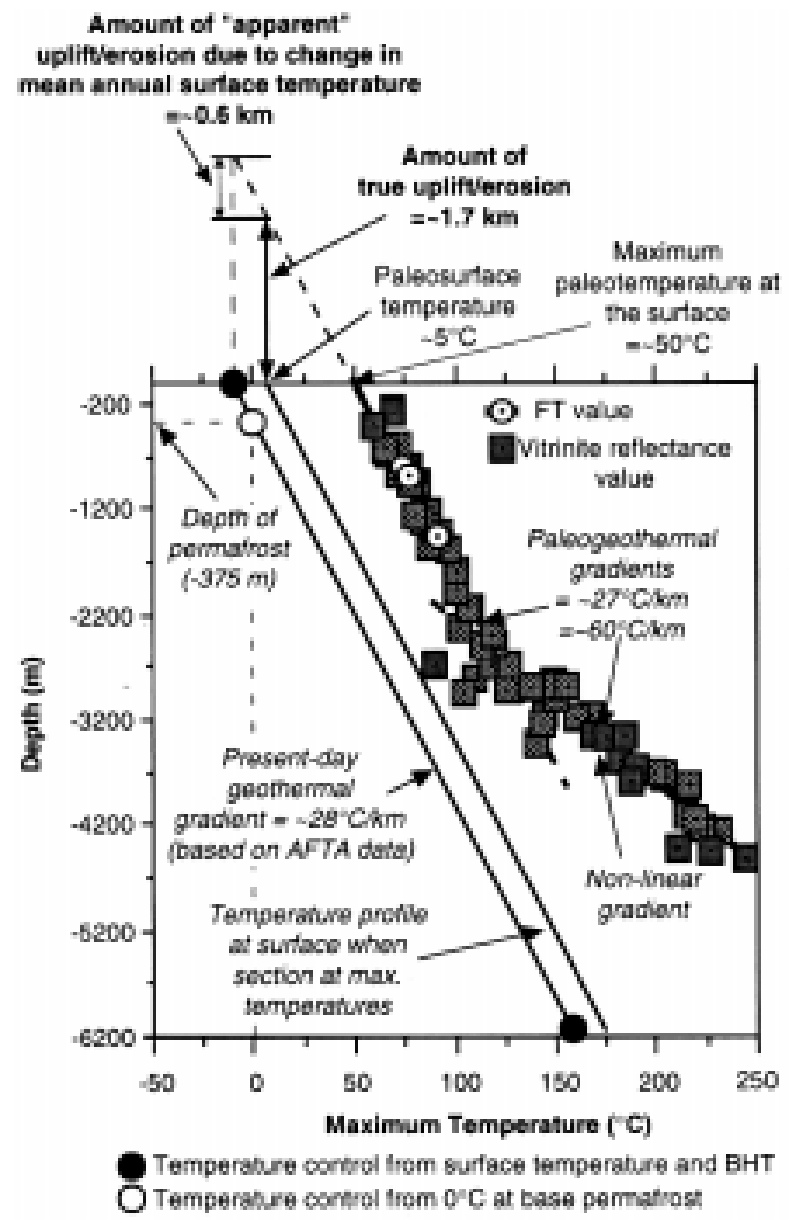

Figure 13. Estimated maximum paleotemperature profile in Husky Inigok No. 1 well, derived from available fission-track and vitrinitereflectance values, plotted against sample depth. Also shown is maximum temperature profile expected if total amount of uplift and erosion was due to a change in mean annual surface temperature. Original vitrinite-reflectance values from Magoon and others (1988). Values used to calculate present-day gradient are given in appendix A. Symbols: FT, fission track; BHT, bottom-hole temperature. See text for details.
1993), must be the result of a recent increase in the geothermal gradient that has not yet effected either the fission-track or vitrinite-reflectance data. Therefore, for the Inigok No. 1 well, the estimated maximum paleotemperature at the surface is $\sim 50^{\circ} \mathrm{C}$, the mean annual surface temperature in the Maastrichtian just prior to the time of cooling was $\sim 5^{\circ} \mathrm{C}$ (Spicer, 1987), and the present-day mean annual surface temperature is $\sim-11^{\circ} \mathrm{C}$ (Lachenbruch and others, 1988). Assuming a geothermal gradient of $\sim 28^{\circ} \mathrm{C} / \mathrm{km}$, the well has experienced $\sim 1.7 \mathrm{~km}$ of uplift and erosion and $\sim 0.6 \mathrm{~km}$ of apparent uplift and erosion resulting from a decrease in mean annual surface temperature to cool the section to present temperature conditions (fig. 13).

\section{BURIAL HISTORY}

Figure 14 shows the proposed burial history for the Inigok No. 1 well as constrained by the regional-stratigraphy, apatite-fission-track, and vitrinite-reflectance data. Rocks in the subsurface experienced maximum paleotemperatures during the early Paleocene at which time sedimentary rocks of the Colville Group, Nanushuk Group, and the upper part of the Torok Formation remained at paleotemperatures $\leq 110^{\circ} \mathrm{C}$, while the lower part of the Torok Formation and deeper rock units were exposed to paleotemperatures $>110^{\circ} \mathrm{C}$. Between $\sim 65$ and $55 \mathrm{Ma}$, the entire section experienced cooling of $\sim 30^{\circ}$ to $40^{\circ} \mathrm{C}$ over $\sim 5 \mathrm{~m}$.y. due to $\sim 1$ to $1.3 \mathrm{~km}$ of uplift and erosion. Finally, during the middle Oligocene to early Miocene (between $\sim 25$ and $15 \mathrm{Ma}$ ) the section experienced cooling of $\sim 15^{\circ}$ to $20^{\circ} \mathrm{C}$ over $\sim 5$ to 10 m.y. ( $\sim 0.6 \mathrm{~km}$ of apparent uplift and erosion resulting from a decrease in mean annual surface temperature). It is also possible that the well section experienced some true uplift and erosion during this later cooling episode, however, the amount of any such uplift and erosion is difficult to constrain this with the present data set. Minor cooling since then has brought the rocks to present conditions.

\section{EXXON ALASKA STATE C-1 WELL}

Apatite-fission-track parameters plotted against sample depth and present-day temperature for samples from the Alaska State C-1 well are shown in figure 15. Apatite-fission-track ages decrease from $81.0 \pm 24.1 \mathrm{Ma}$, at an estimated present-day temperature of $\sim 7^{\circ} \mathrm{C}$ at $\sim 671 \mathrm{~m}$ depth, to 11.2 $\pm 10.4 \mathrm{Ma}$, at an estimated present temperature of $\sim 99^{\circ} \mathrm{C}$ at $\sim 4,146 \mathrm{~m}$ depth.

\section{INTERPRETATION OF FISSION-TRACK AND VITRINITE- REFLECTANCE DATA}

The apatite-fission-track and vitrinite-reflectance data from the Alaska State C-1 well suggest that rocks in the sub- 
surface are presently experiencing temperatures close too maximum values. Even though the fission-track ages for the two deepest samples are significantly less than the stratigraphic age, they show a degree of annealing possible at the present-day temperatures of these samples (between $\sim 95^{\circ}$ and $100^{\circ} \mathrm{C}$ ). Individual-grain ages throughout the section are significantly greater than the stratigraphic age, a fact which suggests that little annealing has occurred since deposition; an exception is the presence of a cluster of $~ 20$-Ma grains in each of the two samples from the Canning Formation (samples 16 and 17). Finally, vitrinite-reflectance data from the Alaska State C-1 well range between $\sim 0.24$ percent at $1,267 \mathrm{~m}(4,155$ $\mathrm{ft}$ ) depth to $\sim 0.53$ percent at $4,085 \mathrm{~m}(13,400 \mathrm{ft})$ depth. These data indicate maximum paleotemperatures experienced by the well of between $\sim 19^{\circ} \mathrm{C}$, at $1,267 \mathrm{~m}$ depth to $\sim 95^{\circ} \mathrm{C}$, at 4,085 $\mathrm{m}$ depth, are equivalent to present-day estimates of $\sim 22^{\circ}$ and $\sim 95^{\circ} \mathrm{C}$, respectively.

From the apatite-fission-track data alone it is not possible to determine the postdepositional time-temperature history of these rocks with any precision. Because none of the apatite-fission-track ages of the samples have been totally reset, it is unclear whether the shortened fission tracks in each sample were affected prior to or after deposition. The strong resemblance of individual-grain ages and fission-track length

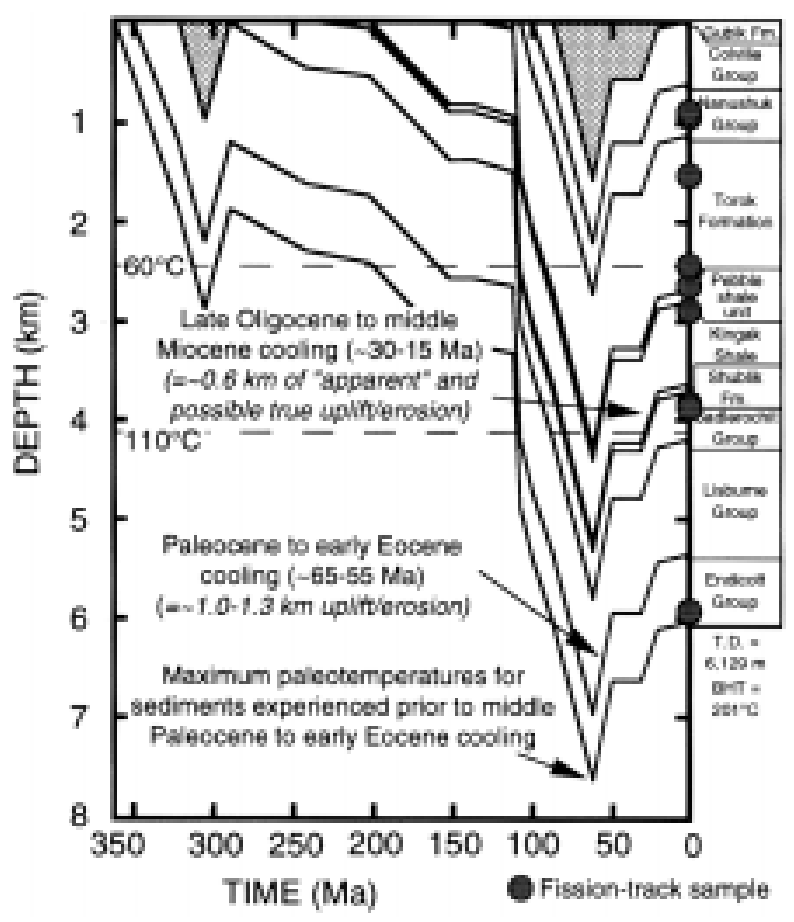

Figure 14. Proposed depositional history for Husky Inigok No. 1 well based on fission-track, vitrinite-reflectance, and stratigraphic parameters. Results suggest that maximum paleotemperatures were reached in the early Paleocene prior to two episodes of rapid cooling in the Tertiary. Symbols: BHT, bottom-hole temperature; T.D., total depth to bottom of well. See text for details. distributions between the most shallow two samples which are at very different present-day temperatures $\left(\sim 7^{\circ}\right.$ and $\sim 63^{\circ} \mathrm{C}$, respectively), suggests that the discrepancy between observed values of mean fission-track length to present-day temperatures should be explained in terms of previously shortened inherited fission tracks.

Applying the track annealing model of Laslett and others (1987) to the fission-track data from samples 16 and 17 suggests that they have not experienced paleotemperatures much higher than present-day temperature values. To explain the presence of many individual grains with ages of $\sim 20 \mathrm{Ma}$ (fig. 15), these samples must have previously experienced an episode of cooling from elevated paleotemperatures followed by heating (by continued burial?) to the present-day temperatures. Modeling the distributions of fission-track lengths in the remaining samples support suggestions that the section experienced an episode of cooling on the order of $\sim 15^{\circ}$ to $20^{\circ} \mathrm{C}$ during the late Tertiary.

\section{CALCULATION OF MAXIMUM PALEOGEOTHERMAL GRADIENT AND AMOUNT OF UPLIFT AND EROSION}

As shown in figure 16, the best-fit estimate (least squares regression) of the maximum paleogeothermal gradient, derived using the maximum paleotemperature profile, suggests that the maximum paleogeothermal gradient is equivalent to the present-day geothermal gradient of $\sim 27^{\circ} \mathrm{C} /$ $\mathrm{km}$. The overlapping plots suggest that samples in the Alaska State C-1 well are presently at maximum temperatures. However, in the case of this well, some amount of apparent uplift and erosion must have occurred in response to the decrease in the mean annual surface temperature from $\sim 5^{\circ}$ to $\sim-11^{\circ} \mathrm{C}$ during the early Tertiary. By plotting the expected maximum temperature profile present in the early Tertiary, I determined a value of $\sim 0.6 \mathrm{~km}$ for the apparent uplift and erosion resulting from a decrease in mean annual surface temperature.

\section{BURIAL HISTORY}

Figure 17 shows the proposed burial history for the Exxon Alaska State C-1 well. During the Late Cretaceous and early Tertiary, the well sequence was quickly buried owing to continuous deposition of the Canning Formation and Sagavanirktok Formation, with little or no uplift and erosion. Interpretation of the available apatite-fission-track data suggests that as a result of burial the Alaska State C-1 well section experienced close to maximum paleotemperatures during the late Oligocene followed by cooling on the order of $\sim 15^{\circ}$ to $20^{\circ} \mathrm{C}$ in the early to middle Miocene ( 20 to $10 \mathrm{Ma}$ ). I propose that this episode of cooling was due entirely to the regional decrease in mean annual surface temperature in the Miocene (from $\sim 5^{\circ}$ to $\sim-11^{\circ} \mathrm{C}$ ), a decrease which resulted in $\sim 0.6 \mathrm{~km}$ of apparent uplift and erosion resulting from a decrease in mean annual surface temperature (based on a geo- 
thermal gradient of $\sim 27^{\circ} \mathrm{C} / \mathrm{km}$ ). Subsequent burial during the Miocene and Pliocene has brought the Alaska State C-1 well section to present-day maximum temperatures.

\section{CAUSE OF ELEVATED PALEOTEMPERATURES}

The apatite-fission-track and vitrinite-reflectance data suggest that the Colville basin has experienced elevated paleotemperatures in the past prior to episodic cooling during the Tertiary. Explanations for the elevated paleotemperatures include (1) heating from elevated heat flow, perhaps due to regional plutonic activity or heating from circulating fluids along porous sedimentary layers, or (2) increased temperatures due to increased depth of burial and (or) thrust loading.

\section{HIGH TEMPERATURES DUE TO ELEVATED HEAT FLOW}

Relative to present geothermal gradients, there is little evidence for elevated heat flow on a regional scale throughout northern Alaska prior to Tertiary cooling. Data from the wells discussed in this paper suggest that the paleogeothermal gradients, which range between $\sim 27^{\circ}$ to $33^{\circ} \mathrm{C} / \mathrm{km}$, have remained relatively constant since the wells experienced maximum paleotemperatures in the Late Cretaceous and early Tertiary. Data from the Inigok No. 1 well, however, suggest that the well experienced a nonlinear maximum geothermal gradient sometime prior to Tertiary uplift and erosion. The cause of this nonlinear maximum geothermal gradient is unknown but seems to be localized.

Regional plutonic activity across the Colville basin is not known to have occurred during the Late Cretaceous or Tertiary. Only at $\sim 10,700 \mathrm{ft}(\sim 3,262 \mathrm{~m})$ depth in the East Teshekpuk No. 1 well was granitic basement penetrated. However, Bird and others (1978) report K/Ar radiometric ages for the granite of $\sim 332 \pm 10 \mathrm{Ma}$ (K-feldspar) and $243 \pm 7 \mathrm{Ma}$ (biotite), ages which indicate that it was emplaced long before the Tertiary cooling episodes recorded by the regional apatite-fission-track data. In addition, cooling of the Colville basin from maximum paleotemperatures seems to have been rapid (between $\sim 10^{\circ}$ and $17^{\circ} \mathrm{C} / \mathrm{m}$.y., as indicated by the apatite-fission-track data) and episodic, whereas any elevation of heat flow associated with intrusion would diminish at a

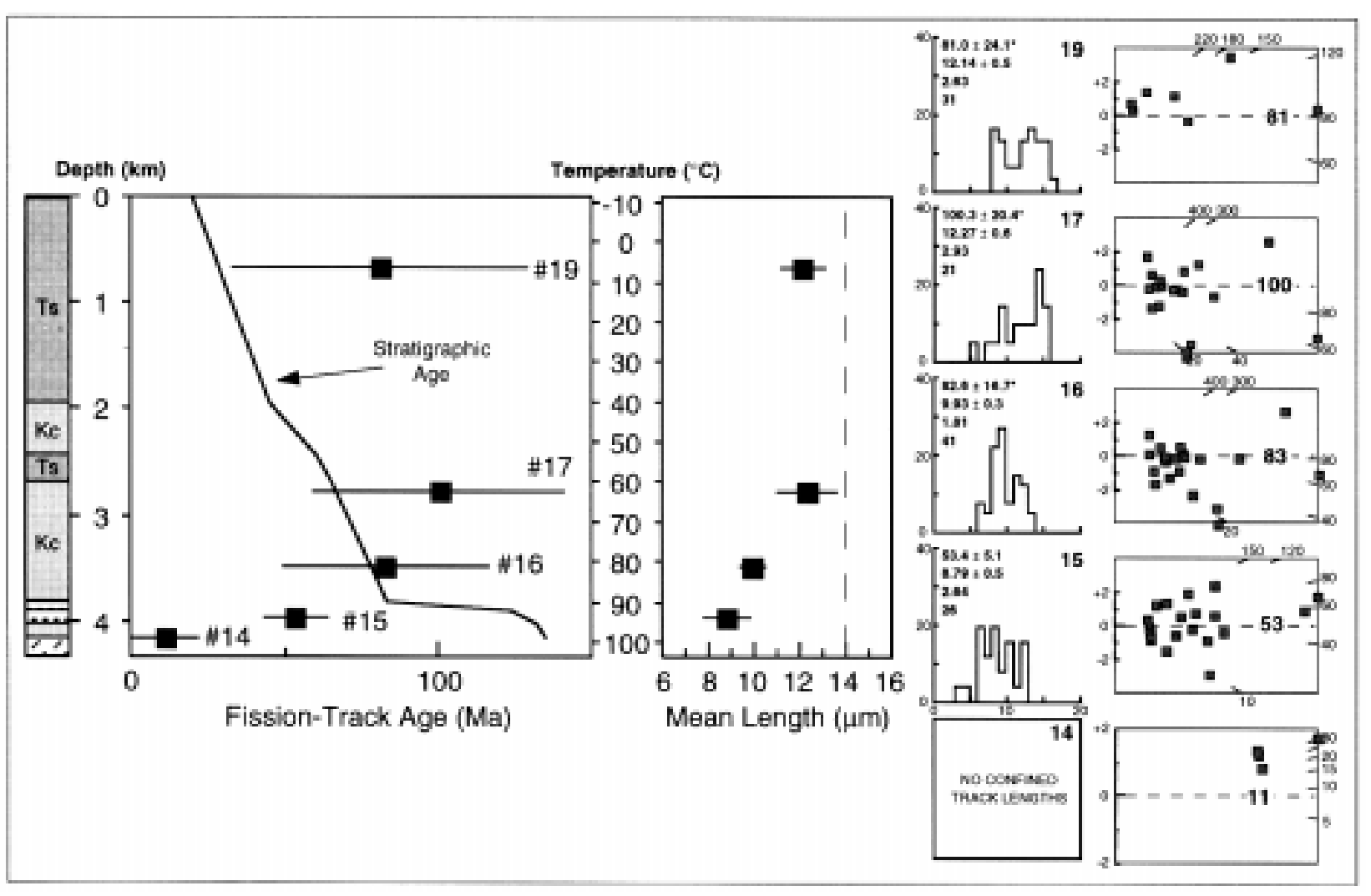

Figure 15. Composite figure showing fission-track parameters plotted against sample depth and present-day temperature for samples from Exxon Alaska State C-1 well and representative fission-track data for this well. Variation of stratigraphic age with depth is shown as solid line in central panel. Error bars are $\pm 2 \sigma$. Sample 14 did not contain any confined fission-tracks. Symbols: Ts, Tertiary Sagavanirktok Formation; Kc, Cretaceous Canning Formation. Representative fission-track data explained in caption of figure 4. 
slower rate of $<5.0^{\circ} \mathrm{C} / \mathrm{m}$.y. (Lee, 1979 ; Spera, 1980; Turner, 1981).

It is well known that ground water flow can transfer heat and modify subsurface temperatures (for example, Smith and Chapman, 1983), but until recently there has been no published analysis of the advective heat-transfer capacity of the present-day ground-water-flow system in the Colville basin. Using heat-flow measurements from the western North Slope region, Deming and others (1992, this volume) proposed that the region is presently dominantly influenced by forced convection generated by a topographically driven ground-water-flow system and that alternative explanations are unsatisfactory. Furthermore, they felt, on the basis of reported patterns in vitrinite-reflectance data (Bird, 1991a,b), that it is conceivable that the topographically driven groundwater-flow system existed at the same time that the vitrinitereflectance values were "frozen in" and has persisted since uplift began (Deming and others, 1992). Therefore, it is possible that heating from circulating fluids could be at least partially responsible for the elevated paleotemperatures experienced across the Colville basin prior to the recorded cooling events. However, heating from circulating fluids does not explain the episodic cooling events recorded by the fissiontrack data, and therefore, some other mechanism must be responsible.

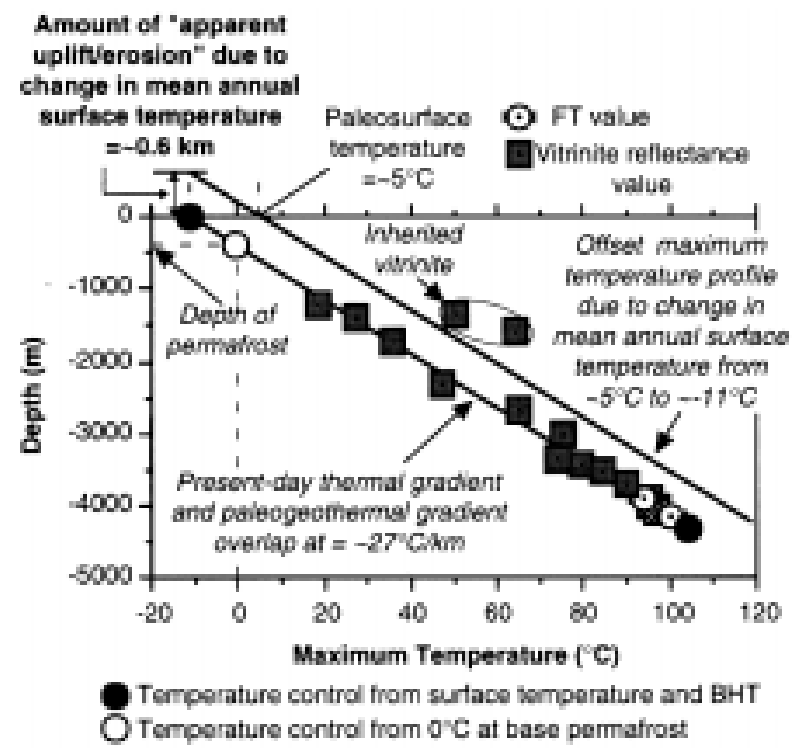

Figure 16. Estimated maximum paleotemperatures in the Exxon Alaska State C-1 well, derived from fission track and vitrinite reflectance plotted against sample depth. Present-day geothermal gradient is also shown for comparison with maximum paleogeothermal gradient. Present-day thermal gradient and maximum paleogeothermal gradient are equivalent; this suggests that this well is presently at maximum paleotemperatures. Paleogeothermal gradients were determined using a mean annual surface temperature of $\sim 5^{\circ} \mathrm{C}$ for the North Slope of Alaska in the Late Cretaceous (Spicer, 1987). Symbols: FT, fission track; BHT, bottom-hole temperature. See text for details.

\section{HIGH TEMPERATURES DUE TO BURIAL}

The obvious mechanism for the heating and rapid cooling indicated by the available fission-track data from throughout the Colville basin is subsidence and increased burial in response to sedimentation followed by uplift and erosion. If burial was responsible for the elevated paleotemperatures, many kilometers of overburden must have been removed from the presentday Brooks Range foothills during the Tertiary. Direct stratigraphic evidence that kilometer-scale overburden once existed is lacking. However, Bird (1987) reported evidence that Brookian deposits are more than $8 \mathrm{~km}$ thick along the foothills in the National Petroleum Reserve of Alaska (NPRA). Bird and Bader (1987) reported Brookian sequence sediments that are more than $7.6 \mathrm{~km}$ thick are present in the foredeep west of ANWR. Within ANWR, Bird and Magoon (1987; pl. 3) reported $\sim 6,700 \mathrm{~m}$ of Brookian sediments north of the Sabbath Creek area at the Hulahula Low on the basis of seismic interpretation by Bruns and others (1987). To the east, in the Mackenzie Delta region, Bird and Bader (1987) reported that Tertiary sediments are more than $9.4 \mathrm{~km}$ thick and are primarily Eocene to Miocene in age.

The existence of thick preserved sections of young Brookian sequence sedimentary rocks indicate that it is quite possible that uplifted regions across the Colville basin were once overlain by a thick stratigraphic section. This section was probably removed by uplift and erosion during the Tertiary, the timing of which is indicated by the apatite-fission-track data. In the absence of any other viable explanation and because the estimates of removed section seem plausible, I favor an interpretation of the data in terms of heating due to burial and cooling due to uplift and erosion.

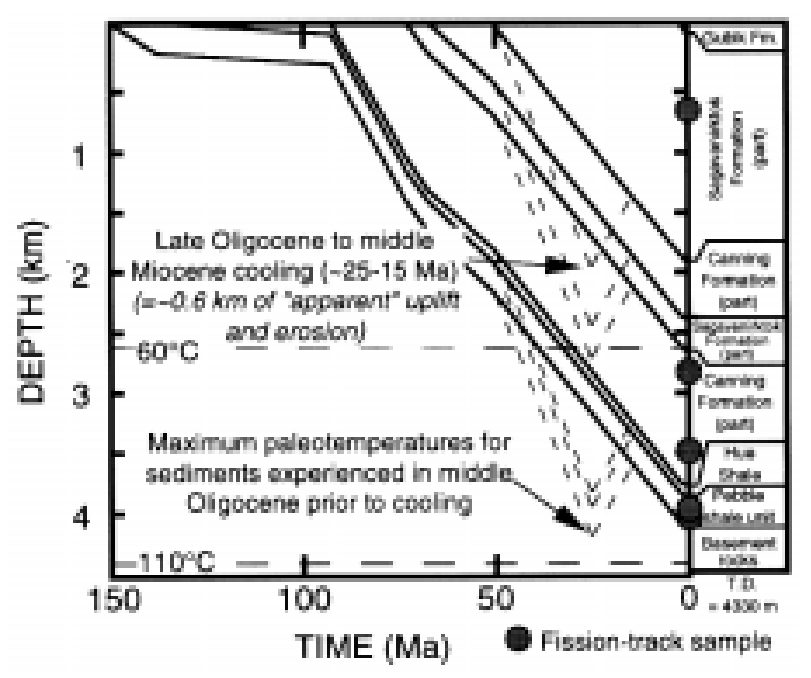

Figure 17. Proposed depositional history for Exxon Alaska State C-1 well based on fission-track, vitrinite-reflectance, and stratigraphic parameters. Solid lines represent true burial history, whereas dashed lines follow the thermal history in relation to prevailing down-hole temperatures. See text for details. 


\section{TIMING OF UPLIFT AND EROSION}

When fission-track results from the Colville basin are plotted with respect to location, obvious trends are seen (fig. $18)$. At some time during the Paleocene to early Eocene ( 65 to $50 \mathrm{Ma})$ compressional deformation resulted in uplift and erosion across most of the Colville basin. It is likely that uplift and erosion at this time is related since it occurred throughout the region south of the present-day coastline. On the basis of well constrained fission-track data from throughout the Brooks Range (Blythe and others, in press; Murphy and others, 1994; O'Sullivan, 1988; O'Sullivan and Decker, 1989; O'Sullivan and others, 1991b, 1992, in press; O'Sullivan, Green and others, 1993), I propose that the event responsible for regional uplift and erosion occurred at $\sim 60 \pm 4 \mathrm{Ma}$.

Apatite-fission-track data from the Colville basin also suggest that an episode of cooling related to uplift and erosion occurred at some time during the middle Oligocene to middle Miocene (between $\sim 30$ and $15 \mathrm{Ma}$ ). Once again, considering the consistency of the results, it is likely that uplift and erosion in all areas of the foreland basin is related. During the late Oligocene much of the core of the Brooks Range and the southern Colville basin experienced another episode of uplift and erosion. Data from the core of the Brooks Range including the Mt. Doonerak antiform (O'Sullivan and others, 1991a, in press; Murphy and O'Sullivan, 1992; Blythe and others, in press), the Okpilak batholith, and the Sadlerochit Mountains (O'Sullivan, 1993; O'Sullivan and others, 1992, in press) suggest that this episode occurred during the late Oligocene at $\sim 25 \pm 3 \mathrm{Ma}$.

Along the northern edge of the Colville basin near the northern coast of Alaska there is no evidence from the preserved stratigraphy that any section was removed during the late Oligocene due to uplift and erosion or lowering of sea level. To explain the data from the Alaska State C-1 well that suggest that $\sim 10^{\circ}$ to $15^{\circ} \mathrm{C}$ of cooling occurred at some time between $\sim 25$ and $15 \mathrm{Ma}$, I propose that the data records an episode of cooling related to the large change in climate from temperate to arctic conditions, which occurred before the end of the Miocene (Clark, 1990).

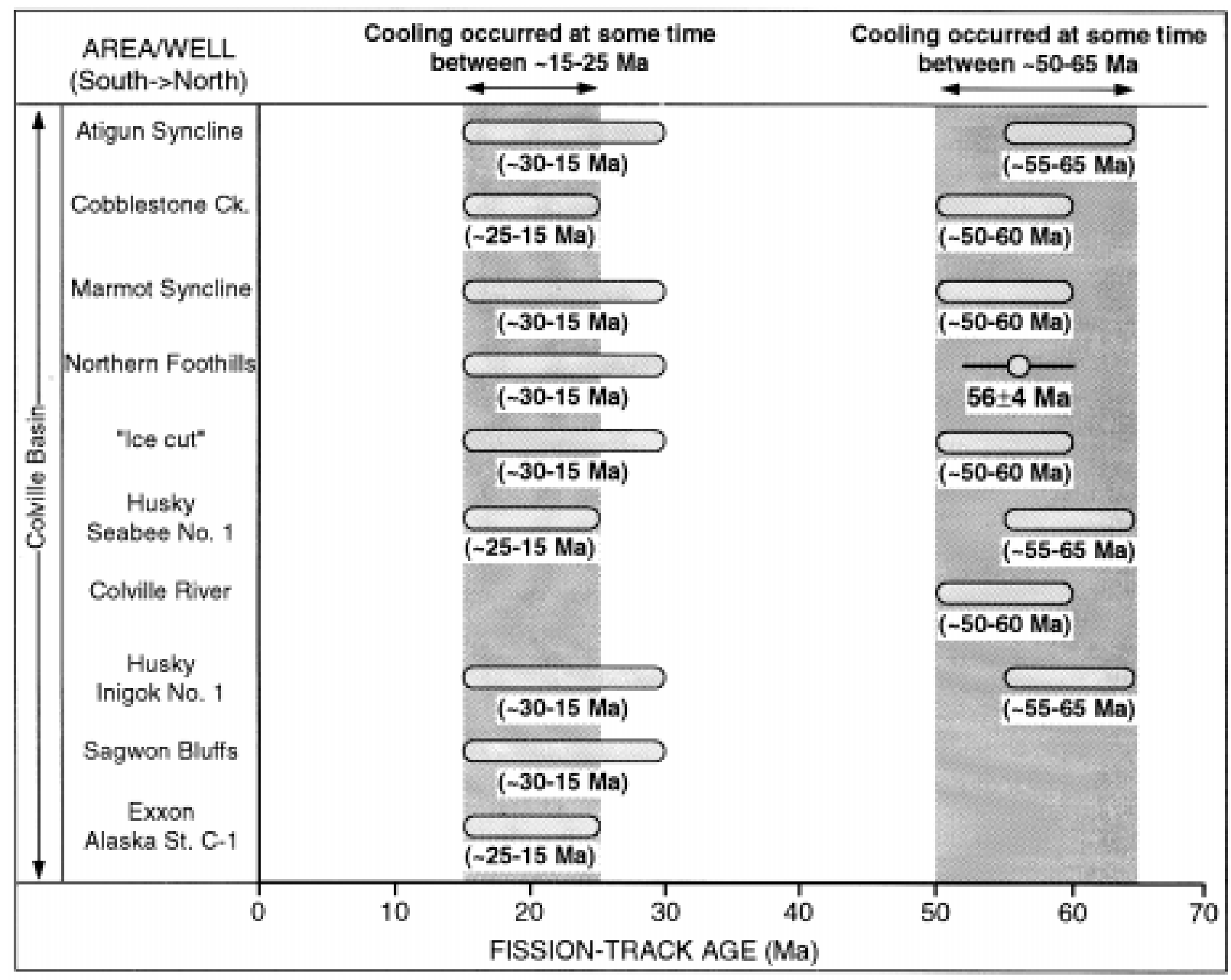

Figure 18. Plot showing timing of rapid cooling events for areas/wells discussed in this study. Resulting trends are discussed in the text. 
In summary, only two major episodes of Cretaceous and Tertiary(?) deformation have been previously recognized for the central Brooks Range and Colville basin (for example, Mull, 1982; Moore and others, 1992, and references therein) (1) an early episode during the Late Jurassic to Early Cretaceous, followed by (2) a second episode during the Late Cretaceous and Tertiary(?). On the basis of fission-track data from the Colville basin, the second episode occurred at $\sim 60 \pm 4$ Ma. Furthermore, the fission-track data suggest that a third major deformation episode occurred at $\sim 25 \pm 3 \mathrm{Ma}$. I propose, therefore, that there were actually three, not two, major episodes of deformation that have affected the North Slope and its foreland basin during the Cretaceous and Tertiary. Deformation and resulting uplift and erosion did occur on the North Slope during the Eocene to early Oligocene, but deformation seems to have been restricted to the northeastern parts of the foreland basin (O'Sullivan, 1993; O'Sullivan and others, 1992; O’Sullivan, Green and others, 1993).

There is little doubt that the initial Late Jurassic to Early Cretaceous orogenic episode was the most dominant event affecting the development of the Brooks Range and the Colville basin. Late Jurassic to Early Cretaceous compression resulted in hundreds of kilometers of structural shortening, many kilometers of uplift and erosion within the mountain belt, and deposition of sediments many kilometers thick in the foreland basin. There is also little doubt that Tertiary deformation is responsible for much of the present topography in the northeastern Brooks Range (O'Sullivan and others, in press). I propose that much of the present-day topography in the central and western Brooks Range and across the Colville basin is probably the result of tectonically-driven Tertiary uplift and erosion during the Paleocene and the late Oligocene.

This interpretation conflicts with the tectonic model for development of the Brooks Range and Colville basin proposed by Howell and others (1992), who suggested that Tertiary uplift and erosion occurred in response to postconvergence crustal rebound. Their interpretation is based on the position of the 0.6 and 2.0 percent vitrinitereflectance isograds, which if projected southward across the North Slope foreland basin and into the core of the Brooks Range (for example, Bird and Molenaar, 1992, their Fig. 15), suggest that the core of the Brooks Range has experienced much more uplift and erosion than the adjoining foreland basin. Fission-track data from two areas in particular, however, suggest that compression was responsible for episodes of Paleocene and late Oligocene uplift and erosion. First, as seen in figure 8 , the ages of samples from rocks exposed in the cores of the anticlines south of Umiat have all been reset and record the rapid cooling episode during the Paleocene, whereas samples from rocks exposed in the synclines give depositional ages. This relation suggests that rapid cooling was related to a compressional event that folded and faulted the area. Next, data from samples collected within the core of the Brooks Range (O'Sullivan and others, 1991a,b, in
Table 1. Timing and amount of Tertiary uplift and erosion. [Leaders ( - ), indicate no value determined]

\begin{tabular}{|c|c|c|c|c|c|}
\hline $\begin{array}{c}\text { Area } \\
\text { or well }\end{array}$ & $\begin{array}{c}60 \\
\text { Temp. } \\
\left({ }^{\circ} \mathrm{C}\right) \\
\end{array}$ & $\begin{array}{c} \pm 4 \\
\mathrm{Ma} \\
(\mathrm{km})^{1}\end{array}$ & $\begin{array}{c}25 \pm 3 \\
\mathrm{Ma} \\
(\mathrm{km})^{2}\end{array}$ & $\begin{array}{l}\text { Upparent" } \\
\text { Uplift } \\
(\mathrm{km})^{3}\end{array}$ & $\begin{array}{l}\text { Total } \\
(\mathrm{km})^{4}\end{array}$ \\
\hline Atigun Sy & & & 1 & & \\
\hline & & & & & \\
\hline $\mathrm{k}$ & 1 & 2 & 1.3 & & \\
\hline 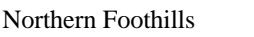 & 125 & 2 & 1.0 & & \\
\hline & 75 & & --- & & \\
\hline 1 & 70 & $(0-1$ & 0.5 & & 2. \\
\hline Husky in & 45 & $0-1$ & --- & & 1 . \\
\hline $\mathrm{Sa}$ & 75 & --- & 2.0 & & 2. \\
\hline Exxon Alaska State C-1 & 5 & --- & --- & & -- \\
\hline \multicolumn{6}{|c|}{$\begin{array}{l}1 \text { Timing of Paleocene and late Oligocene uplift and erosion at } \sim 60 \pm 4 \text { Ma based on } \\
\text { regional correlation of values of uplift and erosion across the Colville basin, } \\
\text { including (O'Sullivan, 1988; O'Sullivan and Decker, 1989; O'Sullivan and others, } \\
\text { 1992, 1993). }\end{array}$} \\
\hline \multicolumn{6}{|c|}{$\begin{array}{l}2 \text { Timing of late Oligocene uplift and erosion at } \sim 25 \pm 3 \text { Ma based on regional } \\
\text { correlation of values of uplift and erosion across the Colville basin, including Mt. } \\
\text { Doonerak antiform (O'Sullivan and others, 1991, in press), and from the Okpilak } \\
\text { batholith, Sadlerochit Mountains, and Ignek Valley areas (O'Sullivan and others, } \\
\text { 1993). }\end{array}$} \\
\hline \multicolumn{6}{|c|}{$\begin{array}{l}3 \text { Value of "apparent" uplift and erosion in response to change in mean annual surface } \\
\text { temperature at some time between } \sim 20 \text { and } 10 \mathrm{Ma} \text {. }\end{array}$} \\
\hline \multicolumn{6}{|c|}{$\begin{array}{l}4 \text { Estimated values of total uplift and erosion (1) are calculated using the estimated } \\
\text { maximum paleotemperature (determined from fission-track or vitrinite-reflectance } \\
\text { data) and the paleogeothermal gradient and (2) do not include estimated "apparent" } \\
\text { uplift and erosion. }\end{array}$} \\
\hline
\end{tabular}

press; O'Sullivan, Murphy and others, 1993; Murphy and O'Sullivan, 1992; Blythe and others, in press) have apatitefission-track ages that record rapid cooling during the late Oligocene. These rocks are presently located structurally above (as interpreted by Oldow and others, 1987; Moore and others, 1992) and topographically higher than rocks located within the Brooks Range that record cooling during the Albian and above rocks located along the northern foothills of the Brooks Range that record cooling during the Paleocene. This relation, which cannot be explained by simple crustal rebound, suggests that a major compression event occurred during the late Oligocene.

Therefore, as suggested by Howell and others (1992), the core of the Brooks Range has experienced much more uplift than have the foothills to the north. The reason, however, that the core of the Brooks Range has been uplifted much more is not totally the result of crustal isostasy (postconvergent orogenic phase of Howell and others, 1992) but is primarily the result of Paleocene and late Oligocene deformation. However, this does not mean that the core of the Brooks Range has not experienced some component of crustal rebound during the Tertiary.

\section{AMOUNTS OF UPLIFT AND EROSION}

Table 1 lists estimates of uplift and erosion experienced throughout the central Colville basin during each cooling episode during the Tertiary. The total amount of uplift and erosion required to allow the areas/wells listed in table 1 to cool from maximum paleotemperatures, not including apparent uplift and erosion resulting from a decrease in mean 

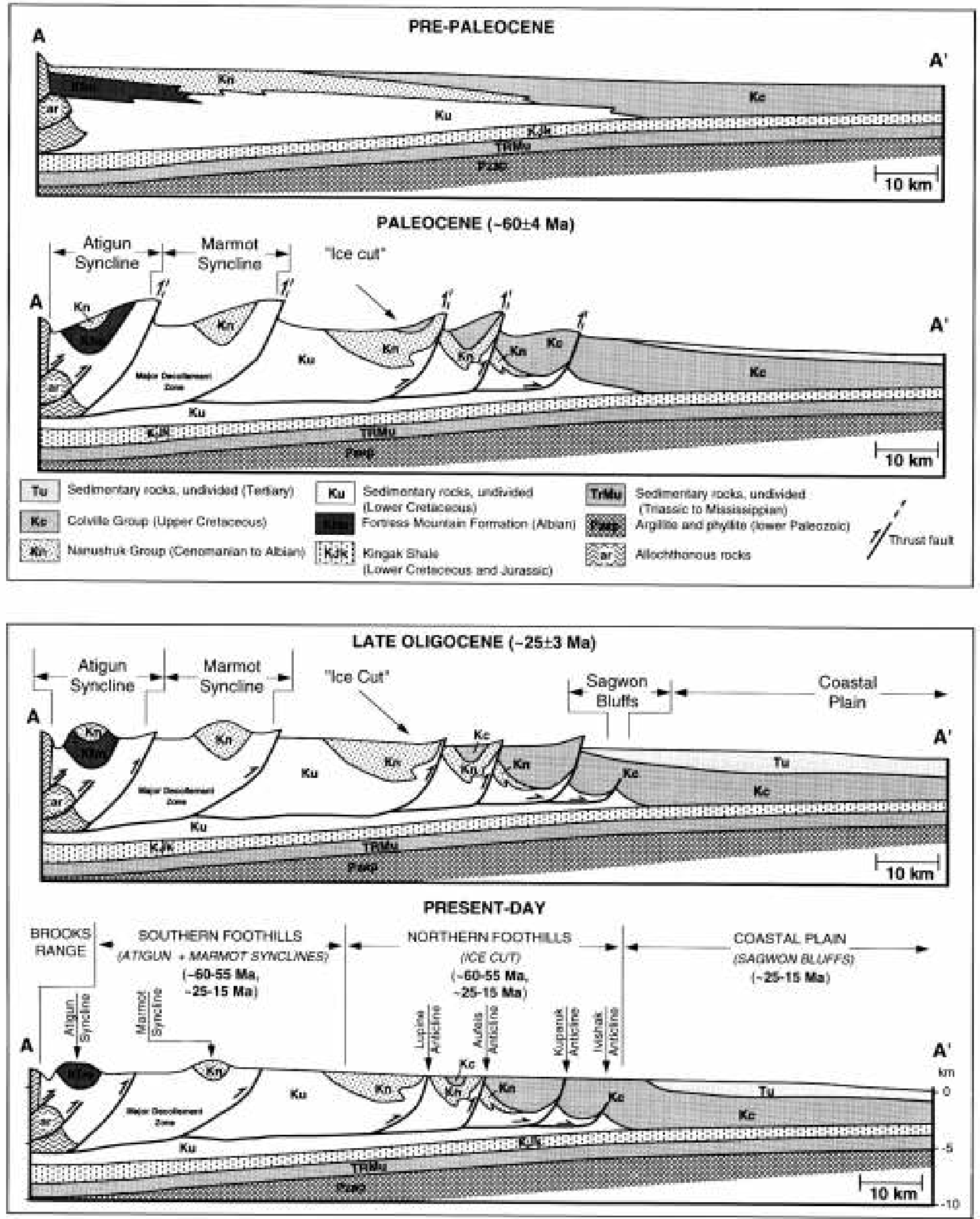

Figure 19. Schematic illustrations of tectonic history interpretations for a cross-section along the Sagavanirktok River region using fission-track data from areas/wells discussed in this study. Details discussed within the text. Present-day cross section modified after Mull and Adams (1989). 
annual surface temperature, ranges between $\sim 3$ and $4 \mathrm{~km}$ within the northern foothills of the Brooks Range and between $\sim 0$ and $2.5 \mathrm{~km}$ northward across the North Slope coastal plain. These values are consistent with the amount of uplift and erosion within the northern foothills of the Brooks Range of between $\sim 3$ and $5 \mathrm{~km}$ proposed by Howell and others (1992). The amount of apparent uplift and erosion resulting from a decrease in mean annual surface temperature experienced by each of the areas/wells listed in Table 1, estimated on the basis of the geothermal gradient and the decrease in mean annual surface temperature, ranges between $\sim 0.3$ and 0.6 $\mathrm{km}$.

\section{REGIONAL SYNTHESIS}

I propose that the north-south variation in apatite-fission-track ages across the Colville basin can be interpreted in terms of progressive uplift and erosion during the Tertiary within the advancing deformation front. To show the presentday lateral variation in time of uplift and erosion, fissiontrack results have been projected into a regional cross-section along the Sagavanirktok River (fig. 19). Two uplift and erosion events have occurred during the Tertiary at $\sim 60 \pm 4$ $\mathrm{Ma}$ and at $\sim 25 \pm 3 \mathrm{Ma}$. Compression during the Paleocene resulted in the formation of a series of imbricate thrust faults from a basal detachment surface in the Torok Formation. At this time, allochthonous rocks presently exposed along Cobblestone Creek and autochthonous and parautochthonous rocks exposed in Atigun Syncline, Marmot Syncline, and along the Sagavanirktok and Colville rivers as far north as the "Ice cut" and Seabee No. 1 well were rapidly cooled, owing to at least $\sim 2 \mathrm{~km}$ of uplift and erosion, from elevated paleotemperatures $\geq 105^{\circ}$ to $\sim 50^{\circ} \mathrm{C}$. Subsequently, during the late Oligocene to Miocene, the Colville basin experienced $\sim 0.5$ to $2.0 \mathrm{~km}$ of uplift and erosion, as well as between $\sim 0.3$ and $0.6 \mathrm{~km}$ of apparent uplift and erosion resulting from a decrease in mean annual surface temperature.

As seen from figure 19 and table 1, areas along the northern foothills of the Brooks Range have experienced higher amounts of relative uplift and erosion than those to the north, as Howell and others (1992) have proposed. The fission-track data presented here, however, suggest that isostatic rebound was not the dominating mechanism for the uplift and erosion. In fact the regional data suggest that two episodes of rapid uplift and erosion within the Brooks Range during the Tertiary have also affected the thermotectonic history of the Colville basin, with areas along the southern part of the foreland basin closer to the mountain front experiencing relatively more cooling in response to uplift and erosion than those areas further to the north. Along the northern coast of Alaska, where no uplift and erosion has occurred, the change in surface temperature from $\sim 5^{\circ}$ to $\sim-10^{\circ} \mathrm{C}$ from the early to middle Miocene to the present resulted in $\sim 15^{\circ} \mathrm{C}$ of cooling throughout the preserved section even though the area experienced continuous deposition during that time period.

\section{ACKNOWLEDGMENTS}

This work was made possible with partial funding by the Minerals Management Service Continental Margins Project (Cooperative Agreement No. 14-12-0001-30432) and a La Trobe University postgraduate scholarship. Support for sample irradiations was supplied through a grant to the $\mathrm{La}$ Trobe University Fission-Track Research Group from the Australian Institute of Nuclear Science and Engineering. Field and logistical support was provided by the State of Alaska Division of Geological and Geophysical Surveys. Partial support for sample processing and shipping was provided by ARCO Oil and Gas. The author would like to thank Prof. A.J.W. Gleadow and Dr. P.F. Green for originally reviewing the results and interpretations made in this manuscript prior to submittal, and Barry Kohn, John Murphy, David Howell, David Deming, and Jim Hendley for their comments during review.

\section{REFERENCES CITED}

Bayliss, G.F., and Magoon, L.B., 1988, Organic facies and thermal maturity of sedimentary rocks in the National Petroleum Reserve in Alaska, in Gryc, George, ed., Geology and exploration of the National Petroleum Reserve in Alaska, 1974 to 1982: U.S. Geological Survey Professional Paper 1399, p. 489-518.

Bird, K.J., 1987, The framework geology of the North Slope of Alaska as related to oil-source rock correlations, in Tailleur, I.L. and Weimer, P., eds., Alaskan North Slope Geology: Society of Economic Paleontologists and Mineralogists Pacific Section Publication 50, p. 121-143.

1988, Alaskan North Slope stratigraphic nomenclature and data summary for government-drilled well, in Gryc, George, ed., Geology and exploration of the National Petroleum Reserve in Alaska, 1974 to 1982: U.S. Geological Survey Professional Paper 1399, p. 317-354.

1991a, Geology, play descriptions, and petroleum resources of the Alaskan North Slope (petroleum provinces 58-60): U.S. Geological Survey Open-File Report 88-450Y, 52 p.

1991b, North Slope of Alaska, in Gluskoter, H.J., Rice, D.D., and Taylor, R.B., eds., Economic geology, U.S., oil and gas section, part III, Regional synthesis of selected provinces, chapter 29: Boulder, Colorado, Geological Society of America, The Geology of North America, v. P-2, p. 447-462.

Bird, K.J., and Bader, J.W., 1987, Regional geologic setting and history of petroleum exploration, in Bird, K.J., and Magoon, L.B., eds., Petroleum geology of the northern part of the Arctic National Wildlife Refuge, Northeastern Alaska: U.S. Geological Survey Bulletin 1778, p. 17-25.

Bird, K.J., and Magoon L.B., eds., 1987, Petroleum geology of the northern part of the Arctic National Wildlife Refuge, northeastern Alaska: U.S. Geological Survey Bulletin 1778, 329 p.

Bird, K.J., and Molenaar, C.M., 1987, Stratigraphy, in Bird, K.J., 
and Magoon, L.B., eds., Petroleum Geology of the northern part of the Arctic National Wildlife Refuge, Northeastern Alaska: U.S. Geological Survey Bulletin 1778, p. 37-59.

1992, The North Slope foreland basin, Alaska, in Macqueen, R.W., and Leckie, D.A., eds., Foreland Basins and Foldbelts: American Association of Petroleum Geologists Memoir 55, p. 363-393.

Bird, K.J., Conner, C.L., Tailleur, I.L., Silberman, M.L., and Christie, J.L., 1978, Granite on the Barrow Arch, northeast NPRA, in Johnson, K.M., ed., The United States Geological Survey in Alaska: Accomplishments during 1977: U.S. Geological Survey Circular 772-B, p. B24-B25.

Blythe, A.E., Bird, J.M., and Omar, G.I., in press, Cooling history of the central Brooks Range, Alaska, from fission-track and ${ }^{40} \mathrm{Ar} /{ }^{39} \mathrm{Ar}$ analyses: Geological Society of America Special Publication on the Central Brooks Range.

Box, S.E., 1985, Early Cretaceous orogenic belt in northeastern Alaska: internal organization, lateral extent, and tectonic interpretation, in Howell, D.G., ed., Tectonostratigraphic Terranes of the Circum-Pacific Region: Circum-Pacific Council for Energy and Mineral Resources Earth Sciences Series, no. 1, p. 137-145.

Box, S.E., and Patton, W.W., Jr., 1987, Early Cretaceous evolution of the Yukon-Koyukuk basin and its bearing on the development of the Brookian orogenic belt, Alaska (abs.), in Tailleur, I.L., and Weimer, P., eds., Alaskan North Slope Geology: Society of Economic Paleontologists and Mineralogists Pacific Section Publication 50, p. 883.

Bray, R.J., Green, P.F., and Duddy, I.R., 1992, Thermal history reconstruction using apatite fission track analysis and vitrinite reflectance: A case study from the East Midlands of England and the southern North Sea, in Hardman, R.S.P., ed., Exploration Britain: Geological insights for the next decade: Geological Society Of London Special Publication 67, p. 3-25.

Brosge, W.P., and Tailleur, I.L., 1970, Depositional history of northern Alaska, in Adkison, W.L., and Brosge, M.M., eds., Proceedings of the geological seminar on the North Slope of Alaska: American Association of Petroleum Geologists Pacific Section Meeting, Los Angeles, p. D1-D18.

Bruns, T.R., Fisher, M.A., Leinbach, W.J., and Miller, J.J., 1987, Regional structure of rocks beneath the coastal plain, in Bird, K.J., and Magoon, L.B., eds., Petroleum Geology of the northern part of the Arctic National Wildlife Refuge, Northeastern Alaska: U.S. Geological Survey Bulletin 1778, p. 249-254.

Burnham, A.K., and Sweeney, J.J., 1989, A chemical kinetic model of vitrinite maturation and reflectance: Geochimica et Cosmochimica Acta, v. 53, p. 2649-2657.

Clark, D.L., 1982, Origin, nature, and world climate effect of Arctic Ocean ice-cover: Nature, v. 300, p. 321-325.

1990, Arctic Ocean ice cover; geologic history and climatic significance, in Grantz, A., Johnson, L., and Sweeney, J.F., eds., The Arctic Ocean region: Geological Society of America, The Geology of North America, v. L: 53-62.

Deming, D., Sass, J.S., Lachenbruch, A.H., and De Rito, R.F., 1992, Heat flow and subsurface temperature as evidence for basinscale groundwater flow, North Slope of Alaska: Geological Society of America Bulletin, v. 104, n. 5, p. 528-542.

Detterman, R.L., Reiser, H.N., Brosge, W.P., and Dutro, J.T., Jr., 1975, Post-Carboniferous stratigraphy, Northeastern Alaska: U.S. Geological Survey Professional Paper 886, 46 p.

Dillon, J.T., Pessel, G.H., Chen, J.A., and Veach, N.C., 1980, Middle
Paleozoic magmatism and orogenesis in the Brooks Range, Alaska: Geology, v. 8, p. 338-343.

Dillon, J.T., Tilton, G.R., Decker, J., and Kelly, M.J., 1987, Resource implications of magmatic and metamorphic ages for Devonian igneous rocks in the Brooks Range, in Tailleur, I.L., and Weimer, P., eds., Alaskan North Slope Geology: Society of Economic Paleontologists and Mineralogists Pacific Section Publication 50, p. 713-723.

Duddy, I.R., Green, P.F., and Laslett, G.M., 1988, Thermal annealing in fission tracks 3: Variable temperature behaviour: Chemical Geology (Isotope Geoscience Section), 73, p. 25-38.

Engebretson, D.C., Cox, A., and Gordon, R.G., 1985, Relative motions between oceanic and continental plates in the Pacific basin: Geological Society Of America, Special Paper 206, 59 p.

Fleischer, R.L., Price, P.B., and Walker, R.M., 1975, Nuclear tracks in solids: Principles and applications: University of California Press, Berkeley, 605 p.

Galbraith, R.F., 1981, On statistical models for fission track counts: Mathematical Geology, v. 13, p. 471-488.

Galbraith, R.F., 1988, Graphical display of estimates having differing standard errors: Technometrics, v. 30, p. 271-281.

Gleadow, A.J.W., 1984, Fission track dating methods-II: a manual of principles and techniques. Workshop on fission track analysis: principles and applications: James Cook University, Townsville, Australia, 4-6 September 1984, 35 p

Gleadow, A.J.W., and Duddy, I.R., 1984, Fission track dating and thermal history analysis of apatites from wells in the northwest Canning Basin, in Purcell, P.G., ed., The Canning Basin, W. A.: Proceedings of the Geological Society of Australia and Petroleum Exploration Society of Australia Symposium, Perth, 1984, p. 377-387.

Gleadow, A.J.W., Duddy, I.R., and Lovering, J.F., 1983, Fission track analysis: a new tool for the evaluation of thermal histories and hydrocarbon potential: Petroleum Exploration Association of Australia Journal, v. 23, p. 93-102.

Gleadow, A.J.W., Duddy, I.R., Green, P.F., and Lovering J.F., 1986, Confined fission track lengths in apatite: a diagnostic tool for thermal history analysis: Contributions to Mineral Petrology, v. 94 , p. 405-415.

Gottschalk, R.R., and Oldow, J.S., 1989, Low-angle normal faults in the south-central Brooks Range fold and thrust belt, Alaska: Geology, v. 16, p. 395-399.

Grantz, A., and May, S.D., 1983, Rifting history and structural development of the continental margin north of Alaska, in Watkins, J.S., and Drake, C.L., eds., Studies in Continental Margin Geology: American Association of Petroleum Geologists Memoir 34, p. 77-100.

Green, P.F., 1981, A new look at statistics in fission track dating: Nuclear Tracks, v. 5, p. 77-86.

1986, On the thermo-tectonic evolution of northern England: evidence from fission track analysis: Geology, v. 5, p. 493506.

1989, Thermal and tectonic history of the East Midlands shelf (onshore UK), and surrounding regions assessed by apatite fission track analysis: Journal of the Geological Society of London, v. 146, p. 755-773.

Green, P.F., Duddy, I.R., Gleadow, A.J.W., Tingate, P.T., and Laslett, G.M., 1985, Fission-track annealing in apatite: track length measurements and the form of the Arrhenius plot: Nuclear Tracks, v. 10, p. 323-328.

Green, P.F., Duddy, I.R., Gleadow, A.J.W., Tingate, P.T., and Laslett, 
G.M., 1986, Thermal annealing of fission tracks in apatite: 1-a qualitative description: Isotope Geoscience, v. 59, p. 237-253.

Green, P.F., Duddy, I.R., Gleadow, A.J.W., and Lovering, J.F., 1989, Apatite fission track analysis as a paleotemperature indicator for hydrocarbon exploration, in Naeser, N.D., ed., Thermal history of sedimentary basins-methods and case histories: Springer-Verlag, New York, p. 181-195.

Green, P.F., Duddy, I.R., Laslett, G.M., Hegarty, K.A., Gleadow, A.J.W., and Lovering, J.F., 1989, Thermal annealing of fission tracks in apatite 4. Qualitative modeling techniques and extensions to geological timescales: Chemical Geology (Isotope Geoscience Section), v. 79, p. 155-182.

Harland, W.B., Armstrong, R.L., Cox, A.V., Craig, L.E., Smith, A.G., and Smith, D.G., 1990, A geologic time scale 1989: Cambridge University Press, Cambridge, $263 \mathrm{p}$.

Howell, D.G., Bird, K.J., Huafu, L., and Johnsson, M.J., 1992, Tectonics and petroleum potential of the Brooks Range fold and thrust belt: a progress report, in Bradley, D.C., and Ford, A.B., eds., Geologic studies in Alaska by the U.S. Geological Survey during 1990: U.S. Geological Survey Bulletin 1999, p. 112-126.

Hubbard, R.J., Edrich, S.P., and Rattey, R.P., 1987, Geologic evolution and hydrocarbon habitat of the "Arctic Alaska Microplate", in Tailleur, I.L., and Weimer, P., eds., Alaskan North Slope Geology: Society of Economic Paleontologists and Mineralogists Pacific Section Publication 50, p. 797-830.

Hurford, A.J., and Green, P.F., 1982, A users' guide to fission-track dating calibration: Earth and Planetary Science Letters, v. 59, p. 343-354.

1983, The zeta calibration of fission track dating: Isotope Geoscience, v. 1, p. 285-317.

Johnsson, M.J., Pawlewicz, J., Harris, A.G., and Valin, Z. C., 1992, Vitrinite reflectance and conodont color alteration index data from Alaska: U.S. Geological Survey Open-file Report 92-409, 3 computer disks.

Lachenbruch, A.H., Sass, J.H., Lawver, L.A., Brewer, M.C., Marshall, B.V., Munroe, R.J., Kennelly, J.P., Galanis, S.P., and Moses, T.H. Jr., 1988, Temperature and depth of permafrost on the Arctic slope of Alaska, in Gryc, George, ed., Geology and exploration of the National Petroleum Reserve in Alaska, 1974 to 1982: U.S. Geological Survey Professional Paper 1399, p. 645-656.

Lal, D., Rajan, R.S., and Tamhane, A.S., 1969, Chemical composition of nuclei of $\mathrm{Z}>22$ in cosmic rays using meteoric minerals as detectors: Nature, v. 221, p. 3337.

Laslett, G.M., Green, P.F., Duddy, I.R., and Gleadow, A.J.W., 1987, Thermal modeling of fission tracks in apatite 2 . A quantitative analysis: Chemical Geology, v. 65, p. 113.

Lee, T., 1979, Erosion, uplift, exponential heat source distribution, and transient heat flux: Journal of Geophysical Research, v. 84, p. 585-590.

Lerand, M., 1973, Beaufort Sea, in McCrossan, R.G., ed., The future petroleum provinces of Canada-their geology and potential: Canadian Society Petroleum Geolo- gists Memoir 1, p. 315-386.

Lopatin, N.V., 1971, Temperature and geologic time as factors in coalification (in Russian): Akademiia Nauk SSSR Izvestiia Seriia Geologicheskaia, no. 3, p. 95-106.

Magoon, L.B., Bird, K.J., Claypool, G.E., Weitzman, D.E., and Thompson, R.H., 1988, Organic geochemistry, hydrocarbon occurrence, and stratigraphy of governmentdrilled wells, North Slope, Alaska, in Gryc, George, ed., Geology and exploration of the National Petroleum Reserve in Alaska, 1974 to 1982: U.S. Geological Survey Professional Paper 1399, p. 483-487, 39 plates.

Mayfield, C.F., Tailleur, I.L., and Ellersiech, I., 1988, Stratigraphy, structure, and palinspastic synthesis of the western Brooks Range, northwestern Alaska, in Gryc, George, ed., Geology and exploration of the National Petroleum Reserve in Alaska, 1974 to 1982: U.S. Geological Survey Professional Paper 1399, p. 143-186.

Mayfield, C.F., Tailleur, I.L., and Kirschner, C.E., 1988, Bedrock geologic map of the National Petroleum Reserve in Alaska, in Gryc, George, ed., Geology and exploration of the National Petroleum Reserve in Alaska, 1974 to 1982: U.S. Geological Survey Professional Paper 1399, p. 187-190, 2 plates.

McMillen, K.J., and O’Sullivan, P.B., 1992, Tectonic and eustatic controls on Paleogene sequence stratigraphy: Beaufort Sea, Alaska and Canada, in Watkins, J.S., Zhiqiang, F, and McMillen, K.J., eds., Geology and geophysics of continental margins: American Association of Petroleum Geologists Memoir 53, p. 285-301.

Moore, T.E., Wallace, W.K., Bird, K.J., Karl, S.M., Mull, C.G., and Dillon, J.T., 1992, Stratigraphy, structure, and geologic synthesis of northern Alaska: U.S. Geological Survey Open-File Report 92-330, 183 p., 1 sheet.

Mull, C.G., 1982, Tectonic evolution and structural style of the Brooks Range and Arctic Slope, Alaska, in Powers, R.B., ed., Geologic studies of the Cordilleran Thrust belt: Rocky Mountain Association of Geologists, Denver, Colorado, v. 1, p. 1-45.

1985, Cretaceous tectonics, depositional cycles, and the Nanushuk Group, Brooks Range and Arctic Slope, Alaska, in Huffman, A.C. Jr., ed., Geology of the Nanushuk Group and related rocks, North Slope, Alaska: U.S. Geological Survey Bulletin 1614, p. 7-36.

1989, Stratigraphy and structure of the Brooks Range and Arctic Slope, in Mull C.G., and Adams, K.E., eds., Dalton Highway, Yukon River to Prudhoe Bay, Alaska: Alaska Geological and Geophysical Surveys, Guidebook 7, v. 1, p. 31-46.

Mull, C.G., and Adams, K.E., eds., 1989, Dalton Highway, Yukon River to Prudhoe Bay, Alaska: Alaska Geological and Geophysical Surveys, Guidebook 7, 2 volumes, $309 \mathrm{p}$.

Murphy, J.M., and O'Sullivan, P.B., 1992, Early Cretaceous to Late Tertiary tectonics and uplift in the central Brooks Range, Alaska-Apatite fission track studies (abs.) in Abstracts Volume: American Association of Petroleum Geologists 1992 Annual Convention, Calgary, British Columbia, June, 1992, p. 94.

Murphy, J.M., O’Sullivan, P.B., and Gleadow, A.J.W., 1994, Apatite fission track evidence of episodic Early Cretaceous to Late Tertiary cooling and uplift, central Brooks 
Range, Alaska, in Thurston, D., and Fujita, K., eds., 1992 Proceedings International Conference on Arctic Margins: U.S. Minerals Management Service Outer Continental Shelf Study 94-0040, p. 257-262.

Naeser, C.W., 1979, Fission track dating and geologic annealing of fission tracks, in Jager, E., and Hunziker, J.C., eds., Lectures in Isotope Geology: Springer Verlag, New York, p. 154-169.

Oldow, J.S., Seidensticker, C.M., Phelps, J.C., Julian, F.E., Gottschalk, R.R., Boler, K.W., Handschy, J.W., and Ave Lallement, H.G., 1987, Balanced cross sections through the central Brooks Range and North Slope, Arctic Alaska: American Association of Petroleum Geologists Publication, 19 p., 8 plates.

Omar, G.I., Steckler, M.S., Buck, W.R., and Kohn, B.P., 1989, Fission-track analysis of basement apatites at the western margin of the Gulf of Suez rift, Egypt: Evidence for synchroneity of uplift and subsidence: Earth and Planetary Science Letters, v. 94, p. 316-328.

O'Sullivan, P.B., 1988, Apatite fission track study of the thermal history of Permian to Tertiary sedimentary rocks in the Arctic National Wildlife Refuge, Northeastern Alaska (University of Alaska-Fairbanks M.S. thesis): Alaska Geological and Geophysical Surveys Public Data File 88-42, $184 \mathrm{p}$.

- 1991, Timing of tectonic events on the North Slope of Alaska by apatite fission track analysis, and a comparison between these tectonic events and the offshore sedimentary record: Alaska Geological and Geophysical Surveys Public Data File 91-13, 147 p.

1993, Late Cretaceous and Tertiary thermal and uplift history of the North Slope foreland basin of northern Alaska and northwestern Canada: Ph.D. dissertation, La Trobe University, 419 p.

O'Sullivan, P.B., and Decker, John, 1989, Apatite fission track evidence for Paleocene and Oligocene uplift events in the northeastern Brooks Range, Alaska: Nuclear Tracks, no. 3, p. 367-372.

O'Sullivan, P.B., Decker, John, and Bergman, S.C., 1990, Two phases of Tertiary uplift in the Umiat-Colville River region, North Slope, Alaska: an apatite fission track study (abs.): Geological Association of Canada Program with Abstracts, v. 15, p. 98.

O’Sullivan, P.B., Murphy, J.M., and Moore, T.M., 1991a, Apatite fission track evidence for Tertiary uplift in the Doonerak Fenster region, central Brooks Range, Alaska (abs.), in EOS: American Geophysical Union 1991 Fall Meeting Programs and Abstracts, v. 19, n. 44, p. 299.

- 1991b, Evidence for two phases of uplift, during the Albian and Paleocene, in the Atigun Pass and Killik River regions, Brooks Range, Alaska (abs.), in EOS: American Geophysical Union 1991 Fall Meeting Programs and Abstracts, v. 19, n. 44, p. 299.

O'Sullivan, P.B., Green, P.F., Duddy, I.R., and Wallace, W.K., 1992, Timing of deformation along a section through the northeastern Brooks Range, Alaska (abs.), in 1992 International Conference on Arctic Margins Program, Anchorage, Alaska, September, 1992, p. 46.

O'Sullivan, P.B., Green, P.F., Bergman, S.C., Decker, John, Duddy, I.R., Gleadow, A.J.W., and Turner, D.L., 1993, Multiple phases of Tertiary uplift in the Arctic National
Wildlife Refuge, Alaska, based on apatite fission track analysis: American Association of Petroleum Geologists Bulletin, v. 77, n. 3, p. 359-385.

O'Sullivan, P.B., Murphy, J.M., Moore, T.E., and Howell, D.G., 1993, Results of 110 apatite fission track analyses from the Brooks Range and North Slope of northern Alaska, completed in cooperation with the Trans-Alaska Crustal Transect (TACT): U.S. Geological Survey OpenFile Report 93-545, 104 p.

O'Sullivan, P.B., Moore, T.M., and Murphy, J.M., in press, Tertiary uplift of the Mt. Doonerak antiform, central Brooks Range, Alaska: Apatite fission track evidence from the Trans-Alaska Crustal Transect: Geological Society of America Memoir on the Central Brooks Range.

Palmer, I.F., Bolmm, J.R., Maxey, L.R., and Lyle, W.M., 1979, Petroleum source rock and reservoir quality data from outcrop samples, onshore North Slope of Alaska east of Prudhoe Bay: U.S. Geological Survey Open-File Report 79-1634, 14 plates, 52 p.

Rattey, R.P., 1987, Northeastern Brooks Range, Alaska-new evidence for complex thin-skinned thrusting (abs), in Tailleur, I.L., and Weimer, P., eds., Alaskan North Slope Geology: Society of Economic Paleontologists and Mineralogists Pacific Section Publication 50, p. 757.

Reifenstuhl, R.R., 1990, Vitrinite reflectance data for some early Tertiary through Jurassic outcrop samples, northeastern Alaska: Alaska Geological and Geophysical Surveys Public Data File 90-5a, 3 p.

Richter, D.H., and Jones, D.L., 1973, Structure and stratigraphy of eastern Alaska Range, Alaska, in Pitcher, M.G., ed., American Association of Petroleum Geologists Memoir 19, p. 408-420.

Roeder, D., and Mull, C.G., 1978, Tectonics of Brooks Range ophiolites, Alaska: American Association of Petroleum Geologists Bulletin, v. 62, p. 1696-1702.

Sieber, K.G., 1986, Compositional variation in apatites: B.S. (honors) thesis, University of Melbourne, $85 \mathrm{p}$.

Smith, D.G., 1987, Late Paleozoic to Cenozoic reconstructions of the Arctic, in Tailleur, I.L., and Weimer, P., eds., Alaskan North Slope Geology: Society of Economic Paleontologists and Mineralogists Pacific Section Publication 50, p. 785-795.

Smith, L., and Chapman, D.S., 1983, On the thermal effects of groundwater flow: 1. Regional scale systems: Journal of Geophysical Research, v. 88, p. 593-608.

Spera, F.J., 1980, Aspects of magma transport, in Hargraves, R.B., ed., Physics of magmatic processes: Princeton University Press, New Jersey, p. 264-323.

Spicer, R.A., 1987, Late Cretaceous floras and terrestrial environment of northern Alaska, in Tailleur, I.L., and Weimer, P., eds., Alaskan North Slope Geology: Society of Economic Paleontologists and Mineralogists Pacific Section Publication 50, p. 497-512.

Turner, D.L., Forbes, R.B., and Dillon, J.T., 1979, K-Ar geochronology of the southwestern Brooks Range, Alaska: Canadian Journal of Earth Sciences, v. 16, no. 9, p. 1789-1804.

Turner, F.J., 1981, Metamorphic petrology: Hemisphere Publishing Corp., New York, New York, 524 p. 
Waples, D.W., 1980, Time and temperature in petroleum formation: Application of Lopatin's method to petroleum exploration: American Association of Petroleum Geologists Bulletin, v. 64, p. 916-926.

Zeitler, P.K., 1985, Cooling history of the NW Himalaya, Pakistan:

Tectonics, v. 4, p. 127-151.

\section{APPENDIX A. INDIVIDUAL SAMPLE INFORMATION.}

Sample details and apatite yields for outcrop samples.

\begin{tabular}{|c|c|c|c|c|c|c|c|}
\hline $\begin{array}{l}\text { Sample } \\
\text { number }\end{array}$ & Long. & Lat. & $\begin{array}{c}\text { Elevation } \\
\mathrm{m} / \mathrm{ft}\end{array}$ & Unit & $\begin{array}{l}\text { Stratigraphic } \\
\text { subdivision } 1\end{array}$ & $\begin{array}{c}\text { Chronostratigraphic } \\
\operatorname{age}^{2}(\mathrm{Ma})\end{array}$ & $\begin{array}{l}\text { Apatite } \\
\text { yield }^{3}\end{array}$ \\
\hline $\begin{array}{l}\text { Atigun Synclin } \\
\text { 89POS102A }\end{array}$ & ex: & $149^{\circ} 23.9^{\prime}$ & $945 / 3100$ & Fortress & Lower Albian & $\sim 105-112$ & Excellent \\
\hline 89POS103A & $68^{\circ} 28.8^{\prime}$ & $149^{\circ} 23.3^{\prime}$ & $1,046 / 3,430$ & $\begin{array}{l}\text { Mountain Fm. } \\
\text { Fortress } \\
\text { Mountain Fm. }\end{array}$ & Lower Albian & $\sim 105-112$ & Excellent \\
\hline 89POS104A & $68^{\circ} 28.9^{\prime}$ & $149^{\circ} 23.1^{\prime}$ & $1,140 / 3,740$ & $\begin{array}{c}\text { Fortress } \\
\text { Mountain Fm. }\end{array}$ & Lower Albian & $\sim 105-112$ & Excellent \\
\hline 89POS105A & $68^{\circ} 29.1^{\prime}$ & $149^{\circ} 22.9^{\prime}$ & $1,259 / 4,130$ & $\begin{array}{c}\text { Fortress } \\
\text { Mountain Fm. }\end{array}$ & Lower Albian & $\sim 105-112$ & Excellent \\
\hline 89POS106A & $68^{\circ} 29.3^{\prime}$ & $149^{\circ} 22.9^{\prime}$ & $1,381 / 4,530$ & $\begin{array}{c}\text { Fortress } \\
\text { Mountain Fm. }\end{array}$ & Lower Albian & $\sim 105-112$ & Excellent \\
\hline 89POS107A & $68^{\circ} 29.1^{\prime}$ & $149^{\circ} 21.4^{\prime}$ & $1,430 / 4,690$ & $\begin{array}{c}\text { Fortress } \\
\text { Mountain Fm. }\end{array}$ & Lower Albian & $\sim 105-112$ & Excellent \\
\hline 89POS108A & $68^{\circ} 36.6^{\prime}$ & $149^{\circ} 40.2^{\prime}$ & $823 / 2,700$ & $\begin{array}{c}\text { Fortress } \\
\text { Mountain Fm. }\end{array}$ & Lower Albian & $\sim 105-112$ & Excellent \\
\hline 89POS109A & $68^{\circ} 37.4^{\prime}$ & $149^{\circ} 38.9^{\prime}$ & $793 / 2,600$ & $\begin{array}{c}\text { Fortress } \\
\text { Mountain Fm. }\end{array}$ & Lower Albian & $\sim 105-112$ & Good \\
\hline 89POS110A & $68^{\circ} 38.1^{\prime}$ & $149^{\circ} 40.6^{\prime}$ & $832 / 2,730$ & $\begin{array}{c}\text { Fortress } \\
\text { Mountain Fm. }\end{array}$ & Lower Albian & $\sim 105-112$ & Good \\
\hline 89POS111A & $68^{\circ} 37.7^{\prime}$ & $149^{\circ} 42.1^{\prime}$ & $768 / 2,520$ & & Lower Albian & $\sim 105-112$ & Excellent \\
\hline 89POS118A & $68^{\circ} 29.8^{\prime}$ & $149^{\circ} 20.0^{\prime}$ & $1,360 / 4,460$ & $\begin{array}{c}\text { Fortress } \\
\text { Mountain Fm. }\end{array}$ & Lower Albian & $\sim 105-112$ & Excellent \\
\hline $\begin{array}{l}\text { Marmot Sync } \\
\text { 88POS30B }\end{array}$ & $\begin{array}{l}\text { ne: } \\
68^{\circ} 43.3^{\prime}\end{array}$ & $149^{\circ} 03.8^{\prime}$ & $713 / 2,340$ & Nanushuk Gp. & $\begin{array}{l}\text { Albian to } \\
\text { Cenomanian }\end{array}$ & 90-112 & Excellent \\
\hline 88POS31A & $68^{\circ} 43.5^{\prime}$ & $149^{\circ} 01.9^{\prime}$ & $765 / 2,510$ & Nanushuk Gp. & $\begin{array}{l}\text { Albian to } \\
\text { Cenomanian }\end{array}$ & $\sim 90-112$ & Excellent \\
\hline 88POS32A & $68^{\circ} 43.5^{\prime}$ & $149^{\circ} 02.1^{\prime}$ & $915 / 3,000$ & Nanushuk Gp. & $\begin{array}{c}\text { Albian to } \\
\text { Cenomanian }\end{array}$ & $\sim 90-112$ & Excellent \\
\hline 88POS33A & $68^{\circ} 43.9^{\prime}$ & $149^{\circ} 03.0^{\prime}$ & $1,110 / 3,640$ & Nanushuk Gp. & $\begin{array}{c}\text { Albian to } \\
\text { Cenomanian }\end{array}$ & $\sim 90-112$ & Excellent \\
\hline 88POS34A & $68^{\circ} 44.6^{\prime}$ & $149^{\circ} 02.7^{\prime}$ & $1,223 / 4,010$ & Nanushuk Gp. & $\begin{array}{l}\text { Albian to } \\
\text { Cenomanian }\end{array}$ & $\sim 90-112$ & Excellent \\
\hline 89POS96A & $68^{\circ} 42.2^{\prime}$ & $148^{\circ} 43.3^{\prime}$ & $1,299 / 4,260$ & $\begin{array}{c}\text { Fortress } \\
\text { Mountain Fm. }\end{array}$ & Lower Albian & $\sim 105-112$ & Excellent \\
\hline 89POS97A & $68^{\circ} 42.5^{\prime}$ & $148^{\circ} 44.0^{\prime}$ & $1,067 / 3,500$ & $\begin{array}{c}\text { Fortress } \\
\text { Mountain Fm. }\end{array}$ & Lower Albian & $\sim 105-112$ & Excellent \\
\hline 89POS98A & $68^{\circ} 42.9^{\prime}$ & $148^{\circ} 44.0^{\prime}$ & $915 / 3,000$ & $\begin{array}{l}\text { Kongakut Fm. } \\
\text { or Torok Fm. }\end{array}$ & Lower Albian & 105-112 & Fair \\
\hline 89POS99A & $68^{\circ} 43.9^{\prime}$ & $148^{\circ} 46.2^{\prime}$ & $640 / 2,100$ & $\begin{array}{l}\text { Fortress Mtn. } \\
\text { Mountain Fm. }\end{array}$ & Lower Albian & $\sim 105-112$ & Excellent \\
\hline $\begin{array}{l}\text { Colville Riv } \\
\text { 88POS35A }\end{array}$ & $69^{\circ} 23.3^{\prime}$ & $152^{\circ} 01.3^{\prime}$ & $76 / 250$ & Colville Gp. & $\begin{array}{c}\text { Cenomanian to } \\
\text { Maastrichtian }\end{array}$ & $\sim 65-97$ & Excellent \\
\hline 88POS36A & $69^{\circ} 23.1^{\prime}$ & $151^{\circ} 58.6^{\prime}$ & $84 / 275$ & Colville Gp. & $\begin{array}{c}\text { Cenomanian to } \\
\text { Maastrichtian }\end{array}$ & $\sim 65-97$ & Very Good \\
\hline 88POS37A & $69^{\circ} 24.3^{\prime}$ & $151^{\circ} 52.1^{\prime}$ & $76 / 250$ & Colville Gp. & $\begin{array}{c}\text { Cenomanian to } \\
\text { Maastrichtian }\end{array}$ & $\sim 65-97$ & Very Good \\
\hline 88POS41A & $69^{\circ} 29.9^{\prime}$ & $151^{\circ} 29.4^{\prime}$ & $61 / 200$ & Colville Gp. & $\begin{array}{l}\text { Cenomanian to } \\
\text { Maastrichtian }\end{array}$ & $\sim 65-97$ & Fair \\
\hline 88POS44A & $69^{\circ} 56.1^{\prime}$ & $151^{\circ} 35.8^{\prime}$ & $15 / 50$ & Colville Gp. & $\begin{array}{c}\text { Cenomanian to } \\
\text { Maastrichtian }\end{array}$ & $\sim 65-97$ & Excellent \\
\hline 88POS48A & $69^{\circ} 25.7^{\prime}$ & $151^{\circ} 36.3^{\prime}$ & $84 / 275$ & Colville Gp. & $\begin{array}{c}\text { Cenomanian to } \\
\text { Maastrichtian }\end{array}$ & $\sim 65-97$ & Excellent \\
\hline 88POS55A & $69^{\circ} 58.1^{\prime}$ & $151^{\circ} 44.8^{\prime}$ & $30 / 100$ & $\begin{array}{c}\text { Sagavanirktok } \\
\text { Fm. }\end{array}$ & $\begin{array}{l}\text { Upper Cret. to } \\
\text { Pliocene }\end{array}$ & $\sim 2-70$ & Excellent \\
\hline
\end{tabular}


Sample details and apatite yields for outcrop samples (continued).

\begin{tabular}{|c|c|c|c|c|c|c|c|}
\hline $\begin{array}{l}\text { Sample } \\
\text { number }\end{array}$ & Long. & Lat. & $\begin{array}{c}\text { Elevation } \\
\mathrm{m} / \mathrm{ft}\end{array}$ & Unit & $\begin{array}{l}\text { Stratigraphic C } \\
\text { subdivision } 1\end{array}$ & $\begin{array}{c}\text { Chronostratigraphic } \\
\operatorname{age}^{2}(\mathrm{Ma})\end{array}$ & $\begin{array}{c}\text { Apatite } \\
\text { yield }^{3}\end{array}$ \\
\hline $\begin{array}{l}\text { "Ice cut": } \\
\text { 88POS22A }\end{array}$ & $69^{\circ} 02.4^{\prime}$ & $148^{\circ} 52.5^{\prime}$ & $396 / 1,300$ & Nanushuk Gp. & $\begin{array}{l}\text { Albian to } \\
\text { Cenomanian }\end{array}$ & 90-112 & Excellent \\
\hline $\begin{array}{l}\text { Sagwon Bluff } \\
88 \text { POS24A }\end{array}$ & $69^{\circ} 18.8^{\prime}$ & $148^{\circ} 40.9^{\prime}$ & $225 / 740$ & $\begin{array}{l}\text { Sagavanirktok Fm } \\
\text { Sagwon Mbr. }\end{array}$ & $\begin{array}{l}\text { n. Paleocene } \\
\text { and Eocene }\end{array}$ & $\sim 35-65$ & Excellent \\
\hline $88 \mathrm{POS} 25 \mathrm{~A}$ & $69^{\circ} 23.2^{\prime}$ & $148^{\circ} 42.1^{\prime}$ & $220 / 720$ & $\begin{array}{l}\text { Sagavanirktok Fm } \\
\text { Sagwon Mbr. }\end{array}$ & $\begin{array}{l}\text { n. Paleocene } \\
\text { and Eocene }\end{array}$ & $\sim 35-65$ & Excellent \\
\hline 88POS26A & $69^{\circ} 26.2^{\prime}$ & $148^{\circ} 31.0^{\prime}$ & $183 / 600 \mathrm{~S}$ & $\begin{array}{l}\text { Sagavanirktok Fm } \\
\text { Sagwon Mbr. }\end{array}$ & $\begin{array}{l}\text { n. Paleocene } \\
\text { and Eocene }\end{array}$ & $\sim 35-65$ & Excellent \\
\hline $\begin{array}{l}\text { Cobblestone } \\
\text { 89POS119A }\end{array}$ & $\begin{array}{l}\text { reek: } \\
68^{\circ} 23.7^{\prime}\end{array}$ & $150^{\circ} 19.0^{\prime}$ & $994 / 3,260$ & Karen Creek ss. & Upper Triassic & $\sim 205-220$ & Very Good \\
\hline 89POS121A & $68^{\circ} 24.2^{\prime}$ & $150^{\circ} 19.2^{\prime}$ & $985 / 3,230$ & Okpikruak Fm. & $\begin{array}{l}\text { Valanginian to } \\
\text { Barremian }\end{array}$ & $\sim 124-140$ & Excellent \\
\hline 89POS122A & $68^{\circ} 24.5^{\prime}$ & $150^{\circ} 19.2^{\prime}$ & $1006 / 3,300$ & Okpikruak Fm. & $\begin{array}{l}\text { Valanginian to } \\
\text { Barremian }\end{array}$ & $\sim 124-140$ & Excellent \\
\hline 89POS125A & $68^{\circ} 25.3^{\prime}$ & $150^{\circ} 19.8^{\prime}$ & $977 / 3,210$ & Okpikruak Fm. & $\begin{array}{l}\text { Valanginian to } \\
\text { Barremian }\end{array}$ & $\sim 124-140$ & Excellent \\
\hline 89POS126A & $68^{\circ} 33.1^{\prime}$ & $150^{\circ} 22.7^{\prime}$ & $762 / 2,500$ & $\begin{array}{c}\text { Sandstone at } \\
\text { Cobblestone } \mathrm{Ck} .\end{array}$ & $\begin{array}{l}\text { Barremian } \\
\text { to Aptian }\end{array}$ & $\sim 112-132$ & Excellent \\
\hline 89POS127A & $68^{\circ} 31.3^{\prime}$ & $150^{\circ} 28.8^{\prime}$ & $793 / 2,600$ & $\begin{array}{c}\text { Sandstone at } \\
\text { Cobblestone } \mathrm{Ck} .\end{array}$ & $\begin{array}{l}\text { Barremian } \\
\text { to Aptian }\end{array}$ & $\sim 112-132$ & Excellent \\
\hline 89POS129A & $68^{\circ} 32.0^{\prime}$ & $150^{\circ} 23.8^{\prime}$ & $674 / 2,110$ & $\begin{array}{c}\text { Sandstone at } \\
\text { Cobblestone Ck. }\end{array}$ & $\begin{array}{l}\text { Barremian } \\
\text { to Aptian }\end{array}$ & $\sim 112-132$ & Excellent \\
\hline $\begin{array}{l}\text { Northern Foo } \\
\text { 88POS51A }\end{array}$ & $\begin{array}{l}\text { hills: } \\
69^{\circ} 09.3^{\prime}\end{array}$ & $151^{\circ} 00.3^{\prime}$ & $198 / 650$ & Colville Gp. & $\begin{array}{l}\text { Cenomanian to } \\
\text { Maastrichtian }\end{array}$ & $\sim 65-97$ & Excellent \\
\hline 88POS52B & $69^{\circ} 02.7^{\prime}$ & $150^{\circ} 53.0^{\prime}$ & $244 / 800$ & Colville Gp. & $\begin{array}{l}\text { Cenomanian to } \\
\text { Maastrichtian }\end{array}$ & $\sim 65-97$ & Excellent \\
\hline 88POS53B & $69^{\circ} 04.3^{\prime}$ & $150^{\circ} 50.1^{\prime}$ & $238 / 780$ & Colville Gp. & $\begin{array}{l}\text { Cenomanian to } \\
\text { Maastrichtian }\end{array}$ & $\sim 65-97$ & Excellent \\
\hline 88POS53C & $69^{\circ} 04.3^{\prime}$ & $150^{\circ} 50.1^{\prime}$ & $238 / 780$ & Colville Gp. & $\begin{array}{l}\text { Cenomanian to } \\
\text { Maastrichtian }\end{array}$ & $\sim 65-97$ & Excellent \\
\hline 88POS56A & $68^{\circ} 57.3^{\prime}$ & $151^{\circ} 12.7^{\prime}$ & $274 / 900$ & Nanushuk Gp. & $\begin{array}{l}\text { Albian to } \\
\text { Cenomanian }\end{array}$ & $\sim 90-112$ & Excellent \\
\hline 88POS57A & $68^{\circ} 44.1^{\prime}$ & $152^{\circ} 17.3^{\prime}$ & $616 / 2,020$ & Nanushuk Gp. & $\begin{array}{c}\text { Albian to } \\
\text { Cenomanian }\end{array}$ & 90-112 & Excellent \\
\hline 88POS58A & $68^{\circ} 43.9^{\prime}$ & $152^{\circ} 17.8^{\prime}$ & $351 / 1,150$ & Torok Fm. I & $\begin{array}{l}\text { Upper Albian to } \\
\text { ower Cenomanian }\end{array}$ & 90-112 & Very Good \\
\hline 89KIL1-C & $68^{\circ} 53.7^{\prime}$ & $153^{\circ} 24.9^{\prime}$ & $311 / 1,020$ & Nanushuk Gp. & $\begin{array}{c}\text { Albian to } \\
\text { Cenomanian }\end{array}$ & 90-112 & Poor \\
\hline 89KIL2-B & $68^{\circ} 49.2^{\prime}$ & $152^{\circ} 44.0^{\prime}$ & $451 / 1,480$ & Nanushuk Gp. & $\begin{array}{l}\text { Albian to } \\
\text { Cenomanian }\end{array}$ & 90-112 & Good \\
\hline 89KIL3-B & $68^{\circ} 46.1^{\prime}$ & $152^{\circ} 20.9^{\prime}$ & $533 / 1,750$ & Nanushuk Gp. & $\begin{array}{l}\text { Albian to } \\
\text { Cenomanian }\end{array}$ & 90-112 & Excellent \\
\hline 89KIL4-B & $68^{\circ} 45.8^{\prime}$ & $151^{\circ} 51.0^{\prime}$ & $384 / 1,260$ & Nanushuk Gp. & $\begin{array}{l}\text { Albian to } \\
\text { Cenomanian }\end{array}$ & $\sim 90-112$ & Excellent \\
\hline 89KIL5-B & $68^{\circ} 49.8^{\prime}$ & $151^{\circ} 05.7^{\prime}$ & $677 / 2,220$ & Nanushuk Gp. & $\begin{array}{l}\text { Albian to } \\
\text { Cenomanian }\end{array}$ & 90-112 & Excellent \\
\hline 89KIL6-C & $68^{\circ} 42.4^{\prime}$ & $150^{\circ} 22.5^{\prime}$ & $625 / 2,050$ & Nanushuk Gp. & $\begin{array}{c}\text { Albian to } \\
\text { Cenomanian } \\
\end{array}$ & 90-112 & Excellent \\
\hline
\end{tabular}


Sample details and apatite yields for well samples.

[Samples listed by increasing depth. BHT, bottom-hole temperature; TD, total depth.]

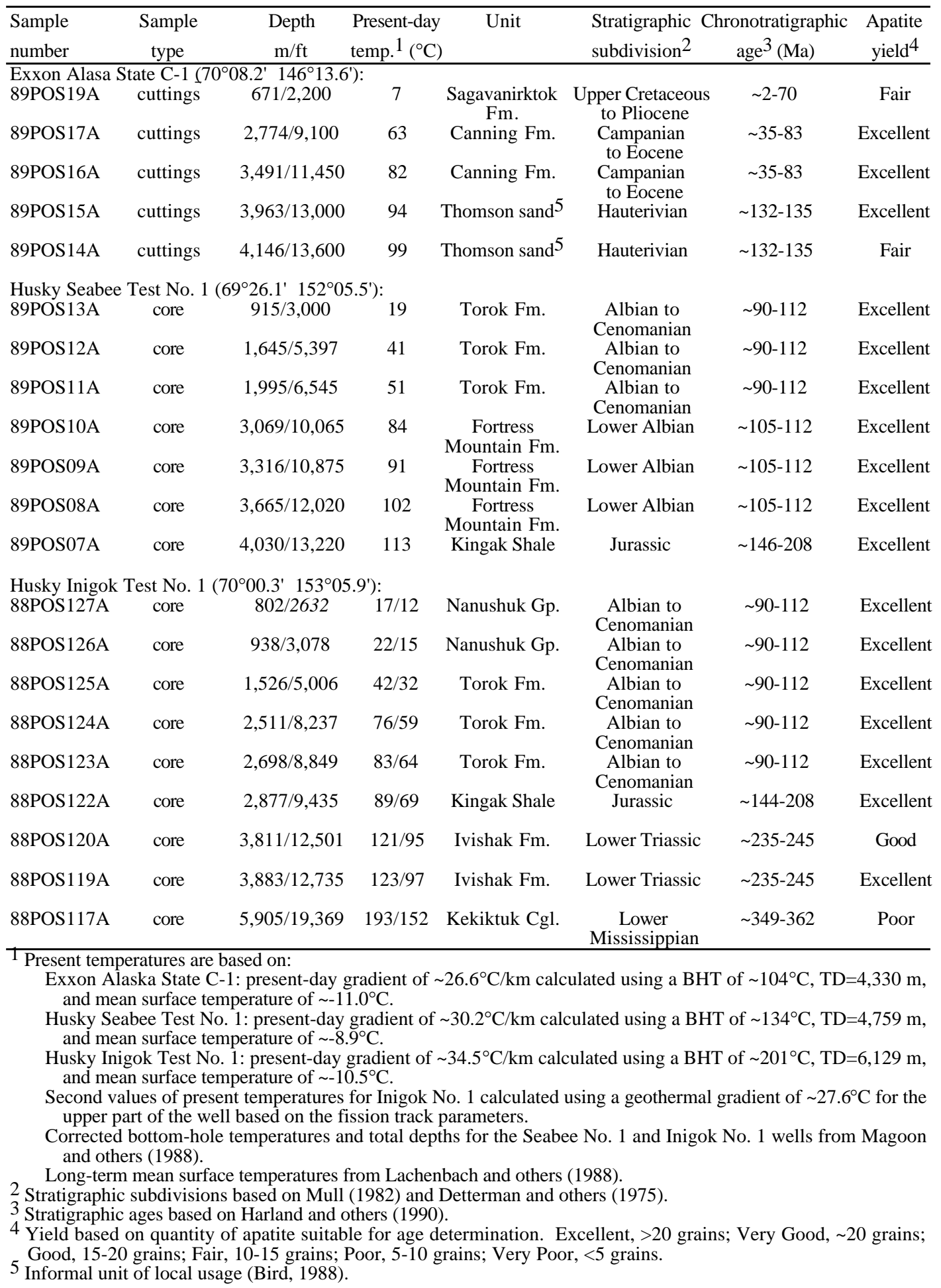


APPENDIX B. ANALYTICAL RESULTS

Apatite-fission-track analytical results for outcrop samples.

[Data listed by increasing depth. Parenthesis show number of tracks counted. Pct, percent. Standard and induced track densities measured on mica external detectors $\left(\mathrm{g}=0.5\right.$ ), and fossil track densities on internal mineral surfaces. $\left.{ }^{*}\right)$ Mean age, used where pooled data fail $\chi^{2}$ test at 5 percent. Errors quoted at $\pm 1 \sigma$. Ages for samples calculated using $\zeta=352.7$ for dosimeter glass SRM612 (Hurford and Green, 1983)]

\begin{tabular}{|c|c|c|c|c|c|c|c|c|c|}
\hline $\begin{array}{l}\text { Sample } \\
\text { number }\end{array}$ & $\begin{array}{c}\text { Number } \\
\text { of } \\
\text { grains }\end{array}$ & $\begin{array}{c}\text { Standard } \\
\text { track } \\
\text { density } \\
\left(\times 10^{6} \mathrm{~cm}^{-2}\right) \\
\end{array}$ & $\begin{array}{c}\text { Fossil } \\
\text { track } \\
\text { density } \\
\left(\times 10^{5} \mathrm{~cm}^{-2}\right) \\
\end{array}$ & $\begin{array}{c}\text { Induced } \\
\text { track } \\
\text { density } \\
\left(\times 10^{6} \mathrm{~cm}^{-2}\right) \\
\end{array}$ & $\begin{array}{c}\text { Chi } \\
\text { square } \\
\text { probability } \\
(\text { Pct }) \\
\end{array}$ & $\begin{array}{c}\text { Fission- } \\
\text { track } \\
\text { age } \\
(\mathrm{Ma}) \\
\end{array}$ & $\begin{array}{c}\text { Uranium } \\
\text { (ppm) }\end{array}$ & $\begin{array}{c}\text { Mean } \\
\text { track } \\
\text { length } \\
(\mu \mathrm{m}) \\
\end{array}$ & $\begin{array}{c}\text { Standard } \\
\text { deviation } \\
(\mu \mathrm{m})\end{array}$ \\
\hline \multicolumn{10}{|c|}{ Atigun Syncline: } \\
\hline $89 \mathrm{POS} 102 \mathrm{~A}$ & 21 & $\begin{array}{c}1.334 \\
(2,098)\end{array}$ & $\begin{array}{l}1.861 \\
(168)\end{array}$ & $\begin{array}{r}75.67 \\
(681)\end{array}$ & 0.9 & $\begin{array}{l}57.8 \pm 5.1 \\
67.1 \pm 8.3^{*}\end{array}$ & 7.4 & $\begin{array}{c}13.94 \pm 0.18 \\
(102)\end{array}$ & 1.78 \\
\hline 89POS103A & 20 & $\begin{array}{c}1.334 \\
(2,098)\end{array}$ & $\begin{array}{l}1.913 \\
(118)\end{array}$ & $\begin{array}{l}73.75 \\
(455)\end{array}$ & 12.1 & $60.7 \pm 6.4$ & 7.2 & $\begin{array}{c}13.21 \pm 0.24 \\
(106)\end{array}$ & 2.46 \\
\hline 89POS104A & 22 & $\begin{array}{l}1.334 \\
(2,098)\end{array}$ & $\begin{array}{l}4.659 \\
(398)\end{array}$ & $\begin{array}{c}1.969 \\
(1,682)\end{array}$ & 0.1 & $\begin{array}{c}55.4 \pm 3.4 \\
44.3 \pm 4.7^{*}\end{array}$ & 19.3 & $\begin{array}{c}13.63 \pm 0.28 \\
(56)\end{array}$ & 2.09 \\
\hline 89POS105A & 21 & $\begin{array}{l}1.334 \\
(2,098)\end{array}$ & $\begin{array}{l}4.824 \\
(329)\end{array}$ & $\begin{array}{c}2.224 \\
(1,517)\end{array}$ & 0.0 & $\begin{array}{c}50.8 \pm 3.3 \\
52.8 \pm 7.8^{*}\end{array}$ & 21.8 & $\begin{array}{c}13.98 \pm 0.32 \\
(22)\end{array}$ & 1.48 \\
\hline 89POS106A & 20 & $\begin{array}{c}1.334 \\
(2,098)\end{array}$ & $\begin{array}{l}4.103 \\
(304)\end{array}$ & $\begin{array}{c}2.311 \\
(1,712)\end{array}$ & 0.2 & $\begin{array}{c}41.6 \pm 2.8 \\
52.9 \pm 7.9^{*}\end{array}$ & 22.7 & $\begin{array}{c}13.72 \pm 0.20 \\
(100)\end{array}$ & 2.00 \\
\hline 89POS107A & 20 & $\begin{array}{c}1.334 \\
(2,098)\end{array}$ & $\begin{array}{l}5.103 \\
(379)\end{array}$ & $\begin{array}{l}2.107 \\
(1,565)\end{array}$ & 20.6 & $56.7 \pm 3.5$ & 20.7 & $\begin{array}{c}13.12 \pm 0.26 \\
(71)\end{array}$ & 2.23 \\
\hline 89POS108A & 20 & $\begin{array}{l}1.334 \\
(2,098)\end{array}$ & $\begin{array}{l}7.302 \\
(412)\end{array}$ & $\begin{array}{c}2.866 \\
(1,617)\end{array}$ & 0.0 & $\begin{array}{c}59.7 \pm 3.6 \\
61.8 \pm 14.0^{*}\end{array}$ & 28.1 & $\begin{array}{c}12.31 \pm 0.49 \\
(29)\end{array}$ & 2.63 \\
\hline 89POS109A & 15 & $\begin{array}{l}1.334 \\
(2,098)\end{array}$ & $\begin{array}{l}4.491 \\
(210)\end{array}$ & $\begin{array}{l}1.786 \\
(835)\end{array}$ & 0.0 & $\begin{array}{c}58.9 \pm 4.8 \\
50.9 \pm 19.5^{*}\end{array}$ & 17.5 & $\begin{array}{c}13.93 \pm 0.24 \\
(33)\end{array}$ & 1.37 \\
\hline 89POS110A & 17 & $\begin{array}{c}1.334 \\
(2,098)\end{array}$ & $\begin{array}{l}7.964 \\
(266)\end{array}$ & $\begin{array}{c}3.701 \\
(1,236)\end{array}$ & 0.0 & $\begin{array}{c}50.4 \pm 3.6 \\
72.8 \pm 17.1^{*}\end{array}$ & 36.3 & $\begin{array}{c}14.04 \pm 0.24 \\
(38)\end{array}$ & 1.50 \\
\hline 89POS111A & 20 & $\begin{array}{l}1.290 \\
(2,030)\end{array}$ & $\begin{array}{l}2.771 \\
(263)\end{array}$ & $\begin{array}{l}1.586 \\
(1,505)\end{array}$ & 0.1 & $\begin{array}{c}39.6 \pm 2.8 \\
51.0 \pm 6.1^{*}\end{array}$ & 16.1 & $14.01 \pm 0.26$ & 2.06 \\
\hline 89POS118A & 20 & $\begin{array}{l}1.290 \\
(2,030)\end{array}$ & $\begin{array}{l}5.272 \\
(506)\end{array}$ & $\begin{array}{c}2.062 \\
(1,979)\end{array}$ & 0.0 & $\begin{array}{c}57.9 \pm 3.2 \\
57.0 \pm 5.3^{*}\end{array}$ & 20.9 & $\begin{array}{c}14.23 \pm 0.32 \\
(44)\end{array}$ & 2.09 \\
\hline \multicolumn{10}{|c|}{ Marmot Syncline: } \\
\hline 88POS30B & 20 & $\begin{array}{c}2.323 \\
(5,105)\end{array}$ & $\begin{array}{l}0.296 \\
(102)\end{array}$ & $\begin{array}{l}2.461 \\
(848)\end{array}$ & 45.5 & $49.1 \pm 5.2$ & 13.9 & $\begin{array}{c}14.30 \pm 0.17 \\
(61)\end{array}$ & 1.33 \\
\hline $88 \mathrm{POS} 31 \mathrm{~A}$ & 20 & $\begin{array}{l}2.323 \\
(5,105)\end{array}$ & $\begin{array}{c}0.161 \\
(58)\end{array}$ & $\begin{array}{l}1.121 \\
(404)\end{array}$ & 82.7 & $58.5 \pm 8.3$ & 19.1 & $\begin{array}{c}14.17 \pm 0.15 \\
(102)\end{array}$ & 1.52 \\
\hline $88 \mathrm{POS} 32 \mathrm{~A}$ & 20 & $\begin{array}{l}2.323 \\
(5,105)\end{array}$ & $\begin{array}{c}0.192 \\
(67)\end{array}$ & $\begin{array}{l}1.381 \\
(483)\end{array}$ & 83.6 & $56.6 \pm 7.4$ & 7.8 & $\begin{array}{c}13.99 \pm 0.30 \\
(29)\end{array}$ & 1.63 \\
\hline $88 \mathrm{POS} 33 \mathrm{~A}$ & 20 & $\begin{array}{c}2.323 \\
(5,105)\end{array}$ & $\begin{array}{c}0.270 \\
(76)\end{array}$ & $\begin{array}{l}2.663 \\
(749)\end{array}$ & 83.1 & $41.4 \pm 5.0$ & 15.0 & $\begin{array}{c}13.69 \pm 0.38 \\
(30)\end{array}$ & 2.10 \\
\hline $88 \mathrm{POS} 34 \mathrm{~A}$ & 20 & $\begin{array}{l}2.323 \\
(5,105)\end{array}$ & $\begin{array}{l}0.287 \\
(103)\end{array}$ & $\begin{array}{l}2.507 \\
(899)\end{array}$ & 87.2 & $46.8 \pm 4.9$ & 14.1 & $13.68 \pm 0.25$ & 1.79 \\
\hline 89POS96A & 20 & $\begin{array}{l}1.334 \\
(2,098)\end{array}$ & $\begin{array}{l}0.237 \\
(161)\end{array}$ & $\begin{array}{l}1.013 \\
(687)\end{array}$ & 40.2 & $54.9 \pm 5.0$ & 9.9 & $\begin{array}{c}14.14 \pm 0.17 \\
(101)\end{array}$ & 1.71 \\
\hline 89POS97A & 20 & $\begin{array}{l}1.334 \\
(2,098)\end{array}$ & $\begin{array}{l}0.200 \\
(141)\end{array}$ & $\begin{array}{l}0.993 \\
(701)\end{array}$ & 79.4 & $47.1 \pm 4.5$ & 9.8 & $\begin{array}{c}13.71 \pm 0.18 \\
(100)\end{array}$ & 1.84 \\
\hline 89POS98A & 20 & $\begin{array}{l}1.334 \\
(2,098)\end{array}$ & $\begin{array}{l}0.574 \\
(181)\end{array}$ & $\begin{array}{l}1.578 \\
(498)\end{array}$ & 0.0 & $\begin{array}{c}84.9 \pm 7.7 \\
68.7 \pm 12.3^{*}\end{array}$ & 15.5 & $\begin{array}{c}13.14 \pm 0.47 \\
\text { (12) }\end{array}$ & 1.62 \\
\hline 89POS99A & 20 & $\begin{array}{l}1.334 \\
(2,098)\end{array}$ & $\begin{array}{l}0.441 \\
(304)\end{array}$ & $\begin{array}{c}2.306 \\
(1,589)\end{array}$ & 10.4 & $44.8 \pm 3.0$ & 22.6 & $\begin{array}{c}13.73 \pm 0.25 \\
(81)\end{array}$ & 2.25 \\
\hline $\begin{array}{l}\text { "Ice cut": } \\
\text { 88POS22A }\end{array}$ & 25 & $\begin{array}{c}2.440 \\
(5,341)\end{array}$ & $\begin{array}{l}0.122 \\
(122)\end{array}$ & $\begin{array}{c}1.179 \\
(1,178)\end{array}$ & 63.7 & $44.4 \pm 4.3$ & 6.3 & $14.20 \pm 0.36$ & 2.30 \\
\hline \multicolumn{10}{|c|}{ Colville River (upper group): } \\
\hline 88POS37A & 20 & $\begin{array}{c}2.720 \\
(5,975)\end{array}$ & $\begin{array}{l}0.802 \\
(289)\end{array}$ & $\begin{array}{c}4.046 \\
(1,458)\end{array}$ & 42.1 & $94.4 \pm 6.3$ & 19.5 & $\begin{array}{c}13.98 \pm 0.23 \\
(22)\end{array}$ & 1.09 \\
\hline $88 \mathrm{POS} 41 \mathrm{~A}$ & 11 & $\begin{array}{l}2.720 \\
(5,975)\end{array}$ & $\begin{array}{l}0.664 \\
(140)\end{array}$ & $\begin{array}{l}2.773 \\
(585)\end{array}$ & 25.3 & $113.8 \pm 10.9$ & 13.4 & $\begin{array}{c}14.05 \pm 0.23 \\
(13)\end{array}$ & 0.84 \\
\hline $88 \mathrm{POS} 44 \mathrm{~A}$ & 20 & $\begin{array}{l}2.720 \\
(5,975)\end{array}$ & $\begin{array}{l}0.881 \\
(350)\end{array}$ & $\begin{array}{c}3.582 \\
(1,423)\end{array}$ & 4.8 & $\begin{array}{c}116.9 \pm 7.3 \\
140.0 \pm 16.9 *\end{array}$ & 17.3 & $\begin{array}{c}14.19 \pm 0.09 \\
(101)\end{array}$ & 0.89 \\
\hline $88 \mathrm{POS} 48 \mathrm{~A}$ & 20 & $\begin{array}{c}2.760 \\
(6,058)\end{array}$ & $\begin{array}{l}0.518 \\
(281)\end{array}$ & $\begin{array}{c}3.439 \\
(1,865)\end{array}$ & 2.2 & $\begin{array}{c}72.9 \pm 4.8 \\
78.6 \pm 9.4^{*}\end{array}$ & 16.3 & $\begin{array}{c}14.52 \pm 0.09 \\
(101)\end{array}$ & 0.91 \\
\hline $88 \mathrm{POS} 55 \mathrm{~A}$ & 20 & $\begin{array}{c}2.427 \\
(5,333)\end{array}$ & $\begin{array}{l}0.210 \\
(221)\end{array}$ & $\begin{array}{c}0.981 \\
(1,032)\end{array}$ & 95.6 & $91.0 \pm 6.9$ & 5.3 & $\begin{array}{c}14.86 \pm 0.10 \\
(101)\end{array}$ & 0.96 \\
\hline
\end{tabular}


Apatite-fission-track analytical results for outcrop samples (continued).

\begin{tabular}{|c|c|c|c|c|c|c|c|c|c|}
\hline $\begin{array}{l}\text { Sample } \\
\text { number }\end{array}$ & $\begin{array}{c}\text { Number } \\
\text { of } \\
\text { grains }\end{array}$ & $\begin{array}{c}\text { Standard } \\
\text { track } \\
\text { density } \\
\left(\times 10^{6} \mathrm{~cm}^{-2}\right) \\
\end{array}$ & $\begin{array}{c}\text { Fossil } \\
\text { track } \\
\text { density } \\
\left(\times 10^{5} \mathrm{~cm}^{-2}\right) \\
\end{array}$ & $\begin{array}{c}\text { Induced } \\
\text { track } \\
\text { density } \\
\left(\times 10^{6} \mathrm{~cm}^{-2}\right) \\
\end{array}$ & $\begin{array}{c}\text { Chi } \\
\text { square } \\
\text { probability } \\
\text { (Pct) }\end{array}$ & $\begin{array}{c}\text { Fission- } \\
\text { track } \\
\text { age } \\
\text { (Ma) }\end{array}$ & $\begin{array}{c}\text { Uranium } \\
\text { (ppm) }\end{array}$ & $\begin{array}{c}\text { Mean } \\
\text { track } \\
\text { length } \\
(\mu \mathrm{m}) \\
\end{array}$ & $\begin{array}{c}\text { Standard } \\
\text { deviation } \\
(\mu \mathrm{m})\end{array}$ \\
\hline \multicolumn{10}{|c|}{ Sagwon Bluffs: } \\
\hline 88POS24A & 25 & $\begin{array}{c}2.440 \\
(5,341)\end{array}$ & $\begin{array}{r}0.417 \\
(322)\end{array}$ & $\begin{array}{c}1.499 \\
(1,158)\end{array}$ & 0.0 & $\begin{array}{l}118.6 \pm 7.8 \\
74.1 \pm 19.2 *\end{array}$ & 8.0 & $\begin{array}{c}14.23 \pm 0.13 \\
(82)\end{array}$ & 1.16 \\
\hline $88 \mathrm{POS} 25 \mathrm{~A}$ & 25 & $\begin{array}{l}2.440 \\
(5,341)\end{array}$ & $\begin{array}{l}0.327 \\
(222)\end{array}$ & $\begin{array}{l}1.487 \\
(1,010)\end{array}$ & 0.3 & $\begin{array}{c}93.9 \pm 7.2 \\
71.3 \pm 14.1 *\end{array}$ & 8.0 & $\begin{array}{c}14.17 \pm 0.09 \\
(102)\end{array}$ & 0.96 \\
\hline $88 \mathrm{POS} 26 \mathrm{~A}$ & 25 & $\begin{array}{c}2.440 \\
(5,341)\end{array}$ & $\begin{array}{l}0.660 \\
(445)\end{array}$ & $\begin{array}{c}2.888 \\
(1,947)\end{array}$ & 0.0 & $\begin{array}{c}97.6 \pm 5.4 \\
72.6 \pm 15.1 *\end{array}$ & 15.5 & $\begin{array}{c}14.05 \pm 0.16 \\
(70)\end{array}$ & 1.35 \\
\hline \multicolumn{10}{|c|}{ Cobblestone Creek: } \\
\hline 89POS119A & 20 & $\begin{array}{c}1.290 \\
(2,030)\end{array}$ & $\begin{array}{c}3.335 \\
(85)\end{array}$ & $\begin{array}{l}1.844 \\
(470)\end{array}$ & 79.4 & $41.0 \pm 4.9$ & 18.7 & $14.89 \pm 1.10$ & 1.90 \\
\hline 89POS121A & 20 & $\begin{array}{l}1.290 \\
(2,030)\end{array}$ & $\begin{array}{l}0.109 \\
(462)\end{array}$ & $\begin{array}{l}1.683 \\
(716)\end{array}$ & 0.0 & $\begin{array}{c}145.1 \pm 9.4 \\
122.2 \pm 13.6^{*}\end{array}$ & * 17.1 & $\begin{array}{c}11.91 \pm 0.54 \\
(24)\end{array}$ & 2.67 \\
\hline $89 \mathrm{POS} 122 \mathrm{~A}$ & 21 & $\begin{array}{l}1.290 \\
(2,030)\end{array}$ & $\begin{array}{l}5.240 \\
(368)\end{array}$ & $\begin{array}{l}1.847 \\
(1,297)\end{array}$ & 0.0 & $\begin{array}{c}64.2 \pm 4.1 \\
81.7 \pm 19.1 *\end{array}$ & 18.8 & $14.00 \pm 0.18$ & 1.53 \\
\hline 89POS125A & 21 & $\begin{array}{l}1.290 \\
(2,030)\end{array}$ & $\begin{array}{l}6.159 \\
(367)\end{array}$ & $\begin{array}{c}2.109 \\
(1,257)\end{array}$ & 0.1 & $\begin{array}{c}66.1 \pm 4.2 \\
92.1 \pm 15.4^{*}\end{array}$ & 21.4 & $\begin{array}{c}13.48 \pm 0.29 \\
(68)\end{array}$ & 2.40 \\
\hline 89POS126A & 20 & $\begin{array}{l}1.290 \\
(2,030)\end{array}$ & $\begin{array}{l}6.852 \\
(533)\end{array}$ & $\begin{array}{c}2.940 \\
(2,287)\end{array}$ & 18.8 & $52.8 \pm 2.9$ & 29.9 & $\begin{array}{c}13.68 \pm 0.24 \\
(102)\end{array}$ & 2.44 \\
\hline 89POS127A & 20 & $\begin{array}{l}1.290 \\
(2,030)\end{array}$ & $\begin{array}{l}5.310 \\
(392)\end{array}$ & $\begin{array}{c}2.414 \\
(1,782)\end{array}$ & 76.3 & $49.8 \pm 3.0$ & 24.5 & $\begin{array}{c}13.53 \pm 0.21 \\
(101)\end{array}$ & 2.10 \\
\hline 89POS129A & 20 & $\begin{array}{l}1.290 \\
(2,030)\end{array}$ & $\begin{array}{l}8.096 \\
(555)\end{array}$ & $\begin{array}{c}3.924 \\
(2,690)\end{array}$ & 6.8 & $46.8 \pm 2.5$ & 39.8 & $\begin{array}{c}13.64 \pm 0.20 \\
(101)\end{array}$ & 2.02 \\
\hline \multicolumn{10}{|c|}{ Northern Foothills (lower group): } \\
\hline 88POS56A & 20 & $\begin{array}{c}2.760 \\
(6,058)\end{array}$ & $\begin{array}{l}0.505 \\
(142)\end{array}$ & $\begin{array}{c}3.588 \\
(1,009)\end{array}$ & 90.9 & $68.1 \pm 6.2$ & 17.0 & $\begin{array}{c}13.30 \pm 0.68 \\
(14)\end{array}$ & 2.54 \\
\hline 88POS57A & 20 & $\begin{array}{c}2.427 \\
(5,333)\end{array}$ & $\begin{array}{l}0.233 \\
(136)\end{array}$ & $\begin{array}{l}1.711 \\
(997)\end{array}$ & 100.0 & $58.1 \pm 5.4$ & 9.2 & $\begin{array}{c}13.88 \pm 0.10 \\
(100)\end{array}$ & 0.99 \\
\hline 88POS58A & 20 & $\begin{array}{c}2.427 \\
(5,333)\end{array}$ & $\begin{array}{l}0.205 \\
(127)\end{array}$ & $\begin{array}{l}1.529 \\
(949)\end{array}$ & 100.0 & $57.0 \pm 5.5$ & 8.3 & $\begin{array}{c}14.08 \pm 0.13 \\
(56)\end{array}$ & 0.94 \\
\hline 89KIL1-C & 6 & $\begin{array}{c}1.314 \\
(5,630)\end{array}$ & $\begin{array}{c}0.387 \\
(80)\end{array}$ & $\begin{array}{l}1.598 \\
(330)\end{array}$ & 8.8 & $55.9 \pm 7.0$ & 15.9 & $13.89 \pm 0.09$ & 0.09 \\
\hline 89KIL2-B & 19 & $\begin{array}{l}1.176 \\
(2,791)\end{array}$ & $\begin{array}{l}0.466 \\
(207)\end{array}$ & $\begin{array}{l}1.726 \\
(766)\end{array}$ & 100.0 & $55.8 \pm 4.5$ & 19.2 & $\begin{array}{c}13.93 \pm 0.12 \\
(21)\end{array}$ & 1.03 \\
\hline 89KIL3-B & 25 & $\begin{array}{l}1.235 \\
(2,791)\end{array}$ & $\begin{array}{l}0.224 \\
(162)\end{array}$ & $\begin{array}{l}0.839 \\
(606)\end{array}$ & 100.0 & $58.0 \pm 5.3$ & 8.9 & $\begin{array}{c}13.85 \pm 0.17 \\
(41)\end{array}$ & 1.44 \\
\hline 89KIL4-B & 25 & $\begin{array}{l}1.224 \\
(2,791)\end{array}$ & $\begin{array}{l}0.190 \\
(126)\end{array}$ & $\begin{array}{l}0.719 \\
(476)\end{array}$ & 100.0 & $56.9 \pm 5.8$ & 7.7 & $\begin{array}{c}14.53 \pm 0.16 \\
(34)\end{array}$ & 1.40 \\
\hline 89KIL5-B & 25 & $\begin{array}{l}1.190 \\
(2,971)\end{array}$ & $\begin{array}{l}0.301 \\
(210)\end{array}$ & $\begin{array}{l}1.188 \\
(830)\end{array}$ & 87.5 & $52.9 \pm 4.2$ & 13.1 & $\begin{array}{c}14.17 \pm 0.10 \\
(56)\end{array}$ & 0.99 \\
\hline 89KIL6-C & 25 & $\begin{array}{c}1.246 \\
(2,791)\end{array}$ & $\begin{array}{l}0.167 \\
(133)\end{array}$ & $\begin{array}{l}0.626 \\
(497)\end{array}$ & 100.0 & $58.5 \pm 5.9$ & 6.6 & $14.33 \pm 0.19$ & 0.58 \\
\hline \multicolumn{10}{|c|}{ Northern Foothills (upper group): } \\
\hline 88POS51A & 20 & $\begin{array}{c}2.427 \\
(5,333)\end{array}$ & $\begin{array}{l}0.104 \\
(104)\end{array}$ & $\begin{array}{l}5.385 \\
(541)\end{array}$ & 81.9 & $81.8 \pm 8.9$ & 2.9 & $13.72 \pm 0.20$ & 1.54 \\
\hline $88 \mathrm{POS} 52 \mathrm{~B}$ & 20 & $\begin{array}{c}2.760 \\
(6,058)\end{array}$ & $\begin{array}{l}0.541 \\
(427)\end{array}$ & $\begin{array}{l}2.905 \\
(2,293)\end{array}$ & 72.6 & $90.0 \pm 5.0$ & 13.8 & $\begin{array}{c}14.77 \pm 0.11 \\
(100)\end{array}$ & 1.10 \\
\hline 88POS53B & 20 & $\begin{array}{l}2.760 \\
(6,058)\end{array}$ & $\begin{array}{l}0.566 \\
(181)\end{array}$ & $\begin{array}{l}2.210 \\
(707)\end{array}$ & 95.1 & $123.4 \pm 10.5$ & 10.5 & $\begin{array}{c}13.42 \pm 0.25 \\
(73)\end{array}$ & 2.09 \\
\hline $88 \mathrm{POS} 53 \mathrm{C}$ & 20 & $\begin{array}{l}2.427 \\
(5,333)\end{array}$ & $\begin{array}{l}0.624 \\
(281)\end{array}$ & $\begin{array}{c}3.036 \\
(1,366)\end{array}$ & 99.5 & $87.4 \pm 5.9$ & 16.4 & $\begin{array}{c}14.47 \pm 0.11 \\
(102)\end{array}$ & 1.09 \\
\hline $88 \mathrm{POS} 35 \mathrm{~A}$ & 20 & $\begin{array}{l}2.720 \\
(5,975)\end{array}$ & $\begin{array}{l}0.751 \\
(301)\end{array}$ & $\begin{array}{c}4.129 \\
(1,655)\end{array}$ & 80.2 & $86.7 \pm 5.6$ & 19.9 & $\begin{array}{c}13.77 \pm 0.12 \\
(102)\end{array}$ & 1.24 \\
\hline $88 \mathrm{POS} 36 \mathrm{~A}$ & 20 & $\begin{array}{c}2.720 \\
(5,975)\end{array}$ & $\begin{array}{l}0.720 \\
(252)\end{array}$ & $\begin{array}{c}3.642 \\
(1,274)\end{array}$ & 93.7 & $92.2 \pm 6.7$ & 17.5 & $\begin{array}{c}14.08 \pm 0.14 \\
(62)\end{array}$ & 1.08 \\
\hline
\end{tabular}


Apatite-fission-track analytical results for well samples.

[Data listed by increasing depth. Parenthesis show number of tracks counted. Pct, percent. Standard and induced track densities measured on mica external detectors $(\mathrm{g}=0.5)$, and fossil track densities on internal mineral surfaces. $(*)$ Mean age, used where pooled data fail $\mathrm{c} 2$ test at 5 percent. Errors quoted at $\pm 1 \mathrm{~s}$. Ages for samples calculated using $\mathrm{z}=352.7$ for dosimeter glass SRM612 (Hurford and Green, 1983)]

\begin{tabular}{|c|c|c|c|c|c|c|c|c|c|}
\hline $\begin{array}{l}\text { Sample } \\
\text { number }\end{array}$ & $\begin{array}{c}\text { Number } \\
\text { of } \\
\text { grains }\end{array}$ & $\begin{array}{c}\text { Standard } \\
\text { track } \\
\text { density } \\
\left(\times 10^{6} \mathrm{~cm}^{-2}\right) \\
\end{array}$ & $\begin{array}{c}\text { Fossil } \\
\text { track } \\
\text { density } \\
\left(\times 10^{5} \mathrm{~cm}^{-2}\right) \\
\end{array}$ & $\begin{array}{c}\text { Induced } \\
\text { track } \\
\text { density } \\
\left(\times 10^{6} \mathrm{~cm}^{-2}\right) \\
\end{array}$ & $\begin{array}{c}\text { Chi } \\
\text { square } \\
\text { probability } \\
\text { (Pct.) } \\
\end{array}$ & $\begin{array}{l}\text { Fission- } \\
\text { track } \\
\text { age } \\
\text { (Ma) } \\
\end{array}$ & $\begin{array}{c}\text { Uranium } \\
\text { (ppm) }\end{array}$ & $\begin{array}{c}\text { Mean } \\
\text { track } \\
\text { length } \\
(\mu \mathrm{m}) \\
\end{array}$ & $\begin{array}{c}\text { Standard } \\
\text { deviation } \\
(\mu \mathrm{m})\end{array}$ \\
\hline \multicolumn{10}{|c|}{ Exxon Alaska State C-1: } \\
\hline 89POS19A & 12 & $\begin{array}{c}1.218 \\
(2,741)\end{array}$ & $\begin{array}{l}8.478 \\
(190)\end{array}$ & $\begin{array}{l}1.963 \\
(440)\end{array}$ & 2.4 & $\begin{array}{c}92.1 \pm 8.3 \\
81.0 \pm 24.1^{*}\end{array}$ & 21.1 & $\begin{array}{c}12.14 \pm 0.47 \\
(31)\end{array}$ & 2.63 \\
\hline 89POS17A & 20 & $\begin{array}{c}1.218 \\
(2,741)\end{array}$ & $\begin{array}{l}5.993 \\
(226)\end{array}$ & $\begin{array}{l}1.843 \\
(695)\end{array}$ & 0.0 & $\begin{array}{c}69.5 \pm 5.6 \\
100.3 \pm 20.4^{*}\end{array}$ & 19.8 & $\begin{array}{c}12.27 \pm 0.64 \\
(21)\end{array}$ & 2.93 \\
\hline 89POS16A & 25 & $\begin{array}{c}1.218 \\
(2,741)\end{array}$ & $\begin{array}{l}2.657 \\
(138)\end{array}$ & $\begin{array}{l}98.79 \\
(513)\end{array}$ & 0.0 & $\begin{array}{c}57.5 \pm 5.7 \\
82.6 \pm 16.7^{*}\end{array}$ & 10.6 & $\begin{array}{c}9.93 \pm 0.28 \\
(41)\end{array}$ & 1.81 \\
\hline 89POS15A & 26 & $\begin{array}{c}1.225 \\
(2,756)\end{array}$ & $\begin{array}{l}2.694 \\
(144)\end{array}$ & $\begin{array}{l}1.085 \\
(580)\end{array}$ & 27.4 & $53.4 \pm 5.1$ & 11.6 & $\begin{array}{c}8.79 \pm 0.52 \\
\quad(26)\end{array}$ & 2.64 \\
\hline 89POS14A & 14 & $\begin{array}{c}1.225 \\
(2,756)\end{array}$ & $\begin{array}{c}46.69 \\
(5)\end{array}$ & $\begin{array}{c}89.64 \\
(96)\end{array}$ & 87.4 & $11.2 \pm 5.2$ & 9.6 & $\begin{array}{l}- \\
\text { (0) }\end{array}$ & - \\
\hline \multicolumn{10}{|c|}{ Husky Seabee Test No. 1: } \\
\hline 89POS13A & 25 & $\begin{array}{c}1.225 \\
(2,756)\end{array}$ & $\begin{array}{l}0.113 \\
(722)\end{array}$ & $\begin{array}{c}2.336 \\
(1,499)\end{array}$ & 1.1 & $\begin{array}{c}103.2 \pm 5.3 \\
102.3 \pm 8.8^{*}\end{array}$ & 25.0 & $\begin{array}{c}12.14 \pm 0.22 \\
(102)\end{array}$ & 2.26 \\
\hline $89 \mathrm{POS} 12 \mathrm{~A}$ & 25 & $\begin{array}{c}1.225 \\
(2,756)\end{array}$ & $\begin{array}{c}3.180 \\
(91)\end{array}$ & $\begin{array}{l}1.366 \\
(391)\end{array}$ & 54.9 & $50.1 \pm 5.9$ & 14.6 & $\begin{array}{c}11.51 \pm 0.36 \\
(53)\end{array}$ & 2.61 \\
\hline $89 \mathrm{POS} 11 \mathrm{~A}$ & 25 & $\begin{array}{c}1.225 \\
(2,756)\end{array}$ & $\begin{array}{c}2.560 \\
(50)\end{array}$ & $\begin{array}{l}1.887 \\
(287)\end{array}$ & 50.1 & $37.5 \pm 5.8$ & 15.7 & $\begin{array}{c}12.72 \pm 0.34 \\
(31)\end{array}$ & 1.89 \\
\hline 89POS10A & 26 & $\begin{array}{c}1.225 \\
(2,756)\end{array}$ & $\begin{array}{l}3.411 \\
(101)\end{array}$ & $\begin{array}{l}2.759 \\
(817)\end{array}$ & 40.6 & $26.6 \pm 2.9$ & 29.5 & $\begin{array}{c}10.38 \pm 0.38 \\
(40)\end{array}$ & 2.39 \\
\hline 89POS09A & 25 & $\begin{array}{c}1.225 \\
(2,756)\end{array}$ & $\begin{array}{c}91.58 \\
(30)\end{array}$ & $\begin{array}{l}88.83 \\
(291)\end{array}$ & 27.7 & $22.2 \pm 4.3$ & 9.5 & $\begin{array}{c}9.68 \pm 1.18 \\
\text { (8) }\end{array}$ & 3.33 \\
\hline 89POS08A & 25 & $\begin{array}{c}1.225 \\
(2,756)\end{array}$ & $\begin{array}{c}58.79 \\
(10)\end{array}$ & $\begin{array}{l}1.887 \\
(874)\end{array}$ & 78.6 & $6.7 \pm 2.2$ & 20.2 & $\begin{array}{c}10.14 \pm 0.43 \\
\text { (7) }\end{array}$ & 1.13 \\
\hline 89POS07A & 25 & $\begin{array}{c}1.225 \\
(2,756)\end{array}$ & $\begin{array}{c}81.82 \\
(50)\end{array}$ & $\begin{array}{l}1.430 \\
(874)\end{array}$ & 3.1 & $\begin{array}{c}12.3 \pm 1.8 \\
15.6 \pm 3.9^{*}\end{array}$ & 15.3 & $\begin{array}{c}9.63 \pm 0.37 \\
(15)\end{array}$ & 1.44 \\
\hline \multicolumn{10}{|c|}{ Husky Inigok Test No. 1: } \\
\hline 88POS127A & 20 & $\begin{array}{c}2.861 \\
(11,864)\end{array}$ & $\begin{array}{l}0.335 \\
(128)\end{array}$ & $\begin{array}{l}1.722 \\
(657)\end{array}$ & 74.1 & $97.6 \pm 9.5$ & 8.4 & $\begin{array}{c}13.38 \pm 0.17 \\
(102)\end{array}$ & 1.73 \\
\hline 88POS126A & 20 & $\begin{array}{c}2.829 \\
(11,864)\end{array}$ & $\begin{array}{l}0.220 \\
(102)\end{array}$ & $\begin{array}{l}1.117 \\
(518)\end{array}$ & 99.0 & $97.5 \pm 10.6$ & 5.5 & $\begin{array}{c}13.13 \pm 0.16 \\
(102)\end{array}$ & 1.63 \\
\hline $88 \mathrm{POS} 125 \mathrm{~A}$ & 20 & $\begin{array}{c}2.797 \\
(11,864)\end{array}$ & $\begin{array}{l}0.221 \\
(130)\end{array}$ & $\begin{array}{l}1.057 \\
(622)\end{array}$ & 99.5 & $102.3 \pm 9.9$ & 5.2 & $\begin{array}{c}12.87 \pm 0.22 \\
(105)\end{array}$ & 2.24 \\
\hline $88 \mathrm{POS} 124 \mathrm{~A}$ & 20 & $\begin{array}{c}2.789 \\
(11,864)\end{array}$ & $\begin{array}{c}0.200 \\
(71)\end{array}$ & $\begin{array}{l}2.490 \\
(884)\end{array}$ & 29.0 & $39.4 \pm 4.9$ & 12.2 & $\begin{array}{c}12.19 \pm 0.17 \\
\text { (77) }\end{array}$ & 1.52 \\
\hline 88POS123A & 20 & $\begin{array}{c}2.733 \\
(11,864)\end{array}$ & $\begin{array}{c}0.112 \\
(42)\end{array}$ & $\begin{array}{l}1.391 \\
(520)\end{array}$ & 94.6 & $38.8 \pm 6.2$ & 6.8 & $\begin{array}{c}11.30 \pm 0.21 \\
(60)\end{array}$ & 1.63 \\
\hline $88 \mathrm{POS} 122 \mathrm{~A}$ & 20 & $\begin{array}{c}2.701 \\
(11,864)\end{array}$ & $\begin{array}{c}0.449 \\
(81)\end{array}$ & $\begin{array}{l}4.293 \\
(775)\end{array}$ & 30.6 & $49.6 \pm 5.8$ & 21.1 & $\begin{array}{c}10.68 \pm 0.45 \\
\quad(27)\end{array}$ & 2.33 \\
\hline $88 \mathrm{POS} 120 \mathrm{~A}$ & 16 & $\begin{array}{c}2.637 \\
(11,864)\end{array}$ & $\begin{array}{c}0.039 \\
(7)\end{array}$ & $\begin{array}{l}1.538 \\
(279)\end{array}$ & 65.0 & $11.7 \pm 4.5$ & 7.5 & $\begin{array}{c}- \\
(0)\end{array}$ & - \\
\hline 88POS119A & 20 & $\begin{array}{c}2.605 \\
(11,864)\end{array}$ & $\begin{array}{c}0.040 \\
(9)\end{array}$ & $\begin{array}{l}1.391 \\
(313)\end{array}$ & 89.1 & $13.2 \pm 4.5$ & 6.8 & $\begin{array}{c}7.56 \pm 1.43 \\
\text { (6) }\end{array}$ & 3.50 \\
\hline 88POS117A & 6 & $\begin{array}{c}2.573 \\
(11,864) \\
\end{array}$ & $\begin{array}{c}0.014 \\
(1)\end{array}$ & $\begin{array}{l}1.930 \\
(142)\end{array}$ & 87.4 & $3.2 \pm 3.2$ & 9.5 & $\begin{array}{c}- \\
(0)\end{array}$ & - \\
\hline
\end{tabular}




\title{
THERMAL EVOLUTION OF SEDIMENTARY BASINS IN ALASKA
}

U.S. Geological Survey Bulletin 2142

\section{Thermotectonic Evolution of Suspect Terranes in the Kandik Region of East-Central Alaska}

\author{
By Michael B. Underwood ${ }^{1}$, David G. Howell ${ }^{2}$, Mark J. Johnsson ${ }^{3}$, and Mark J. Pawlewicz ${ }^{4}$
}

\section{CONTENTS}

Abstract

Introduction

Basic principles

Illite crystallinity

Vitrinite reflectance and paleotemperature ........

Estimates of depth and pressure

Methods

Sampling

Vitrinite reflectance

X-ray diffraction

Results and basic interpretations

Tatonduk belt

Kandik River terrane

Doyon No. 1 Well

Glenn Creek Fault anomaly

Step Mountains

Slaven Dome, Woodchopper Canyon, and

Tacoma Bluff terranes

Unit TKs

Discussion and modeling

Early Cretaceous burial depths and geothermal gradients

Heating, cooling, and uplift history

Modeling of Glenn Creek footwall anomaly ..... 101

Summary and conclusions ....................................... 105

Acknowledgments .................................................. 106

References cited .................................................. 106

\footnotetext{
${ }^{1}$ Department of Geological Sciences, University of Missouri, Columbia, MO 65211.

${ }^{2}$ U.S. Geological Survey, MS-902, 345 Middlefield Road, Menlo Park, CA 94025. 2899.

${ }^{3}$ Department of Geology, Bryn Mawr College, Bryn Mawr, PA 19010-

${ }^{4}$ U.S. Geological Survey, MS-940, Box 25046 Denver Federal Center, Lakewood, CO 80225.
}

\begin{abstract}
The Kandik region of east-central Alaska contains a diverse array of tectonostratigraphic domains. Genetic links among these domains are ambiguous if based on standard lithologic and biostratigraphic correlation. On the other hand, thermal-maturity data and pressure-temperature-time (P-T-t) reconstructions show that the geologic histories of these domains have been significantly different; some of the domains are almost certainly allochthonous.

The Tatonduk belt, located in the southeastern part of the study area, represents a Proterozoic through Triassic continental-margin succession of North American affinity; these strata experienced a relatively small amount of thrust-related dislocation and crustal shortening during the Cretaceous. Measurements of mean random vitrinite reflectance $\left(R_{m}\right)$ show that most parts of the Tatonduk belt were never heated above $150^{\circ} \mathrm{C}$. Farther to the northwest, across the Glenn Creek Fault Zone, the geology consists mostly of Jurassic and Lower Cretaceous deep-marine deposits of the Kandik River terrane. These strata display well-developed slaty cleavage, abundant quartz-carbonate veins, and the effects of lower greenschistfacies metamorphism. Paleotemperatures, based on $R_{m}$ values, were as high as $315^{\circ} \mathrm{C}$, and geothermal gradients at the time of peak heating were approximately 35 to $60^{\circ} \mathrm{C} / \mathrm{km}$. The western edge of the study area (Eureka suture zone) contains three suspect terranes-Woodchopper Canyon, Slaven Dome, and Tacoma Bluff terranes. These strata show the same effects of thermal overprinting as do rocks of the Kandik River terrane.

Peak heating within the Kandik River terrane evidently occurred during middle to late Albian time ( 105 Ma). The thermal overprint probably was caused by hydrothermal and (or) magmatic activity in a backarc-basin environment and was followed in rapid succession by displacement of terranes toward the southeast, emplacement of warm hanging-wall rocks along the Glenn Creek Fault Zone (a northeast-verging, younger-over-older thrust), rapid uplift, denudation, and Cenomanian to Campanian cooling through the $100^{\circ} \mathrm{C}$ isotherm. During roughly the same interval of early Late Creta-
\end{abstract}


ceous time, the first nonmarine deposits of geologic unit TKs were shed from the Kandik orogenic highlands, and postorogenic alluvial-fluvial sediments continued to accumulate into latest Eocene or Oligocene time. Coal rank within most of unit TKs is consistent with paleotemperatures of less than $75^{\circ} \mathrm{C}$, so the basal unconformity of unit TKs corresponds to a major break in thermal history.

Two anomalous regions near the Glenn Creek Fault add to the complexity of reconstructing the regional thermotectonic history. The Step Mountains, located to the northwest of the Tatonduk-Kandik River terrane boundary, contain Devonian(?) to Permian strata in the core of an antiformal structure. The terrane designation for these rocks is problematic. Levels of thermal maturity are lower than average for the Kandik River terrane but higher than average for the Tatonduk belt. Our favored interpretation calls for exposure of footwall strata (Tatonduk belt) in a window exhumed through a folded Glenn Creek Thrust Fault. The second anomaly is located to the southeast of the Glenn Creek Fault, where a restricted zone of elevated thermal maturity occurs within the Devonian Nation River Formation; this anomaly probably was caused by conductive heat transfer from the hanging wall into the Tatonduk footwall, with maximum temperatures reaching approximately $250^{\circ} \mathrm{C}$. Preservation of this thrust aureole demonstrates that the Kandik River terrane had not cooled completely prior to the initiation of the Albian thrusting event. Unless there had been pronounced horizontal gradients in heat flow at the time of this event, the contrasts in geothermal regimes across the Glenn Creek Fault Zone seem to require several hundred kilometers of rapid tectonic displacement toward the east. The thermal overprint may have occurred in a backarc environment associated with the Kobuk-Koyukuk subbasin of the Yukon-Koyukuk region of central Alaska.

\section{INTRODUCTION}

The Kandik region of east-central Alaska (fig. 1) contains a wide variety of geologic units that are either parautochthonous or allochthonous with respect to the North American continent (Brabb and Churkin, 1969; Foster, 1976; Payne and Allison, 1981; Howell and Wiley, 1987; Dover and Miyaoka, 1988). This part of Alaska has been described and interpreted within the conceptual framework of "suspect terranes" (Churkin and others, 1982; Coney and Jones, 1985; Howell and Wiley, 1987; Laughland and others, 1990; Howell and others, 1992). In general, those authors would argue that genetic links among coeval rock units must be proven rather than assumed; this is especially true if the units in question are separated by known faults. Fault contacts are commonplace in orogenic belts, and the distance of fault displacement usually remains uncertain; hence the designation "suspect." Several types of terranes have been defined, including stratigraphic, disrupted, metamorphic, and composite (Jones and others, 1983; Coney, 1989). Other geologists, in contrast, regard the Kandik region as a relatively straightforward continental-margin succession of North American affinity that simply has been shortened by thrust faulting (Dover, 1990a). Following this philosophy, coeval units composed of similar lithologies are assumed to be correlative (that is, the same formation) unless proven otherwise. However, when attempting to establish genetic links, or lack thereof, among rock units within orogenic belts, one must consider the total geologic history, including deformational and thermal events, not simply the original stratigraphic context.

As a matter of fact, a full spectrum exists in the clarity of geologic linkage among neighboring tectonostratigraphic domains. At one end of the spectrum are examples, such as the Wrangellia terrane, that lack any lithostratigraphic similarities with their neighbors (Jones and others, 1977). Semantic arguments arise, however, when allochthonous relations are not so clear (Dover, 1990b). The problem with applying hypotheses to these ambiguous situations is that some important types of geologic events may be unaccounted for, because they leave a cryptic signal that escapes detection during normal field mapping. As demonstrated elsewhere (Kohn and others, 1992; Wintsch and others, 1992), convincing evidence can be generated to support or refute allochthonous relations among suspect terranes through studies of pressure-temperature-time (P-T-t) pathways. Pronounced contrasts in P-T-t paths for adjacent rock units, irrespective of superficial similarities in lithology or stratal age, can occur only when there are fundamental differences in geologic history prior to juxtaposition of domains via fault dislocation.

A variety of terms have been used to name tectonostratigraphic domains of the Kandik region (for example, block, belt, terrane); this is largely because of uncertainties regarding relative and absolute distances of tectonic transport. During the course of our field and laboratory investigations, we recognized the following fundamental units: two regional-scale fault-bounded domains (herein referred to as the Tatonduk belt and the Kandik River terrane), three smaller suspect terranes (Woodchopper Canyon, Slaven Dome, and Takoma Bluff terranes), one anomalous structure of disputed affinity (Step Mountains anticline), and one synorogenic to postorogenic cover sequence (unit TKs of Brabb and Churkin, 1969). The definition of these domains is valid for descriptive purposes without any connotations regarding absolute distances of tectonic transport. At the same time, we believe that these "terrane" designations become justified whenever data show the rocks to be allochthonous in any geologic respect (including thermal) relative to the rifted edge of North America.

The most significant structural boundary in the study area is the Glenn Creek Fault Zone, which separates the Kandik River terrane from the Tatonduk belt (fig. 1). This younger-over-older fault was referred to as the Kandik Detachment Fault by Dover and Miyaoka (1988), and it is part of a complicated system of southeast-verging thrusts (Dover, 
1990a; Howell and others, 1992). We believe that this fault is crucial because it separates domains with contrasting thermotectonic histories and contrasting products of fluidrock interactions. We have not been able to trace the terrane boundary with certainty into Canada (see Norris, 1984, for regional-scale map). Analysis of a sparse suite of Mesozoic rocks sampled within Canada (mostly the Kathul Graywacke), however, indicates that the distinctions in thermal maturity between the two domains are reduced considerably toward the east (Underwood and others, 1989). Along the southern limit of the study area, the Kandik River terrane and the Tatonduk belt are separated from the Yukon-Tanana compos-

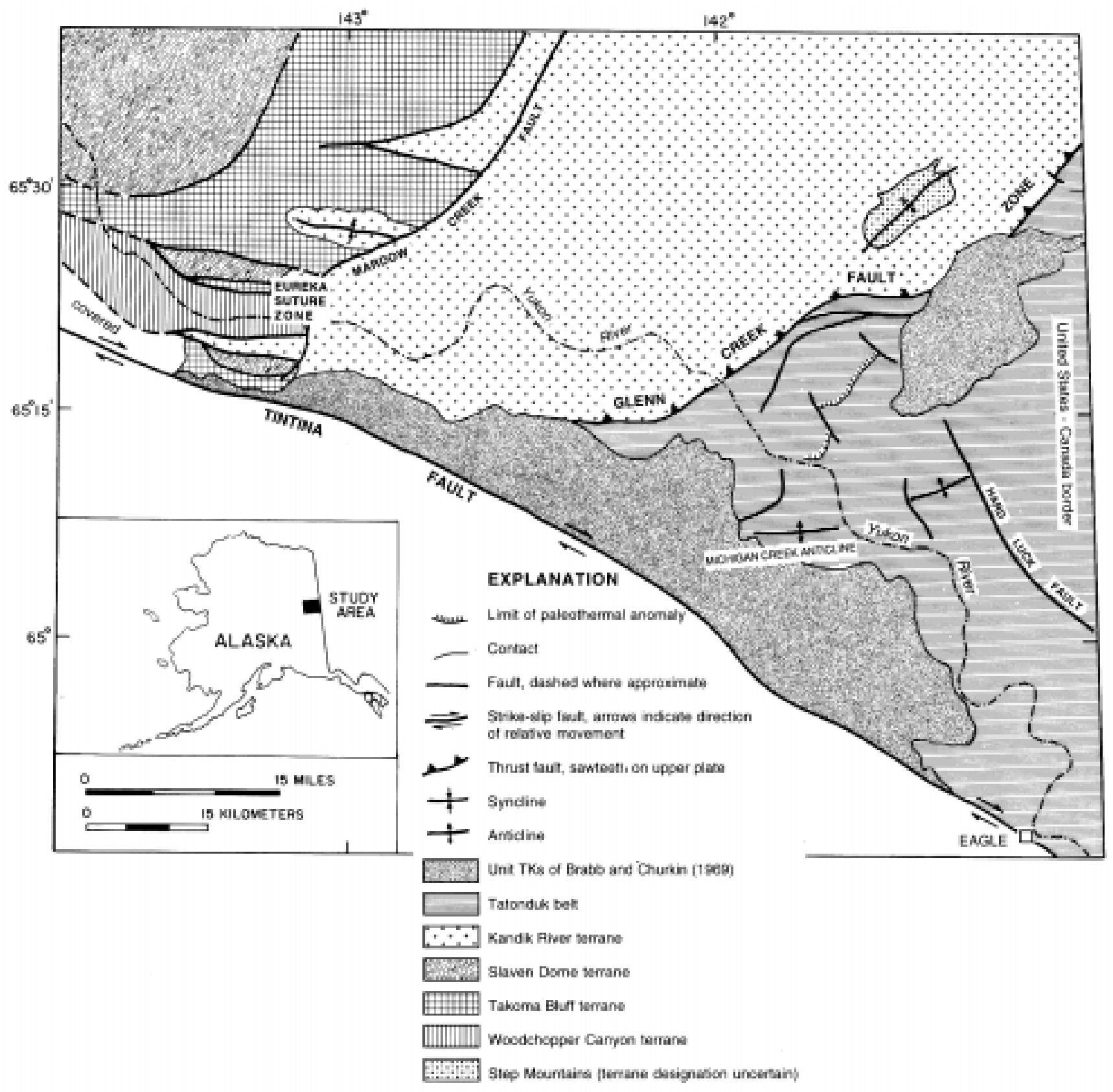

Figure 1. Geologic index map of east-central Alaska showing Kandik River terrane and Tatonduk belt. Tectonostratigraphic designation for rocks at Step Mountains is disputed. Hachured line southeast of Glenn Creek Fault represents detected limit of a footwall thermal aureole. Also shown are unit TKs of Brabb and Churkin (1969) and Woodchopper Canyon, Slaven Dome, and
Takoma Bluff terranes of Eureka suture zone (Churkin and others, 1982). Rocks southwest of Tintina Fault Zone are assigned to Yukon-Tanana composite terrane (Coney and Jones, 1985). Modified from Brabb and Churkin (1969) and Foster (1976). For relevant fossil control and alternative interpretations of structural geology, see Dover and Miyaoka (1988), Miyaoka (1990), and Dover (1992). 
ite terrane (as defined by Coney and Jones, 1985) by the Tintina Fault, which is a major right-lateral strike slip fault (fig. 1). To the north and west of the study area, the Tertiary and older rock units are largely covered by loess deposits of the Yukon Flats (Brabb and Churkin, 1969).

The Tatonduk belt (fig. 2) consists of a Middle Proterozoic to Lower Cambrian basement complex (Tindir Group) of basalt, carbonate rocks, diamictite, and shale (Young, 1982; Allison, 1988). These strata are overlain by a nearly complete Paleozoic succession of sedimentary rocks that record the rifting and progressive subsidence of the North American continental margin (Payne and Allison, 1981; Churkin and others, 1982; Howell and Wiley, 1987; Howell and others, 1992). For the purposes of our study, the most important unit within this passive-margin to foreland-basin succession is the Nation River Formation (Upper Devonian); this formation is composed of turbidites and related deposits that contain abundant terrigenous organic matter, which allows for accurate measurements of thermal maturity. The youngest strata within the Tatonduk belt are assigned to the lower part of the Glenn Shale, which ranges in age from Middle Triassic to Late Triassic (Dover and Miyaoka, 1988).

The Kandik River terrane (fig. 3) is composed mostly of deep-marine deposits of Mesozoic age (Churkin and others, 1982). The principal rock units within the Kandik River terrane consist of the upper part of the Glenn Shale (Jurassic and Lower Cretaceous) and the Lower Cretaceous Kandik Group (Keenan Quartzite, Biederman Argillite, and Kathul

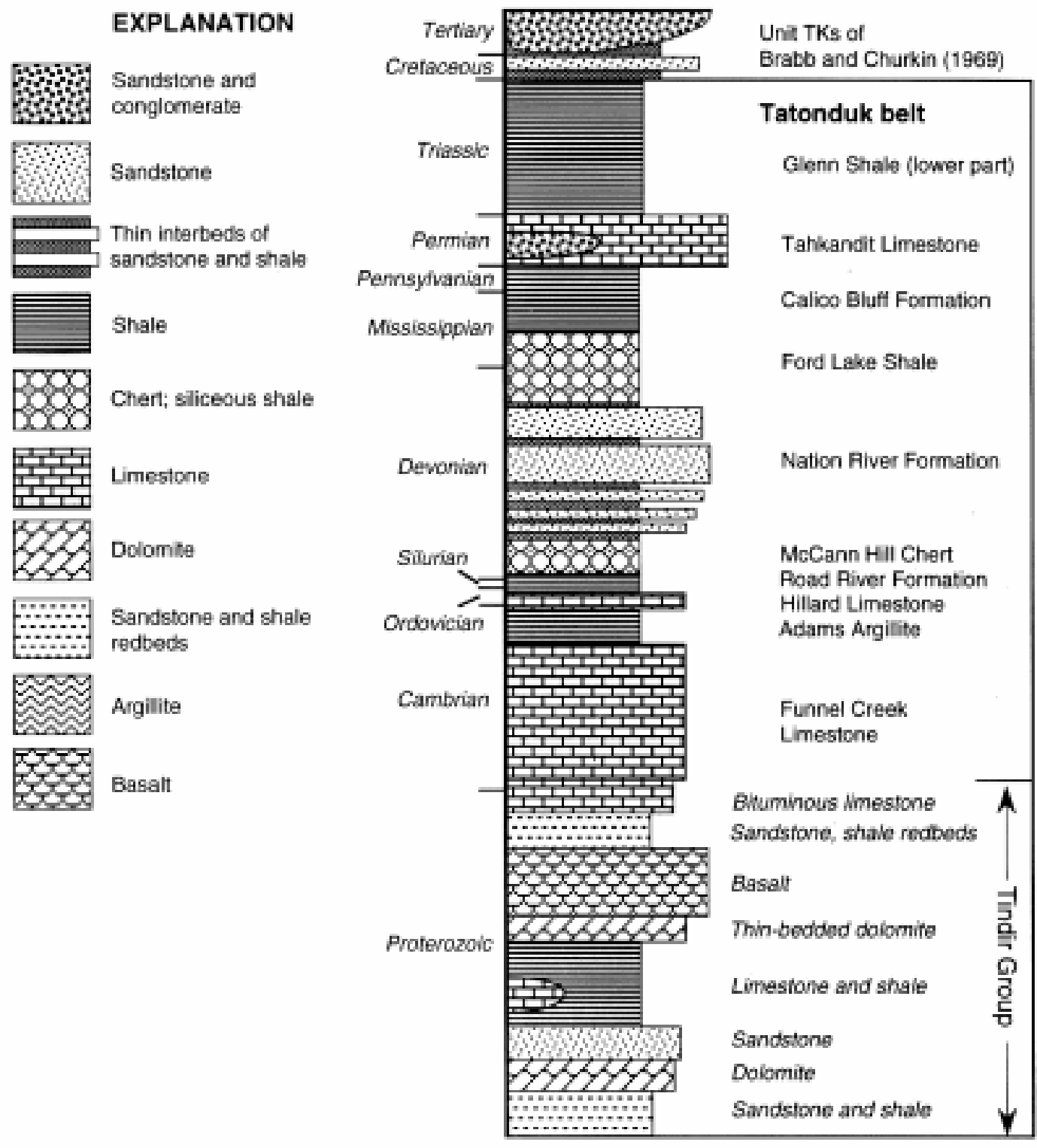

Figure 2. Schematic stratigraphic section for Tatonduk belt (Tatonduk terrane of Churkin and others, 1982) (modified from Howell and others, 1992). 
Graywacke). Fossils show that the Biederman Argillite is at least as young as late Neocomian (Miyaoka, 1990); lithologic correlations with fossiliferous strata outside of the study area suggest that the age of the Kathul Graywacke probably extends into the early Albian (Brabb, 1969; Howell and Wiley, 1987; Underwood and others, 1989). The lithologic nature and tectonostratigraphic affinity of the original depositional basement to the Kandik River terrane both remain uncertain. Howell and others (1992) speculated that the basement rocks could correlate with Paleozoic units that are exposed along the western edge of the study area and (or) in the Step Mountains (fig. 1), but the structural base of most parts of the Kandik River terrane is ambiguous.

Pre-Mesozoic strata occur in two general localities outside of the Tatonduk belt: (1) in the core of the Step Mountains antiform, and (2) within the Eureka suture zone of Churkin and others (1982). Three Paleozoic formations have been mapped in the Step Mountains: (1) conglomerate and fossiliferous limestone lenses of the Permian Step Conglomerate (Brabb, 1969), (2) undated siliceous mudrocks correlated by Brabb (1969) with the Ford Lake Shale (Upper Devonian and Mississippian), and (3) poorly dated chert-pebble conglomerates assigned to the Devonian Nation River Formation by Brabb and Churkin $(1967,1969)$ and Miyaoka (1990). Within the Eureka suture zone, the pre-Mesozoic units consist of: (1) the Devonian Woodchopper Volcanics (these rocks were called the Woodchopper Canyon terrane by Churkin and others, 1982), composed mostly of oceanic pillow basalt, (2) poorly dated interbeds of argillite and chert, sandstone and conglomerate, and limestone and dolomite (mostly units Pza and Pzl of Brabb and Churkin, 1969), which were called the Slaven Dome terrane by Churkin and others (1982), and (3) the Permian Step Conglomerate plus Proterozoic(?) deposits of undivided sedimentary rocks, dolomite, and volcanic rocks (the Takoma Bluff terrane of Churkin and others, 1982). The map of Dover and Miyaoka (1988) shows widespread occurrences of Devonian conglomerates (Nation River Formation rather than the Step Conglomerate) within the Takoma Bluff terrane, but fossil control for most of these chert-pebble conglomerates is lacking. Collectively, these rocks have been included in the Porcupine terrane of Jones and others (1987), which extends well to the north of our study area.

The youngest rocks within the Kandik study area belong to unit TKs of Brabb and Churkin (1969). These strata are Late Cretaceous and early Tertiary (Eocene and Oligocene) in age (Dover and Miyaoka, 1988; Miyaoka, 1990). Unit TKs unconformably overlies rocks of the Tatonduk belt, the Kandik River terrane, and the southern edge of the Eureka suture zone. Its lithologies consist of poorly indurated interbeds and lenses of conglomerate, sandstone, and mudrock, plus local coal seams and fossilized plant fragments. Most of the plant fossils and palynomorphs from unit TKs do not allow precise definition of age, but lithologic correlations with strata outside of the study area indicate that the basal deposits of unit
TKs may be as old as Albian (Howell and Wiley, 1987). If these stratigraphic inferences are correct, then the hiatus between deposition of the Kathul Graywacke and unit TKs could not be more than about 10 m.y.

The principal goal of our research in the Kandik region has been to establish its tectonic and sedimentary history

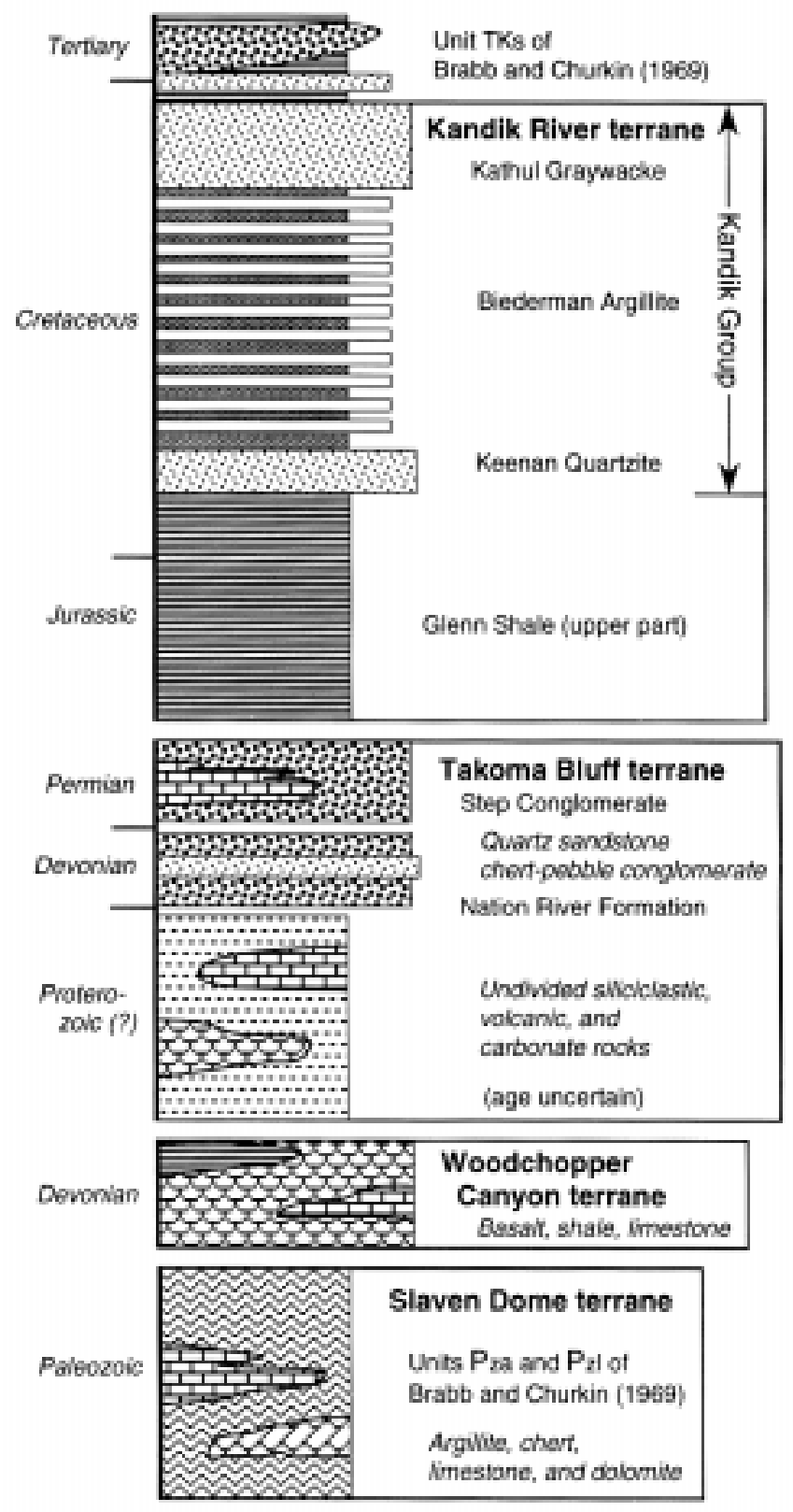

Figure 3. Schematic stratigraphic section for Kandik River terrane and rocks of Eureka suture zone (Takoma Bluff, Woodchopper Canyon, and Slaven Dome terranes) following assignments of Churkin and others (1982). We assign Precambrian (Proterozoic) rocks and Step Conglomerate to Takoma Bluff terrane, Woodchopper Volcanics to Woodchopper Canyon terrane, and units Pza and Pzl of Brabb and Churkin (1969) to Slaven Dome terrane (modified from Howell and others, 1992). See figure 2 for definition of graphic patterns used to designate lithologies. 
(Howell and others, 1992). Studies at the University of Missouri have focused on the thermal evolution of all pertinent rock units and structural domains. Past accomplishments within this framework included reconnaissance-level measurements of vitrinite reflectance and illite "crystallinity" (Underwood and others, 1989; Laughland and others, 1990), statistical correlation between indicators of thermal maturity (Underwood and others, 1992), and preliminary interpretations of fluid-rock interactions based on isotope analyses of calcite veins (Shelton and others, 1992). Collectively, those studies (see also Shelton and others, this volume) showed that nearly all of the rocks within the Kandik River terrane attained significantly higher ranks of thermal maturity than those of the Tatonduk belt. In addition, waters that were responsible for vein precipitation in the Kandik River terrane differed chemically from those of the Tatonduk belt. In this paper, we provide a detailed assessment of spatial changes in thermal maturity and relate those variations to specific structural features and tectonic events. When taken as a whole, the existing data set provides convincing evidence in support of the idea that strata to the northwest of the Glenn Creek Fault Zone are allochthonous with respect to the rifted Proterozoic edge of North America.

\section{BASIC PRINCIPLES}

\section{ILLITE CRYSTALLINITY}

Many techniques are available to help document peak burial temperatures and pressures (for example, Kisch, 1983; Liou and others, 1987; Frey, 1987). One widely used method for characterizing specific levels of diagenesis and incipient metamorphism is measurement of the illite-crystallinity index (CI) by X-ray diffraction (XRD). This procedure (which is based on the width of the $10 \AA$ illite peak at half height) is rapid, simple, inexpensive, and applicable over a fairly wide variety of geologic conditions. Under ideal circumstances, CI data can document relatively subtle differences among individual samples. Unfortunately, the reliability of CI data in regions of low thermal maturity is suspect because the diagenetic signal can be contaminated by occurrences of wellcrystallized detrital white mica. Moreover, results are affected by a host of external and internal variables, including maximum temperature, heating time, protolith geochemistry, the composition and migration history of pore fluid, and rock deformation (Frey, 1987; Kisch, 1987).

Robinson and others (1990) completed studies of error and precision and concluded that geologic interpretations of $\mathrm{CI}$ gradients and anomalies should be based on differences in the $10 \AA$-peak width of at least $0.1 \Delta^{\circ} 2 \theta$. Pinpointing the zonal boundaries between diagenesis and incipient greenschist-facies or blueschist-facies metamorphism (anchizone to epizone transition) has been problematic because of operational in- consistencies in sample preparation, analytical equipment, and analytical technique (see Kisch, 1987, 1990; Kisch and Frey, 1987; Robinson and others, 1990 for comprehensive discussions of these problems). Blenkinsop (1988) advocated the following values of $\mathrm{CI}$ for the two principal boundaries of thermal alteration: diagenesis/anchizone boundary $=0.42 \Delta^{\circ} 2 \theta$ and anchizone/epizone boundary $=0.25 \Delta^{\circ} 2 \theta$. For the specific lithologies of the Kandik study area, interested readers should refer to Underwood and others (1992) for a complete discussion of factors that affected the correlation between organic and inorganic metamorphism.

\section{VITRINITE REFLECTANCE AND PALEOTEMPERATURE}

General applications of the vitrinite-reflectance technique have been described by Dow (1977) and Bostick (1979). Unlike illite crystallinity, mean random vitrinite reflectance $\left(R_{m}\right)$ increases primarily in response to higher burial temperatures, thereby serving as a more direct indicator of maximum heating (Barker, 1989, 1991). Time-dependent models of organic metamorphism (for example, Hood and others, 1975; Bostick and others, 1978; Waples, 1980; Middleton, 1982; Ritter, 1984; Wood, 1988; Hunt and others, 1991) are useful for conventional studies of petroleum potential within firstcycle sedimentary basins. However, serious problems are encountered in the application of these models if one's goal is to calculate maximum paleotemperatures with any degree of accuracy, particularly within uplifted orogenic sequences where the tectonic and thermal histories can be very complicated and constrained by imprecise or inaccurate data. In addition to the guesswork involved in the selection of appropriate values of activation energy for a given rock unit (Antia, 1986; Wood, 1988), large uncertainties usually exist in the inferred reaction rates for time-temperature integrals (Issler, 1984; Ritter, 1984), not to mention uncertainties in choices of effective heating time. The kinetic models are particularly troublesome at high ranks of thermal maturity because of insufficient calibration; problems also arise if heating conditions lead to organic reactions that are not first order. Conversely, many empirical and theoretical studies over the past decade have demonstrated that vitrinite reflectance is affected most by maximum temperature and almost imperceptibly by the duration of heating, at least under typical geologic situations where time is measured in millions of years (Wright, 1980; Gretener and Curtis, 1982; Suggate, 1982; Barker, 1983, 1989, 1991; Price, 1983; Barker and Pawlewicz, 1986). These workers, in other words, have argued that the time required for stabilization of kerogen maturation at a given burial temperature is usually on the order of $1 \mathrm{~m} . \mathrm{y}$. or less.

Several statistical correlations now exist between $R_{m}$ and absolute paleotemperature, with the temperature scales having been established through direct borehole measurements (Barker, 1983, 1988; Price, 1983; Barker and 
Pawlewicz, 1986). The Barker (1988) regression yields the lowest temperature estimates for a given value of $R_{m}$, as compared with other time-independent solutions. Recent models based on chemical kinetics (Burnham and Sweeney, 1989; Sweeney and Burnham, 1990) match the curve of Barker (1988) quite closely, provided the inferred heating time is limited to 1 m.y. or less. Furthermore, Barker and Goldstein (1990) arrived at a close match between homogenization temperatures of fluid inclusions (which are not affected by heating duration) and estimates of paleotemperature derived from the Barker and Pawlewicz (1986) regression analysis. The Barker (1988) equation is based on the same set of data as shown by Barker and Pawlewicz (1986), but the statistical model is more defensible. In addition, paleotemperatures calculated using the Barker (1988) equation are internally consistent with the results of our measurements of fluid-inclusion homogenization temperatures (Shelton and others, this volume). Thus, for the purposes of providing a straightforward estimate of peak burial temperature, we prefer the equation of Barker (1988). The relevant equation is:

$$
T\left({ }^{\circ} \mathrm{C}\right)=148+104\left[\ln \left(R_{m}\right)\right] .
$$

Because of the propagation of total error resulting from errors in individual measurements of both borehole temperature and vitrinite reflectance, it is difficult to establish a statistically rigorous error bar for paleotemperature estimates using this particular equation. Visual estimates of scatter about the regression curve suggest a spread of roughly $\pm 30^{\circ} \mathrm{C}$ for a given value of $R_{m}$.

To provide a means of fair comparison, and in acknowledgment of the possible influence of kinetic factors for strata with vastly different thermal histories, we have also calculated paleotemperatures using one iteration of the EASY\%R model (Sweeney and Burnham, 1990). Although many combinations of input parameters might be viewed as reasonable, we have fixed the duration of heating at the following values: (1) 5 m.y. for the Kandik River, Woodchopper Canyon, and Slaven Dome terranes, (2) 200 m.y. for the Tatonduk belt (mostly the Devonian Nation River Formation), and (3) 50 m.y. for unit TKs. These crude estimates of effective heating time are based on: (1) the evidence discussed herein for rapid heating, uplift, and cooling of the Lower Cretaceous Kandik Group during Albian time, (2) the elapsed time associated with semiconformable deposition from the Nation River Formation (Upper Devonian) to the upper part (Jurassic and Lower Cretaceous) of the Glenn Shale, and (3) the average time elapsed since accumulation of the synorogenic to postorogenic cover sequence (Cenomanian(?) to Oligocene).

\section{ESTIMATES OF DEPTH AND PRESSURE}

It is particularly difficult in orogenic belts to establish the precise depth of burial for a given parcel of rock at the time of peak heating. This is because structural position during peak heating rarely corresponds to the relative or absolute stratigraphic level inherited from primary depositional events. One method for estimating pressure maxima is through $\mathrm{X}$-ray diffraction (XRD) measurements and calculation of the dimension of the $b_{0}$ unit cell within the crystal lattice of potassic white mica and illite (Sassi and Scolari, 1974; Padan and others, 1982; Guidotti and Sassi, 1976, 1986). If the temperature and bulk-rock composition are reasonably uniform, then $b_{0}$ values should increase as a function of increasing pressure in response to larger $\mathrm{Fe}$ and $\mathrm{Mg}$ cations that substitute into the octahedral site (that is, the mica becomes more phengitic in the muscovite-celadonite solid-solution series). At the lowest grades of metamorphism, however, $b_{0}$ data typically display the effects of mixing among chemically diverse populations of detrital and authigenic illite/mica (Frey, 1987). Moreover, for a given rock parcel, temporal constraints on maximum burial pressure do not necessarily correlate with peak heating time. Nevertheless, reasonable limits usually can be placed on paleogeothermal gradients by dividing maximum paleotemperatures by depths derived from the pressure maxima (for example, Underwood, 1989; Underwood and others, 1993).

Fluid pressures at the time of vein precipitation can be calculated in two ways (Shelton and others, this volume). First, one can compare temperatures derived from oxygen-isotope fractionations between quartz and calcite with homogenization temperatures $\left(T_{h}\right)$ for fluid inclusions in the same veins. Temperature differences thus calculated represent the "pressure correction" to the $T_{h}$ values (Potter, 1977). For veins with methane-bearing fluid inclusions, fluid pressure at the time of entrapment can be determined if one measures the methane densities and the $T_{h}$ values of contemporaneous waterrich inclusions. Maximum and minimum burial depths then can be calculated for a given fluid pressure by assuming purely lithostatic or hydrostatic pressure regimes, respectively. Naturally, the fluid pressure during vein precipitation will be less than the rock pressure at the time of peak burial if the veins form during a decompression phase in the P-T-t pathway.

\section{METHODS}

\section{SAMPLING}

Specimens of coal, fossilized wood fragments, shale, and their low-grade metamorphic equivalents were collected from fresh outcrop exposures throughout the study area, as well as from well cuttings associated with a single borehole (Doyon No. 1). Virtually all of the Devonian and younger mudrock-bearing formations within the Kandik region were sampled (table 1), and the resulting data are quite consistent considering the diversity of lithologies analyzed. All formational assignments used herein conform to the maps of Brabb 
and Churkin (1969) and Foster (1976), which were used as geologic templates for sampling in the field. Additional details regarding structural interpretations and fossil localities have been provided by Dover and Miyaoka (1988), Miyaoka (1990), and Dover (1992).

\section{VITRINITE REFLECTANCE}

Most of our vitrinite-reflectance data come from dispersed organic particles that were concentrated from mudstones, shales, and argillites via acid maceration and density segregation. However, fossil wood fragments and coal seams also were collected and analyzed whenever possible; large pieces of organic matter are particularly common in unit TKs. The standard U.S. Geological Survey techniques for sample preparation and optical measurements of vitrinite reflectance have been described at length elsewhere (Baskin, 1979; Barker, 1982; Pawlewicz, 1987). Comparisons of interlaboratory reproducibility show that results from higherrank samples diverge much more than those from low-rank samples (Dembicki, 1984). Consequently, to improve consistency, several samples from the preliminary Kandik study (Underwood and others, 1989) have been reanalyzed (table 1). For the purpose of assessing and comparing paleotemperature, we calculated mean vitrinite-reflectance values $\left(R_{m}\right)$ following measurements (in oil) of at least 20 individual randomly oriented particles per specimen (table 1). Barker and Pawlewicz (1993) showed that only 20 to 30 particles are required to generate a mean vitrinite-reflectance value that is within 5 percent of the "true" value (based on 100 measurements). Data from lean samples ( $« 20$ particles) can be reliable for paleotemperature analysis provided the standard deviation is less than 0.1 percent reflectance. Many samples from the Kandik region (particularly from chert-andshale units) contain insufficient amounts of terrigenous organic matter and (or) have high standard deviations in mean vitrinite-reflectance values, such that statistics remain suspect. For localities of critical geologic interest, we display the data from lean samples (10 to 20 measurements per sample) on maps but urge caution in their interpretation. Samples with fewer than 10 measured vitrinite particles have been classified as barren and are not considered in the geologic interpretations.

\section{X-RAY DIFFRACTION}

Techniques used to determine illite crystallinity indices have been described in detail by Underwood and others (1992). In addition to this parameter, we also measured the $b_{0}$ lattice dimension of illite/mica for 45 representative samples by scanning random-powder mounts (saturated with ethylene glycol) over an angular range of $59^{\circ}$ to $63^{\circ} 2 \theta$ at a rate of $1^{\circ} 2 \theta / \mathrm{min}$. Digital output from the Scintag PAD V X-ray diffraction system was processed through a back-
Table 1. Levels of organic metamorphism and estimates of paleotemperature for tectonostratigraphic domains of Kandik region, east-central Alaska.

$\left[R_{m}\right.$, mean random vitrinite reflectance; No. gr., number of vitrinite particles counted per specimen; Std. dev., standard deviation about mean vitrinite reflectance; EASY\% $\mathrm{R}_{0}$, model of Sweeney and Burnham (1990); NA, not applicable; - - -, not calculated]

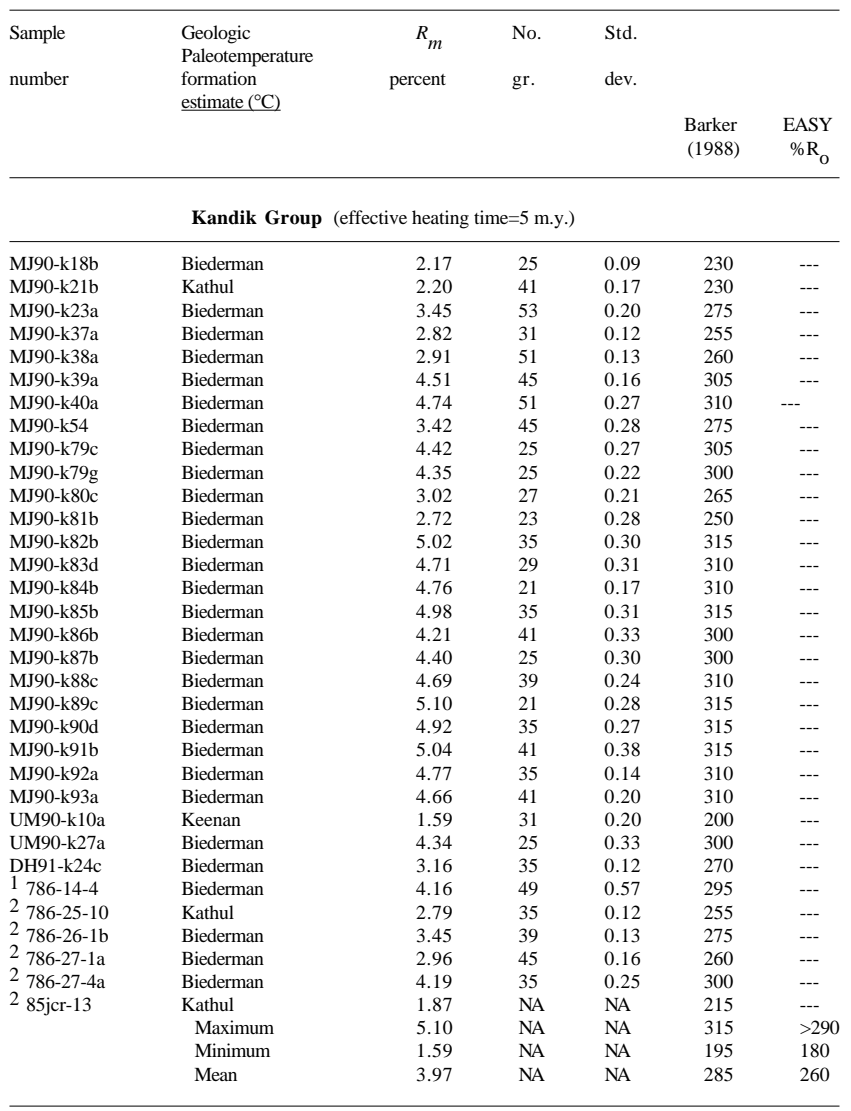

Glenn Shale (upper part) (effective heating time $=5$ m.y.)

\begin{tabular}{|c|c|c|c|c|c|c|}
\hline \multicolumn{2}{|l|}{ MJ90-k17a } & 3.41 & 21 & 0.27 & 275 & -.- \\
\hline \multicolumn{2}{|l|}{ MJ90-k41a } & 3.94 & 51 & 0.33 & 290 & -.. \\
\hline \multicolumn{2}{|l|}{ MJ90-k41b } & 4.37 & 42 & 0.19 & 300 & -.- \\
\hline \multicolumn{2}{|l|}{ MJ90-k43b } & 4.25 & 35 & 0.23 & 300 & --- \\
\hline \multicolumn{2}{|l|}{ UM90-k9a } & 2.68 & 25 & 0.13 & 250 & --- \\
\hline \multicolumn{2}{|l|}{ UM90-k17 } & 1.66 & 35 & 0.14 & 200 & --- \\
\hline \multicolumn{2}{|l|}{ UM90-k18 } & 3.03 & 41 & 0.28 & 265 & --- \\
\hline \multicolumn{2}{|l|}{ UM $90-\mathrm{k} 20$} & 3.38 & 25 & 0.25 & 275 & -.. \\
\hline \multicolumn{2}{|l|}{ UM90-k21 } & 2.25 & 25 & 0.24 & 230 & --- \\
\hline \multicolumn{2}{|l|}{ UM90-k24a } & 4.29 & 31 & 0.16 & 300 & -.. \\
\hline \multicolumn{2}{|l|}{ UM90-k25c } & 3.87 & 45 & 0.17 & 290 & --. \\
\hline \multicolumn{2}{|l|}{ UM90-k26b } & 4.80 & 35 & 0.19 & 310 & -.- \\
\hline \multicolumn{2}{|l|}{ UM90-k28a } & 4.61 & 39 & 0.28 & 305 & -- \\
\hline \multicolumn{2}{|l|}{ UM90-k31a } & 4.13 & 45 & 0.15 & 295 & --- \\
\hline \multicolumn{2}{|l|}{ UM90-k78f } & 4.11 & 35 & 0.17 & 295 & --- \\
\hline \multicolumn{2}{|l|}{ DH91-k4a } & 4.27 & 45 & 0.23 & 300 & -.- \\
\hline \multicolumn{2}{|l|}{ DH91-k5a } & 4.35 & 41 & 0.25 & 300 & -.- \\
\hline \multicolumn{2}{|l|}{ DH91-k10a } & 3.87 & 51 & 0.18 & 290 & --- \\
\hline \multicolumn{2}{|l|}{ DH91-k10b } & 3.82 & 51 & 0.16 & 285 & --. \\
\hline \multicolumn{2}{|l|}{ DH91-k19a } & 3.67 & 41 & 0.20 & 285 & -.- \\
\hline \multicolumn{2}{|l|}{ DH91-k19b } & 3.55 & 35 & 0.15 & 280 & -- \\
\hline \multirow{2}{*}{\multicolumn{2}{|c|}{ UM91-k1a }} & 3.77 & 21 & 0.16 & 285 & --- \\
\hline \multirow[t]{4}{*}{ UM91-k1b } & & 3.82 & 21 & 0.21 & 285 & --- \\
\hline & Maximum & 4.80 & $\mathrm{NA}$ & NA & 310 & $>290$ \\
\hline & Minimum & 1.66 & NA & NA & 200 & 180 \\
\hline & Mean & 3.67 & NA & NA & 285 & 255 \\
\hline
\end{tabular}


Table 1. Continued.

\begin{tabular}{llclcll}
\hline Sample & $\begin{array}{l}\text { Geologic } \\
\text { Paleotemperature }\end{array}$ & $R_{m}$ & No. & Std. & & \\
formation & percent & gr. & dev. & & \\
& estimate $\left({ }^{\circ} \mathrm{C}\right)$ & & & & $\begin{array}{c}\text { Barker } \\
(1988)\end{array}$ & $\begin{array}{c}\text { EASY } \\
\% \mathrm{R}_{\mathrm{o}}\end{array}$
\end{tabular}

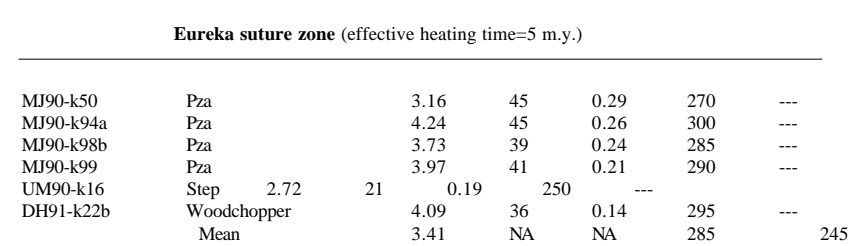

\begin{tabular}{|c|c|c|c|c|c|c|}
\hline \multicolumn{7}{|c|}{ Step Mountains (effective heating time $=5$ m.y.) } \\
\hline MJ90-k4 & Ford Lake & 2.52 & 21 & 0.19 & 245 & --- \\
\hline MJ90-k5 & Nation River & 2.50 & 21 & 0.60 & 245 & --- \\
\hline MJ90-k6 & Nation River & 3.70 & 25 & 0.25 & 285 & -- \\
\hline \multirow[t]{2}{*}{ MJ90-k11 } & Ford Lake & 3.88 & 31 & 0.18 & 290 & --- \\
\hline & Mean & 3.15 & NA & NA & 265 & \\
\hline
\end{tabular}

Tatonduk belt (effective heating time $=200$ m.y.)

\begin{tabular}{|c|c|c|c|c|c|c|c|c|}
\hline MJ90-k31b & Nation River & 0.70 & & 51 & 0.03 & & 110 & -- \\
\hline${ }^{3}$ MJ90-k32a & Road River (coal) & 1.19 & & 50 & 0.10 & & 165 & --- \\
\hline MJ90-k34a & Nation River & 0.84 & & 23 & 0.05 & & 130 & -- \\
\hline MJ90-K35c & Nation River & 0.69 & & 35 & 0.06 & & 110 & --- \\
\hline MJ90-k59a & Nation River & 1.62 & & 45 & 0.09 & & 200 & -- \\
\hline MJ90-k68d & Nation River & 0.56 & & 31 & 0.03 & & 90 & -- \\
\hline${ }^{3}$ MJ90-k69c & Nation River (coal) & 0.57 & & 50 & 0.04 & & 90 & -- \\
\hline MJ90-k69d & Nation River & 0.62 & & 31 & 0.06 & & 100 & --- \\
\hline MJ90-k70a & Nation River & 0.57 & & 31 & 0.06 & & 90 & --- \\
\hline MJ90-k71a & Nation River & 0.89 & & 25 & 0.09 & & 135 & --. \\
\hline MJ90-k72a & Nation River & 0.80 & & 25 & 0.07 & & 125 & --- \\
\hline UM90-k54c & Nation River & 0.70 & & 25 & 0.10 & & 110 & --. \\
\hline TB $90-k 59 \mathrm{c}$ & NationRiver & 0.83 & 31 & & 0.06 & 130 & & --- \\
\hline 3 TВ90-k59b & Nation River (coal) & 0.97 & & 50 & 0.07 & & 145 & --- \\
\hline $1786-3-2 \mathrm{c}$ & Nation River & 0.61 & & 50 & 0.11 & & 95 & -- \\
\hline $1786-3-2 \mathrm{~d}$ & Nation River & 0.90 & & 50 & 0.22 & & 135 & --- \\
\hline $1786-4-2 \mathrm{c}$ & Nation River & 0.71 & & 49 & 0.15 & & 110 & --- \\
\hline $1786-30-3$ & McCann Hill & 1.13 & & 48 & 0.19 & & 160 & --- \\
\hline $1886-1-2$ & Road River & 0.72 & & 50 & 0.16 & & 115 & -- \\
\hline 185 jcr-24 & Nation River & 0.82 & & 50 & 0.16 & & 125 & --- \\
\hline \multirow[t]{4}{*}{$185 j \mathrm{jcr}-25 \mathrm{~b}$} & Road River & 0.97 & & 50 & 0.15 & & 145 & -.- \\
\hline & Maximum & 1.62 & & NA & NA & & 200 & 155 \\
\hline & Minimum & 0.56 & & NA & NA & & 90 & 75 \\
\hline & Mean & 0.83 & & $N$ & NA & & 130 & 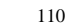 \\
\hline
\end{tabular}

\begin{tabular}{|c|c|c|c|c|c|c|}
\hline \multicolumn{7}{|c|}{ Footwall aureole (effective heating time $=2$ m.y.) } \\
\hline MJ90-k74 & Nation River & 1.19 & 25 & 0.08 & 165 & --- \\
\hline TB90-k49c & Nation River & 2.44 & 51 & 0.15 & 240 & --- \\
\hline TB90-k50b & Nation River & 2.82 & 25 & 0.13 & 255 & --- \\
\hline TB90-k51a & Nation River & 2.75 & 45 & 0.13 & 255 & -- \\
\hline TB $90-\mathrm{k} 52 \mathrm{a}$ & Nation River & 2.64 & 39 & 0.13 & 250 & --- \\
\hline TB90-k53c & Nation River & 2.45 & 25 & 0.15 & 240 & --- \\
\hline $2786-29-1$ & Nation River & 2.04 & 48 & 0.29 & 220 & --- \\
\hline DH91-k13a & Nation River & 3.01 & 41 & 0.19 & 265 & --- \\
\hline DH91-k13b & Nation River & 2.96 & 51 & 0.12 & 260 & --- \\
\hline \multirow{2}{*}{$2786-7-3$} & Glenn (lower part) & 2.83 & 50 & 0.40 & 255 & --- \\
\hline & Mean & 2.51 & NA & NA & 245 & 220 \\
\hline
\end{tabular}

ground correction and a deconvolution program designed to fit the resulting peaks to model peak geometries (based on a Split Pearson VII (Gaussian-Lorentzian hybrid) profile shape). Dimensions of the $b_{0}$ unit cell were calculated from the corrected d-spacing of the dioctahedral (060) peak. The quartz (211) reflection (d-spacing $=1.5418 \AA$ ) served as an internal standard to eliminate the effects of instrument drift and changes in alignment of the sample holder.
Table 1. Continued.

\begin{tabular}{|c|c|c|c|c|c|c|}
\hline \multirow[t]{2}{*}{$\begin{array}{l}\text { Sample } \\
\text { number }\end{array}$} & \multirow[t]{2}{*}{$\begin{array}{l}\text { Geologic } \\
\text { formation }\end{array}$} & \multirow[t]{2}{*}{$\begin{array}{c}R_{m} \\
\text { percent }\end{array}$} & \multirow[t]{2}{*}{$\begin{array}{l}\text { No. } \\
\text { gr. }\end{array}$} & \multirow[t]{2}{*}{$\begin{array}{l}\text { Std. } \\
\text { dev. }\end{array}$} & \multicolumn{2}{|c|}{$\begin{array}{l}\text { Paleotemperature } \\
\text { estimate }\left({ }^{\circ} \mathrm{C}\right)\end{array}$} \\
\hline & & & & & $\begin{array}{l}\text { Barker } \\
\text { (1988) }\end{array}$ & $\begin{array}{c}\text { EASY } \\
\% \mathrm{R}_{0}\end{array}$ \\
\hline
\end{tabular}

\begin{tabular}{|c|c|c|c|c|c|c|c|}
\hline \multicolumn{8}{|c|}{ Unit TKs (effective heating time $=50$ m.y.) } \\
\hline 3 UM90-k12 & TKs (coal) & 0.40 & 50 & 0.01 & 55 & & --- \\
\hline 3 UM90-k12 & TKs (coal) & 0.39 & 50 & 0.04 & 50 & -..- & \\
\hline 3 UM90-k22a & TKs (coal) & 0.55 & 50 & 0.05 & 85 & --- & \\
\hline 3 UM90-k22b & TKs (coal) & 0.47 & 50 & 0.04 & 70 & -.- & \\
\hline 3 MJ90-k58a & TKs (coal) & 0.82 & 50 & 0.07 & 130 & --- & \\
\hline 3 MJ90-k66b & TKs (coal) & 0.48 & 50 & 0.03 & 70 & -.- & \\
\hline 3 MJ90-k66c & TKs (coal) & 0.55 & 50 & 0.05 & 85 & --- & \\
\hline 3 MJ90-k95a & TKs (coal) & 0.48 & 50 & 0.05 & 70 & -.- & \\
\hline DH91-k1a & TKs (coal) & 0.30 & 35 & 0.01 & 25 & --- & \\
\hline DH91-k1c & TKs (coal) & 0.39 & 41 & 0.02 & 50 & --- & \\
\hline DH91-k7 & TKs (coal) & 0.44 & 35 & 0.03 & 65 & --- & \\
\hline DH91-k12a & TKs (coal) & 0.43 & 35 & 0.01 & 60 & --- & \\
\hline DH91-k12f & TKs (coal) & 0.41 & 35 & 0.01 & 55 & --- & \\
\hline DH91-k14 & TKs (coal) & 0.37 & 35 & 0.01 & 45 & -.- & \\
\hline DH91-k16b & TKs (coal) & 0.41 & 41 & 0.01 & 55 & -.- & \\
\hline DH91-k17b & TKs (coal) & 1.76 & 25 & 0.08 & 205 & --- & \\
\hline UM91-k2c & TKs (coal) & 0.46 & 41 & 0.03 & 65 & -.- & \\
\hline UM91-k3b & TKs (coal) & 0.46 & 41 & 0.02 & 65 & --- & \\
\hline UM91-k4a & TKs (coal) & 0.24 & 35 & 0.01 & 0 & --- & \\
\hline UM91-k4b & TKs (coal) & 0.22 & 35 & 0.01 & 0 & --- & \\
\hline MJ90-k36a & TKs (mudstone) & 0.45 & 35 & 0.03 & 65 & --- & \\
\hline MJ90-k58b & TKs (mudstone) & 0.74 & 51 & 0.05 & 115 & --- & \\
\hline MJ90-k65a & TKs (mudstone) & 0.61 & 25 & 0.04 & 95 & --- & \\
\hline UM90-k22c & TKs (mudstone) & 0.36 & 35 & 0.03 & 40 & --- & \\
\hline DH91-k3a & TKs (mudstone) & 0.43 & 51 & 0.04 & 60 & -.- & \\
\hline DH91-k9e & TKs (mudstone) & 0.77 & 35 & 0.06 & 120 & -.- & \\
\hline DH91-k9f & TKs (mudstone) & 0.35 & 51 & 0.02 & 40 & --- & \\
\hline DH91-k12d & TKs (mudstone) & 0.47 & 51 & 0.02 & 70 & -.. & \\
\hline DH91-k12e & TKs (mudstone) & 0.45 & 45 & 0.03 & 65 & --- & \\
\hline DH91-k15a & TKs (mudstone) & 0.31 & 35 & 0.02 & 25 & --- & \\
\hline & TKs (mudstone) & 0.37 & 51 & 0.02 & 45 & --- & \\
\hline \multirow[t]{4}{*}{ UM91-k2e } & TKs (mudstone) & 0.44 & 35 & 0.02 & 65 & --- & \\
\hline & Maximum & 1.76 & NA & NA & 205 & 170 & \\
\hline & Minimum & 0.22 & NA & NA & 0 & & 0 \\
\hline & Mean & 0.50 & NA & $\mathrm{NA}$ & 75 & & 75 \\
\hline
\end{tabular}

1 Sample from Underwood and others (1989) reanalyzed by Mark Pawlewicz, U.S. Geological Survey

2 Sample analyzed by Matt Laughland, University of Missouri (Underwood and others, 1989).
3 Sample analyzed by Tom Brocculeri, University of Missouri.

Prior assessments of instrument error yielded a standard deviation for duplicate runs equal to $0.002 \AA$ (Underwood and others, 1992). Chemical differences among single crystals in a low-grade metamorphic rock can be significant, so most interpretations of $b_{0}$ data are based on cumulative-frequency diagrams or histogram plots (Naef and Stern, 1982). The biggest problem with applying this method to samples at low thermal maturity is the potential for generation of a broad composite peak caused by interference or overlap among multiple populations of authigenic illite and detrital white mica. In essence, the values for unmetamorphosed rocks should be regarded as modes or averages for the illite/mica composite, and the results should be used only to identify broad categories of metamorphic conditions in the detrital source area. As defined by Guidotti and Sassi (1986), the empirical boundaries for metamorphic facies at temperatures above about $300^{\circ} \mathrm{C}$ are (1) $b_{0}<9.000 \AA=$ low-pressure facies series, (2) $9.000 \AA<b_{0}<9.040 \AA=$ intermediate-pressure facies series, and (3) $b_{0}>9.040 \AA=$ high-pressure facies series. 


\section{RESULTS AND BASIC INTERPRETATIONS}

\section{TATONDUK BELT}

Results from pre-Devonian rock units within the Tatonduk belt are restricted to CI data (Underwood and others, 1992). These specimens are too old to contain appropriate organic constituents (woody tissue), and so we have no means of establishing comparable ranks of organic metamorphism or assessing the reliability of CI values as indicators of in situ burial conditions. The CI data define an extremely erratic and wide range of apparent burial conditions, extending from the upper limit of the anchizone $\left(0.25 \Delta^{\circ} 2 \theta\right)$ into the zone of early diagenesis $\left(0.80 \Delta^{\circ} 2 \theta\right)$. It appears likely that many pre-Devonian rocks contain mixed assemblages of detrital muscovite and authigenic illite (Underwood and others, 1992).

The Nation River Formation is an important Devonian unit of inferred submarine fan deposits (sandstone turbidites, conglomerate, and shale). Vitrinite is fairly abundant in these mudrocks, a fact which supports the idea of a continental provenance for the sediment. The Nation River Formation is underlain by the McCann Hill Chert and the Road River Formation, but most samples from those formations are lean in terrigenous organic matter. With one exception, CI values from the Nation River Formation fall within the confines of the diagenetic zone (Underwood and others, 1992). Similarly, ranks of organic metamorphism are generally below 1.0 percent $R_{m}$ (table 1 ; fig. 4). Excluding a major fault-related anomaly (discussed below), the average $R_{m}$ value for Devonian strata within the Tatonduk belt is 0.83 percent, which corresponds to a paleotemperature estimate of approximately $130^{\circ} \mathrm{C}$. One anomalous sample from the southeast corner of the study area (MJ90-K59) yielded a value of 1.6 percent $R_{m}$ (fig. 5). The reason for this unusually high value remains a mystery. Another higher-rank sample (MJ90-K62) was collected from the Ford Lake Shale at Calico Bluff (fig. 5), but this siliceous pelite does not contain enough vitrinite to yield statistically reliable results.

When converted to paleotemperature estimates, $R_{m}$ data for Devonian rocks display a fairly orderly spatial pattern that can be interpreted within the framework of major structures mapped within the Tatonduk belt (fig. 6). For example, coal rank increases near the axis of the Michigan Creek anticline, drops off to the lowest values recorded along the south flank of the fold, and then increases again as one moves into the Eagle quadrangle south of $65^{\circ} \mathrm{N}$ latitude (fig. 6). Unfortunately, we do not have enough data from units other than the Nation River Formation to tell whether or not stratigraphic gradients have been retained across all of the major structures.

Consistent exceptions to the low rank of organic matter within the Nation River Formation occur only within a relatively narrow zone (exposed mostly along the Nation
River) immediately to the southeast of the Glenn Creek Fault, where $R_{m}$ values are between 2.0 percent and 3.0 percent (fig. $5)$. This important anomaly may extend as far to the southeast as the confluence of the Nation and Yukon Rivers, where sample MJ90-K74 produced a value of 1.2 percent (fig. 5). One sample of the Glenn Shale (786-7-3), which was collected from within the Glenn Creek Fault Zone near its intersection with the Yukon River, was analyzed previously by Underwood and others (1989). On the basis of mapping by Dover and Miyaoka (1988), we now believe that this locality is within the lower part of the Glenn Shale (that is, near the uppermost part of the footwall). The tectonic significance of this paleotemperature anomaly is discussed in a following section on thermal modeling.
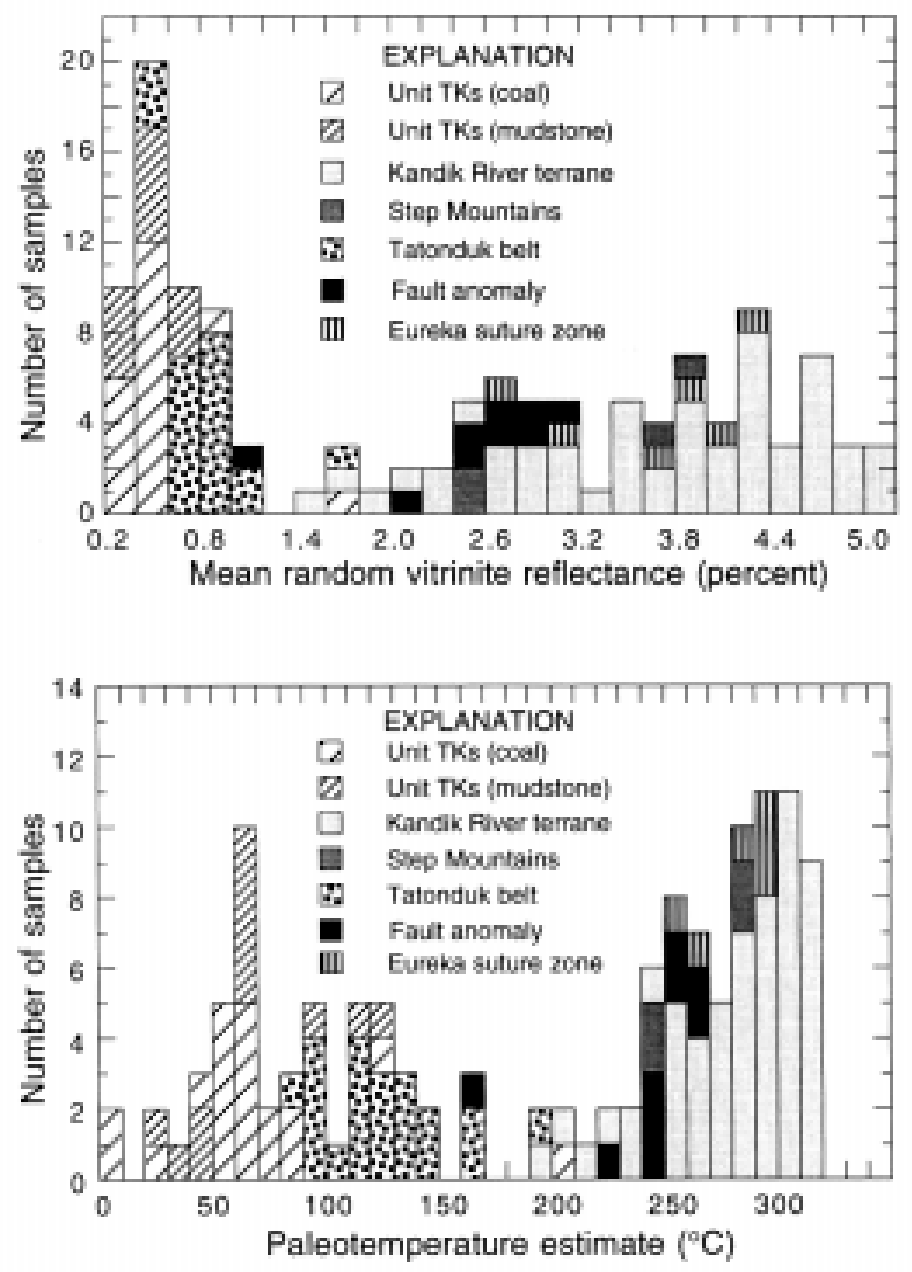

Figure 4. Histograms of mean random vitrinite-reflectance data $\left(R_{m}\right.$, in percent) from the Kandik study area and corresponding values of paleotemperature $\left({ }^{\circ} \mathrm{C}\right)$, based on regression equation of Barker (1988). See table 1 for complete listing of data. Data for Eureka suture zone combines results from Woodchopper Canyon terrane, Slaven Dome terrane, and Takoma Bluff terrane. TKs, geologic unit TKs of Brabb and Churkin (1969). 


\section{KANDIK RIVER TERRANE}

Within the Kandik River terrane, virtually all of the samples analyzed display high ranks of organic metamorphism (fig. 4). The upper part (Jurassic and Lower Cretaceous) of the Glenn Shale ranges from 1.7 to 4.8 percent $R_{m}$, with a mean value of 3.6 percent (table 1). The Kandik Group (Biederman Argillite and Kathul Graywacke) ranges from 1.6 to 5.1 percent $R_{m}$ (fig. 7), with a mean value of 3.8 percent. Overall, these $R_{m}$ values correspond to paleotemperatures of approximately $195^{\circ} \mathrm{C}$ to $315^{\circ} \mathrm{C}$ (fig. 4), with a terrane-wide average of $285^{\circ} \mathrm{C}$.

The upper part of the Glenn Shale displays excellent slaty cleavage and (or) pencil structure, which formed because of the intersection of cleavage and fissility. Similarly, all of the pelitic interbeds that we sampled from the Biederman Argillite are cleaved, and sandstone interbeds typically contain extension fractures filled with quartz and calcite veins. The ubiquitous development of cleavage is consistent with the fact that most of the Kandik River CI data fall within the boundaries of the anchizone; a few data points are within the uppermost zone of diagenesis (Underwood and others, 1992). One specimen of semischist (MJ90-K17a) falls within the zone of epimetamorphism.

Although the general level of thermal maturity within the Kandik River terrane is much higher than that of the Tatonduk belt, there are two zones with somewhat lower paleotemperatures. One zone of relatively low thermal maturity (sites UM90-K17 to UM90-K21) is associated with an east-west trending fold that has the upper part of the Glenn Shale and the Keenan Quartzite as its core; this structure (the Edwards Creek syncline) is located west of the Mardow Creek Fault (fig. 1) (as mapped by Brabb and Churkin, 1969) and west of the Andrew Creek Thrust Fault (fig. 7) (as mapped by Dover and Miyaoka, 1988). Mean vitrinite-reflectance values within this syncline range from 1.7 percent to 3.4 percent. To the north and west, the Edwards Creek syncline is truncated by the Threemile Creek Thrust Fault, which places rocks of the Tacoma Bluff terrane over the Kandik River terrane. A single sample collected from the Step Conglomerate near the Threemile Creek Fault is lean in vitrinite but yielded a mean value of 2.7 percent $R_{m}$ (fig. 7).

The largest fold within the Kandik River terrane is the northeast-trending Kathul Mountain synclinorium, which has the youngest rocks in the terrane, the Kathul Graywacke (fig. 7), as its core. Mapping by Dover and Miyaoka (1988) showed that the axis and flanks of the fold are breached by several thrust and normal faults. Most of the $R_{m}$ values from within this complicated structure (1.7 to 3.0 percent) are lower than the terrane-wide average (3.7 percent). Site MJ90-K56, located on the Kandik River near the axis of the fold, evidently exposes underlying strata of the Biederman Argillite; these pelites yield a somewhat higher $R_{m}$ value of 3.9 percent based on one lean specimen. Biederman Argillite samples to the immediate west of the fold axis, however, range from 2.8 to
3.0 percent $R_{m}$. We conclude, therefore, that the core of the synclinorium corresponds to the highest structural position within the Kandik River terrane, a conclusion which would explain the occurrence of lower paleotemperatures (fig. 6). The highest structural position at the time of peak heating, however, did not necessarily correspond to the youngest stratigraphic horizons within the Kandik Group.

There is no convincing evidence to show that primary stratigraphic gradients in thermal maturity have been preserved anywhere within the Kandik River terrane. For example, there appear to be no meaningful differences between the upper part of the Glenn Shale (near the stratigraphic base of the Kandik River terrane) and the Biederman Argillite (near the top of the Kandik River terrane). According to Brabb and Churkin (1969), this stratigraphic interval from the upper part of the Glenn Shale to the top of the Biederman Argillite reaches a cumulative thickness of approximately 1,500 to $2,000 \mathrm{~m}$. Moreover, one shale sample from the basal part of the Keenan Quartzite (UM90-K10, south of the Step Mountains) produced the lowest $R_{m}$ value for the Kandik River terrane. Thus, there are no consistent correlations between depositional age and thermal maturity within the Kandik River terrane.

As a second argument against retention of stratigraphic gradients in thermal maturity, it should be noted that the lowest paleotemperature values $\left(195^{\circ}\right.$ to $\left.215^{\circ} \mathrm{C}\right)$ would require approximately $4 \mathrm{~km}$ of post-Early Cretaceous overburden, even with an assumed surface temperature of $20^{\circ} \mathrm{C}$ and an average geothermal gradient of $45^{\circ} \mathrm{C} / \mathrm{km}$ (justification of these assumptions is given below). Although the overlying deposits of unit TKs could be sufficient to account for some of this overburden by normal sedimentation, there is ample evidence from apatite-fission-track analyses (see following discussion) to support the idea of rapid uplift and erosion of Kandik River strata during deposition of unit TKs. Moreover, there is a very large gap in thermal maturity across the angular unconformity at the base of unit TKs, which means that peak heating of the Kandik Group and upper part of the Glenn Shale must have occurred prior to development of the unconformity. Therefore, the paleothermal structure now exposed at the surface probably was produced through internal thrust imbrication and folding within the Kandik River terrane.

\section{DOYON NO. 1 WELL}

Measurements of vitrinite reflectance have been completed on well cuttings from 30 horizons within the Doyon No. 1 borehole, which was spudded in the upper part of the Glenn Shale in the north-central part of the Kandik River terrane (fig. 7). The lowest $R_{m}$ value near the top of the well is 4.0 percent (fig. 8), and the highest value (5.0 percent) corresponds to a depth of approximately 2,408 m $(7,900 \mathrm{ft})$. Paleotemperatures range from approximately $290^{\circ}$ to $315^{\circ} \mathrm{C}$ (fig. 8). Because of the inversion of formations (Glenn Shale 


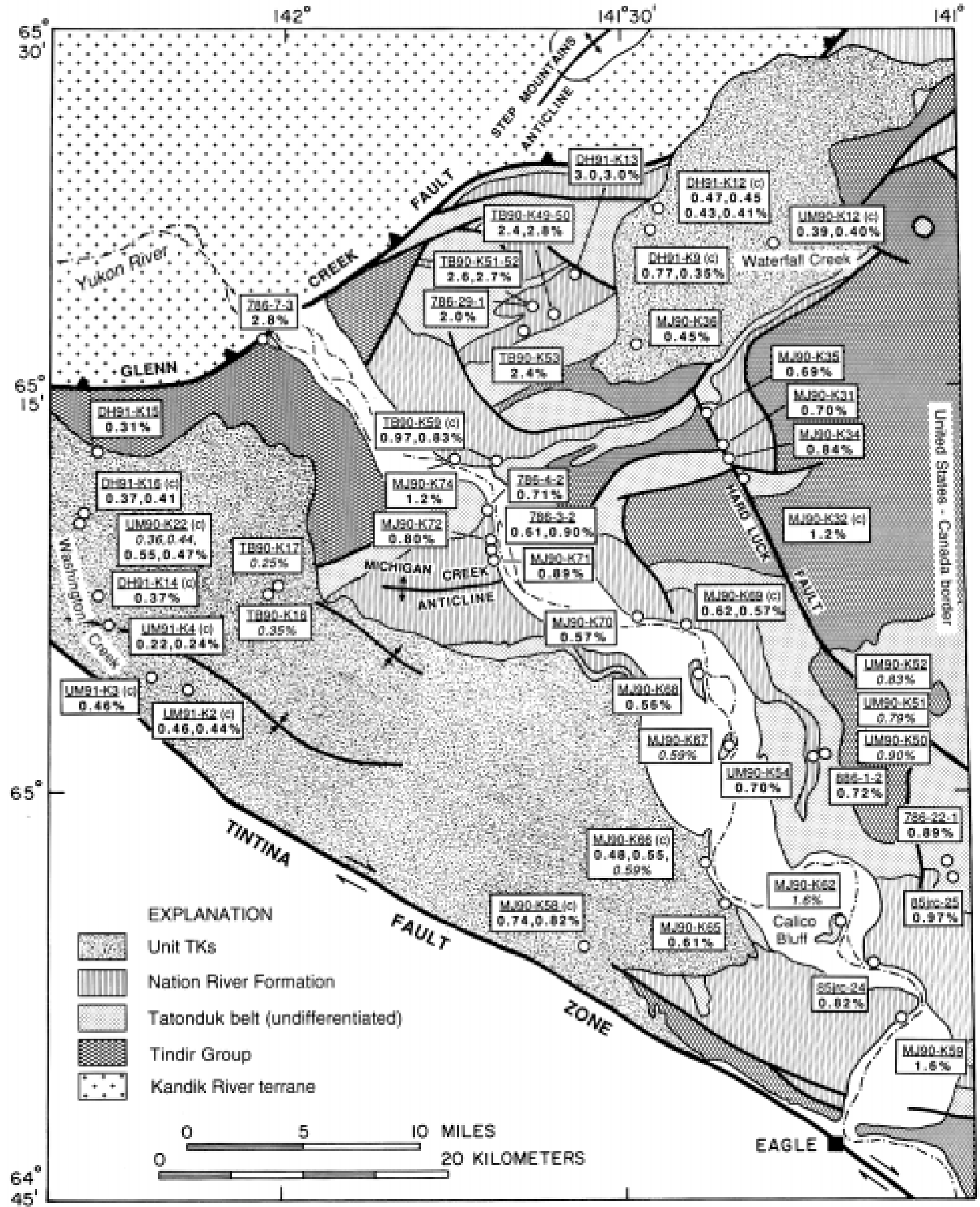

Figure 5. Map of Tatonduk belt and unit TKs of Brabb and Churkin (1969) showing sample localities and values of mean random vitrinite reflectance $\left(R_{m}\right.$, in percent). Multiple $R_{m}$ values correspond to localities from which multiple samples were collected and analyzed. A "(c)" next to sample number indicates specimen of coal or fossilized wood fragment. Numbers in italic correspond to specimens for which organic matter is insufficient to yield statistically reliable results (number of measured particles per specimen $=10$ to 20 ). See table 1 for additional statistical information. Area without drafting pattern along Yukon River corresponds to floodplain lacking outcrops of bedrock. Rocks southwest of Tintina Fault Zone are assigned to Yukon-Tanana composite terrane (Coney and Jones, 1985). Simplified geologic base is modified from Brabb and Churkin (1969) and Foster (1976). See figure 1 for explanation of map symbols. 
over the Biederman Argillite) at approximately 335 and 2,470 $\mathrm{m}$, major thrust faults evidently break the succession near those horizons. In addition, the borehole penetrated several additional intraformational faults with smaller amounts of vertical offset.

Mean vitrinite-reflectance values from the upper 900 to $1,000 \mathrm{~m}$ define a fairly consistent positive gradient, although the paleotemperature difference over this interval is no more than about $20^{\circ} \mathrm{C}$ (fig. 8). Below $1,000 \mathrm{~m}$, there is a pronounced change in slope in the $R_{m}$ gradient, with nearly isothermal conditions maintained to a depth of $2,400 \mathrm{~m}$. Mean vitrinite-reflectance values increase slightly just above the inferred thrust fault at $2,470 \mathrm{~m}$; below the fault, there is a second isothermal segment (fig. 8). The well was cased beginning at a depth of $729 \mathrm{~m}$, so some (or all) of the irregular thermal-maturity gradient could be due to contamination of well cuttings caused by cavings from above the casing. On the other hand, discontinuous thermal-maturity profiles can be caused by a variety of legitimate geological processes, such as the formation of unconformities (Dow, 1977; Katz and others, 1988). "Kinky" $R_{m}$ gradients, moreover, are common within regions exposed to unusual forms of heating, such as geothermal fields, sedimentary successions overlain by volcanic flows, and basins subjected to overpressured fluid conditions (Summer and Verosub, 1987, 1992; Law and others, 1989).

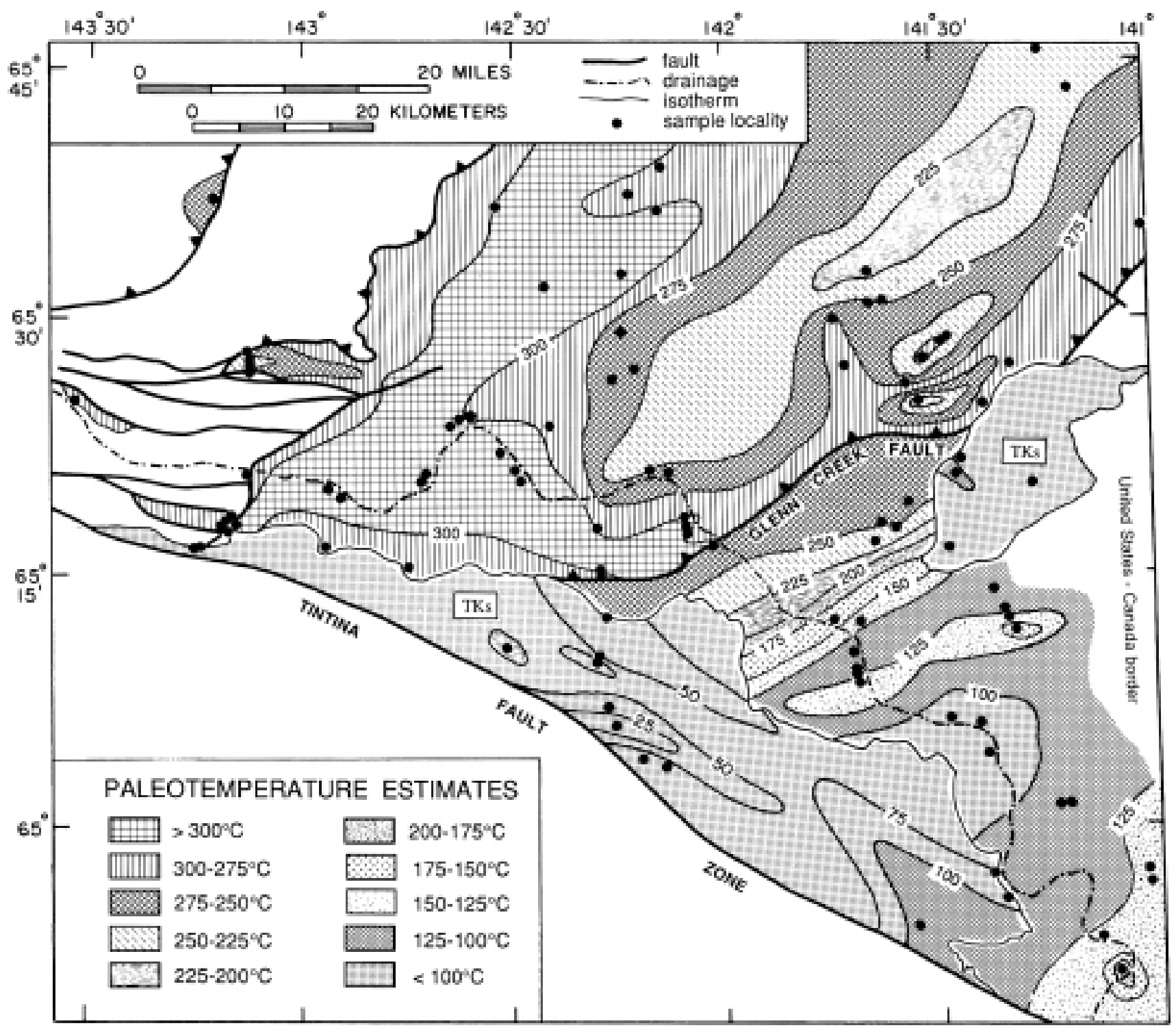

Figure 6. Contour map of paleotemperature estimates for Kandik study area. Conversions from mean random vitrinite reflectance to degrees Celsius follow regression equation of Barker (1988). Regions with insufficient data to constrain orientation of contour lines are shown without drafting patterns. TKs, geologic unit TKs of Brabb and Churkin (1969). Drafting patterns are broken along contacts of unit TKs to emphasize contrast in paleothermal structure across that unconformity. Rocks southwest of Tintina Fault Zone are assigned to Yukon-Tanana composite terrane (Coney and Jones, 1985). See figure 1 for identification and distribution of major tectonostratigraphic units within Kandik study area. 


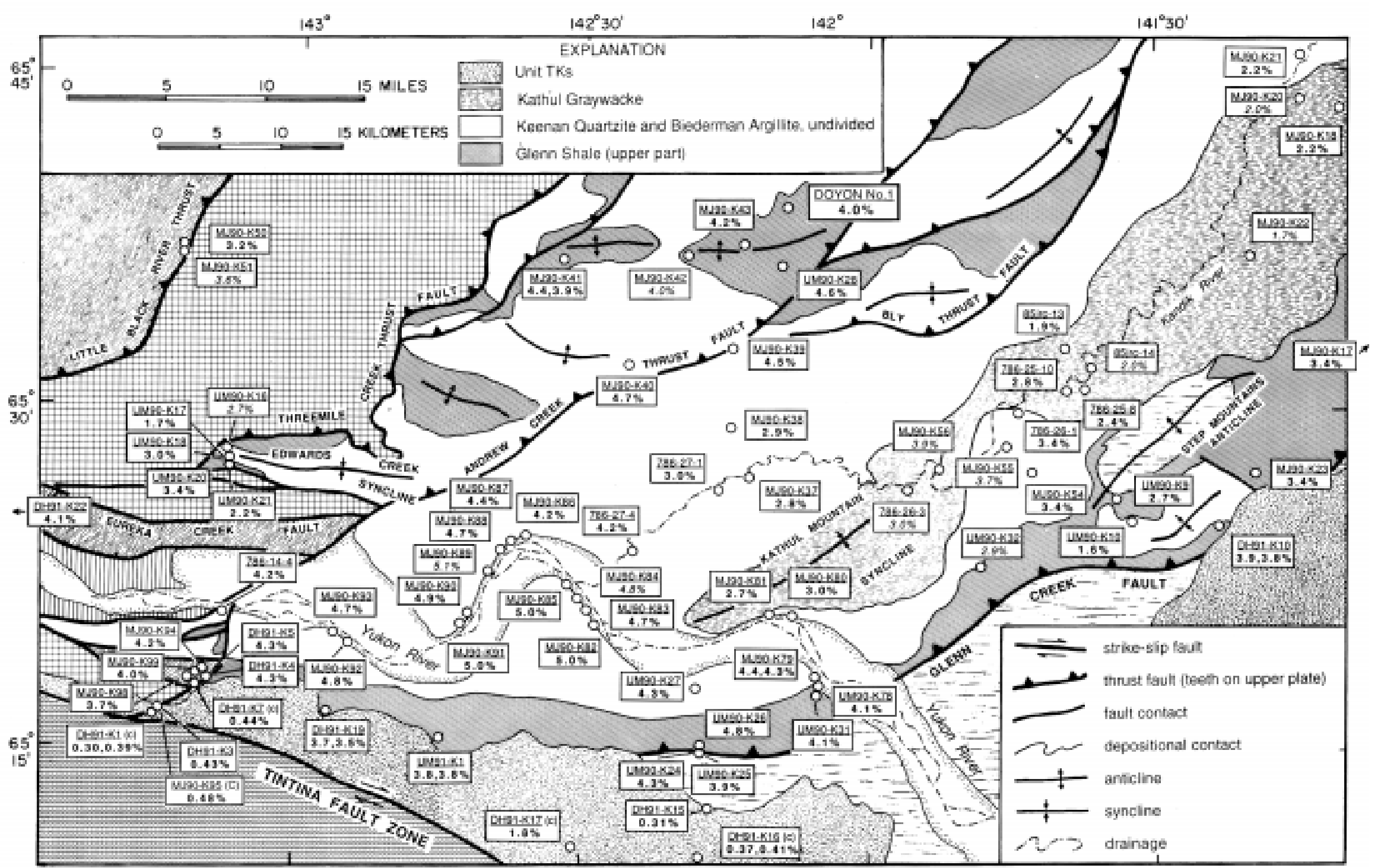

Figure 7. Simplified map of Kandik River and related suspect terranes of Eureka suture zone, plus unit TKs of Brabb and Churkin (1969), with sample localities and values of mean random vitrinite reflectance ( $R$, in percent). Geologic base modified from Brabb and Churkin (1969) and Dover and Miyaoka (1988). Multiple $R_{m}$ values correspond to localities from which multiple samples were collected and analyzed. Numbers in italic
W.23 Siven Dome terrane

Takoma Butll terrane

2-7. Paleozoic strata of Step Mountains and Tatonduk Bet correspond to specimens for which organic matter is insufficient to yield statistically reliable results (number of measured particles per specimen $=10$ to 20 ). A “(c)" next to sample number indicates coal or wood-fragment specimen. See table 1 for additional statistical information. Banks of Yukon River floodplain are highlighted with stippled pattern. Note position of Doyon No. 1 well in north-center of figure. 
Data from the Doyon No. 1 well are more difficult to interpret than most borehole profiles because several kilometers of structural overburden obviously were eroded between the time of peak regional metamorphism and the present. In addition, the possible effects of downhole cavings cannot be isolated. In spite of these problems, the thermalmaturity profile is consistent with paleoconditions of rapid heating, high geothermal gradients, and high fluid pressures. The presence of quartz veins with methane-bearing fluid inclusions elsewhere in the Kandik River terrane (Shelton and others, this volume) demonstrates that peak heating was accompanied by migration of both water and hydrocarbons along local fractures. Law and others (1989) have demonstrated that boundaries between linear segments in kinky $R_{m}$ profiles correspond to the approximate original boundaries between different fluid compositions (for example, water versus gas and water) and transient fluid-pressure regimes. It is well established, moreover, that overpressured conditions facilitate fault dislocation in thrust belts (Rubey and Hubbert, 1959), and large fluid volumes may be released after a slip event through zones of focused discharge (Sibson and others, 1975; Fyfe and Kerrich, 1985). Therefore, we speculate that the vertical thermal-maturity gradient retained within the Kandik River terrane may have been influenced by both thrust offsets and related pulses of fluid advection.

\section{GLENN CREEK FAULT ANOMALY}

When comparisons are made between the Kandik River terrane and most parts of the Tatonduk belt, there is a very large contrast in the level of thermal maturity (fig. 4). The average paleotemperature for the Kandik River terrane is $285^{\circ} \mathrm{C}$, whereas background paleotemperatures in the Tatonduk belt average only $130^{\circ} \mathrm{C}$. Obviously, this pattern is unusual in that most strata having high-rank thermal maturities to the northwest of the Glenn Creek Fault are Jurassic or Early Cretaceous in age, whereas low-rank rocks to the southeast are Proterozoic or Paleozoic. The paleothermal contrast is less dramatic, however, close to the terrane boundary. As described previously, there is an anomalous zone of higher thermal maturity within the footwall of the Glenn Creek Fault, as defined mostly by data from the Nation River Formation. The anomaly dissipates to background levels of less than 1.0 percent $R_{m}$ within about $15 \mathrm{~km}$ of the fault trace (fig. 5). Estimates of paleotemperature for the footwall anomaly range from $165^{\circ} \mathrm{C}$ to $265^{\circ} \mathrm{C}$, with values increasing toward the fault (fig. 6).

If one assumes a geothermal gradient of $30^{\circ} \mathrm{C} / \mathrm{km}$ at the time of peak thermal maturation within the Tatonduk belt (relatively common for normal continental crust), together with an average surface temperature of $20^{\circ} \mathrm{C}$, then roughly 5 to $8 \mathrm{~km}$ of depositional overburden would be required to produce the range of burial temperatures cited above. These overburden values, however, are greater than the sum total of maximum formational thicknesses as measured from the base of the Nation River Formation through the Kathul Graywacke (Brabb and Churkin, 1969). Additional overburden could be assigned to unit TKs, but there is a major angular unconformity separating this cover sequence from strata of the Tatonduk belt, and in most places the gap in thermal maturity across the unconformity is appreciable (fig. 5). In addition, spatial patterns of thermal maturity within the Glenn Creek Fault Zone anomaly are strongly discordant to those of the cover sequence, an observation which further demonstrates that the thermal anomaly formed before the unconformity at the base of unit TKs was produced.

The quandary of insufficient stratigraphic overburden within the Tatonduk belt is compounded by the lack of evidence for deposition of a thick Mesozoic section anywhere

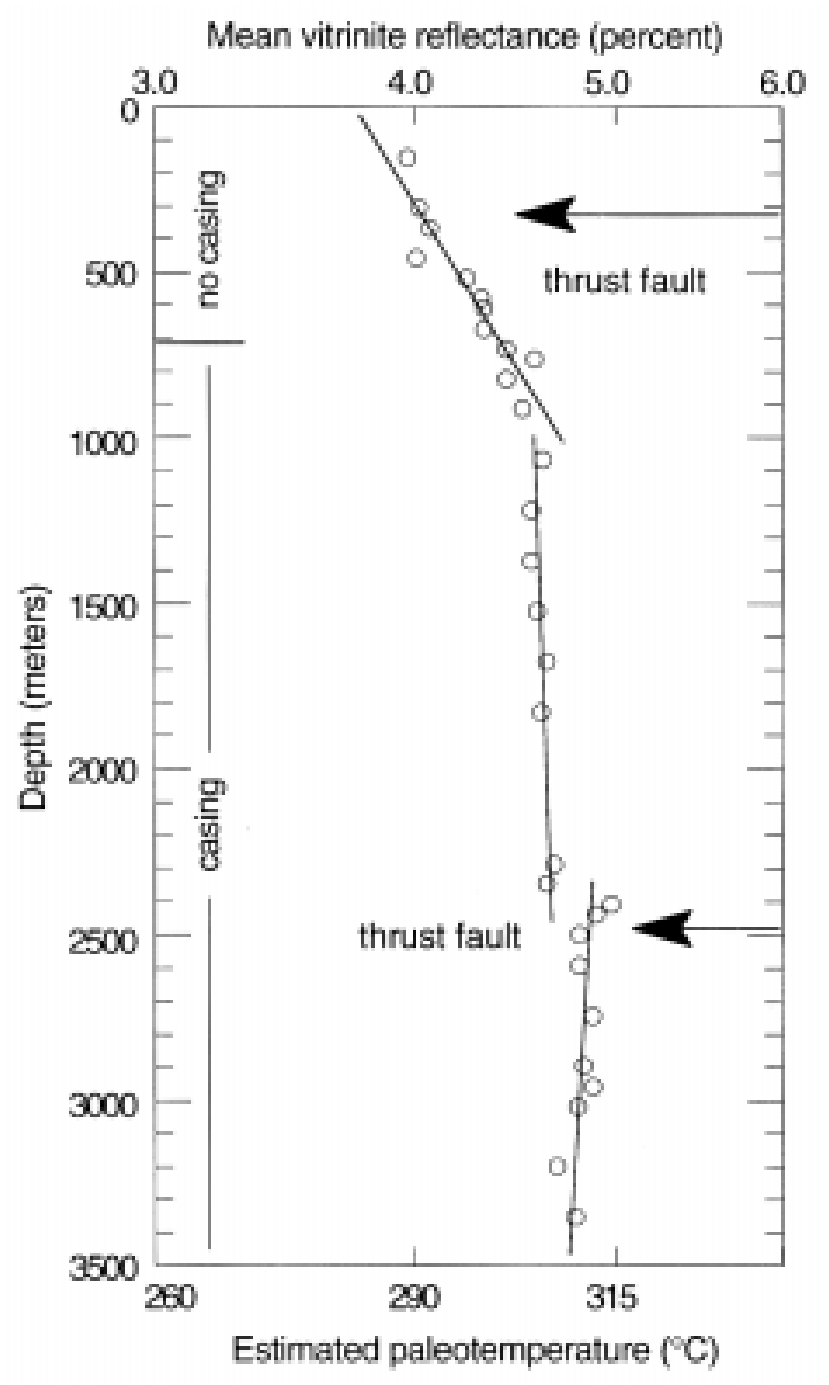

Figure 8. Vertical profile of mean random vitrinite reflectance $\left(R_{m}\right.$, in percent) and corresponding paleotemperature estimates $\left({ }^{\circ} \mathrm{C}\right)$ for the Doyon No. 1 borehole, following regression equation of Barker (1988). See figure 7 for location of borehole. 
southeast of the Glenn Creek Fault. Hypothetically, a timestratigraphic equivalent of the entire Kandik Group may have been deposited, and then removed completely by erosion, but this scenario seems contrived. Naturally, one might be able to bring the overburden and depth constraints into harmony by increasing the geothermal gradient to a higher value (for example, $\left.45^{\circ} \mathrm{C} / \mathrm{km}\right)$. By doing so, the average background paleotemperature for the Nation River Formation $\left(130^{\circ} \mathrm{C}\right)$ could then be generated by overburden corresponding to the stratigraphic thickness from the middle part of the Nation River Formation through the lower part (Middle and Upper Triassic) of the Glenn Shale (approximately $2500 \mathrm{~m}$ ). This adjustment in thermal conditions does not, however, help explain the restricted spatial distribution of the higher $R_{m}$ values. Finally, one might argue that the fault-zone anomaly was caused by advection of warm fluids, as discussed within the context of several comparable orogenic belts (for example, Bethke and Marshak, 1990; Deming and others, 1990; Deming, 1992; Ge and Garvin, 1992). However, we found no field evidence for focused fluid flow within the footwall (for example, zones of brecciation or unusually intense veining), and our analyses of existing veins showed that fluids moving through the Kandik River terrane differed chemically and thermally from those of the Tatonduk belt (Shelton and others, this volume). Consequently, we conclude that tectonic dislocation and conductive heat transfer across the fault were responsible for the footwall anomaly.

\section{STEP MOUNTAINS}

The Step Mountains region (fig. 1) is enigmatic in almost all respects, and the terrane designation for these rocks remains in dispute (Howell and others, 1992). Except for the Eureka suture zone farther to the west (Churkin and others, 1982), the Step Mountains contain the only pre-Mesozoic strata northwest of the Glenn Creek Fault Zone. The identification of badly altered (reworked?) Devonian spores has reinforced the inference of Brabb and Churkin (1969) that chert-pebble conglomerates in the core of the Step Mountains belong to the Nation River Formation (Miyaoka, 1990). Plant stems from siliceous shales on the flanks of the Step Mountains antiform are not age diagnostic, but these shales have been correlated with the Ford Lake Shale (Upper Devonian to Upper Mississippian) on the basis of lithologic similarities and stratigraphic position. Lenses of fossiliferous limestone within the Step Conglomerate (type section) are the only well-dated rocks; these bioclastic carbonate rocks are unequivocally Early Permian in age and coeval with the Tahkandit Limestone, which crops out to the south of the Glenn Creek Fault within the Tatonduk belt (Brabb, 1969; Brabb and Grant, 1971).

Several structural interpretations have been proposed for the Step Mountains region. The most straightforward scenario involves a faulted anticline with little or no horizontal displacement of the Paleozoic core relative to the Mesozoic rocks of the Glenn Shale and the Kandik Group (Brabb and Churkin, 1969; Dover and Miyaoka, 1988; Dover, 1992). Alternatively, the Paleozoic core may represent a window into the Tatonduk belt, with footwall strata exposed by erosion through a folded Glenn Creek Thrust Fault (Laughland and others, 1990). Finally, Howell and others (1992) speculated that the Devonian(?) to Permian strata at Step Mountains could be a displaced part of a Paleozoic basement complex above which the upper part of the Glenn Shale and the Kandik Group originally accumulated; analogous strata of Paleozoic age crop out to the west within the Eureka suture zone (that is, the Takoma Bluff and (or) Slaven Dome terranes of Churkin and others, 1982). According to this interpretation, the Step Mountains could be autochthonous with respect to the Kandik River terrane, but allochthonous with respect to the Tatonduk belt.

Unfortunately, only two reliable samples of both the Ford Lake Shale and the Nation River Formation were obtained from the structural core of the Step Mountains; these specimens produced $R_{m}$ values of 2.5 to 3.9 percent (table 1; fig. 9). Several additional samples of siliceous shale (lean in vitrinite) yielded values of 2.0 to 2.8 percent $R_{m}$ (fig. 9). Overall, the spatial pattern in organic metamorphism is very erratic and much more complicated than one might expect with a simple anticline. Specifically, the core of the fold is not consistently higher in thermal maturity than the flanks. Moreover, the level of thermal maturity within the Paleozoic core is lower than average for the surrounding Kandik River terrane, yet higher than the level displayed throughout most of the Tatonduk belt to the south. In general, CI data from uncleaved samples of the Ford Lake Shale at Step Mountains fall within the anchizone, a fact which is in accordance with values from the Biederman Argillite and upper part of the Glenn Shale (Underwood and others, 1992).

In summary, the existing thermal-maturity data, by themselves, are insufficient to resolve the conflicting structural hypotheses for the Step Mountains. Higher $R_{m}$ and lower CI values could be the results of nappe transport from the west, anticlinal exposure of autochthonous Paleozoic basement to the Kandik River terrane, or structural burial of the Tatonduk belt beneath the Glenn Creek fault prior to the formation of a fenster. On the other hand, isotopic and fluid-inclusion anomalies displayed by veins obtained from the Step Mountains have led Shelton and others (this volume) to conclude that the locality was affected by a unique set of fluid-rock interactions (high-salinity fluid and high $\delta^{18} \mathrm{O}$ ). We suggest, therefore, that the hydrothermal anomaly was associated with transient and localized fluid migration during the final stages of thrust emplacement, either along the main terrane boundary (Glenn Creek Fault) or along the base of a smaller nappe within the Kandik River terrane.

\section{SLAVEN DOME, WOODCHOPPER CANYON, AND TACOMA BLUFF TERRANES}

Three rock units deserve specific mention, even though data from them are relatively sparse. Unit Pza of Brabb and Churkin (1969) occurs within the western part of the study area (that is, within the Slaven Dome terrane of Churkin and others, 1982). The original stratigraphic position of these poorly dated argillites remains uncertain, as all contacts with 
adjacent formations have been mapped as faults (Brabb and Churkin, 1969; Dover and Miyaoka, 1988). Values of mean vitrinite reflectance for these rocks range from 3.2 to 4.3 percent (fig. 7), and paleotemperature estimates are $270^{\circ}$ to $300^{\circ} \mathrm{C}$ (fig. 4). Illite-crystallinity values for unit Pza are uniformly low $\left(0.40\right.$ and $\left.0.22 \Delta^{\circ} 2 \theta\right)$, indicating anchizone to epizone conditions of incipient metamorphism (Underwood and others, 1992). The growth of well-crystalline mica is consistent with the phyllitic appearance of hand specimens, and this observation supports the hypothesis that assigns unit Pza to the depositional basement of the Kandik River terrane (Howell and others, 1992). One shale sample from the Woodchopper
Canyon terrane yielded an $R_{m}$ value of 4.1 percent $\left(295^{\circ} \mathrm{C}\right)$. Finally, one marginally lean sample $\left(R_{m}=2.7\right.$ percent) was obtained from the Step Conglomerate (Tacoma Bluff terrane) near the western edge of the Edwards Creek syncline (fig. 7). Overall, thermal-maturity data from the Eureka suture zone are similar to those of the Kandik River terrane (fig. 4).

In addition to similarities in paleotemperature, isotope data from calcite veins in the Woodchopper Canyon terrane closely match results from the Kandik River terrane. This analytical result indicates that the two domains probably had been juxtaposed prior to the peak heating and fluid migration events that were responsible for vein precipitation (Shelton

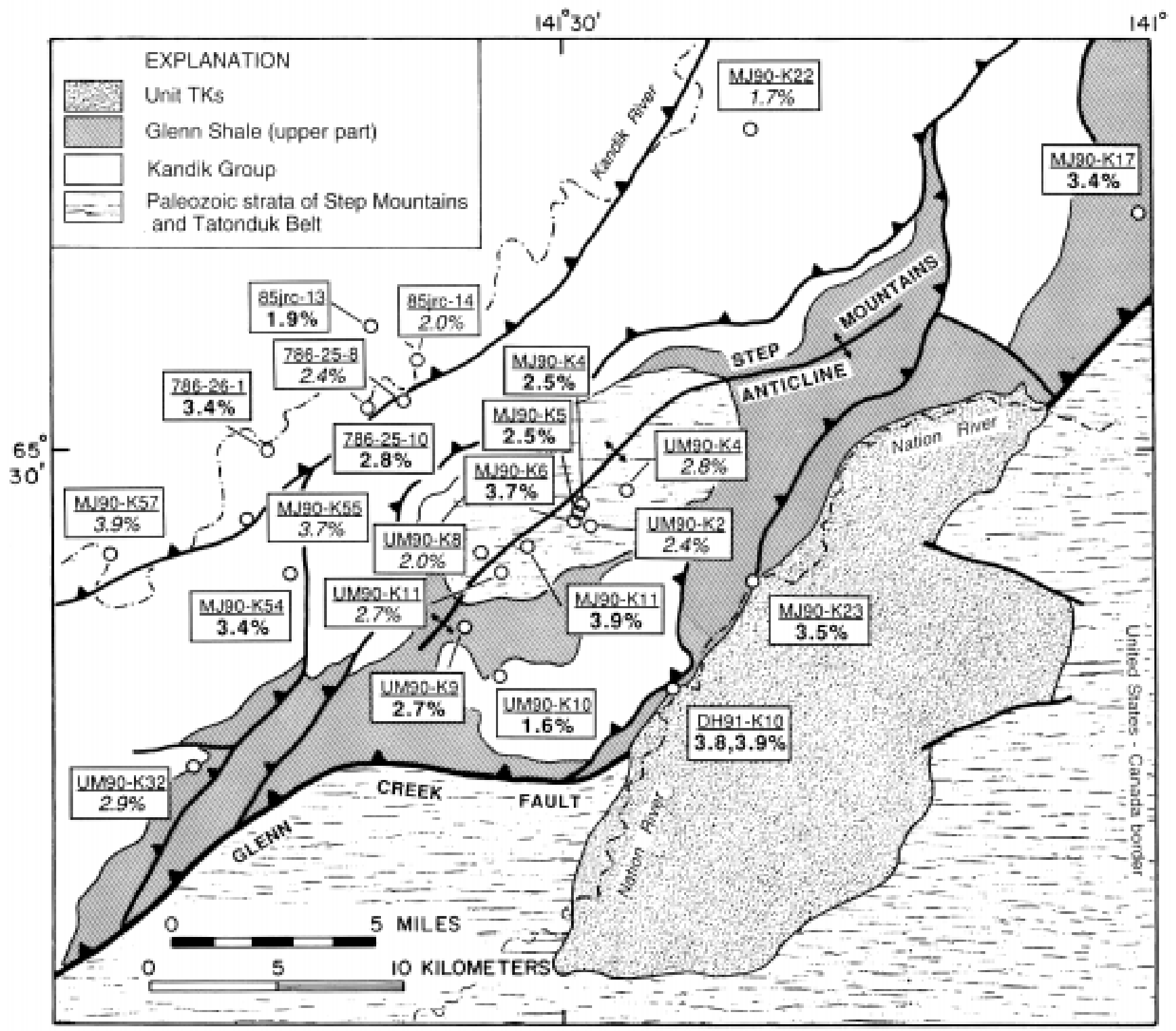

Figure 9. Simplified geologic map of Step Mountains region, showing sample localities and values of mean random vitrinite reflectance $\left(R_{m}\right.$, in percent). Geologic base modified from Dover and Miyaoka (1988). Numbers in italic correspond to specimens for which organic matter is insufficient to yield statistically reliable results (number of measured particles per specimen=10 to 20). Multiple $R_{m}$ values correspond to localities from which multiple samples were collected and analyzed. TKs, geologic unit TKs of Brabb and Churkin (1969). 
and others, 1992). A limited amount of additional data from the Slaven Dome terrane indicates likewise (Shelton and others, this volume). We note here that most of the faults that mark terrane boundaries within the Eureka suture zone are oriented east-west at an oblique angle to the structural grain of the Kandik thrust belt. Accordingly, it seems likely that the Woodchopper Canyon, Kandik River, Tacoma Bluff, and Slaven Dome terranes were amalgamated prior to the regional peak heating event, then transported together from the west.

\section{UNIT TKs}

Poorly indurated and mildly deformed alluvial and fluvial deposits of unit TKs crop out within two major zones: (1) adjacent to the northwest-striking Tintina Fault (fig. 7) and (2) within a smaller east-dipping homocline that we refer to as the Waterfall Creek section (fig. 5). The Tintina Fault section of unit TKs contains several northeast-trending megascopic folds. Both outcrop belts of unit TKs cover segments of the Glenn Creek terrane boundary (fig. 1). Most of the plant fossils and palynomorphs fail to provide precise ages, but deposition of unit TKs apparently began during the Late Cretaceous and extended into latest Eocene or Oligocene time (Dover and Miyaoka, 1988; Miyaoka, 1990). Unit TKs is important for two reasons: (1) the synorogenic to postorogenic deposits unconformably overlie terranes on both sides of the Glenn Creek Fault and (2) thermal maturity data can be used to place constraints on the amount of post-Albian overburden, as well as post-Albian geothermal conditions throughout the region.

Mean vitrinite-reflectance data from coal specimens, isolated wood fragments, and dispersed organic matter from mudstones of unit TKs are consistently low (fig. 4). Mean vitrinitereflectance values range from 0.22 percent (surface temperature and very little erosion) to 1.76 percent; the mean value for unit TKs is 0.50 percent $\left(75^{\circ} \mathrm{C}\right)$. We suspect that the single anomalously high value at site DH91-K17 (fig. 7) is due to sampling of an isolated fragment of inert organic matter (charcoal) rather than true coal. It is well known in coal petrology that inertinites produce significantly higher reflectance values than vitrinites, particularly at low coal ranks (Stach and others, 1982). Except for this spurious datum, spatial patterns within the main outcrop belt of unit TKs are fairly orderly. A gentle warping of paleoisothermal surfaces (fig. 6) coincides with the occurrences of northeast-trending synclines and anticlines within unit TKs (Brabb and Churkin, 1969; Dover and Miyaoka, 1988). Values of CI, on the other hand, are extremely erratic and inconsistent, ranging from $0.26 \Delta^{\circ} 2 \theta$ (anchizone-epizone boundary) to $0.68 \Delta^{\circ} 2 \theta$ (Underwood and others, 1992). Clearly, most of the illite and relatively coarse crystals of K-mica incorporated into these mudstones are detrital in origin, rather than a product of diagenetic alteration of the host rocks.

Brabb and Churkin (1969) estimated the thickness of unit TKs to be at least 3,000 ft ( 915 m). We suspect that this estimate is much too low, on the basis of the documented range of reliable paleotemperatures (surface temperature to $130^{\circ} \mathrm{C}$ ). Using our measured bedding attitudes, together with those of Brabb and Churkin (1969) and Dover (1992), we calculated a minimum stratigraphic thickness of 4,200 $\mathrm{m}$ for the east-dipping homocline transected by Waterfall Creek (fig. 5). Samples collected from a fold limb along Washington Creek (fig. 7) provide enough information to calculate the paleogeothermal gradient. Paleotemperatures along this limb change from surface values $\left(0.24\right.$ percent $\left.R_{m}\right)$ to $55^{\circ} \mathrm{C}\left(0.41\right.$ percent $\left.R_{m}\right)$ over a stratigraphic thickness of approximately $3,000 \mathrm{~m}$. If the average middle Tertiary surface temperature is set at $10^{\circ} \mathrm{C}$, then these data translate to a temperature-depth gradient of only $\sim 15^{\circ} \mathrm{C} /$ $\mathrm{km}$. With this relatively low gradient, the average paleotemperature of $75^{\circ} \mathrm{C}$ would correspond to an average burial depth of 4,300 m, which is consistent with the calculated thickness of the Waterfall Creek section.

\section{DISCUSSION AND MODELING}

\section{EARLY CRETACEOUS BURIAL DEPTHS AND GEOTHERMAL GRADIENTS}

Because of the intensity of internal deformation within the Kandik River terrane, we have no direct means of arriving at reliable estimates of paleodepth at the time of peak heating. Estimates of maximum pressure, however, can be derived from illite/mica- $b_{0}$ data. Figure 10 shows that most illite/mica- $b_{0}$ values range from 9.000 to $9.020 \AA$; the mean value for 45 specimens is $9.012 \AA$, and there are no meaningful differences among the various tectonostratigraphic domains. According to Guidotti and Sassi (1986), this range of values is associated with the lower part of the intermediatepressure facies series for low-grade metapelites. Similar results have been obtained from comparable mountain belts, such as the Appalachians of northern New Hampshire (Sassi and Scolari, 1974) and the Swiss Alps (Padan and others, 1982). Thus, there is no evidence to suggest abnormally high burial pressures or low geothermal gradients at the time of peak heating.

As discussed previously, there are several problems associated with precise application of $b_{0}$ geobarometry, particularly within regions of incipient metamorphism. Of the formations analyzed, vitrinite-reflectance data show that only the Kandik River and Slaven Dome terranes (and perhaps Step Mountains) reached burial temperatures high enough to have resulted in mica crystallization. For the other strata (especially unit TKs) the phyllosilicates in question are clearly detrital in origin and thus provide no information concerning in situ burial conditions. One anomalous sample (UM90-K24) plots within the confines of the high-pressure facies series; this sample is intriguing because it was obtained from the upper part of the Glenn Shale in the immediate vicinity of the Glenn Creek Fault (fig. 7). However, we do not believe the 
single datum is sufficient to establish a cause and effect link between fault dislocation and illite/mica crystallization.

The empirical compilation of Guidotti and Sassi (1986) indicates that for a temperature maximum of $315^{\circ} \mathrm{C}, b_{0}$ values of approximately $9.010 \AA$ should be produced at pressures of approximately $2.25 \mathrm{kbar}$. Assuming lithostatic conditions and an average bulk density of $2.65 \mathrm{~g} / \mathrm{cm}^{3}$, this maximum pressure would be reached at a depth of roughly $8.5 \mathrm{~km}$. We set the mean annual surface temperature at the time of peak heating at $20^{\circ} \mathrm{C}$, which is higher than the assumed middle Tertiary value of $10^{\circ} \mathrm{C}$ used in the preceding discussion of unit TKs; this choice is based on paleomagnetic evidence for absolute motion of North America toward the northwest during the Jurassic and Cretaceous and associated changes in climate (see, for example, Engebretson and others, 1985). Accordingly, the late Early Cretaceous geothermal gradient (maximum temperature divided by maximum depth) equates to approximately $35^{\circ} \mathrm{C} / \mathrm{km}$. This gradient is best viewed as the lowest linear average to account for the highest formation temperatures because, even if the regional conductive heat flow had been constant (that is, no lateral flux, advection, or convection of hydrothermal fluids), normal changes in bulk thermal conductivity with depth (due to compaction, loss of pore water, and chemical diagenesis) will produce nonlinear profiles that increase in slope with depth.

A second method of estimating pressure at the time of quartz-carbonate vein precipitation has been outlined by

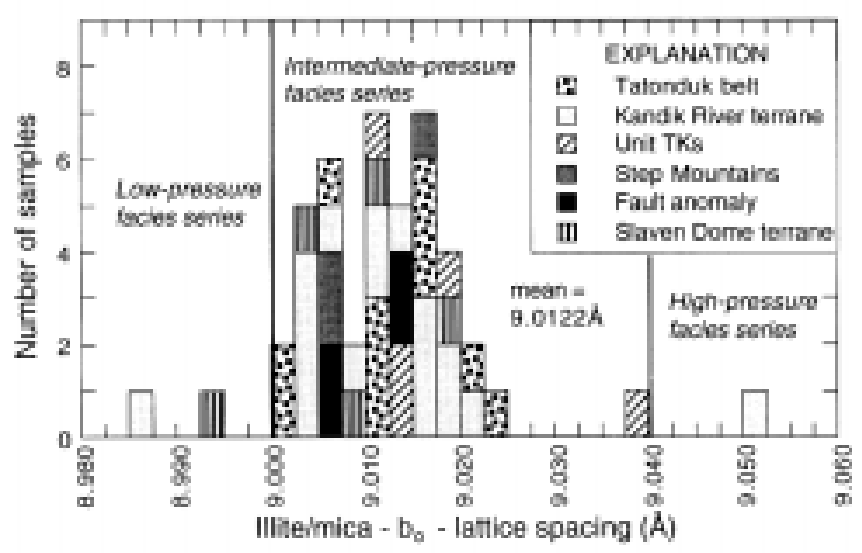

Figure 10. Histogram of illite/mica- $b_{0}$-lattice spacing ( $\AA$ ) for representative samples from Kandik study area. Mean value is 9.0122 $\AA$, and most data correspond to lower part of intermediate-pressure facies series, as defined by Guidotti and Sassi (1986). At a temperature of $\sim 300^{\circ} \mathrm{C}$, this range of phengite substitution in muscovite-celadonite solid-solution series should occur at a pressure of $\sim 2.25 \mathrm{kbar}$. Data for Slaven Dome terrane are from geologic unit Pza of Brabb and Churkin (1969). TKs, geologic unit TKs of Brabb and Churkin (1969).
Shelton and others (this volume). Differences between temperatures from oxygen isotope fractionations and fluid-inclusion homogenization temperatures (that is, the "pressure correction" to $T_{h}$ values) indicate that fluid pressures were between 500 and 800 bars at the time of vein precipitation. Assuming a hydrostatic pressure regime, these data are consistent with burial depths of approximately 5 to $8 \mathrm{~km}$ and linear geothermal gradients of approximately 35 to $60^{\circ} \mathrm{C} / \mathrm{km}$. Pressure estimates for methane-bearing fluid inclusions, which were trapped locally along healed fractures in a few of the Kandik River quartz veins, range from 800 to 1,500 bars (Shelton and others, this volume). It is conceivable that the Kandik River terrane experienced a significant increase in hydrostatic pressure because of structural thickening prior to methane entrapment ( 8 to $15 \mathrm{~km}$, assuming pure hydrostatic conditions). However, a depth increase of nearly twofold seems excessive, and there is no evidence from illite/mica $b_{0}$ data to support the idea of a concomitant increase in lithostatic pressure (up to the required 2,100 to 3,900 bars at 8 to 15 $\mathrm{km})$. We favor, instead, a scenario in which excess pore-fluid pressures developed locally during deformation of the Kandik River terrane. If fluid pressures approached lithostatic values, for example, then the depth range during methane entrapment would rise to between 3.1 and $5.8 \mathrm{~km}$, and the linear geothermal gradient would increase to a value between $50^{\circ}$ and $95^{\circ} \mathrm{C} / \mathrm{km}$. Naturally, a combination of structural thickening and development of fluid pressures somewhere between the hydrostatic and lithostatic limits would result in values closer to the range cited above $\left(35^{\circ}\right.$ to $\left.60^{\circ} \mathrm{C} / \mathrm{km}\right)$.

\section{HEATING, COOLING, AND UPLIFT HISTORY}

The evidence for rapid uplift and erosion of the Kandik River terrane (and related units within the Eureka suture zone) is largely indirect. Imprecise fossil control and lithologic correlations collectively indicate that the basal sediments of unit TKs may have been deposited near the Albian-Cenomanian time boundary. If these inferences are correct, then the elapsed time between deposition of the Kathul Graywacke (Albian?) and deposition above the angular unconformity at the base of unit TKs could not be more than about 10 million years. This hiatus obviously was long enough, however, to accommodate several major events within the Kandik River terranefolding and cleavage formation, fluid migration and vein precipitation, internal thrust imbrication, peak heating and organic metamorphism, southeast-directed transport and eventual suturing to the Tatonduk belt along the Glenn Creek Fault, and a substantial decay in the regional heat flux (fig. 11).

To establish the absolute timing of cooling within the Kandik River terrane, fission-track analyses were completed on detrital apatites from the uppermost part of the Biederman Argillite and the Kathul Graywacke; specimens were collected from a single well-exposed section, where the Kathul Mountain syncline intersects the Yukon River (site MJ90-K81, fig. 
7). The amount of relief associated with this section is not sufficient to yield consistent changes in cooling ages as a function of present-day elevation. Of the four analyses completed, three provide statistically reliable pooled ages of $96.3 \pm 9.4$, 85.7 \pm 7.9 , and 80.1 $\pm 6.3 \mathrm{Ma}$. Chi-squared probabilities that these pooled ages represent data from single, normally distributed, populations are $\mathrm{P}\left(\chi^{2}\right)=21$ to 80 percent (table 2 ). The fourth sample yielded an unreliable pooled age of 57.6 \pm 7.6 $\mathrm{Ma}$ (chi-squared probability of $\mathrm{P}\left(\chi^{2}\right)=0.5$ percent) and a mean age of $83.1 \pm 29.5 \mathrm{Ma}$ (table 2 ). All of these dates are younger than the apparent age of deposition of the Kathul Graywacke ( 120 to $110 \mathrm{Ma}$ ), and so the fission-track ages must repre- sent an episode of cooling that occurred after partial to total thermal resetting of the detrital apatite grains.

Annealing of inherited fission-tracks can be affected by a variety of factors, such as crystal chemistry, heating rate, and heating duration (Green and others, 1985). For a heating duration on the order of $10^{6}$ years the temperature required for annealing to begin is approximately $70^{\circ}$ to $80^{\circ} \mathrm{C}$, and total annealing occurs at approximately $125^{\circ} \mathrm{C}$ (Green and others, 1989; Naeser and others, 1989). The partial annealing zone (PAZ) corresponds to temperatures between these two limits. Vitrinite-reflectance data show that paleotemperatures for the Kathul Mountain section reached approximately $250^{\circ} \mathrm{C}$

\section{THERMOTECTONIC HISTORY OF THE KANDIK REGION}

A

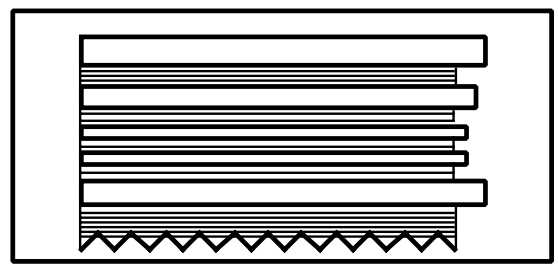

B

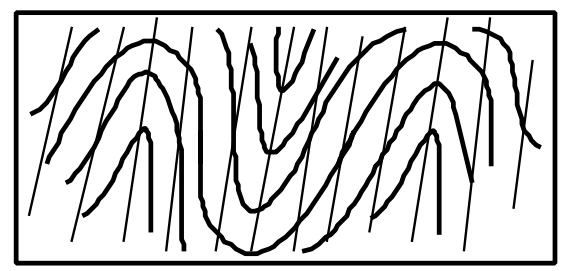

C

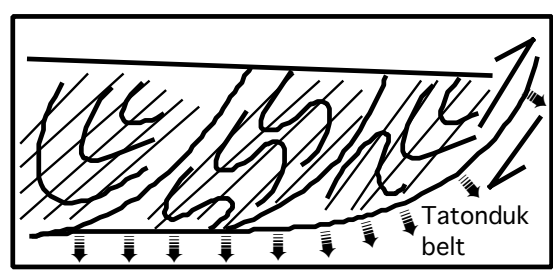

D

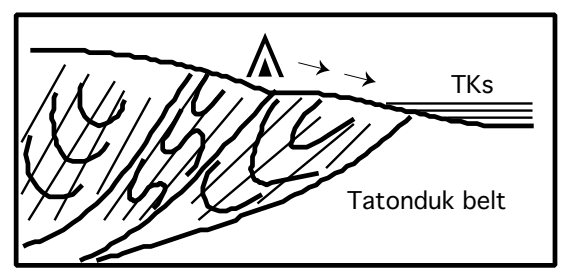

E

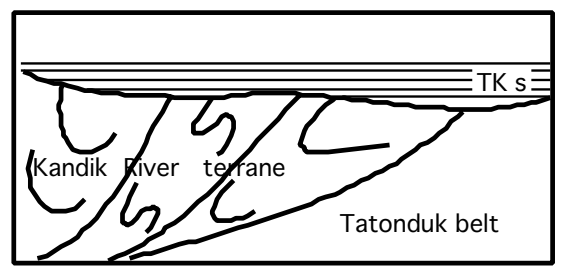

140-110 Ma (Early Cretaceous)

Deposition of Kandik Group deep-marine turbidites

\section{0-100 Ma (early Albian)}

Peak heating event under high geothermal gradients; organic metamorphism; folding, cleavage, and dehydration; veins form at 500-800 bars (near hydrostatic pressure).

\section{0-95 Ma (Albian to Cenomanian)}

Uplift and cooling begins; initiation of terrane amalgamation via Glenn Creek fault; structural thickening by imbrication; methane-bearing inclusions occur at 800-1,500 bars (lithostatic pressure); development of footwall aureole by conduction across fault (dashed arrows).

\section{5-75 Ma (Cenomanian to Campanian)}

Continued uplift, cooling, and erosion; syntectonic deposition of basal sediments of unit TKs of Brabb and Churkin (1969).

\section{5-30 Ma (Maastrichtian to Oligocene)}

Progradation of unit TKs of Brabb and Churkin (1969); fluvial/alluvial deposition; minor late-stage deformation

Figure 11. Schematic cartoons to illustrate thermotectonic history of Kandik region, east-central Alaska. See text for discussion. TKs, geologic unit TKs of Brabb and Churkin (1969). 
(fig. 6), well in excess of the PAZ, and except for a few anomalous apatite grains, statistical distributions of single crystal ages confirm that total annealing did take place. When rocks such as these are heated well above the total annealing temperature and subsequently cooled, the fission-track age can be interpreted as a cooling age, representing the time the sample cooled through a closure temperature. The closure temperature for fission tracks in apatite is about $100^{\circ} \mathrm{C}$. Thus, the pooled ages of 80 to $96 \mathrm{Ma}$ can be regarded as the approximate times of cooling through the $100^{\circ} \mathrm{C}$ isotherm.

Measurements of fission-track length also provide important information about thermal history (Gleadow and others, 1983; Green and others, 1989). Track-length measurements for the sandstones of the Biederman Argillite and Kathul Graywacke resulted in relatively large means of 13.95 to $14.12 \mu \mathrm{m}$, and the corresponding standard deviations range from 1.40 to 2.34 (table 2). These track lengths are close to the maximum values of $15 \mu \mathrm{m}$ for unannealed primary tracks (Green and others, 1989). Track-length distributions of this type are produced only when rocks cool rapidly through the PAZ (Gleadow, Duddy, Green, and Hegarty, 1986; Gleadow, Duddy, Green, and Lovering, 1986; Dumitru, 1989; O'Sullivan and others, 1993). Slower cooling rates, with residence times in the PAZ of more than 3 to $5 \mathrm{~m}$.y., will produce a component of shorter tracks (formed early in the cooling history and partially annealed), and standard deviations about the mean track length will be larger. Our data show that partial annealing of the new fission tracks did not occur within the Kandik Group. Instead, the effects of Albian thermal resetting decayed rapidly during Cenomanian to Campanian time, and the Lower Cretaceous sandstones were not subjected to any subsequent heating events above about $70^{\circ} \mathrm{C}$.

If the apatite fission-track ages are accurate indicators of cooling through the $100^{\circ} \mathrm{C}$ isotherm, then peak heating must have occurred almost immediately after deposition of the uppermost part of the Kandik Group. The narrow time window between deposition ( 120 to 110 Ma) and peak heating of the upper parts of the Kandik Group is not compatible with the types of heating rates responsible for burial diagenesis within mature rifted margins and subsiding basins such as the Gulf Coast of the United States. At those rates, which are on the order of $5^{\circ} \mathrm{C} / 10^{6} \mathrm{yr}$. (Sweeney and Burnham, 1990), it would have taken approximately $60 \mathrm{~m}$.y. for the Kandik Group to have reached maximum levels of thermal maturity. In comparison, heating rates within active geothermal fields are on the order of $1^{\circ} \mathrm{C} / 10^{3} \mathrm{yr}$. Additional analytical techniques are required to establish the absolute timing of peak heating with greater precision (for example, ${ }^{40} \mathrm{Ar} /{ }^{39} \mathrm{Ar}$ dating of cleavage-forming mica). In the absence of such data, our best estimate for the culmination of the thermal overprint is at approximately 110 to $105 \mathrm{Ma}$, which corresponds to an early to middle Albian event. Accordingly, an average heating rate of at least $35^{\circ}$ to $40^{\circ} \mathrm{C} / \mathrm{m}$.y. would be required to achieve maximum burial temperatures of $300^{\circ}$ to $315^{\circ} \mathrm{C}$.

It seems clear that the Kandik River terrane not only was deformed and thermally overprinted at a rapid rate during the early to middle Albian, it also cooled fairly quickly beginning in middle to late Albian time (fig. 11). If we use the oldest apatite fission-track age ( $96 \mathrm{Ma})$ as an indication of the first rocks to cool from a peak temperature of $250^{\circ} \mathrm{C}$ through the $100^{\circ} \mathrm{C}$ isotherm, then the age constraints translate to an average cooling rate of $15^{\circ} \mathrm{C} / \mathrm{m}$.y. This rate is consistent with our interpretations of fission-track-length distributions. The slowest cooling rate permitted by the data would be approximately $5^{\circ} \mathrm{C} / \mathrm{m} . \mathrm{y} .\left[\left(250^{\circ} \mathrm{C}-100^{\circ} \mathrm{C}\right) \prod(110 \mathrm{Ma}-80\right.$ $\mathrm{Ma})$. The asymmetry of heating and cooling P-T-t pathways (faster heating, slower cooling) is consistent with reconstructions of thermal history in other orogenic belts (for example, Thompson and England, 1984; Wintsch and others, 1992). Although regional cooling can occur solely because of a temporal decay in heat flow (for example, following an igneous intrusion or hydrothermal flux), it seems likely in this case that cooling progressed through the Campanian (84 to $74 \mathrm{Ma}$ ) and was accompanied by uplift and erosion of the Kandik River and related terranes (fig. 11). We base this interpretation on two observations: (1) the basal nonmarine deposits of unit TKs also began to accumulate during Late Cretaceous time and (2) the TKs alluvium appears to have been eroded, at least in part, from thrust nappes within the Kandik River and related terranes (Howell and others, 1992).

\section{MODELING OF THE GLENN CREEK FOOTWALL ANOMALY}

Laughland and others (1990) suggested that higher $R_{m}$ values near the Glenn Creek Fault were caused by heat conduction as a hot hanging wall (Kandik River terrane) was uplifted and thrust over the cooler footwall (Tatonduk belt). The southeastward termination of the paleothermal anomaly is related either to wedging out of the hanging wall (Laughland and others, 1990) or to a transition from a thrust ramp or associated fault-bend fold in the hanging wall to a flat in the hanging wall. As discussed by many workers (for example, Oxburgh and Turcotte, 1974; Brewer, 1981; Angevine and Turcotte, 1983; Furlong and Edman, 1984; Davy and Gillet, 1986; Shi and Wang, 1987; Karabinos and Ketcham, 1988), several parameters control the amount of heat transferred across a thrust fault. These factors include the thickness of the overthrust slab, geothermal gradient, thermal conductivities, prethrust temperature regimes within both thrust plates, displacement rate, and heating time. Although unique numerical solutions are not possible because of the large number of variables, Laughland and others (1990) tested several iterations of the Furlong and Edman (1984) nondimensional modeling technique and concluded that the Glenn Creek anomaly 


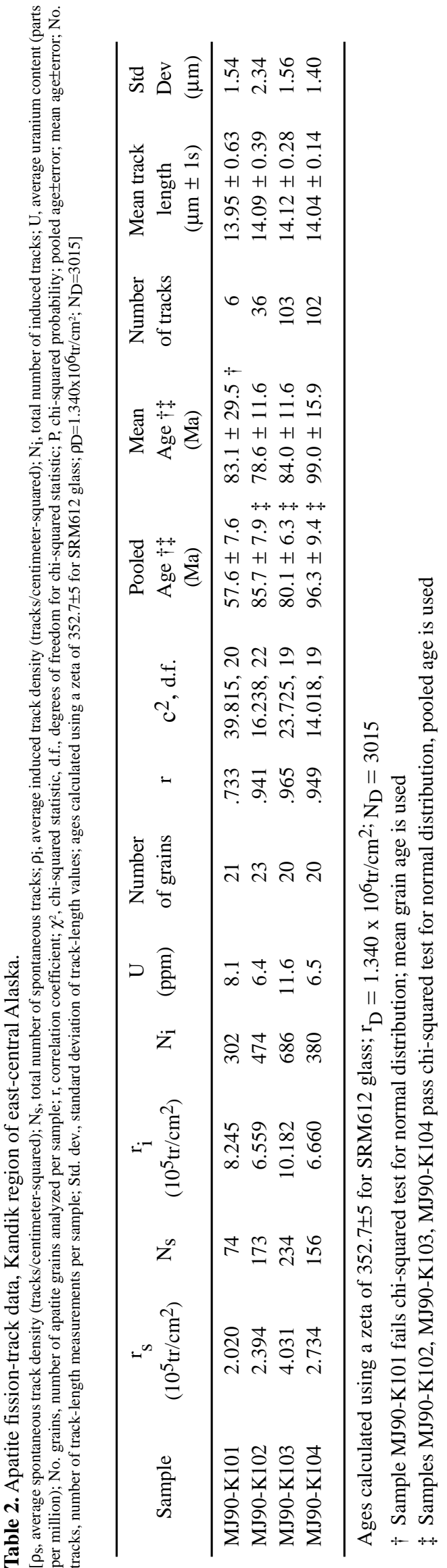

could have been generated by the following conditions: hanging wall $=3 \mathrm{~km}$ in thickness, geothermal gradient $=40^{\circ} \mathrm{C} / \mathrm{km}$, and heating time $=2$ m.y. (rapid uplift and cooling). Laughland and others (1990) likewise arrived at the limiting conditions to prevent resetting of $R_{m}$ values that had been inherited from prethrust depositional events. Our greatly expanded data set now allows refinement of some of the geometric and thermal conditions and revision of this simple model.

Maximum paleotemperatures from the upper part of the Glenn Shale near the base of the Kandik River hanging wall range from $290^{\circ}$ to $310^{\circ} \mathrm{C}$ (fig. 6). Regardless of the exact paleodepth and temperature prior to terrane amalgamation, $R_{m}$ values in the footwall near the present trace of the Glenn Creek Fault were reset during thrusting. We set the geothermal gradient within the Kandik River hanging wall at a value of $45^{\circ} \mathrm{C} / \mathrm{km}$, a median value consistant with fluid inclusion data. To account for a temperature of $290^{\circ} \mathrm{C}$ at the base of the hanging wall $\left(T_{b}\right)$, at the time of thrusting, the thrust sheet near the present trace of the fault would have to reach a thickness $(H)$ of $6 \mathrm{~km}$ (assuming a surface temperature of $\sim 20^{\circ} \mathrm{C}$ ). We also assume a rather brief thrust-heating event of $2 \mathrm{~m} . \mathrm{y}$. duration on the basis of apatite-fission-track evidence for Late Cretaceous uplift and cooling. Given these hypothetical conditions, the nondimensional value of heating time $(\tau)$ can be determined using the following equation:

$$
\tau=\kappa t \div H^{2}
$$

where $\kappa=$ thermal diffusivity (assumed value $=32 \mathrm{~m}^{2} / \mathrm{yr}$ ), $t$ $=$ duration of applied temperature maximum $\left(2 \times 10^{6} \mathrm{yr}\right)$, and $H=$ thickness of overthrust slab $(6,000 \mathrm{~m})$. Inputting the values from above yields a nondimensional time of $\sim 1.8$ (fig. 12).

$D *$ represents the nondimensional depth below the thrust surface scaled by the thickness of the thrust sheet, such that a $D^{*}$ value of +1 would be located one thrust-sheet thickness below the fault (fig. 12). Accordingly, at a depth $(X)$ of 2 km below a 6-km-thick Kandik River overthrust $(H)$, the $D^{*}$ value would be equal to $0.33 . T^{*}$ is the nondimensional temperature at a given depth scaled to the value of $T_{b}$. Figure 12 shows a modified version of the Furlong and Edman (1984) plot of $T^{*}$ versus $D^{*}$ for various values of $\tau$. We can use this diagram in reverse to help identify the conditions during faulting that would be required to produce the average temperature of $245^{\circ} \mathrm{C}$ within the footwall aureole. The $T^{*}$ value for this condition is equal to 0.84 , and the $245^{\circ} \mathrm{C}$ predicted temperature would occur at a depth of $2 \mathrm{~km}$ below the Glenn Creek Fault, 2 m.y. after thrust emplacement ( $\tau=1.8)$. We view this combination of geometric and thermal values as the ideal numerical solution, but the same temperature could be generated using several other reasonable combinations of $\tau$ and $D^{*}$ (table 3 ). For example, a $\tau$ value of 1 (heating time $=1.1$ m.y.) would push the corresponding subthrust depth down to $2,520 \mathrm{~m}\left(D^{*}=0.42\right)$, and a $\mathrm{t}$ value of 5 (heating time $=5.6 \mathrm{~m} . \mathrm{y}$.) would require a subthrust depth of only $600 \mathrm{~m}\left(D^{*}=0.1\right)$. Table 
3 shows several additional iterations for which geothermal gradients were changed to values of $30^{\circ} \mathrm{C} / \mathrm{km}$ and $60^{\circ} \mathrm{C} / \mathrm{km}$. Higher temperature gradients in the hanging wall necessitate extremely rapid unroofing, whereas lower gradients result in durations of heating and wedge thicknesses that appear to be excessive.

Laughland and others (1990) showed how several reasonable reductions in hanging-wall thickness toward the southeast, combined with changes in depth below the thrust surface, could lead to a limiting condition in which the value of $T^{*}$ becomes too small to reset $R_{m}$ values in the footwall. Given the revised data outlined above $(H=6,000 \mathrm{~m} ; t=2 \mathrm{~m} . \mathrm{y}$; $45^{\circ} \mathrm{C} / \mathrm{km}$ geothermal gradient), this exercise can be repeated. Four iterations are shown in table 4 . Included in this table are

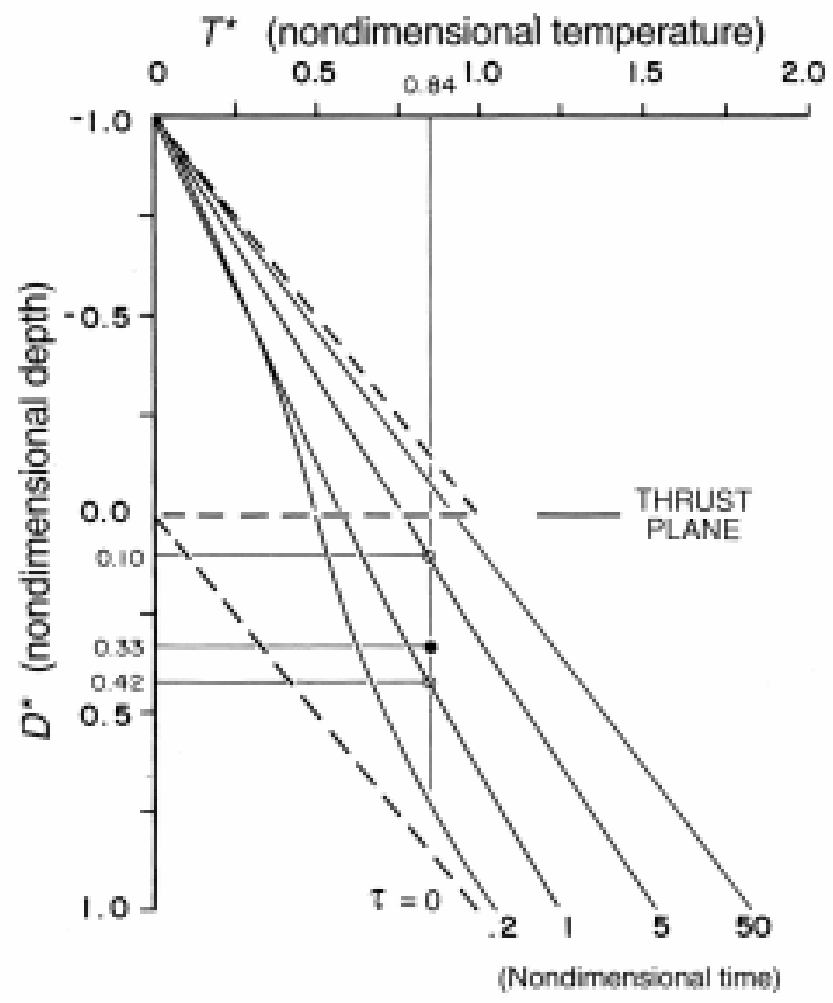

Figure 12. Graph of nondwimensional temperature $\left(T^{*}\right)$ and nondimensional depth $\left(D^{*}\right)$ for various values of nondimensional time $(\tau)$, as applied to thermal modeling of Glenn Creek Fault (modified from Furlong and Edman, 1984). Heavy dashed line represents thermal condition immediately after thrust emplacement $(\tau=0)$. A $T^{*}$ value of 0.84 corresponds to a basal hanging-wall temperature of $295^{\circ} \mathrm{C}$ and an average footwall temperature of $245^{\circ} \mathrm{C}$. Solid dot represents our preferred combination of parameters to generate a thrust fault aureole, with a hanging-wall thickness equal to $6 \mathrm{~km}$ and the average footwall temperature occurring $2 \mathrm{~km}$ below the Glenn Creek Fault $\left(D^{*}=0.33\right)$ approximately 2 m.y. after thrust emplacement. The $D^{*}$ values of 0.10 (subthrust-depth=600 m) and 0.42 (subthrust-depth $=2,520 \mathrm{~m}$ ) correspond to the same hangingwall conditions and heating times of approximately 5.6 m.y. and 1.1 m.y., respectively. See tables 3 and 4 for results of calculations using additional sets of hypothetical values for geometric and thermal parameters. calculations of the horizontal distance (to the southeast) relative to the reference position of the present Glenn Creek Fault trace. We assume an average fault dip of $10^{\circ}$ to allow for several flats and ramps, and with this angle, a 6-km-thick hanging wall would terminate $34 \mathrm{~km}$ to the southeast of the existing fault trace. For all iterations, at depths greater than the limiting value of $X$, temperatures would be high enough to reset $R_{m}$. From these examples, it follows that overthrust wedges with thicknesses of 4,000 m or more would increase ranks of organic metamorphism at all depths below the fault (that is, $X<0$ ). Conversely, for a wedge thickness of $3,000 \mathrm{~m}$, values would not be reset until a subthrust depth of $540 \mathrm{~m}$, and for a 2,000-m-thick thrust sheet, the limiting depth is 1,140 m. The case in which $H=3,000 \mathrm{~m}$ provides the best match with the empirical data base because the predicted lateral termination of the footwall aureole corresponds most closely to the actual horizontal distance between the present Glenn Creek Fault trace and the eastern boundary of higher thermal maturity along the Nation River (fig. 6).

Oxburgh and Turcotte (1974) first used the Peclet number to illustrate how faulting can alter geotherms in thrust belts. The expected change is from a steady-state linear temperature profile to a sawtooth geometry, followed by thermal relaxation (fig. 12). The Peclet number $(\mathrm{Pe})$ is a dimensionless ratio between the rate of heat advection during thrusting and the rate of heat conduction. The physical transfer of hotter rocks over colder rocks is considered to be one form of heat advection. By definition:

$$
P e=(V H) \div \kappa
$$

where $V=$ horizontal velocity of thrust emplacement $(\mathrm{m} / \mathrm{yr})$, $H=$ thickness of overriding thrust sheet $(\mathrm{m})$, and $\kappa=$ thermal diffusivity $\left(\mathrm{m}^{2} / \mathrm{yr}\right)$. Peclet numbers will be greater than 1 if heat is physically elevated by fault motion (advected) faster than it can be conducted out of the hanging wall; this condition will lead to perturbations of thermal structure within the footwall. If we assume, as above, a $\kappa$ value of $32 \mathrm{~m}^{2} / \mathrm{yr}$, a thrust-sheet thickness of $6,000 \mathrm{~m}$, and a rate of thrust movement of $0.03 \mathrm{~m} / \mathrm{yr}$, then the Peclet number is equal to approximately 5.6. The rate of emplacement would have to be slowed to $0.005 \mathrm{~m} / \mathrm{yr}$ to reduce $P e$ to 1 . Alternatively, a hypothetical thrust sheet could be thinned to approximately 1,000 $\mathrm{m}$ with the rate maintained at $0.03 \mathrm{~m} / \mathrm{yr}$; however, this would require substantial amounts of preslip erosion (and cooling) to bring high rank strata $\left(R_{m}>3.0\right.$ percent) close to the fault surface, and there is no geological evidence to support such a scenario.

The Peclet number, as defined above, is one dimensional. Because thrust transport is actually two dimensional within a given cross section, Karabinos (1988) and Endignoux and Wolf (1990) have modified the calculation by introducing the dip angle of the fault (q) into the equation; this allows determination of the vertical component of emplacement velocity. Two time constants then can be calculated: the time 
Table 3. Geometric and thermal conditions required to generate temperature of $245^{\circ} \mathrm{C}$ beneath the Glenn Creek Fault (assumed surface temperature $=20^{\circ} \mathrm{C}$ ).

$\left[H\right.$, thickness of overthrust sheet; $X$, depth below fault surface; $T^{*}$, nondimension temperature $\left(T \prod_{b} T_{b}\right.$, where $T=$ temperature at depth $=X$ and $T_{b}=$ temperature at base of hanging wall); $t$, heating time (m.y.); $\mathrm{t}$, nondimensional time $\left(\kappa t \div H^{2}\right.$, where $\kappa=$ thermal diffusivity); $D^{*}$, nondimensional depth $\left.(X \div H)\right]$

\begin{tabular}{|c|c|c|c|c|c|}
\hline$H(\mathrm{~m})$ & $X(\mathrm{~m})$ & $D^{*}$ & $T^{*}$ & $\tau$ & $t$ (m.y.) \\
\hline & \multicolumn{2}{|c|}{ Geothermal } & \multicolumn{2}{|c|}{ gradient $=45^{\circ} \mathrm{C} / \mathrm{km}$} & \\
\hline 6,000 & 2,000 & 0.33 & 0.84 & 1.8 & 2.0 \\
\hline 6,000 & 600 & 0.10 & 0.84 & 5.0 & 5.6 \\
\hline \multirow[t]{2}{*}{6,000} & 2,520 & 0.42 & 0.84 & 1.0 & 1.1 \\
\hline & \multicolumn{2}{|c|}{ Geothermal } & \multicolumn{2}{|c|}{ gradient $=30^{\circ} \mathrm{C} / \mathrm{km}$} & \\
\hline 9,000 & 3,000 & 0.33 & 0.84 & 1.8 & 4.5 \\
\hline 9,000 & 900 & 0.10 & 0.84 & 5.0 & 12.6 \\
\hline \multirow[t]{2}{*}{9,000} & 3,780 & 0.42 & 0.84 & 1.0 & 2.5 \\
\hline & \multicolumn{2}{|c|}{ Geothermal } & \multicolumn{2}{|c|}{ gradient $=60^{\circ} \mathrm{C} / \mathrm{km}$} & \\
\hline 4,500 & 1,485 & 0.33 & 0.84 & 1.8 & 1.1 \\
\hline 4,500 & 450 & 0.10 & 0.84 & 5.0 & 3.1 \\
\hline 4,500 & 1,890 & 0.42 & 0.84 & 1.0 & 0.6 \\
\hline
\end{tabular}

constant for thermal diffusion $\left(t_{\text {diff }}\right)=H^{2} \div \kappa$, and the time constant for advection $\left(t_{\text {adv }}\right)=H \div(V \sin \theta)$. The two-dimensional Peclet number is equal to the ratio of $\left(t_{\text {diff }}\right) \div\left(t_{\text {adv }}\right)$. If we assume an average dip angle of $10^{\circ}$ for $\theta$ and maintain the original boundary conditions from above, the Peclet number is equal to $\sim 1.0$. The value of $P e$ would be expected to increase substantially where the fault plane steepens, such as in the vicinity of a ramp anticline in the hanging wall. For example, recalculation using a dip angle of $30^{\circ}$ leads to a solution of $P e=2.8$. Given reasonable parameter values, the rate of heat transfer into the Tatonduk belt should have been faster than the rate of advective transfer out of the hanging wall. Numerical modeling, therefore, supports the hypothesis of a conductive thrust aureole.

It is interesting to note that values of illite crystallinity within the footwall aureole $\left(0.57\right.$ to $\left.0.46 \Delta^{\circ} 2 \theta\right)$ do not deviate much with respect to the Nation River average of $0.52 \Delta^{\circ} 2 \theta$ (Underwood and others, 1992). Thus, the temperature increase evidently was insufficient (in magnitude and (or) duration) to change $\mathrm{CI}$ beyond the levels inherited from detrital source rocks and (or) earlier stages of burial diagenesis. At a temperature of $250^{\circ} \mathrm{C}$, the expected equilibrium CI value is $\sim 0.47 \Delta^{\circ} 2 \theta$, on the basis of the data compilations of Underwood and others (1993). As documented by Barker (1989), vitrinite reflectance appears to stabilize within 10,000 $\mathrm{yr}$ in zones of high heat flow (geothermal systems). On the
Table 4. Geometric and thermal conditions required for elimination of footwall aureole beneath the Glenn Creek Fault (assumed heating time $=2$ m.y.).

[ $H$, thickness of overthrust sheet; $X$, depth below fault surface; $L$, horizontal distance from present fault trace; $T^{*}$, nondimension temperature $\left(T \div T_{b}\right.$, where $T=$ temperature at depth $=X$ and $T_{b}=$ temperature at base of hanging wall); $\tau$, nondimensional time ( $\kappa t \div H^{2}$, where $\kappa=$ thermal diffusivity and $t=$ heating time in $\mathrm{m} . \mathrm{y}$.); $D^{*}$, nondimensional depth $(X \div H)]$

\begin{tabular}{rrrrrrr}
\hline$H(\mathrm{~m})$ & $X(\mathrm{~m})$ & $L(\mathrm{~km})$ & $T_{b}\left({ }^{\circ} \mathrm{C}\right)$ & $T^{*}$ & $\tau$ & $D^{*}$ \\
\hline 5,0001 & $<0$ & 6 & 245 & 0.59 & 2.5 & -0.15 \\
4,0001 & $<0$ & 11 & 200 & 0.72 & 4 & 0.00 \\
3,000 & $<540$ & 17 & 155 & 0.94 & 7 & 0.18 \\
2,000 & $<1,140$ & 23 & 110 & 1.32 & 16 & 0.57 \\
\hline
\end{tabular}

1 Erroneous solution (in other words, entire footwall will be reset).

other hand, it is well established that illite-smectite reactions and associated changes in $C I$ values tend to lag behind increases in $R_{m}$ during rapid heating events (geothermal or igneous) because of comparatively sluggish inorganic reaction rates (Pevear and others, 1980; Duba and Williams-Jones, 1983; Smart and Clayton, 1985; Barker and others, 1986; Kisch, 1987). The Nation River CI data, therefore, provide indirect support of the thrust-aureole rapid-heating hypothesis, as opposed to a scenario in which the thermal-maturity anomaly might be attributed to passive long-term burial beneath an abnormally thick section of Jurassic and Cretaceous overburden.

It would be helpful to be able to calculate the time required for authigenic illite to equilibrate within a given temperature and fluid-composition regime and then use this time as the minimum limit for the duration of heating in the Tatonduk footwall. Unfortunately, although kinetic models have been proposed for the transformation of smectite to illite (for example, Eberl and Hower, 1976; Bethke and Altaner, 1986; Pytte and Reynolds, 1989), we know of no such quantitative assessment of kinetic parameters for illite crystallinity. The possible effects of erosion on heating duration, however, can be calculated using another version of the Peclet number (Endignoux and Wolf, 1990), in which the velocity and thickness parameters are specified in terms of erosion:

$$
P e=\left(V_{\text {erosion }}\right)\left(H_{\text {erosion }}\right) \div \kappa
$$

In this case, $P e>1$ means that the overburden is removed and heat lost by advection before appreciable conduction into the lower plate can occur. Above the Glenn Creek footwall aureole, a thermal balance could have been attained $(P e=1)$ by removing half the hanging-wall thickness $(3,000 \mathrm{~m})$ at a rate of approximately $1 \mathrm{~cm} / \mathrm{yr}$, or the entire hanging wall at a rate of $5 \mathrm{~mm} / \mathrm{yr}$. Although denudation rates of this extreme magnitude have been calculated for other orogenic belts (for example, Burbank and Beck, 1991), rapid erosion must begin immediately after $R_{m}$ values stabilize to prevent any addi- 
tional heat transfer into the footwall for illite/mica crystal growth. As discussed previously, data from apatite fission tracks demonstrate that cooling of the Kandik River terrane occurred over a much longer span of Cenomanian to Campanian time (96 to $80 \mathrm{Ma}$ ). In conclusion, even though extremely rapid denudation appears to be unwarranted, the heating event evidently did not last long enough for CI to equilibrate with the elevated temperatures generated by conduction of heat into the footwall aureole of the Glenn Creek Fault.

\section{SUMMARY AND CONCLUSIONS}

The preliminary data set of Underwood and others (1989) provided a hint that rocks to the southeast of the Glenn Creek Fault Zone (Tatonduk belt) had experienced fundamental differences in thermotectonic history with respect to the Kandik River terrane to the northwest. Our greatly expanded data set confirms most of the provisional observations and interpretations of Underwood and others (1989). Among other things, we now know that the Woodchopper Canyon, Slaven Dome, and Tacoma Bluff terranes reached paleotemperatures comparable to those of the Kandik River terrane. We suggest, therefore, that all of these suspect terranes were exposed to the same thermal overprint during middle Albian time. In addition, thermal maturity across the Glenn Creek Fault definitely is inverted with respect to stratigraphic age. Cleaved and veined Jurassic and Early Cretaceous strata of the upper part of the Glenn Shale and the Kandik Group were heated to temperatures as high as $315^{\circ} \mathrm{C}$, whereas most of the unaltered Devonian rocks of the Nation River Formation (and McCann Hill Chert) reached temperatures of about $110^{\circ} \mathrm{C}$ to $150^{\circ} \mathrm{C}$.

A major exception to the overall spatial pattern described above is associated with rocks immediately southeast of the surface trace of the Tatonduk-Kandik River terrane boundary, where paleotemperatures increased to maxima of around $250^{\circ} \mathrm{C}$. Thrusting of a warm Kandik River hanging wall over the Tatonduk belt produced a footwall aureole of reset $R_{m}$ values, and the heat transfer probably was accomplished by simple conduction. Illite crystallinity values were not reset within the aureole, and this was probably because the duration of heating was relatively brief. New data are consistent with the following choices for input parameters in an overthrust-conduction model: (1) average geothermal gradient in hanging wall $=45^{\circ} \mathrm{C} / \mathrm{km}$, (2) hanging-wall thickness above aureole $=6 \mathrm{~km}$, (3) heating duration $=2 \mathrm{~m} . \mathrm{y}$., and (4) subthrust depth to the $250^{\circ} \mathrm{C}$ isotherm $=2 \mathrm{~km}$. Spatial termination of the aureole roughly $15 \mathrm{~km}$ beyond the present fault trace was probably caused by wedging out of the hanging wall along a ramp anticline. Kandik River strata may have been transported by thrusting much farther to the southeast, but the hanging wall became too thin there to promote sufficient conductive heat transfer for ranks of organic metamor- phism to change. Modeling shows that thinning the hangingwall wedge from $6 \mathrm{~km}$ above the present fault trace to $3 \mathrm{~km}$ above the termination point of the aureole (average dip of $\sim 10^{\circ}$ ) would be sufficient to eliminate the thermal overprint at the observed termination point of the aureole.

Borehole $R_{m}$ profiles from the Doyon No. 1 well display several kinks and isothermal segments. Although the effects of contamination due to downhole cavings must be considered in any interpretation of these data, the profiles are consistent with the idea that peak heating within the Kandik River terrane was accompanied by internal thrust imbrication and local development of excess pore-fluid pressures. The ultimate source of heat remains unknown, but we do not believe that advecting fluids, by themselves, were dominant in the overall regional heat budget. Rather, the fluids responsible for vein precipitation were largely the products of dehydration reactions that were triggered by peak conductive heating (relatively low water to rock ratios). Isotope and fluid-inclusion analyses of quartz and calcite veins support the contention that the Kandik River, Slaven Dome, and Woodchopper Canyon terranes shared a common episode of fluid migration and similar fluid-rock reactions (Shelton and others, 1992, this volume). Fluids from these suspect terranes, however, were never in communication with rocks of the Tatonduk belt. In a hydrologic sense, the Kandik River and related terranes are allochthonous with respect to the rifted edge of North America.

Our conclusion that fluids provided an insignificant regional-scale heat source is supported by analytical and numerical solutions used to evaluate the role of volatiles in the thermal history of metamorphic terranes and subduction zones (for example, Peacock, 1987, 1989; Brady, 1988; Hoisch, 1991). Those studies demonstrate that advective heat transport from a single-pass event involving pervasive flow of fluids (in other words, movement along grain boundaries and closely spaced fractures) should result in relatively minor thermal effects. Multiple-pass flow is a possibility, but this scenario requires huge volumes of fluid. Local rock temperatures can increase significantly if volatiles are focused into widely spaced conduits. However, we did not uncover any data or field observations from the study area to support the idea of focused fluid flow. Such supporting evidence might include zones of intense veining, local concentrations of hydrothermal minerals, or narrow bands of abnormally high $R_{m}$ values, particularly along or adjacent to major faults. Thus, the Kandik River and related terranes probably were altered within a regional-scale regime of high conductive heat flow.

Pronounced horizontal gradients in heat flow are unusual in sedimentary basins, except along active plate boundaries affected by magmatism or hydrothermal venting. In lithified sedimentary rock, geothermal gradients of $45^{\circ}$ to $60^{\circ} \mathrm{C} / \mathrm{km}$ correspond to heat flow values of 90 to $120 \mathrm{~mW} /$ $\mathrm{m}^{2}$. Heat flow regimes of this type occur within and immediately adjacent to active volcanic arcs (Yamano and Uyeda, 1988). Heat-flow gradients within an arc-trench gap may 
change from an average of $50 \mathrm{~mW} / \mathrm{m}^{2}$ near the trench axis to $150 \mathrm{~mW} / \mathrm{m}^{2}$ in the vicinity of the volcanic front, but even these extreme changes in thermal regime occur over distances of 75 to $100 \mathrm{~km}$. There is little geologic evidence to suggest that oceanic subduction and (or) arc magmatism occurred in east-central Alaska during the Cretaceous. Nevertheless, we view this distance $(\sim 100 \mathrm{~km})$ as the minimum separation between the Kandik River terrane and the Tatonduk belt at the time of peak heating.

Another likely tectonic environment to consider as a site for peak heating of the Kandik River terrane would be a backarc basin. Patterns of heat flow in backarc basins can be quite erratic; they will be influenced by the history of backarc rifting, as well as the existence of convective mantle flow induced by the subducting slab on the opposite side of the arc (Watanabe and others, 1977; Sclater and others, 1980; Yamano and Uyeda, 1988). Heat-flow values of approximately 100 $\mathrm{mW} / \mathrm{m}^{2}$ are common within these plate-tectonic settings.

Laughland and others (1990) speculated that the abnormally high heat flow required to produce elevated paleotemperatures within the Kandik River and related terranes may have been linked to Early Cretaceous and early Late Cretaceous volcanic activity in the Yukon-Koyukuk area (Patton and Box, 1989; Box and Patton, 1989). This accreted volcanic arc probably formed in association with an east-dipping subduction zone. Sedimentary successions on the inferred backarc side of the magmatic arc (Kobuk-Koyukuk subbasin) include a volcanogenic facies of Valanginian to Albian age plus alluvial fan, deltaic, continental shelf, and turbidite facies of Albian to Cenomanian age (Nilsen, 1989). The KobukKoyukuk outcrops are located approximately $300 \mathrm{~km}$ westnorthwest of the Kandik study area, but they could represent some of the arc-proximal equivalents to the upper part of the Glenn Shale and the Kandik Group.

Additional work obviously is required to establish better biostratigraphic, petrofacies, and thermal-maturity links between the Kandik River terrane and the Kobuk-Koyukuk subbasin. One complicating factor is that the two regions are separated today by metamorphosed Proterozoic and Paleozoic continental rocks of the Ruby terrane (Coney and Jones, 1985), dismembered ophiolitic and sedimentary rocks of Mississippian to Jurassic age (named the Tozitna terrane by Churkin and others, 1982), and thick Quaternary loess deposits of the Yukon Flats. The Tozitna terrane, however, could represent fragments of the oceanic crust that formed basement within the Yukon-Koyukuk backarc basin. In addition, the hypothesis of backarc basin deposition is consistent with petrographic analyses of sandstones from the upper part of the Biederman Argillite and the Kathul Graywacke, analyses which show that the turbidite basin experienced a sudden influx of detritus eroded from a volcanic-arc provenance (Howell and others, 1992).

Regardless of the exact paleogeographic position and plate-tectonic setting of the Kandik Group at that time of peak heating, it is clear that these Jurassic and Cretaceous rocks were far enough to the west of the rifted edge of North America that the Tatonduk belt remained unaffected by the abnormally high geothermal gradients. Deposition of the Kandik Group within a backarc basin, flanked to the east by the mature rifted edge of North America, would help explain the pronounced east to west gradient in heat flow that is indicated by thermalmaturity data. As outlined by Howell and Wiley (1987), seafloor spreading to the north in the Canada Basin, right-lateral slip along the Tintina Fault, and counter-clockwise rotation of northern Alaska during Albian time probably contributed to the long-distance displacement of the Kandik River terrane following peak heating. We suggest that this rotational event was responsible for splitting the Yukon-Koyukuk backarc basin apart, crustal shortening and internal thrust imbrication, and eventual emplacement of several "suspect" terranes onto the parautochthonous formations of the Tatonduk belt.

\section{ACKNOWLEDGMENTS}

Lu Haufu, Tom Brocculeri, Pat McClung, and Bill Arendt assisted us in the field. Special thanks to Leigh Selig, who collected samples for fission track dating from Kathul Mountain. Apatite fission track dating and analysis were completed by Paul O'Sullivan and J. Murphy. Superintendent Don Chase granted permission to sample in the Yukon-Charley Rivers National Preserve. Financial support to the University of Missouri was generously supplied by ARCO Alaska, Inc. We thank Gerry Van Kooten and his ARCO colleagues for their scientific cooperation and logistical aid. Acknowledgment is also made to the Donors of the Petroleum Research Fund, administered by the American Chemical Society, for partial support of this research (Grant No. 22773-AC2 to M.B. Underwood). We thank Dwight Bradley and Charles Barker for their helpful reviews of the manuscript.

\section{REFERENCES CITED}

Allison, C.W., 1988, Paleontology of Late Proterozoic and Early Cambrian rocks of east-central Alaska: U.S. Geological Survey Professional Paper 1449, 50 p., 18 plates.

Angevine, C.L., and Turcotte, D.L., 1983, Oil generation in overthrust belts: American Association of Petroleum Geologists Bulletin, v. 67 , p. 235-241.

Antia, D.D.J., 1986, Kinetic method for modeling vitrinite reflectance: Geology, v. 14, p. 606-608.

Barker, C.E., 1982, A rapid method for concentrating sedimentary organic matter for vitrinite reflectance analysis: Journal of Sedimentary Petrology, v. 52, p. 663-664.

1983, The influence of time on metamorphism of sedimentary organic matter in selected geothermal systems, western North America: Geology, v. 11, p. 384-388.

1988, Geothermics of petroleum systems: Implications of the stabilization of kerogen thermal maturation after a geologi- 
cally brief heating duration at peak temperature, in Magoon, L.B., ed., Petroleum systems of the United States: U.S. Geological Survey Bulletin 1870, p. 26-29.

1989, Temperature and time in the thermal maturation of sedimentary organic matter, in Naeser, N.D., and McCulloh, T.H., eds., Thermal history of sedimentary basins, methods and case histories: New York, Springer-Verlag, p. 73-98.

1991, Implications for organic maturation studies of evidence for a geologically rapid increase and stabilization of vitrinite reflectance at peak temperature: Cerro Prieto geothermal system, Mexico: American Association of Petroleum Geologists Bulletin, v. 75, p. 1852-1863.

Barker, C.E., Crysdale, B.L., and Pawlewicz, M.J., 1986, The relationship between vitrinite reflectance, metamorphic grade, and temperature in the Cerro Prieto, Salton Sea, and East Mesa geothermal systems, Salton Trough, United States and Mexico, in Mumpton, F.A., ed., Studies in diagenesis: U.S. Geological Survey Bulletin 1578, p. 83-95.

Barker, C.E., and Goldstein, R.H., 1990, Fluid-inclusion technique for determining maximum temperature in calcite and its comparison to the vitrinite reflectance geothermometer: Geology, v. 18 , p. $1003-1006$.

Barker, C.E., and Pawlewicz, M.J., 1986, The correlation of vitrinite reflectance with maximum temperature in humic organic matter, in Buntebarth, G., and Stegena, L., eds., Paleogeothermics: New York, Springer-Verlag, p. 79-93.

1993, An empirical determination of the minimum number of measurements needed to estimate the mean random vitrinite reflectance of disseminated organic matter: Organic Geochemistry, v. 20, p. 643-651.

Baskin, D.K., 1979, A method for preparing phytoclasts for vitrinite reflectance analysis: Journal of Sedimentary Petrology, v. 49, p. 633-635.

Bethke, C.M., and Altaner, S.P., 1986, Layer-by-layer mechanism of smectite illitization and application to a new rate law: Clays and Clay Minerals, v. 34, p. 136-145.

Bethke, C.M., and Marshak, Stephen, 1990, Brine migrations across North America - the plate tectonics of groundwater: Annual Review of Earth and Planetary Sciences, v. 18, p. 287-315.

Blenkinsop, T.G., 1988, Definition of low-grade metamorphic zones using illite crystallinity: Journal of Metamorphic Geology, v. 6, p. 623-636.

Bostick, N.H., 1979, Microscopic measurement of the level of catagenesis of solid organic matter in sedimentary rocks to aid exploration for petroleum and to determine former burial temperatures-a review, in Scholle, P.A., and Schluger, P.R., eds., Aspects of diagenesis: Society of Economic Paleontologists and Mineralogists Special Publication 26, p. 17-43.

Bostick, N.H., Cashman, S.M., McCulloh, T.H., and Wadell, C.T., 1978, Gradients of vitrinite reflectance and present temperature in the Los Angeles and Ventura basins, California, in Oltz, D.F., ed., Symposium in geochemistry: low temperature metamorphism of kerogen and clay minerals: Society of Economic Paleontologists and Mineralogists, Pacific Section, Special Publication, p. 65-96.

Box, S.E., and Patton, W.W., Jr., 1989, Igneous history of the Koyukuk terrane, western Alaska: constraints on the origin, evolution, and ultimate collision of an accreted island arc terrane: Journal of Geophysical Research, v. 94, p. 15843-15867.

Brabb, E.E., 1969, Six new Paleozoic and Mesozoic formations in east-central Alaska: U.S. Geological Survey Bulletin 1274-I, p. $1-26$.

Brabb, E.E., and Churkin, Michael, Jr., 1967, Stratigraphic evidence for the Late Devonian age of the Nation River Formation, eastcentral Alaska: U.S. Geological Survey Professional Paper 575D, p. D4-D15.

1969, Geologic map of the Charley River Quadrangle, eastcentral Alaska: U.S. Geological Survey Miscellaneous Geological Investigations Map I-973, scale 1: 250,000.

Brabb, E.E., and Grant, R.E., 1971, Stratigraphy and paleontology of the revised type section for the Tahkandit Limestone (Permian) in east-central Alaska: U.S. Geological Survey Professional Paper 703, p. 1-23.

Brady, J.B., 1988, The role of volatiles in the thermal history of metamorphic terranes: Journal of Petrology, v. 29, p. 11871213.

Brewer, Jon, 1981, Thermal effects of thrust faulting: Earth and Planetary Science Letters, v. 56, p. 309-328.

Burbank, D.W., and Beck, R.A., 1991, Rapid, long-term rates of denudation: Geology, v. 19, p. 1169-1172.

Burnham, A.K., and Sweeney, J.J., 1989, A chemical kinetic model of vitrinite maturation and reflectance: Geochimica et Cosmochimica Acta, v. 53, p. 2649-2657.

Churkin, Michael, Jr., Foster, H.L., Chapman, R.H., and Weber, F.R., 1982, Terranes and suture zones in east-central Alaska: Journal of Geophysical Research, v. 87, p. 3718-3730.

Coney, P.J., 1989, Structural aspects of suspect terranes and accretionary tectonics in western North America: Journal of Structural Geology, v. 11, p. 107-125.

Coney, P.J., and Jones, D.L., 1985, Accretion tectonics and crustal structure in Alaska: Tectonophysics, v. 119, p. 265-283.

Davy, Ph., and Gillet, Ph., 1986, The stacking of thrust slices in collision zones and its thermal consequences: Tectonics, v. 5, p. 913-929.

Dembicki, Harry, Jr., 1984, An interlaboratory comparison of source rock data: Geochimica et Cosmochimica Acta, v. 48, p. 26412649.

Deming, David, 1992, Catastrophic release of heat and fluid flow in the continental crust: Geology, v. 20, p. 83-86.

Deming, David, Nunn, J.A., and Evans, D.G., 1990, Thermal effects of compaction-driven groundwater flow from overthrust belts: Journal of Geophysical Research, v. 95, p. 6669-6683.

Dover, J.H., 1990a, Geology of east central Alaska: U.S. Geological Survey Open-File Report 90-289, 66 p.

1990b, Problems of terrane terminology-causes and effects: Geology, v. 18, p. 487-488.

1992, Geologic map and fold-and-thrust-belt interpretation of the southeastern part of the Charley River Quadrangle, eastcentral Alaska: U.S. Geological Survey Miscellaneous Investigation Series, I-1942, scale 1:100,000, 2 sheets, 14 p.

Dover, J.H., and Miyaoka, R.T., 1988, Reinterpreted geologic map and fossil data, Charley River Quadrangle, east-central Alaska: U.S. Geological Survey Miscellaneous Field Studies Map MF2004, 2 sheets, scale 1:250,000.

Dow, W.G., 1977, Kerogen studies and geological interpretations: Journal of Geochemical Exploration, v. 7, p. 79-87.

Duba, Daria, and Williams-Jones, A.E., 1983, The application of illite crystallinity, organic matter reflectance, and isotopic techniques to mineral exploration: A case study in southwestern Gaspe, Quebec: Economic Geology, v. 78, p. 1350-1363.

Dumitru, T.A., 1989, Constraints on uplift in the Franciscan subduction complex from apatite fission track analysis: Tectonics, 
v. 8 , p. $197-220$.

Eberl, Dennis, and Hower, John, 1976, Kinetics of illite formation: Geological Society of America Bulletin, v. 87, p. 1326-1330.

Endignoux, L., and Wolf, S., 1990, Thermal and kinematic evolution of thrust basins: A 2D numerical model, in Letouzey, J., ed., Petroleum and tectonics in mobile belts: Paris, Editions Technip, p. 181-192.

Engebretson, D.C., Cox, Allan, and Gordon, R.G., 1985, Relative motions between oceanic and continental plates in the Pacific Basin: Geological Society of America Special Paper 206, p. 159.

Foster, H.L., 1976, Geologic map of the Eagle Quadrangle, Alaska: U.S. Geological Survey Miscellaneous Geological Investigations Map I-922, scale 1:250,000, 1 sheet.

Frey, Martin, 1987, Very low-grade metamorphism of clastic sedimentary rocks, in Frey, Martin, ed., Low temperature metamorphism, New York, Chapman and Hall, p. 9-58.

Furlong, K.P., and Edman, J.D., 1984, Graphic approach to determination of hydrocarbon maturation in overthrust terrains: American Association of Petroleum Geologists Bulletin, v. 68, p. $1818-1824$.

Fyfe, W.S., and Kerrich, R., 1985, Fluids and thrusting: Chemical Geology, v. 49, p. 353-362.

Ge, Shemin, and Garvin, Grant, 1992, Hydromechanical modeling of tectonically driven groundwater flow with application to the Arkoma foreland basin: Journal of Geophysical Research, v. 97, p. 9119-9144.

Gleadow, A.J.W., Duddy, I.R., and Lovering, J.F., 1983, Fission track analysis: A new tool for the evaluation of thermal histories and exploration potential: Australia Petroleum Exploration Association Journal, v. 23, p. 93-102.

Gleadow, A.J.W., Duddy, I.R., Green, P.F., and Hegarty, K.A., 1986, Fission track lengths in the apatite annealing zone and the interpretation of mixed ages: Earth and Planetary Science Letters, v. 78, p. 245-254.

Gleadow, A.J.W., Duddy, I.R., Green, P.F., and Lovering, J.F., 1986, Confined fission track lengths in apatite: A diagnostic tool for thermal history analysis: Contributions to Mineralogy and Petrology, v. 94, p. 405-415.

Green, P.F., Duddy, I.R., Gleadow, A.J.W., and Tingate, P.R., 1985, Fission track annealing in apatite: Track length measurements and the form of the Arrhenius plot: Nuclear Tracks, v. 10, p. 323-328.

Green, P.F., Duddy, I.R., Gleadow, J.W., and Lovering, J.F., 1989, Apatite fission-track analysis as a paleotemperature indicator for hydrocarbon exploration, in Naeser, N.D., and McCulloh, T.H., eds., Thermal history of sedimentary basins, methods and case histories: New York, Springer-Verlag, p. 181-196.

Gretener, P.E., and Curtis, C.D., 1982, Role of temperature and time on organic metamorphism: American Association of Petroleum Geologists Bulletin, v. 66, p. 1124-1129.

Guidotti, C.V., and Sassi, F.P., 1976, Muscovite as a petrogenetic indicator mineral in pelitic schists: Neues Jahrbuch Mineralogie Abhandlungen, v. 127, p. 97-142.

1986, Classification and correlation of metamorphic facies series by means of muscovite $b_{0}$ data from low-grade metapelites: Neues Jahrbuch Mineralogie Abhandlungen, v. 153, p. 363-380.

Hoisch, T.D., 1991, The thermal effects of pervasive and channelized fluid flow in the deep crust: Journal of Geology, v. 99, p. 6980 .
Hood, A., Gutjahr, C.C.C., and Heacock, R.L., 1975, Organic metamorphism and the generation of petroleum: American Association of Petroleum Geologists Bulletin, v. 59, p. 986-996.

Howell, D.G., Johnsson, M.J., Underwood, M.B., Lu Haufu, and Hillhouse, J.W., 1992, Tectonic evolution of the Kandik region, east central Alaska: Preliminary interpretations, in Bradley, D.C., and Ford, A.B., eds., Geologic studies in Alaska by the U.S. Geological Survey, 1990: U.S. Geological Survey Bulletin 1999, p. 127-140.

Howell, D.G., and Wiley, T.J., 1987, Crustal evolution of northern Alaska inferred from sedimentological and structural relations in the Kandik area: Tectonics, v. 6, p. 619-631.

Hunt, J.M., Lewan, M.D., and Hennet, R.J.-C., 1991, Modeling oil generation with time-temperature index graphs based on the Arrhenius equation: American Association of Petroleum Geologists Bulletin, v. 75, p. 795-807.

Issler, D.R., 1984, Calculation of organic maturation levels for offshore eastern Canada-implications for general application of Lopatins method: Canadian Journal of Earth Science, v. 21, p. 283-304

Jones, D.L., Howell, D.G., Coney, P.J., and Monger, J.W.H., 1983, Recognition, character, and analysis of tectonostratigraphic terranes in western North America, in Hasimoto, M., and Uyeda, S., eds., Accretion tectonics in the circum-Pacific regions: Terra Scientific Publishing Company, Tokyo, p. 21-35.

Jones, D.L., Silberling, N.J., Coney, P.J., and Plafker, George, 1987, Lithotectonic terrane map of Alaska (west of the 141st meridian): U.S. Geological Survey Miscellaneous Field Studies Map MF-1874-A, scale 1:2,500,000.

Jones, D.L., Silberling, N.J., and Hillhouse, John, 1977, WrangelliaA displaced terrane in northwestern North America: Canadian Journal of Earth Sciences, v. 14, p. 2565-2577.

Karabinos, Paul, 1988, Heat transfer and fault geometry in the Taconian thrust belt, western New England: Geological Society of America Special Paper 222, p. 35-45.

Karabinos, P., and Ketcham, R., 1988, Thermal structure of active thrust belts: Journal of Metamorphic Geology, v. 6, p. 559570.

Katz, B.J., Pheifer, R.N., and Schunk, D.J., 1988, Interpretation of discontinuous vitrinite reflectance profiles: American Association of Petroleum Geologists Bulletin, v. 72, p. 926-931.

Kisch, H.J., 1983, Mineralogy and petrology of burial diagenesis (burial metamorphism) and incipient metamorphism in clastic rocks, in Larsen, G., and Chilingar, G.V., eds., Diagenesis in sediments and sedimentary rocks, part 2-Developments in Sedimentology, v. 25B: Amsterdam, Elsevier, p. 289-493.

- 1987, Correlation between indicators of very low-grade metamorphism, in Frey, Martin, ed., Low temperature metamorphism: New York, Chapman and Hall, p. 227-300.

1990, Calibration of the anchizone: A critical comparison of illite 'crystallinity' scales used for definition: Journal of Metamorphic Geology, v. 8, p. 31-46.

Kisch, H.J., and Frey, Martin, 1987, Appendix-Effect of sample preparation on the measured $10 \AA$ peak width of illite (illite 'crystallinity'), in Frey, Martin, ed., Low Temperature Metamorphism: New York, Chapman and Hall, p. 301-304.

Kohn, M.J., Orange, D.L., Spear, F.S., Rumble, Douglass, III, and Harrison, T.M., 1992, Pressure, temperature, and structural evolution of west-central New Hampshire: Hot thrusts over cold basement: Journal of Petrology, v. 33, p. 521-556.

Laughland, M.M., Underwood, M.B., and Wiley, T.J., 1990, Ther- 
mal maturity, tectonostratigraphic terranes, and regional tectonic history: An example from the Kandik area, east-central Alaska, in Nuccio, V.F., and Barker, C.E., eds., Applications of thermal maturity studies to energy exploration: Society of Economic Paleontologists and Mineralogists, Rocky Mountain Section, Special Publication, p. 97-111.

Law, B.E., Nuccio, V.F., and Barker, C.E., 1989, Kinky vitrinite reflectance well profiles: Evidence of paleopore pressure in lowpermeability, gas-bearing sequences in Rocky Mountains foreland basins: American Association of Petroleum Geologists Bulletin, v. 73, p. 999-1010.

Liou, J.G., Maruyama, Shigenori, and Cho, Moonsup, 1987, Very low-grade metamorphism of volcanic and volcaniclastic rocks - mineral assemblages and mineral facies, in Frey, Martin, ed., Low temperature metamorphism: New York, Chapman and Hall, p. 59-113.

Middleton, M.F., 1982, Tectonic history from vitrinite reflectance: Geophysical Journal of the Royal Astronomical Society, v. 68, p. 121-132.

Miyaoka, R.T., 1990, Fossil locality map and fossil data for the southeastern Charley River Quadrangle, east-central Alaska: U.S. Geological Survey Miscellaneous Field Studies Map MF-2007, scale 1:100,000, p. 1-46.

Naef, U., and Stern, W.B., 1982, Some critical remarks on the analysis of phengite and paragonite components in muscovite by X-ray diffractometry: Contributions to Mineralogy and Petrology, v. 79, p. 355-360.

Naeser, N.D., Naeser, C.W., and McCulloh, T.H., 1989, The application of fission-track dating to the depositional and thermal history of rocks in sedimentary basins, in Naeser, N.D., and McCulloh, T.H., eds., Thermal history of sedimentary basinsmethods and case histories: New York, Springer-Verlag, p. 157180.

Nilsen, T.H., 1989, Stratigraphy and sedimentology of the mid-Cretaceous deposits of the Yukon-Koyukuk Basin, west central Alaska: Journal of Geophysical Research, v. 94, p. 1592515940.

Norris, D.K., 1984, Geology of the Northern Yukon and Northwestern District of Mackenzie: Geological Survey of Canada, Map 1581A, scale 1:500,000.

O’Sullivan, P.B., Green, P.F., Bergman, S.C., Decker, J., Duddy, I.R., Gleadow, A.J.W., and Turner, D.L., 1993, Multiple phases of Tertiary uplift and erosion in the Arctic National Wildlife Refuge, Alaska, revealed by apatite fission track analysis: American Association of Petroleum Geologists Bulletin, v. 77, p. 359385.

Oxburgh, E.R., and Turcotte, D.L., 1974, Thermal gradients and regional metamorphism in overthrust terrains with special reference to the eastern Alps: Schweizerische Mineralogische und Petrographische Mitteilungen, v. 54, p. 641-662.

Padan, Ady, Kisch, H.J., and Shagam, Reginald, 1982, Use of the lattice parameter $\mathrm{b}_{0}$ of dioctahedral illite/muscovite for the characterization of $\mathrm{P} / \mathrm{T}$ gradients of incipient metamorphism: Contributions to Mineralogy and Petrology, v. 79, p. 85-95.

Patton, W.W., Jr., and Box, S.E., 1989, Tectonic setting of the YukonKoyukuk basin and its borderlands, western Alaska: Journal of Geophysical Research, v. 94, p. 15807-15820.

Pawlewicz, M.J., 1987, Polishing method for dispersed vitrinite and coal slides: Society for Organic Petrology Newsletter, v. 4, p. 1.

Payne, M.W., and Allison, C.W., 1981, Paleozoic continental-mar- gin sedimentation in east-central Alaska: Geology, v. 9, p. 274 279.

Peacock, S.M., 1987, Thermal effects of metamorphic fluids in subduction zones: Geology, v. 15, p. 1057-1060.

1989, Numerical constraints on rates of metamorphism, fluid production, and fluid flux during regional metamorphism: Geological Society of America Bulletin, v. 101, p. 476-485.

Pevear, D.R., Williams, V.E., and Mustoe, G.E., 1980, Kaolinite, smectite, and K-rectorite in bentonites: Relation to coal rank at Tulameen, British Columbia: Clays and Clay Minerals, v. 28, p. 241-254.

Potter, R.W., II, 1977, Pressure corrections for fluid-inclusion homogenization temperatures based on the volumetric properties of the system NaCl-H2O: U.S. Geological Survey Journal of Research, v. 5, p. 603-607.

Price, L.C., 1983, Geologic time as a parameter in organic metamorphism and vitrinite reflectance as an absolute paleogeothermometer: Journal of Petroleum Geology, v. 6, p. 5-38.

Pytte, A.M., and Reynolds, R.C., 1989, The thermal transformation of smectite to illite, in Naeser, N.D., and McCulloh, T.H., eds., Thermal history of sedimentary basins - methods and case histories: New York, Springer-Verlag, p. 133-140.

Ritter, Ulrich, 1984, The influence of time and temperature on vitrinite reflectance: Organic Geochemistry, v. 6, p. 473-480.

Robinson, D., Warr, L.N., and Bevins, R.E., 1990, The illite 'crystallinity' technique: A critical appraisal of its precision: Journal of Metamorphic Geology, v. 8, p. 333-344.

Rubey, W.W., and Hubbert, M.K., 1959, Role of fluid pressure in mechanics of overthrust faulting: Geological Society of America Bulletin, v. 70, p. 115-206.

Sassi, F.P., and Scolari, A., 1974, The $b_{0}$ value of the potassic white micas as a barometric indicator in low-grade metamorphism of pelitic schists: Contributions to Mineralogy and Petrology, v. 45 , p. $143-152$.

Sclater, J.C., Jaupart, C., and Galson, D., 1980, The heat flow through oceanic and continental crust and the heat loss of the earth: Reviews in Geophysics and Space Physics, v. 18, p. 269-311.

Shelton, K.L., Underwood, M.B., Bergfeld, Deborah, and Howell, D.G., 1992, Isotopic variations in calcite veins from the Kandik region of east-central Alaska, in Bradley, D.C., and Dusel-Bacon, Cynthia, eds., Geologic studies in Alaska by the U.S. Geological Survey, 1991: U.S. Geological Survey Bulletin 2041, p. 213-221.

Shi, Yaolin, and Wang, C.Y., 1987, Two-dimensional modeling of the P-T-t paths of regional metamorphism in simple overthrust terrains: Geology, v. 15, p. 1048-1051.

Sibson, R.H., Moore, J.McM., and Rankin, A.H., 1975, Seismic pumping - a hydrothermal fluid transport mechanism: Journal of the Geological Society of London, v. 131, p. 653-659.

Smart, G., and Clayton, T., 1985, The progressive illitization of interstratified illite-smectite from Carboniferous sediments of northern England and its relationship to organic maturity indicators: Clay Minerals, v. 20, p. 455-466.

Stach, E., Mackowshy, M.-Th., Teichmuller, M., Taylor, G.H., and Teichmuller, R., 1982, Stach's textbook of coal petrology: Berlin, Gerbruder Borntraeger, 511 p.

Suggate, R.P., 1982, Low-rank sequences and scales of organic metamorphism: Journal of Petroleum Geology, v. 4, p. 377392.

Summer, N.S., and Verosub, K.L., 1987, Maturation anomalies in 
sediments underlying thick volcanic strata, Oregon: Evidence for a thermal event: Geology, v. 15, p. 30-33.

1992, Diagenesis and organic maturation of sedimentary rocks under volcanic strata, Oregon: American Association of Petroleum Geologists Bulletin, v. 76, p. 1190-1199.

Sweeney, J.J., and Burnham, A.K., 1990, Evaluation of a simple model of vitrinite reflectance based on chemical kinetics: American Association of Petroleum Geologists Bulletin, v. 74, p. 1559-1570.

Thompson, A.B., and England, P.C., 1984, Pressure-temperaturetime paths of regional metamorphism II. Their inference and interpretation using mineral assemblages in metamorphic rocks: Journal of Petrology, v. 25, p. 929-955.

Underwood, M.B., 1989, Temporal changes in geothermal gradient, Franciscan subduction complex, northern California: Journal of Geophysical Research, v. 94, p. 3111-3125.

Underwood, M.B., Brocculeri, Thomas, Bergfeld, Deborah, Howell, D.G., and Pawlewicz, Mark, 1992, Statistical comparison between illite crystallinity and vitrinite reflectance, Kandik region of east-central Alaska, in Bradley, D.C., and Dusel-Bacon, Cynthia, eds., Geologic studies in Alaska by the U.S. Geological Survey, 1991: U.S. Geological Survey Bulletin 2041, p. 222-237.

Underwood, M.B., Laughland, M.M., and Kang, S.M., 1993, A comparison between organic and inorganic indicators of diagenesis and metamorphism, Upper Shimanto Group, Muroto Peninsula, Shikoku, Japan, in Underwood, M.B., ed., Thermal evolution of the Tertiary Shimanto Belt, southwest Japan: An example of ridge-trench interaction: Geological Society of America Special Paper 273, p. 45-62.
Underwood, M.B., Laughland, M.M., Wiley, T.J., and Howell, D.G., 1989, Thermal maturity and organic geochemistry of the Kandik Basin region, east-central Alaska: U.S. Geological Survey OpenFile Report 89-353, 41 p.

Watanabe, T., Langseth, M.G., and Anderson, R.N., 1977, Heat flow in back-arc basins of the western Pacific, in Talwani, Manik, and Pitman, W.C., eds., Island arcs, deep-sea trenches, and back-arc basins: American Geophysical Union, Maurice Ewing Series, v. 1, p. $137-167$.

Waples, D.W., 1980, Time and temperature in petroleum explorationApplication of Lopatin's method to petroleum exploration: American Association of Petroleum Geologists Bulletin, v. 64, p. 916926.

Wintsch, R.P., Sutter, J.F., Kunk, M.J., Aleinikoff, J.N., and Dorais, M.J., 1992, Contrasting P-T-t paths: Thermochronologic evidence for a late Paleozoic final assembly of the Avalon composite terrane in the New England Appalachians: Tectonics, v. 11, p. 672689.

Wood, D.A., 1988, Relationships between thermal maturity indices calculated using Arrhenius equation and Lopatin method: Implication for petroleum exploration: American Association of Petroleum Geologists Bulletin, v. 72, p. 115-135.

Wright, N.J.R., 1980, Time, temperature, and organic maturation: The evolution of rank within a sedimentary pile: Journal of Petroleum Geology, v. 2, p. 411-425.

Yamano, Makoto, and Uyeda, Seiya, 1988, Heat flow, in Nairn, A.E.M., Stehli, F.G., and Uyeda, Seiya, eds., The ocean basins and margins, v. 7B: Plenum Publishing Corporation, p. 523-557.

Young, G.M., 1982, The late Proterozoic Tindir Group, east-central Alaska: Evolution of a continental margin: Geological Society of America Bulletin, v. 93, p. 759-783. 


\title{
Stable-Isotope and Fluid-Inclusion Studies of Hydrothermal Quartz and Calcite Veins from the Kandik Thrust Belt of East-Central Alaska-Implications for Thermotectonic History and Terrane Analysis
}

\author{
By Kevin L. Shelton ${ }^{1}$, Michael B. Underwood ${ }^{1}$, Isac B. Burstein ${ }^{1}$, \\ G. Ted Haeussler ${ }^{1}$, and David G. Howell ${ }^{2}$
}

\section{CONTENTS}

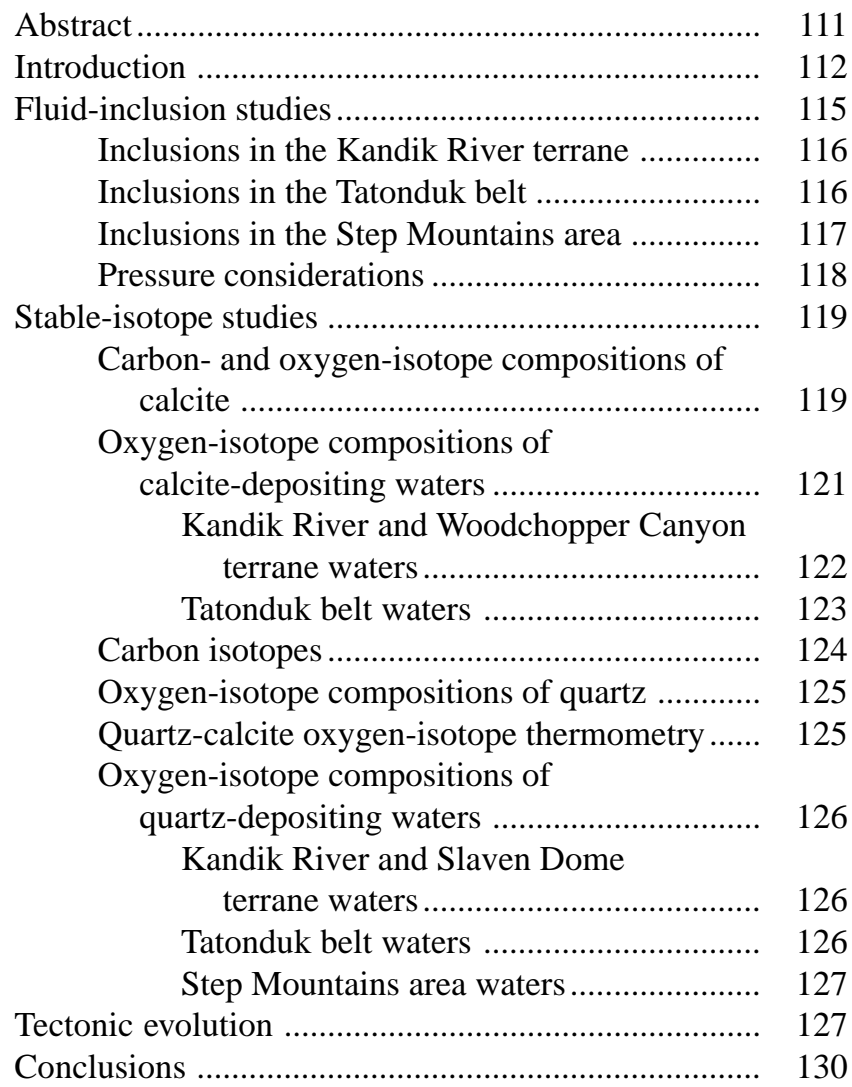

${ }^{1}$ Stable Isotope Geology and Geochemistry Group, Department of Geological Sciences, University of Missouri, Columbia, MO 65211.

${ }^{2}$ U.S. Geological Survey, 345 Middlefield Road, Mail Stop 902, Menlo Park, CA 94025

Abstract

111

Introduction .......

Inclusions in the Kandik River terrane ............ 116

Inclusions in the Tatonduk belt ......................... 116

Inclusions in the Step Mountains area .............. 117

118 19 (1)
Acknowledgments

References cited.... 130

(2)

enced a distinct fluid/thermal history with respect to the $\mathrm{Pa}$ leozoic edge of western North America.

Quartz veins hosted in Proterozoic rocks of the Tatonduk belt (Tindir Group) preserve a high-temperature event 
$\left(T_{h}=225^{\circ}\right.$ to $\left.340^{\circ} \mathrm{C}\right)$ that predates the terrane amalgamation history. Calculated $\delta^{18} \mathrm{O}_{\text {water }}$ values for fluids precipitating these veins (16.1 to 17.5 per mil) are similar to values for fluids that precipitated veins in the Kandik River terrane. However, fluid inclusions in Tatonduk belt veins are significantly less saline (approximately seawater salinity) than those in the Kandik River terrane ( 2 to 3 times seawater salinity), indicating that although high temperature veins in each domain formed from isotopically similar fluids, the fluids were not the same in other respects.

Following vein formation, methane-rich fluids were trapped along healed fractures in quartz veins in the Kandik River terrane. These fluid inclusions indicate pressures of approximately 800 to 1,500 bars at the time of methane entrapment; the corresponding depths were approximately 3 to 6 $\mathrm{km}$ or 8 to $15 \mathrm{~km}$, respectively, assuming purely lithostatic or hydrostatic pressure regimes.

Pressure estimates for methane-bearing fluid inclusions (800 to 1,500 bars) are higher than those calculated for quartz vein emplacement (500 to 800 bars), and this may indicate that (1) the Kandik River terrane was buried more deeply (through thrust imbrication) following vein emplacement and prior to methane entrapment and (or) that (2) the pressure conditions shifted from a more hydrostatic toward a more lithostatic regime as a result of fracture sealing by quartzcalcite vein deposition.

If, prior to methane entrapment, the Kandik River terrane had been deeper than during vein formation, then there must have been significant later rapid uplift and unroofing prior to the accumulation of overlying thermally immature sedimentary rocks (unit TKs). Apatite-fission-track data from the uppermost stratigraphic unit of the Kandik River terrane (Kathul Graywacke) indicate that the cooling of the Kandik River terrane through a temperature of about $100^{\circ}$ to $125^{\circ} \mathrm{C}$ occurred at $\sim 96 \mathrm{Ma}$ (Albian age). The oldest fossils in the overlying unit TKs are Late Cretaceous, and the Kathul Graywacke has been correlated with Albian strata. This indicates that hydrothermal veining at temperatures up to $300^{\circ} \mathrm{C}$, significant burial and introduction of methane, and subsequent uplift and unroofing all occurred within a narrow time window of approximately $15 \mathrm{~m} . \mathrm{y}$.

\section{INTRODUCTION}

The Kandik region of east-central Alaska (fig. 1) has been the site of multidisciplinary studies of the effects of thrust faulting on thermal structure. As outlined by Underwood and others (1992), the study area contains two major tectonostratigraphic units, herein referred to as the Kandik River terrane (dominated by Mesozoic deep-marine strata) and the Tatonduk belt (mostly Proterozoic to Permian in age) (fig. 2) (see also Churkin and others, 1982; Howell and Wiley, 1987; Dover, 1990; Dover and Miyaoka, 1988; Miyaoka, 1990; Howell and others, 1992). Pelitic rocks of the Kandik
River terrane (Glenn Shale and Biederman Argillite) typically have well-developed pressure-solution cleavage and (or) pencil structure and relatively high ranks of organic metamorphism. Conversely, the Tatonduk belt is mildly deformed and much lower in thermal maturity (Laughland and others, 1990). Basement rocks within this belt belong to the Tindir Group (Proterozoic to lower Cambrian) and the Tatonduk stratigraphy represents a rifted continental margin that experienced thermal subsidence during the Paleozoic (Payne and Allison, 1981; Howell and Wiley, 1987; Dover, 1990). The western portion of the study area contains diverse sequences of rocks that Churkin and others (1982) assigned to the Woodchopper Canyon, Slaven Dome, and Takoma Bluff terranes (fig. 1). Rock units within these smaller terranes include (1) the Nation River Formation (Devonian), (2) the Step Conglomerate (Permian), (3) sequences of Paleozoic argillite, chert, limestone, and dolomite (units Pza and Pzl of Brabb and Churkin, 1969), (4) the Woodchopper Volcanics (Devonian), and (5) argillite, dolomite, and volcanic rocks of Proterozoic(?) age (fig. 2).

Fault contacts separate the Kandik River terrane from the Woodchopper Canyon, Slaven Dome, and Takoma Bluff terranes. Churkin and others (1982) referred to this complicated region as the Eureka suture zone. Some of the Paleozoic strata within the suture zone may have formed the depositional basement of the Kandik River terrane (Howell and others, 1992). The Glenn Creek Fault Zone marks the structural boundary between the Kandik River terrane and the Tatonduk belt (fig. 1). Past field investigations have resulted in conflicting interpretations of the geometry and sense of slip on the Glenn Creek Fault (Brabb and Churkin, 1969; Howell and Wiley, 1987; Dover and Miyaoka, 1988; Laughland and others, 1990). Measurements of kinematic indicators, however, provide evidence that the fault is a southeast-verging thrust, with younger rocks of the Kandik River terrane thrust over the older Tatonduk belt rocks (Howell and others, 1992). This orogenic event evidently occurred during Albian time. Stratigraphic and structural relations between the Mesozoic siliciclastic rocks of the Kandik River terrane and Devonian to Permian strata that crop out in the Step Mountains region are uncertain (fig. 1). The Step Mountains region has been interpreted as a simple anticline (Dover, 1990), a displaced slice of the Takoma Bluff terrane (Howell and others, 1992), and a window through a folded Glenn Creek Fault that exposes footwall strata of the Tatonduk belt (Laughland and others, 1990).

Vitrinite-reflectance and illite-crystallinity data (Underwood and others, 1992, this volume) uphold interpretations derived from an earlier reconnaissance-level investigation of thermal maturity (Laughland and others, 1990). These data are important because they provide independent confirmation of the widespread occurrence of low-grade metamorphic rocks in the hanging wall of the Glenn Creek Fault. The footwall sequences, in contrast, are much lower in thermal maturity (fig. 3); for example, the average value of mean 
random vitrinite reflectance (percent $R_{m}$ ) is 3.8 percent for the Kandik River terrane, whereas a comparable average percent $R_{m}$ value for the Tatonduk belt is only 1.2 percent (Underwood and others, 1992). Using the correlation between percent $R_{m}$ and paleotemperature established by Barker (1988), these data correspond to average temperature estimates (fig.
3 ) of about $285^{\circ} \mathrm{C}$ (Kandik River terrane) and $165^{\circ} \mathrm{C}$ (Tatonduk belt). Likewise, illite-crystallinity-index values for the Kandik River terrane typically fall within the boundaries of the zone of anchimetamorphism (transition into lowermost greenschist facies). In contrast, the Tatonduk belt displays extreme scatter and inconsistency in illite crystallinity owing

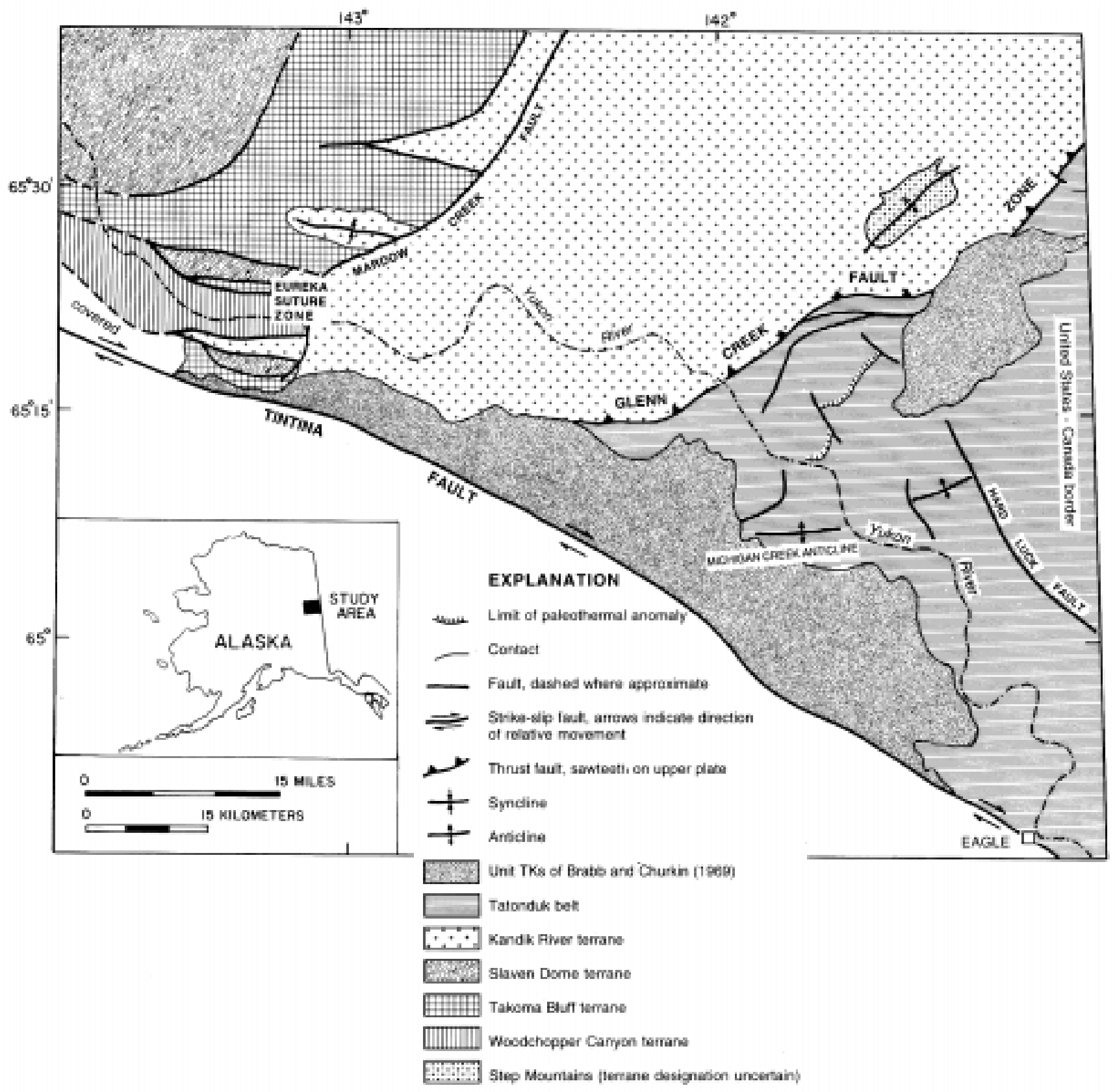

Figure 1. Geologic index map of east-central Alaska showing Kandik River terrane and Tatonduk belt. Tectonostratigraphic designation for rocks at Step Mountains is disputed. Hachured line southeast of Glenn Creek Fault represents detected limit of a footwall thermal aureole. Also shown are unit TKs of Brabb and Churkin (1969) and Woodchopper Canyon, Slaven Dome, and Takoma Bluff terranes of
Eureka suture zone (Churkin and others, 1982). Rocks southwest of Tintina Fault Zone are assigned to Yukon-Tanana composite terrane (Coney and Jones, 1985). Modified from Brabb and Churkin (1969) and Foster (1976). For relevant fossil control and alternative interpretations of structural geology, see Dover and Miyaoka (1988), Miyaoka (1990), and Dover (1992). 
to the effects of mixing among authigenic clay minerals and detrital populations of illite and muscovite inherited from a variety of source rocks (Underwood and others, 1992, this volume).

A complete understanding of the regional thermal history and its relation to the history of rock deformation cannot be achieved without considering the role of fluid migration. Perhaps the best evidence for the fluid-migration history comes from mineral phases that were precipitated as vein fillings. Veins containing calcite, quartz, and quartz-calcite intergrowths are ubiquitous in the cleaved and complexly folded sequences of the Kandik River terrane. Although we made a concerted effort to sample (fig. 4) and measure both common and unusual vein orientations, most of the veins are aligned at high angles to bedding and (or) cleavage, locally filling conjugate sets of fractures (Shelton and others, 1992). On the other hand, quartz-calcite veins in the Tatonduk belt occur sporadically, and there is little sense of systematic orientation.

Shelton and others (1992) presented initial results and tentative interpretations of isotopic analyses of calcite veins. Those data are suggestive of independent fluid systems for the Tatonduk belt with respect to the Kandik River and Woodchopper Canyon terranes. Based on Shelton and others' (1992) study, it appears as though rock units to the west of the Glenn Creek Fault Zone (fig. 1) are allochthonous with respect to the Paleozoic edge of western North America. In earlier, preliminary studies, Shelton and others (1992) referred to the

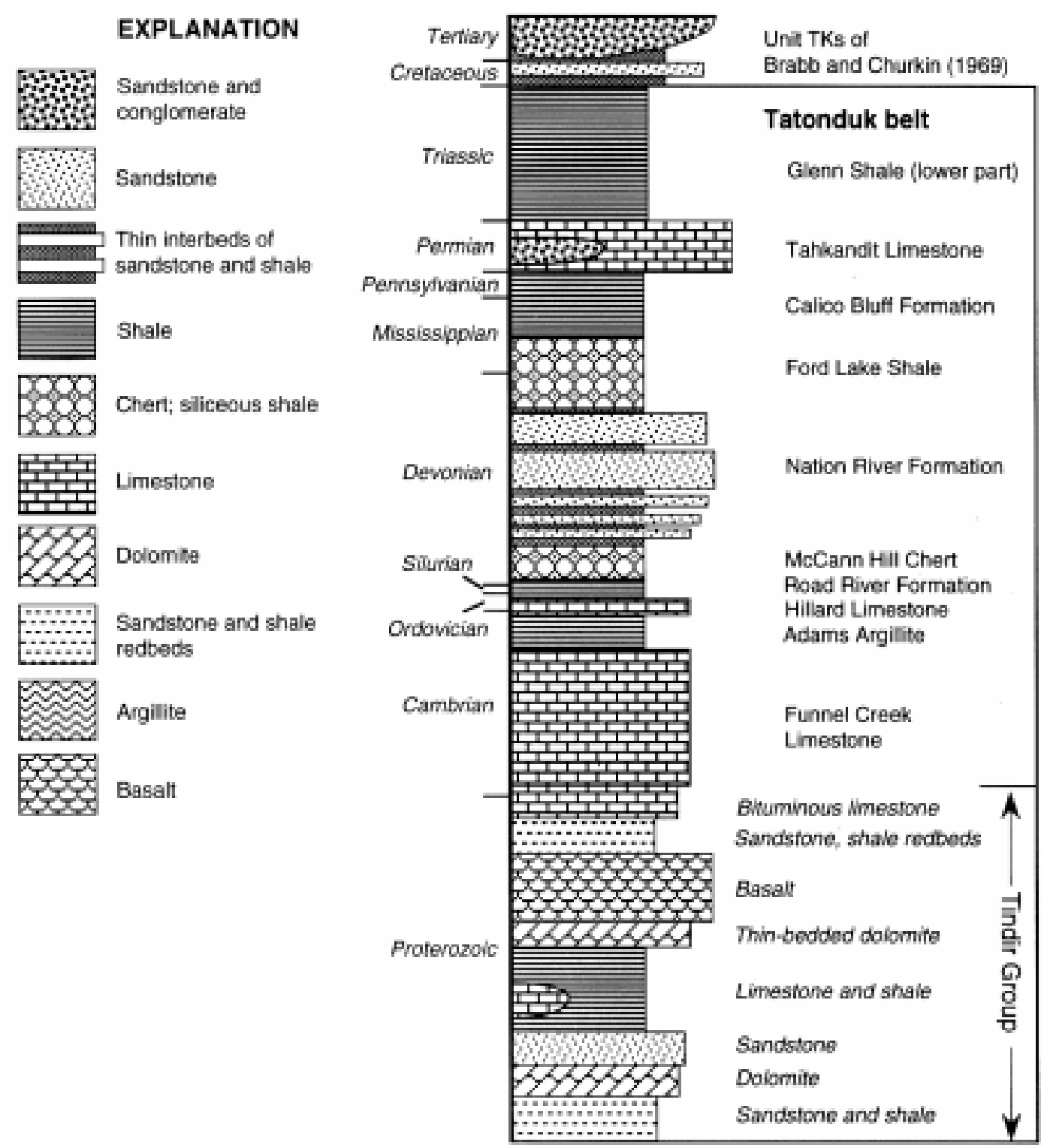

Figure 2. Schematic stratigraphic sections for Tatonduk belt and Kandik River, Takoma Bluff, Woodchopper Canyon, and Slaven Dome terranes. Modified from Howell and others (1992). 
tectonostratigraphic domains as belts to avoid the connotation of exotic origins or long-distance dislocation. However, given the new data contained herein, there is a clear divergence in the thermotectonic history of these domains such that use of the term Kandik River "terrane" now seems justified.

The purpose of this paper is to document the isotopic signatures of quartz-calcite veins and microthermometric data for fluid inclusions in the various terranes of the Kandik thrust belt of east-central Alaska. From these data, we estimate temperatures of vein precipitation, fluid compositions and salinities, isotopic character of parent fluids (from which the veins

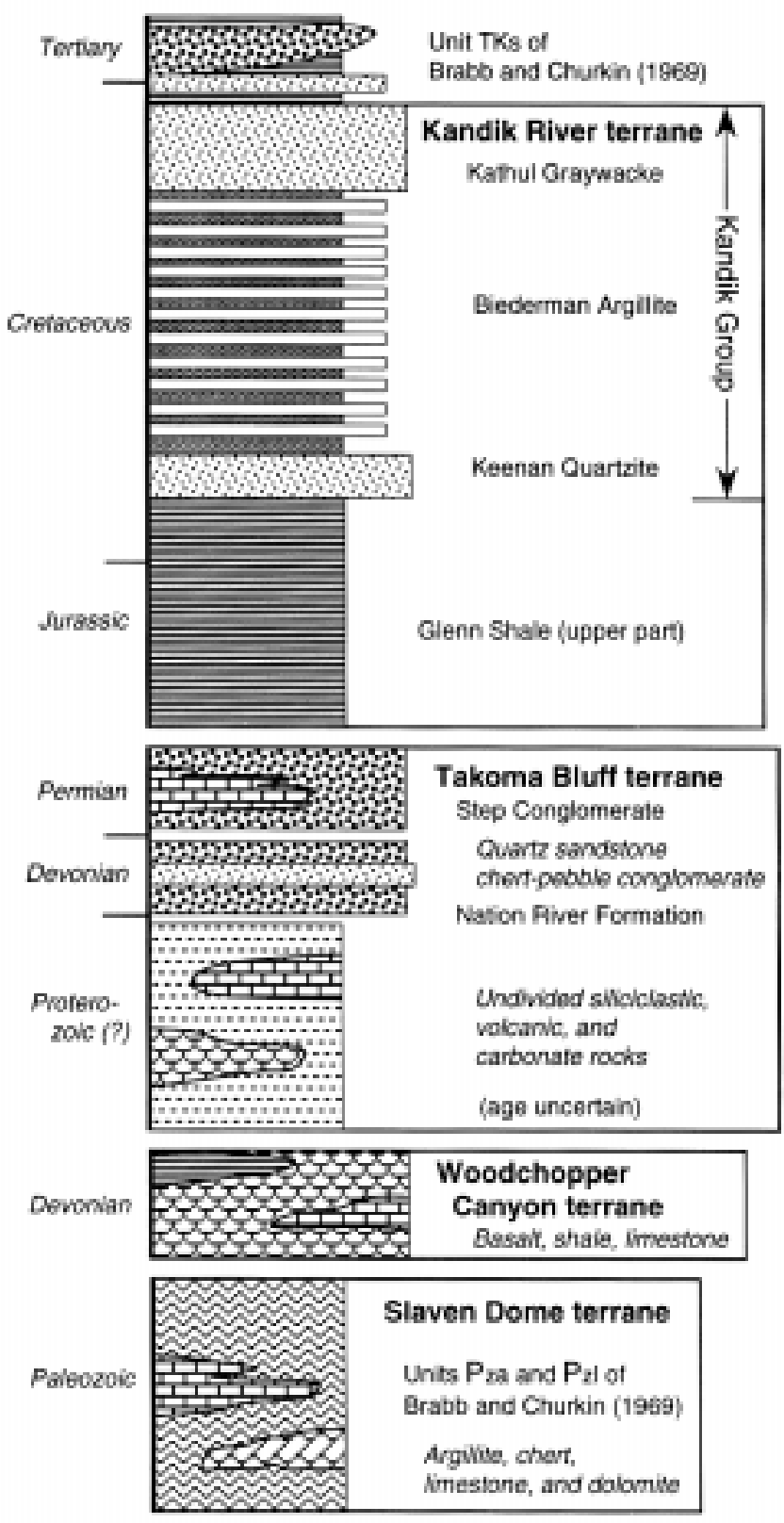

Figure 2. Continued. precipitated), degree of fluid-rock interaction, and ultimately, the sources of fluids that moved through the various terranes.

\section{FLUID-INCLUSION STUDIES}

We examined fluid inclusions in 16 samples of quartz (11 from the Kandik River terrane, 4 from the Tatonduk belt, and 1 from the Step Mountains anticline area) to document the ranges of fluid compositions and temperatures responsible for precipitating veins. Temperatures of homogenization $\left(T_{h}\right)$ and last ice melting $\left(T_{m}\right)$ have standard errors of \pm 1.0 and $\pm 0.2^{\circ} \mathrm{C}$, respectively (table 1 ; fig. 5). Salinity data for simple, water-rich fluid inclusions are based on freezing-point depression in the system $\mathrm{H}_{2} \mathrm{O}-\mathrm{NaCl}$ (Potter and others, 1978). Salinities of $\mathrm{CO}_{2}$-bearing fluid inclusions are based on clathrate melting temperatures (Diamond, 1992).

Vein materials from the various terranes studied are far from ideal for fluid-inclusion studies, especially those from the Kandik River terrane. Calcite is generally sheared and deformed and displays fibrous habits. Fluid inclusions in these calcites are ubiquitously stretched, frequently opened, and yield unreliable, nonreproducible $T_{h}$ values. Quartz veins in the Kandik River terrane contain dominantly secondary fluid inclusions trapped along healed fractures. Unequivocal primary fluid inclusions (see Roedder, 1984, for criteria) are rare, but they yield reproducible, narrow ranges of $T_{h}$ values that are interpreted to reflect real temperatures and that are not artifacts of post-entrapment changes in inclusion volume or shape. These primary inclusions are typically small $(<5$ $\mu \mathrm{m})$, and it is difficult to observe clearly the last ice-melting temperature $\left(T_{m}\right)$ for salinity determination. Consequently, we were able to measure significantly more $T_{h}$ values (273 measurements) than $T_{m}$ values (75 measurements).

The samples examined contain two types of fluid inclusions. Predominant two-phase water-rich inclusions occur as primary, pseudosecondary, and secondary inclusions (using the criteria of Roedder, 1984) in all samples. They contain a liquid and a small vapor bubble making up 5 to 15 percent of the total volume of each inclusion at $25^{\circ} \mathrm{C}$. These inclusions contain no daughter minerals and readily homogenize to the liquid phase upon heating. Traces of gas hydrates (indicative of the presence of $\mathrm{CO}_{2}$ ) were observed in only one sample (locality MU90-K8d in the Step Mountains anticline area, fig. 4) during freezing (Diamond, 1992).

Rarer one-phase fluid inclusions occur as pseudosecondary and secondary inclusions (together with two-phase water-rich inclusions) along healed fractures in three samples from the Kandik River terrane (localities MJ90K18, MJ90-K80, UM90-K25, one located along the Glenn Creek Fault and the other two upsection in the core of the Kathul Mountain synclinorium, fig. 4). These one-phase inclusions generate a second phase upon cooling below $-135^{\circ} \mathrm{C}$, and their phase behavior on heating indicates that they are methane-rich fluid inclusions. 


\section{INCLUSIONS IN THE KANDIK RIVER TERRANE}

Primary two-phase fluid inclusions in quartz veins from the Kandik River terrane have $T_{h}$ values which range from $234^{\circ}$ to $310^{\circ} \mathrm{C}$. Their $T_{m}$ values range from $-3.0^{\circ}$ to $-4.5^{\circ} \mathrm{C}$, corresponding to salinities of 4.9 to 7.1 equivalent weight percent $\mathrm{NaCl}$ (fig. 5).

Pseudosecondary and secondary one-phase fluid inclusions generate a second phase on cooling below $-135^{\circ} \mathrm{C}$ and exhibit phase behavior indicative of methane-rich fluids. They have $T_{h}$ values (to the liquid) of $-94^{\circ}$ to $-82^{\circ} \mathrm{C}$. Calculated den- sities for these inclusions (assuming pure methane) range from 0.198 to $0.280 \mathrm{~g} / \mathrm{cm}^{3}$ (using the data and techniques of Swanenberg, 1979; Jacobs and Kerrick, 1981). Coexisting twophase water-rich fluid inclusions have $T_{h}$ values of $290^{\circ}$ to $297^{\circ} \mathrm{C}$ and $T_{m}$ values of $-3.5^{\circ}$ to $-4.5^{\circ} \mathrm{C}$.

\section{INCLUSIONS IN THE TATONDUK BELT}

Primary two-phase fluid inclusions in quartz veins hosted in Paleozoic rocks from the Tatonduk belt have $T_{h}$ values that

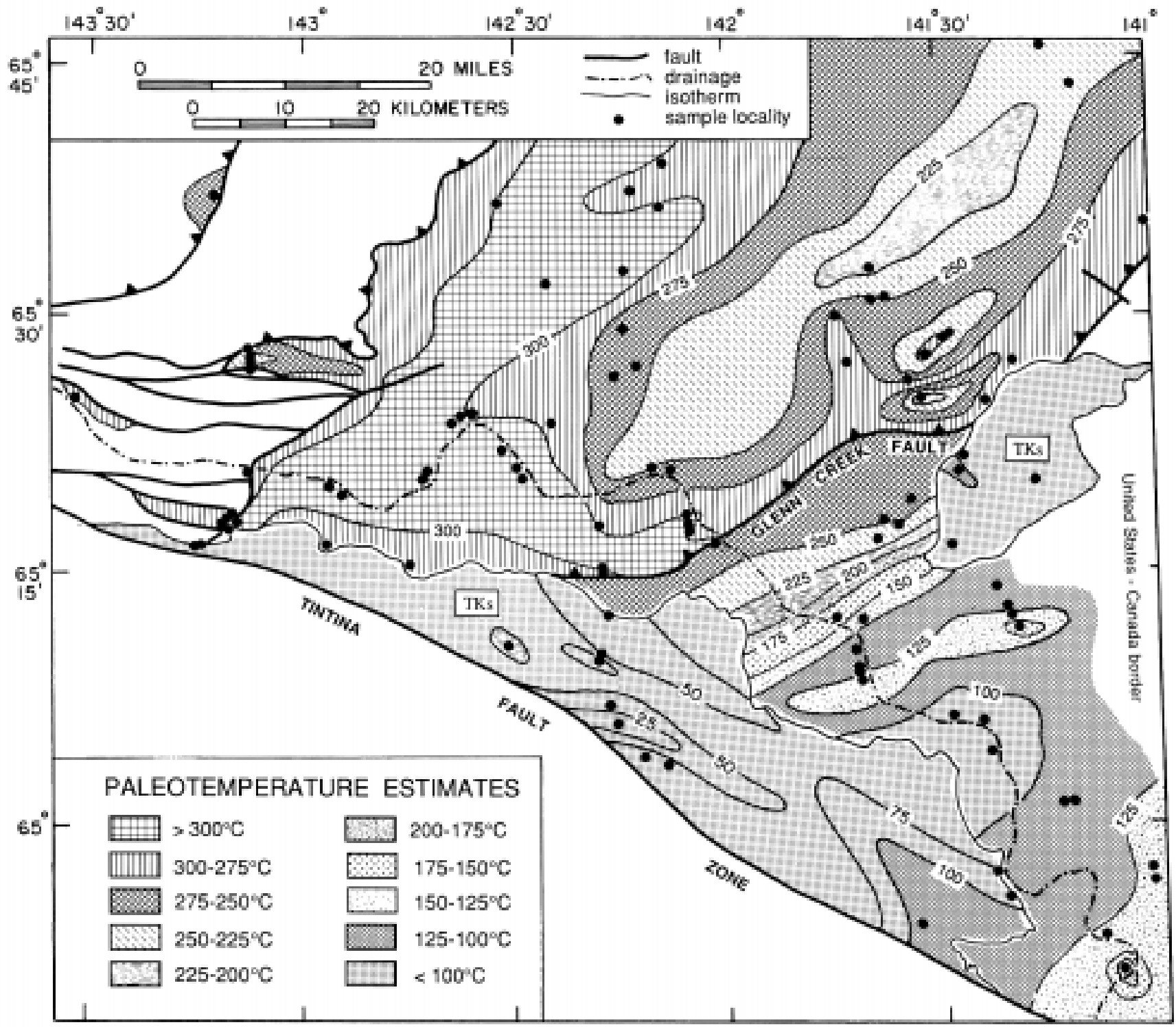

Figure 3. Contour map of paleotemperature estimates for Kandik study area. Conversions from mean random vitrinite reflectance to degrees Celsius follow regression equation of Barker (1988). Regions with insufficient data to constrain orientation of contour lines are shown without patterns. TKs, geologic unit TKs of Brabb and Churkin (1969). Patterns are broken along contacts of unit
TKs to emphasize contrast in paleothermal structure across that unconformity. Rocks southwest of Tintina Fault Zone are assigned to Yukon-Tanana composite terrane (Coney and Jones, 1985). See figure 1 for identification and distribution of major tectonostratigraphic units within Kandik study area. From Underwood and others (this volume). 
range from $121^{\circ}$ to $141^{\circ} \mathrm{C}$. Their $T_{m}$ values range from $-1.2^{\circ}$ to $-2.1^{\circ} \mathrm{C}$, corresponding to salinities of 2.0 to 3.4 equivalent weight percent $\mathrm{NaCl}$ (fig. 5).

Primary two-phase fluid inclusions in two samples from quartz veins hosted in Tindir Group rocks from the Tatonduk belt have $T_{h}$ values that range from $225^{\circ}$ to $340^{\circ} \mathrm{C}$. The $T_{h}$ data from individual samples have distinct ranges $\left(225^{\circ}\right.$ to $242^{\circ} \mathrm{C}$ and $316^{\circ}$ to $340^{\circ} \mathrm{C}$ ) which may indicate distinct thermal events. Their $T_{m}$ values, however, are similar and range from $-1.5^{\circ}$ to $-2.8^{\circ} \mathrm{C}$, corresponding to salinities of 2.5 to 4.5 equivalent weight percent $\mathrm{NaCl}$ (fig. 5). The restriction of these higher $T_{h}$ values to Proterozoic basalts and diamictites indicates that these rocks likely preserve an earlier higher temperature history that occurred prior to rifting and subsidence of the Tatonduk continental margin.

\section{INCLUSIONS IN THE STEP MOUNTAINS AREA}

The only quartz vein samples in the Kandik region that contain discernible $\mathrm{CO}_{2}$ in their fluid inclusions (noted by clathrate formation during freezing experiments) are from the Step Mountains anticline (locality UM90K8d, fig. 4), where terrane designation is in dispute. This area could represent (1) a window into the Tatonduk belt (below the Glenn Creek Fault), (2) a thrust sliver of the Tacoma Bluff terrane (from the west), or (3) a simple anticline (fig. 1).

Primary and pseudosecondary fluid inclusions in the Step Mountains sample have $T_{h}$ values of $178^{\circ}$ to $220^{\circ} \mathrm{C}$ $\left(\right.$ mean $\left.=212^{\circ} \mathrm{C}\right)$, values which are in general agreement with vitrinite-reflectance estimates of temperature for this area ( $225^{\circ}$ to $250^{\circ} \mathrm{C}$, fig. 3 ; Underwood and others, 1992 , this vol-

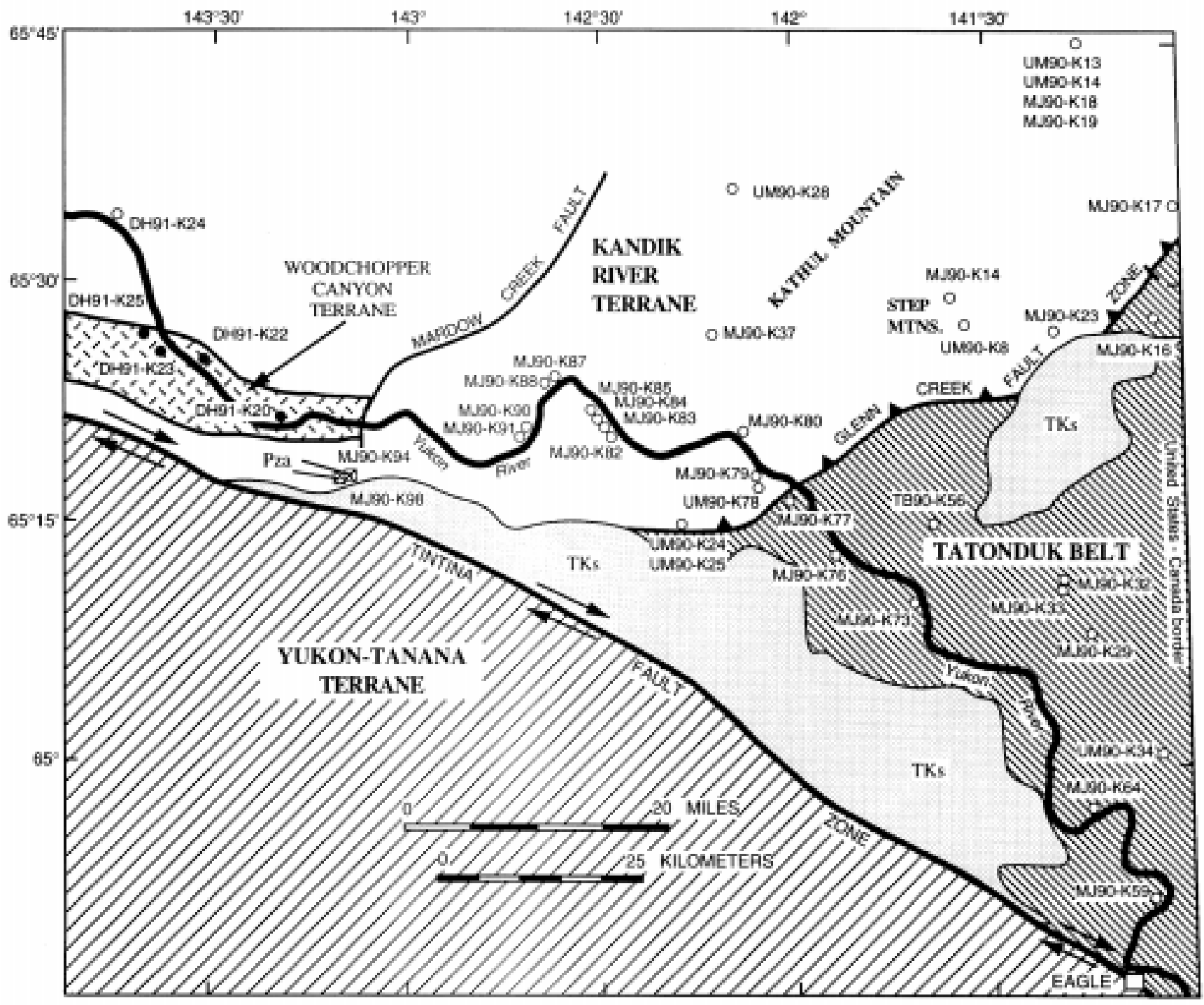

Figure 4. Sample localities for quartz-calcite veins in Tatonduk belt and Kandik River and Woodchopper Canyon terranes, east-central Alaska. TKs and Pza, geologic units of Brabb and Churkin (1969). Paired arrows along faults show relative motion; barbs along faults show downthrown side. 
Table 1. Microthermometric data for primary and pseudosecondary fluid inclusions in quartz from Kandik region, eastcentral Alaska.

$\left[T_{h}\right.$, homogenization temperature; $T_{m}$, last ice-melt temperature; equiv. wt pct , equivalent weight percent]

\begin{tabular}{|c|c|c|c|c|c|c|}
\hline Sample No. & Number of Inclusions & Inclusion type & $T_{h}\left({ }^{C}\right.$ ) & $T_{m}$ (_C) & Equiv. wt pet $\mathrm{NaCl}$ & Comments \\
\hline \multicolumn{7}{|c|}{ Kandik River terrane } \\
\hline \multirow[t]{2}{*}{ MJ90-K18g } & 3 & water-rich & 296 to 299 & -4.0 to -4.2 & 6.4 to 6.7 & small inclusions \\
\hline & 19 & methane & -82 to -83 & & & \\
\hline MJ90-K23c & 24 & water-rich & 234 to 247 & -3.0 to -3.5 & 4.9 to 5.6 & \\
\hline \multirow[t]{2}{*}{ MJ90-K80a } & 10 & water-rich & 290 to 297 & -3.0 to -4.5 & 4.9 to 7.1 & \\
\hline & 31 & methane & -87 to -94 & & & \\
\hline MJ90-K91d & 17 & water-rich & 295 to 310 & -3.9 to -4.2 & 6.3 to 6.7 & small inclusions \\
\hline \multirow[t]{2}{*}{ UM90-K25f } & 55 & methane & -86 to -88 & & & \\
\hline & \multicolumn{6}{|c|}{ Tatonduk belt } \\
\hline TB90-K56d & 22 & water-rich & 126 to 141 & -1.4 to -2.1 & 2.3 to 3.4 & Paleozoic \\
\hline TB90-K56d & 7 & water-rich & 121 to 131 & -1.2 to -1.4 & 2.0 to 2.3 & Paleozoic \\
\hline MJ90-K76d & 22 & water-rich & 316 to 340 & -1.5 to -2.8 & 2.5 to 4.5 & Proterozoic \\
\hline MJ90-K77b & 23 & water-rich & 225 to 242 & -2.1 to -2.5 & 3.4 to 4.0 & Proterozoic \\
\hline
\end{tabular}

Step Mountains area

\begin{tabular}{lllllll}
\hline UM90-K8d & 11 & water-rich & 178 to 220 & clathrate & 14.1 to 14.4 & $\mathrm{CO}_{2}$-bearing
\end{tabular}

ume). These inclusions have first-melting temperatures of approximately $-56^{\circ} \mathrm{C}$ and clathrate-melting temperatures of $1.2^{\circ}$ to $1.5^{\circ} \mathrm{C}$. Assuming that the fluid compositions can be modeled by the system $\mathrm{CO}_{2}-\mathrm{H}_{2} \mathrm{O}-\mathrm{NaCl}$, the clathrate melting temperatures correspond to salinities of 14.1 to 14.4 equivalent weight percent $\mathrm{NaCl}$ (using the data and methods of Diamond, 1992). This salinity range is much higher than in any other fluid observed in the Kandik region. Thus, the fluid inclusions in the Step Mountains area are unlike those in any other rocks in the Kandik region and do not allow us to make a definitive terrane designation for these host rocks.

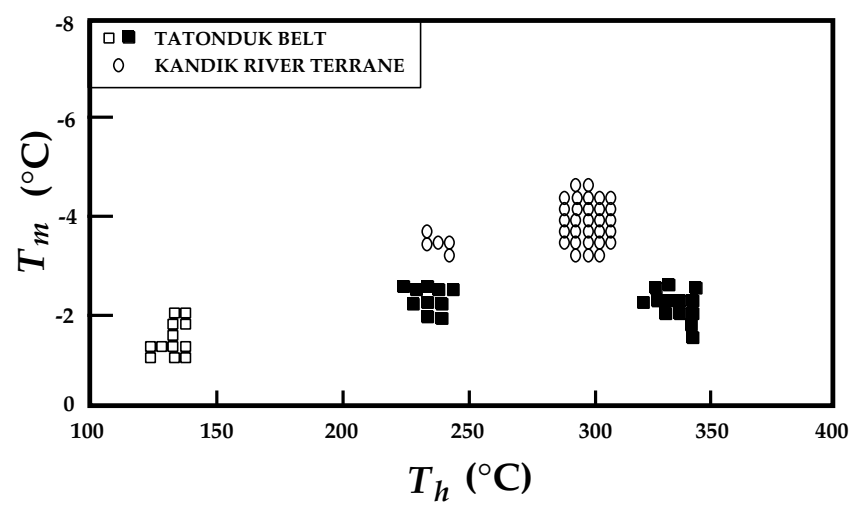

Figure 5. Distributions of last ice-melt $\left(T_{m}\right)$ and homogenization temperatures $\left(T_{h}\right)$ for primary two-phase water-rich fluid inclusions in quartz veins from Kandik River terrane and Tatonduk belt (open squares, veins hosted in Paleozoic rocks; black squares, veins hosted in Tindir Group rocks), east-central Alaska.

\section{PRESSURE CONSIDERATIONS}

$T_{h}$ values for fluid inclusions in quartz veins represent minimum estimates of the temperature of vein emplacement. Because of the effect of pressure on volumetric properties of the inclusion fluids, the actual temperature of fluid entrapment is higher (the so-called "pressure correction" to $T_{h}$ values). Vein formation in the Kandik River terrane likely occurred concomitant with organic-matter maturation, as indicated by the apparent synchroneity of quartz-calcite veining with cleavage development. The similarity of $T_{h}$ values (which represent minimum temperature estimates) to temperatures estimated from vitrinite reflectance (which reflect maximum temperature estimates) (fig. 3; Underwood and others, 1992, this volume) indicates that the pressure correction to the $T_{h}$ values is not great and that the pressures at the time of vein formation were likely $<1$ kbar. In some specimens, fluid inclusion $T_{h}$ values and temperatures estimated from oxygen-isotope fractionations between quartz and calcite actually exceed temperatures estimated from vitrinite reflectance. This discrepancy indicates that the heat flux associated solely with fluid migration probably was not great enough to reset vitrinite-reflectance values. That is, quartz veining was the result of metamorphism, not the cause, and there was limited conduction of heat away from vein margins into wall rocks.

Temperatures estimated from oxygen-isotope fractionations between quartz and calcite in veins from the Kandik River terrane (see section "Quartz-Calcite Oxygen-Isotope Thermometry") are typically $40^{\circ}$ to $70^{\circ} \mathrm{C}$ higher than $T_{h}$ values for fluid inclusions in quartz from the same veins. If these temperature differences represent the pressure correction to 
the $T_{h}$ values, they would correspond to fluid pressures of approximately 500 to 800 bars at the time of vein emplacement (Potter, 1977). Assuming purely lithostatic or hydrostatic pressure regimes, these fluid pressures correspond to depths of approximately 2 to $3 \mathrm{~km}$ or 5 to $8 \mathrm{~km}$, respectively. Using either estimate of depth, it is evident that there were unusually high thermal gradients at shallow depths within the Kandik River terrane at the time of vein formation.

Following quartz vein formation, pseudosecondary and secondary methane-rich fluid inclusions were trapped along healed fractures in quartz veins in the Kandik River terrane. These methane-rich fluid inclusions have densities (assuming pure methane) of 0.198 to $0.280 \mathrm{~g} / \mathrm{cm}^{3}$ and coexist in the same healed fractures with contemporaneous water-rich inclusions with $T_{h}$ values of $290^{\circ}$ to $297^{\circ} \mathrm{C}$. Calculations utilizing the methane densities and a temperature of $300^{\circ} \mathrm{C}$ (using the computer program MacFLINCOR of P.E. Brown, University of Wisconsin) indicate fluid pressures between approximately 800 and 1,500 bars at the time of methane entrapment. These fluid pressures correspond to depths of approximately 3 to $6 \mathrm{~km}$ and 8 to $15 \mathrm{~km}$, again assuming purely lithostatic or hydrostatic pressure regimes, respectively.

Pressure estimates for methane-bearing fluid inclusions (800 to 1,500 bars) are higher than those calculated for quartz vein emplacement (500 to 800 bars). One explanation is that the Kandik River terrane was buried more deeply after vein emplacement and prior to methane entrapment; this must have been accomplished tectonically through thrust imbrication, as there is no evidence in the stratigraphic record to account for significant Late Cretaceous burial prior to the development of the base of unit TKs. Alternatively, the fluid-pressure conditions may have shifted from a more open hydrostatic regime toward an overpressured lithostatic condition as a result of fracture sealing by quartz-calcite vein deposition. The two cases are not mutually exclusive.

If the Kandik River terrane had been buried more deeply following vein emplacement (and prior to methane entrapment), there must have been significant later unroofing and rapid uplift prior to deposition of the unconformable cover sequences represented by the thermally immature unit TKs (fig. 2). Fission-track data for apatite from the Kathul Graywacke, uppermost stratigraphic unit in the Kandik River terrane (fig. 2), constrain the cooling of some rocks in the Kandik River terrane through a temperature of about $125^{\circ} \mathrm{C}$ and indicate an Albian age (pooled age of approximately 96 Ma; Underwood and others, this volume). The oldest fossils in the overlying unit TKs are Late Cretaceous, so the basal deposits of unit TKs seem to match the timing of uplift in the Kandik River terrane. The unfossiliferous Kathul Graywacke is probably early Albian in age, on the basis of stratigraphic correlations outlined by Howell and Wiley (1987). This indicates that hydrothermal veining at temperatures up to $300^{\circ} \mathrm{C}$, significant burial and introduction of methane, and subsequent uplift and unroofing all occurred during the Albian within a time window of 15 m.y. or less.

\section{STABLE-ISOTOPE STUDIES}

Previous studies have shown the utility of stable isotopes in elucidating the origin and history of hydrothermal fluids and fluid-rock interactions in many different types of tectonically disturbed terranes (Magaritz and Taylor, 1976; Dietrich and others, 1983; Wickham and Taylor, 1987; Rye and Bradbury, 1988; Burkhard and Kerrich, 1988; Bebout and Barton, 1989; Nesbitt and Muehlenbachs, 1989; Shelton and others, 1992). In this study we measured the oxygen- and carbon-isotope compositions of vein-filling quartz and calcite and associated wall rocks. We used techniques of mineral extraction and analysis that followed those of McCrea (1950) and Clayton and Mayeda (1963) (utilizing chlorine trifluoride), and the data are reported in conventional $\delta$ notation as per mil deviations relative to the Pee Dee Belemnite (PDB) standard for carbon and Vienna standard mean ocean water (SMOW) for oxygen. The standard error for each analysis is approximately \pm 0.1 per mil, using the University of Missouri's automated Finnigan MAT Delta E mass spectrometer (tables 2 and 3).

We extracted specimens of calcite and quartz from veins plus representative whole-rock samples from a wide variety of lithologies and stratigraphic positions (table 1; figs. 2, 4, and 6). Most of the Kandik River specimens (34 calcite, 33 quartz, and 2 whole rock samples) are from sandstone beds in the Biederman Argillite (Cretaceous). In addition, we analyzed samples from the Glenn Shale (7 calcite, 9 quartz, and 2 whole rock samples), and the Keenan Quartzite (4 quartz samples). Within the Woodchopper Canyon terrane, we selected one calcite sample from a shale interval and four calcite veins cutting through the Devonian basaltic rocks.

We collected a total of 23 samples from the following units within the Tatonduk belt: (1) shale, diamictite, and basalt of the Tindir Group (Proterozoic to earliest Cambrian, 8 calcite, 4 quartz, and 1 whole rock sample), (2) Adams Argillite (Cambrian, 1 calcite and 3 quartz samples), (3) argillite of the Road River Formation (Ordovician to Devonian, 1 calcite sample), (4) turbidite sequences of the Nation River Formation (Devonian, 2 calcite and 1 quartz sample), (5) limestone and shale interbeds of the Calico Bluff Formation (Mississippian and Pennsylvanian, 1 calcite sample), and (6) the Tahkandit Limestone (Permian, 1 calcite sample). We collected two quartz samples from unit Pza of the Slaven Dome terrane (Brabb and Churkin, 1969) and two quartz samples from the Step Mountains area. All lithostratigraphic assignments (tables 1 through 3 ) are according to the maps of Brabb and Churkin (1969) and Foster (1976).

\section{CARBON- AND OXYGEN-ISOTOPE COMPOSITIONS OF CALCITE}

Shelton and others (1992) presented initial results and tentative interpretations of 38 isotopic analyses of calcite veins 
Table 2. Stable isotopic data for calcite in veins in Kandik region of east-central Alaska. [PDB, Pee Dee Belemnite standard; SMOW, Standard Mean Ocean Water standard; 1ms, limestone; ss, sandstone]

\begin{tabular}{|c|c|c|c|c|c|}
\hline Sample No. & Geologic Unit & Lithology & $\begin{array}{l}\mathrm{d}^{13} \mathrm{C} \% \text { o } \\
\text { (PDB) }\end{array}$ & $\begin{array}{l}\mathrm{d}^{18} \mathrm{O} \% \circ \\
\text { (SMOW) }\end{array}$ & Comments \\
\hline \multicolumn{6}{|c|}{ Tatonduk belt } \\
\hline MJ90-K33c & Adams & argillite & 2.9 & 6.2 & \\
\hline MJ90-K64c & Calico Bluff & $1 \mathrm{~ms} /$ shale & -0.2 & 20.2 & \\
\hline MJ90-K59f & Nation River & ss/shale & -3.2 & 18.1 & \\
\hline MJ90-K59g & Nation River & ss/shale & -2.6 & 18.6 & \\
\hline MJ90-K32c & Road River & shale & -1.8 & 6.5 & \\
\hline MJ90-K73b & Tahkandit & limestone & 1.8 & 16.2 & \\
\hline MJ90-K29b & Tindir & shale & 0.6 & 18.9 & \\
\hline MJ90-K76c & Tindir & diamictite & -2.7 & 26.4 & \\
\hline MJ90-K76d & Tindir & diamictite & -1.7 & 26.2 & \\
\hline MJ90-K77a & Tindir & basalt & -0.7 & 22.0 & intimate with quartz \\
\hline MJ90-K77a & Tindir & basalt & 0.8 & 26.2 & \\
\hline MJ90-K77c & Tindir & basalt & -2.1 & 15.4 & \\
\hline MJ90-K77d & Tindir & basalt & -2.3 & 12.9 & \\
\hline UM90-K34b & Tindir & 1ms/shale & 7.6 & 21.3 & \\
\hline
\end{tabular}

\begin{tabular}{|c|c|c|c|c|c|}
\hline \multicolumn{3}{|c|}{ Kandik River and } & \multicolumn{2}{|c|}{ Woodchopper Canyon terranes } & \\
\hline DH91-K24d & Biederman & ss/argillite & -2.9 & 17.7 & \\
\hline MJ90-K37c & Biederman & ss/argillite & -9.2 & 22.4 & vein margin \\
\hline MJ90-K37c & Biederman & ss/argillite & -8.6 & 22.8 & \\
\hline MJ90-K37c & Biederman & ss/argillite & -10.3 & 22.0 & vein center \\
\hline MJ90-K80b & Biederman & ss/argillite & -6.0 & 17.9 & \\
\hline MJ90-K82e & Biederman & ss/argillite & -2.3 & 17.9 & \\
\hline MJ90-K82f & Biederman & ss/argillite & -3.8 & 17.6 & \\
\hline MJ90-K82f & Biederman & ss/argillite & -3.0 & 17.4 & \\
\hline MJ90-K82g & Biederman & ss/argillite & -3.1 & 18.0 & \\
\hline MJ90-K82h & Biederman & ss/argillite & -3.0 & 13.9 & \\
\hline MJ90-K83g & Biederman & ss/argillite & -3.7 & 17.1 & \\
\hline MJ90-K84d & Biederman & ss/argillite & -1.0 & 14.3 & intimate with quartz \\
\hline MJ90-K84d & Biederman & ss/argillite & -1.3 & 17.8 & \\
\hline MJ90-K84e & Biederman & ss/argillite & -2.8 & 17.2 & \\
\hline MJ90-K85c & Biederman & ss/argillite & -4.2 & 18.1 & \\
\hline MJ90-K85d & Biederman & ss/argillite & -2.0 & 18.4 & intimate with quartz \\
\hline MJ90-K85d & Biederman & ss/argillite & -2.2 & 18.1 & \\
\hline MJ90-K87c & Biederman & ss/argillite & -4.4 & 19.2 & \\
\hline MJ90-K87c & Biederman & ss/argillite & -2.8 & 21.1 & white calcite \\
\hline MJ90-K87c & Biederman & ss/argillite & -3.8 & 19.4 & clear calcite \\
\hline MJ90-K88e & Biederman & ss/argillite & -5.6 & 17.6 & \\
\hline MJ90-K88e & Biederman & ss/argillite & -5.5 & 19.3 & intimate with quartz \\
\hline MJ90-K88f & Biederman & ss/argillite & -3.5 & 18.2 & \\
\hline MJ90-K88g & Biederman & ss/argillite & -3.2 & 18.2 & \\
\hline MJ90-K88g & Biederman & ss/argillite & -2.8 & 18.7 & \\
\hline MJ90-K90f & Biederman & ss/argillite & -1.6 & 18.3 & intimate with quartz \\
\hline MJ90-K90g & Biederman & ss/argillite & -2.1 & 18.4 & \\
\hline MJ90-K90h & Biederman & ss/argillite & -3.8 & 18.6 & \\
\hline MJ90-K90h & Biederman & ss/argillite & -3.4 & 19.7 & \\
\hline MJ90-K90j & Biederman & ss/argillite & -4.0 & 18.9 & \\
\hline MJ90-K91d & Biederman & ss/argillite & -5.8 & 18.5 & \\
\hline MJ90-K91d & Biederman & ss/argillite & -4.8 & 20.0 & intimate with quartz \\
\hline MJ90-K91e & Biederman & ss/argillite & -2.4 & 18.3 & \\
\hline UM90-K13a & Biederman & ss/argillite & -5.5 & 28.4 & \\
\hline UM90-K24b & Glenn & shale & -1.0 & 17.3 & \\
\hline UM90-K24b & Glenn & shale & 0.3 & 20.0 & vein margin \\
\hline UM90-K24b & Glenn & shale & 0.6 & 20.2 & vein margin \\
\hline UM90-K24b & Glenn & shale & 0.5 & 19.7 & vein center \\
\hline UM90-K25b & Glenn & shale & -4.2 & 17.3 & \\
\hline UM90-K25f & Glenn & shale & -2.6 & 19.8 & \\
\hline UM90-K25f & Glenn & shale & -2.3 & 19.5 & intimate with quartz \\
\hline DH91-K20 & Woodchopper & basalt & -2.4 & 17.8 & \\
\hline DH91-K22c & Woodchopper & shale & -0.2 & 4.4 & \\
\hline DH91-K23a & Woodchopper & basalt & -3.9 & 17.7 & \\
\hline DH91-K23b & Woodchopper & basalt & -4.1 & 18.2 & \\
\hline DH91-K25b & Woodchopper & basalt & -7.6 & 20.4 & \\
\hline
\end{tabular}

from the Kandik River and Woodchopper Canyon terranes and the Tatonduk belt. A summary of their earlier work, incorporating 22 additional analyses from the present study, follows.
If all of the samples from the study area are considered collectively, the $\delta^{18} \mathrm{O}$ values of calcite veins range from 4.4 to 28.4 per mil and $\delta^{13} \mathrm{C}$ values range from -10.3 to +7.6 per mil. A comparison of isotopic data from the Tatonduk belt 
Table 3. Oxygen isotopic data for quartz in veins and whole rocks in Kandik region of east-central Alaska.

[SMOW, Standard Mean Ocean Water standard; ss, sandstone; Pza, geologic unit of Brabb and Churkin (1969)]

\begin{tabular}{lllll}
\hline Sample No. & Geologic Unit & Lithology & $\begin{array}{l}\delta^{18} \mathrm{O} \% \\
(\mathrm{SMOW})\end{array}$ & \multicolumn{1}{c}{ Comments } \\
\hline \multicolumn{5}{c}{ Tatonduk belt } \\
\hline TB90-K56d & Adams & argillite & 19.3 & vein margin \\
TB90-K56d & Adams & argillite & 20.7 & vein center \\
TB90-K56d & Adams & argillite & 15.6 & \\
MJ90-K16a & Nation River & ss/shale & 21.7 & \\
MJ90-K76c & Tindir & diamictite & 22.7 & whole-rock value \\
MJ90-K76c & Tindir & diamictite & 26.0 & \\
MJ90-K76d & Tindir & diamictite & 22.5 & intimate with calcite \\
MJ90-K77a & Tindir & basalt & 25.3 & \\
MJ90-K77a & Tindir & basalt & 25.3 & \\
\hline
\end{tabular}

\begin{tabular}{|c|c|c|c|c|}
\hline \multicolumn{5}{|c|}{ Kandik River and Slaven Dome terranes } \\
\hline MJ90-K18e & Biederman & ss/argillite & 23.5 & \\
\hline MJ90-K18f & Biederman & ss/argillite & 24.5 & \\
\hline MJ90-K18g & Biederman & ss/argillite & 22.5 & \\
\hline MJ90-K23d & Biederman & ss/argillite & 19.9 & vein margin \\
\hline MJ90-K23d & Biederman & ss/argillite & 19.4 & opposite vein margin \\
\hline MJ90-K23d & Biederman & s/argillite & 17.5 & vein center \\
\hline MJ90-K23d & Biederman & ss/argillite & 21.2 & \\
\hline MJ90-K37c & Biederman & ss/argillite & 22.4 & \\
\hline MJ90-K79a & Biederman & ss/argillite & 22.5 & \\
\hline MJ90-K79d & Biederman & ss/argillite & 22.0 & vein margin \\
\hline MJ90-K79d & Biederman & ss/argillite & 20.3 & opposite vein margin \\
\hline MJ90-K79d & Biederman & ss/argillite & 22.8 & intermediate in vein \\
\hline MJ90-K79d & Biederman & ss/argillite & 21.8 & intermediate in vein \\
\hline MJ90-K79d & Biederman & ss/argillite & 17.1 & vein center \\
\hline MJ90-K80a & Biederman & ss/argillite & 21.0 & \\
\hline MJ90-K80b & Biederman & ss/argillite & 19.6 & \\
\hline MJ90-K82f & Biederman & ss/argillite & 19.3 & \\
\hline MJ90-K83f & Biederman & ss/argillite & 18.0 & vein margin \\
\hline MJ90-K83f & Biederman & ss/argillite & 16.7 & intermediate in vein \\
\hline MJ90-K83f & Biederman & ss/argillite & 20.3 & opposite vein margin \\
\hline MJ90-K84d & Biederman & ss/argillite & 18.1 & intimate with calcite \\
\hline MJ90-K85d & Biederman & ss/argillite & 20.5 & \\
\hline MJ90-K85d & Biederman & ss/argillite & 21.3 & intimate with calcite \\
\hline MJ90-K87c & Biederman & ss/argillite & 20.9 & \\
\hline MJ90-K87c & Biederman & ss/argillite & 16.9 & whole-rock value \\
\hline MJ90-K88e & Biederman & ss/argillite & 19.6 & \\
\hline MJ90-K88e & Biederman & ss/argillite & 21.8 & intimate with calcite \\
\hline MJ90-K88g & Biederman & ss/argillite & 19.6 & \\
\hline MJ90-K90f & Biederman & ss/argillite & 20.9 & intimate with calcite \\
\hline MJ90-K90g & Biederman & ss/argillite & 22.1 & \\
\hline MJ90-K90h & Biederman & ss/argillite & 21.2 & \\
\hline MJ90-K90h & Biederman & ss/argillite & 19.3 & \\
\hline MJ90-K91d & Biederman & ss/argillite & 21.4 & \\
\hline MJ90-K91d & Biederman & ss/argillite & 22.3 & intimate with calcite \\
\hline UM90-K13a & Biederman & ss/argillite & 19.0 & whole-rock value \\
\hline MJ90-K17b & Glenn & shale & 19.4 & \\
\hline MJ90-K17d & Glenn & shale & 18.0 & vein margin \\
\hline MJ90-K17d & Glenn & shale & 20.7 & opposite vein margin \\
\hline MJ90-K17d & Glenn & shale & 17.8 & vein center \\
\hline MJ90-K17d & Glenn & shale & 20.4 & \\
\hline MJ90-K17h & Glenn & shale & 15.9 & \\
\hline UM90-K24b & Glenn & shale & 20.2 & whole-rock value \\
\hline UM90-K25f & Glenn & shale & 21.9 & intimate with calcite \\
\hline UM90-K28c & Glenn & shale & 22.4 & vein margin \\
\hline UM90-K28c & Glenn & shale & 22.1 & vein center \\
\hline UM90-K28c & Glenn & shale & 18.2 & whole-rock value \\
\hline MJ90-K14a & Keenan & quartzite & 21.0 & \\
\hline UM90-K14b & Keenan & quartzite & 22.4 & \\
\hline UM90-K78a & Keenan & quartzite & 19.3 & \\
\hline UM90-K78a & Keenan & quartzite & 18.8 & \\
\hline UM90-K94c & Pza & argillite & 18.2 & \\
\hline UM90-K94c & Pza & argillite & 20.7 & \\
\hline \multicolumn{5}{|c|}{ Step Mountains area } \\
\hline UM90-K8d & Ford Lake & shale & 26.6 & vein margin \\
\hline UM90-K8d & Ford Lake & shale & 25.8 & opposite vein margin \\
\hline
\end{tabular}

and the Kandik River and Woodchopper Canyon terranes indicates several noteworthy features (fig. 7): (1) Although the three data sets show some overlap of $\delta^{13} \mathrm{C}$ values, most veins from the Tatonduk belt are enriched in ${ }^{13} \mathrm{C}$ (average $=-0.2$ per mil) relative to those of the Kandik River and Woodchopper Canyon terranes (average $=-3.5$ per mil). (2) With one exception, calcite veins of the Kandik River and Woodchopper Canyon terranes show no consistent deviation in isotopic values as a function of the host-rock lithology or age; in other words, values from veins in basaltic rocks of the Woodchopper Volcanics (Devonian) are virtually identical to those from the Biederman Argillite (Cretaceous) and the Glenn Shale (Triassic to Cretaceous). The one exception (sample DH91-K22c, fig. 4) comes from a thin shale interval of the Woodchopper Volcanics (fig. 2); this specimen yielded the lowest $\delta^{18} \mathrm{O}$ value (4.4 per mil) and a $\delta^{13} \mathrm{C}$ value (-0.2 per mil). And (3) calcite from veins in argillites and basalts of the Tatonduk belt display consistently lower $\delta^{18} \mathrm{O}$ values than veins in Tatonduk belt limestone, sandstone, and (or) interbedded shale units. Calcite veins from the Kandik River and Woodchopper Canyon terranes generally display a much tighter isotopic clustering than vein-filling calcite in the Tatonduk belt. If we assume geologically reasonable temperature conditions at the time of vein emplacement (estimated from fluidinclusion $T_{h}$ data, vitrinite-reflectance values, and quartz-calcite oxygen-isotope thermometry), the data indicate that the pore waters that deposited calcites in the two geologic domains were isotopically distinct.

\section{OXYGEN ISOTOPE COMPOSITIONS OF CALCITE-DEPOSITING WATERS}

On the basis of measurements of vitrinite reflectance (Underwood and others, 1992, this volume) and fluid inclusion $T_{h}$ values in quartz veins, it is certain that both the range and average of paleotemperatures were quite different in the Kandik River terrane and the Tatonduk belt (fig. 3). Most of the calcite veins from the Kandik River terrane (36 of 46 samples) have $\delta^{18} \mathrm{O}$ values within the narrow range of 17 to 20 per mil (fig. 7; table 2). These values are uniformly enriched in ${ }^{18} \mathrm{O}$ (by 0.1 to 9.5 per mil) compared to whole-rock oxygen-isotope values for the enclosing host rocks (tables 2 and 3). For comparison, Magaritz and Taylor (1976) showed that carbonate veins in a wide variety of rocks from the Franciscan Complex in coastal California have 
$\delta^{18} \mathrm{O}$ values that concentrate between 14 and 16 per mil, and these data also demonstrate an enrichment in ${ }^{18} \mathrm{O}$ with respect to the whole-rock values of the host lithologies.

Ideally, we would like to have utilized $T_{h}$ values for fluid inclusions in calcite as guides to paleotemperatures of fluids in the Kandik region. However, nearly all fluid inclusions in these calcites are stretched, frequently opened, and yield unreliable, nonreproducible $T_{h}$ values. If we assume, instead, that the Kandik River terrane calcite veins were precipitated at temperatures approximately equal to the average host-rock maxima, then it is possible to calculate $\delta^{18} \mathrm{O}$ values for the parent waters responsible for the vein fillings (O'Neil and others, 1969; Friedman and O'Neil, 1977; O'Neil, 1986).

The average host-rock paleotemperature (fig. 3; based on vitrinite reflectance) for the entire Kandik River terrane is approximately $285^{\circ} \mathrm{C}$ (Underwood and others, 1992 , this volume). If the paleotemperature calculation is restricted to the cleaved rocks within the Biederman Argillite (from which most veins were collected), then the average value rises to almost $300^{\circ} \mathrm{C}$ (in fair agreement with fluid-inclusion $T_{h}$ values measured in our present study). A comparable average value for the Tatonduk belt is only $165^{\circ} \mathrm{C}$; however, this value may be inappropriate for the purposes of calculating values of $\delta^{18} \mathrm{O}_{\text {water }}$ because it includes a disproportionate concentration of data points from an aureole of elevated thermal maturity located to the southeast of the surface trace of the Glenn Creek Fault (figs. 1 and 3). We believe that this anomaly was caused by syntectonic conductive heat transfer from hanging wall to footwall (see Laughland and others, 1990; Underwood and others, this volume). If the footwall anomaly is eliminated from the calculation, then the Tatonduk belt mean drops to roughly $130^{\circ} \mathrm{C}$. We believe that a value of $150^{\circ} \mathrm{C}$ is a reasonable compromise that takes into account the possibility of slightly elevated paleotemperatures near the thrust and is in agreement with fluid-inclusion $T_{h}$ values measured in the present study.

\section{KANDIK RIVER AND WOODCHOPPER CANYON TERRANE WATERS}

Calculated $\delta^{18} \mathrm{O}_{\text {water }}$ values (using an approximate temperature of $300^{\circ} \mathrm{C}$ ) for the Woodchopper Canyon and Kandik River terrane calcite veins (excluding sample DH91-K22c ) range from 8.2 to 22.7 per mil, with a mean of 12.5 per mil (fig. 8). A $\delta^{18} \mathrm{O}_{\text {water }}$ value near 12 per mil is consistent with a metamorphic parent fluid (Sheppard, 1986); in other words, the fluids must have equilibrated isotopically with a large volume of metamorphic or sedimentary rocks at elevated temperatures and low water-to-rock ratios (Valley, 1986). Similar calculations of $\delta^{18} \mathrm{O}_{\text {water }}$ values in the Catalina Schist of California yielded average values of about 13 per mil for both greenschist facies and blueschist-facies units (Bebout and Barton, 1989). We suggest that dehydration reactions within pelitic and basaltic rocks during lowermost greenschist-facies metamorphism (for example, see Valley, 1986) provided the source for fluids moving through the Kandik River and Woodchopper Canyon terranes.

\section{TATONDUK BELT WATERS}

The extreme scatter of $\delta^{18} \mathrm{O}$ values in Tatonduk belt calcite veins (fig. 7) indicates that the fluids' oxygen-isotope compositions likely were affected by several types of rocks, including marine carbonate rocks, which typically yield relatively high $\delta^{18} \mathrm{O}$ values $(25 \pm 2$ per mil, Keith and Weber, 1964). Using a temperature of $150^{\circ} \mathrm{C}$, calculated $\delta^{18} \mathrm{O}_{\text {water }}$ values for calcite veins of the Tatonduk belt are -6.5 to +13.7 per mil, with an average of 5.5 per mil (fig. 8). These estimates are significantly depleted in ${ }^{18} \mathrm{O}$ relative to the $\delta^{18} \mathrm{O}_{\text {water }}$ values estimated for the Kandik River and Woodchopper Canyon terranes to the west (fig. 8). Assuming a constant temperature of calcite vein formation, the Tatonduk belt results are consistent with precipitation dominantly from less evolved meteoric waters whose isotopic compositions were attained through interaction with carbonate, siliciclastic, and basaltic rocks under moderate to high water-to-rock ratio conditions

Figure 6. Stable-isotope values for veins in Tatonduk belt and Kandik River, Woodchopper Canyon, and Slaven Dome terranes of Churkin and others (1982). $A, \delta^{13} \mathrm{C}$ values for calcite veins; $B, \delta^{18} \mathrm{O}$ values for calcite veins; $C, \delta^{18} \mathrm{O}$ values for quartz veins. TKs and Pza, geologic units of Brabb and Churkin (1969). Paired arrows along faults show relative motion; barbs along faults show downthrown side. 

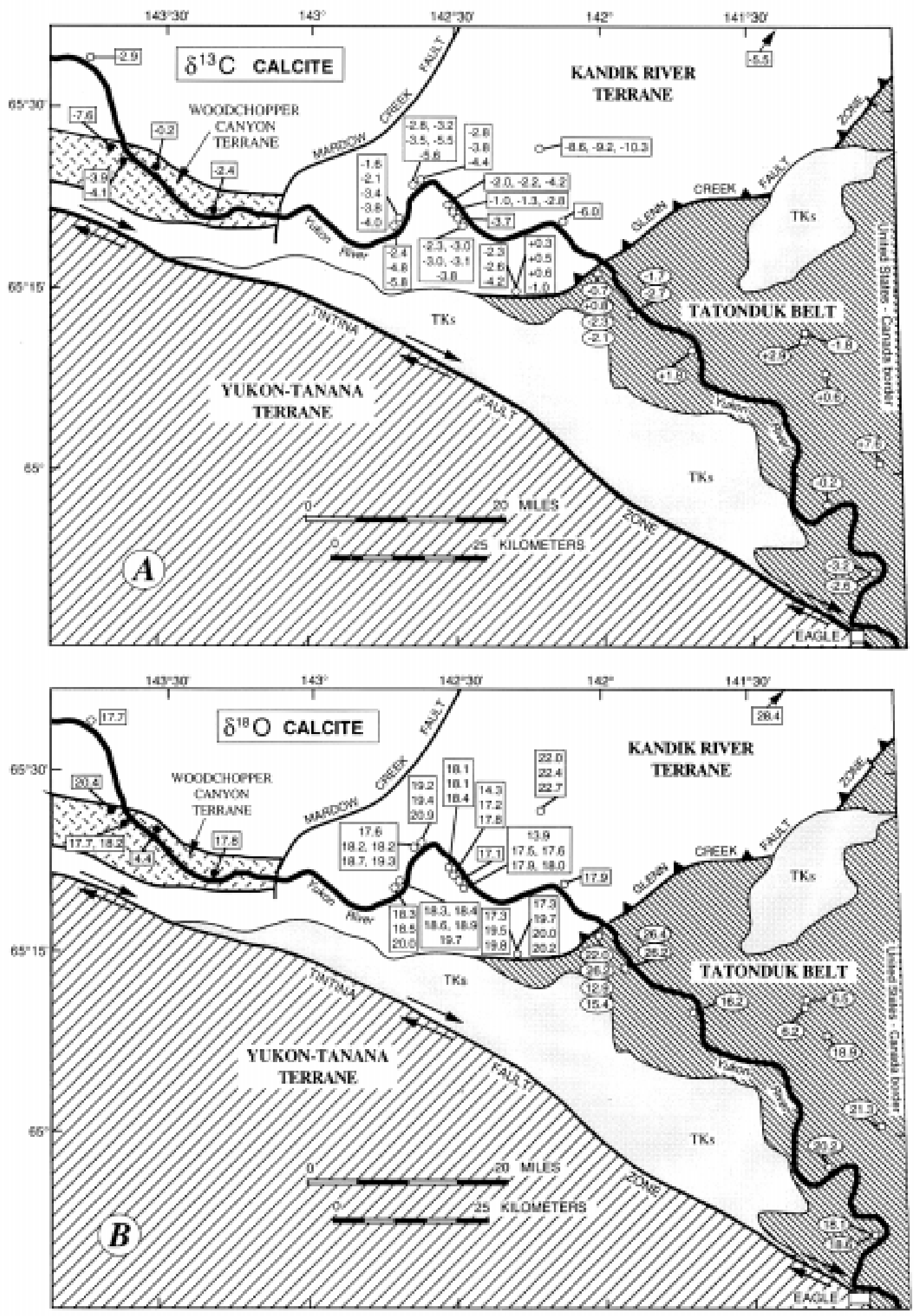
(Sheppard, 1986). Because similar $\delta^{18} \mathrm{O}_{\text {water }}$ values are associated with host formations containing interbeds of limestone and shale, chert and shale, and sandstone and shale, we suggest that an open system of vein-forming fluids probably crossed many of the formational boundaries within the Tatonduk belt stratigraphy.

The lowest $\delta^{18} \mathrm{O}$ values for calcite veins come from mudrock and chert-shale units (Adams Argillite and Road River Formation), where low formation permeabilities evidently inhibited significant isotopic exchange between fluids and the host rock. Thus, the ${ }^{18} \mathrm{O}$-depleted signature of the source meteoric-water reservoir was dominantly preserved in these strata. Also, at temperatures below $150^{\circ} \mathrm{C}$, exchange reactions are controlled by kinetics (O'Neil, 1986); isotopic equilibration with the silicic host rocks under these circumstances is unlikely.

The highest $\delta^{18} \mathrm{O}$ values for calcite veins (26.2 to 26.4 per mil) are from basement rocks of the Tindir Group.
The origin of these veins is problematic, as they may record an earlier fluid history, representing hydrothermal veining prior to deposition of Paleozoic sediments of the Tatonduk belt. Such an interpretation is supported by abnormally high $T_{h}$ values for fluid inclusions in associated quartz.

The single vein sample from shale of the Woodchopper Canyon terrane probably precipitated during a later stage, lower temperature emplacement event. This sample has a $\delta^{13} \mathrm{C}$ value of -0.2 per mil, which is very close to the average value for the Tatonduk belt. In addition, if a lower paleotemperature of $150^{\circ} \mathrm{C}$ is used to calculate the $\delta^{18} \mathrm{O}_{\text {water }}$ value for this specimen, it yields a $\delta^{13} \mathrm{C}$ value of $-8.3 \mathrm{per}$ mil, which also indicates a relatively unexchanged meteoric water. This vein probably precipitated late in the paragenetic history.

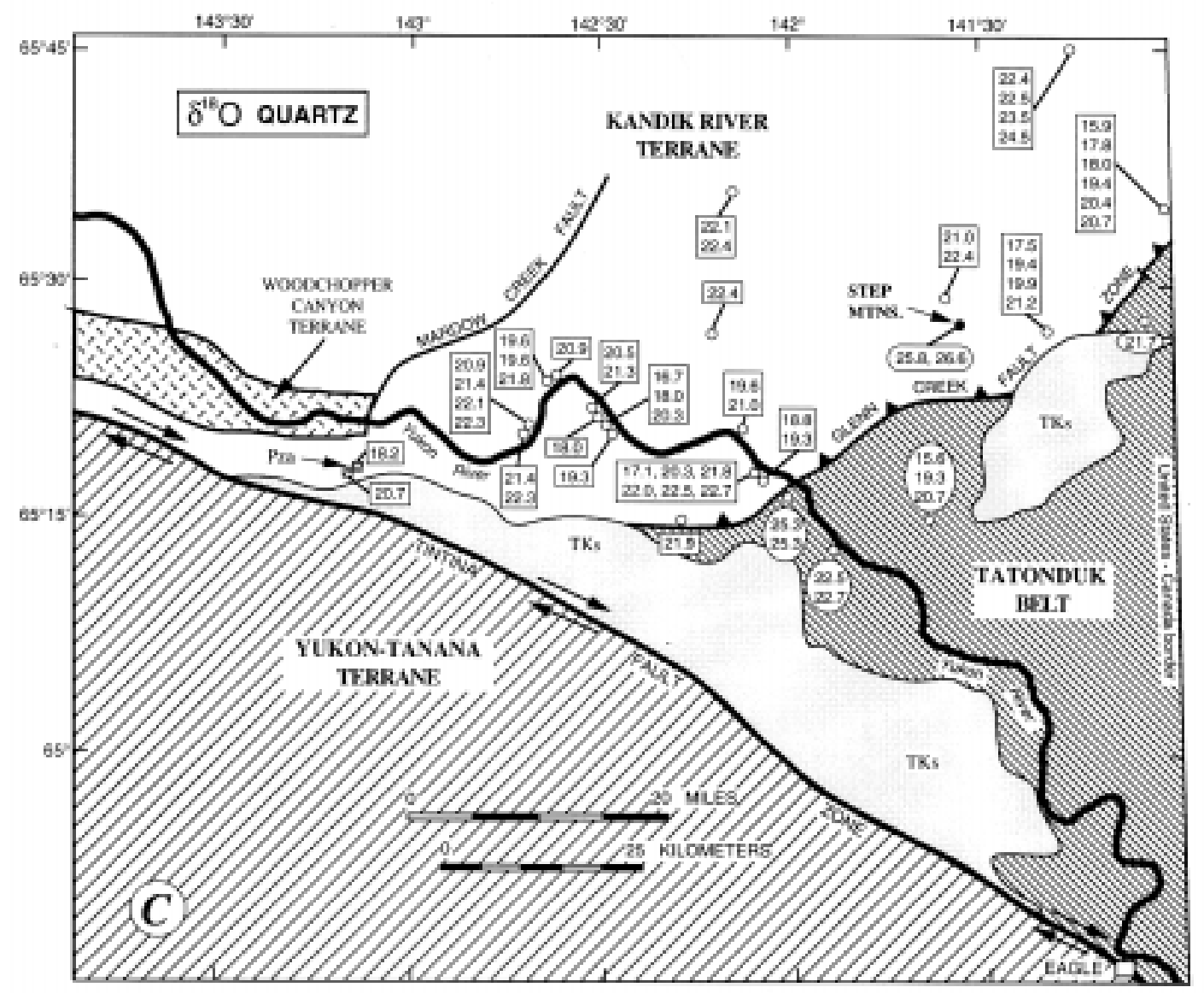

Figure 6. Continued. 


\section{CARBON ISOTOPES}

The $\delta^{13} \mathrm{C}$ values for calcite veins in the Kandik River and Woodchopper Canyon terranes (average $=-3.5$ per mil) are compatible with a fluid source that incorporated oxidized carbon from a mixed source (marine limestone with minor input from degradation of organic carbon). The enrichment of ${ }^{13} \mathrm{C}$ in calcite veins from the Tatonduk belt (average $\delta^{13} \mathrm{C}=-0.2$ per mil) may be due to lower temperatures of calcite-vein formation (Emrich and others, 1970).

If we again assume average calcite depositional temperatures of $150^{\circ}$ and $300^{\circ} \mathrm{C}$ for the Tatonduk belt and the composite Kandik River and Woodchopper Canyon terranes, respectively, then it is possible to calculate the $\delta^{13} \mathrm{C}$ values of dissolved $\mathrm{CO}_{2}$ in equilibrium with calcite (Friedman and O'Neil, 1977). Calculated average $\delta^{13} \mathrm{C}$ values of dissolved $\mathrm{CO}_{2}$ are -1.4 per mil for the Kandik River and Woodchopper Canyon terranes and -1.7 per mil for the Tatonduk belt. These values indicate that calcite-depositing fluids in each terrane contained dissolved $\mathrm{CO}_{2}$ of similar isotopic composition.

The highest $\delta^{13} \mathrm{C}$ value (7.6 per mil) comes from a calcite vein extracted from a shale unit of the Tindir Group. Although this carbon isotope signature could have been affected by the presence of ${ }^{13} \mathrm{C}$-enriched interbedded carbonate rocks, another possible cause is the presence of methane. Methane concentrates ${ }^{12} \mathrm{C}$ relative to oxidized carbon species and thus causes the coexisting $\mathrm{CO}_{2}$ in a mixed-carbon fluid to become enriched in ${ }^{13} \mathrm{C}$; precipitation of calcite from the dissolved $\mathrm{CO}_{2}$ component in this type of fluid would cause an increase in $\delta^{13} \mathrm{C}$ values. In contrast, oxidation of methane will result in carbonates depleted in ${ }^{13} \mathrm{C}$ (for example, see Hudson, 1977; Ritger and others, 1987). Despite the presence of methanerich fluid inclusions in some quartz veins in the Kandik River terrane, there is no evidence to indicate that any calcite in veins of the Kandik study area was precipitated directly from

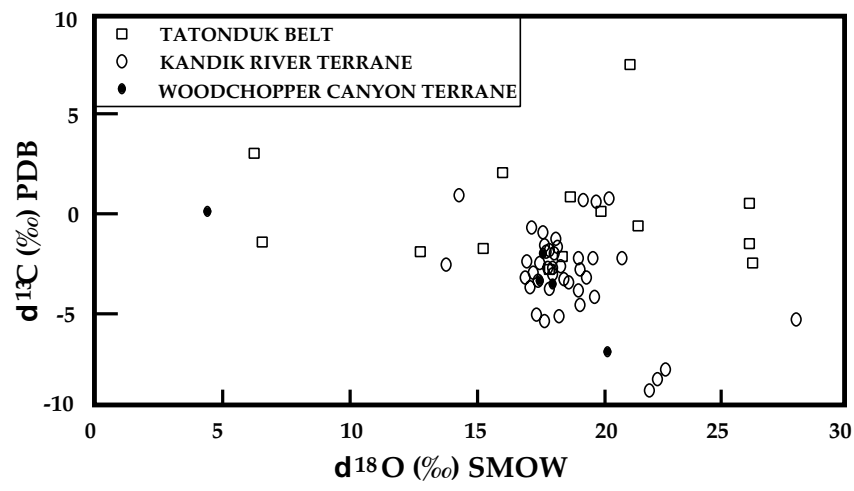

Figure 7. $\delta^{13} \mathrm{C}$ values (relative to the Pee Dee Belemnite (PDB) standard) and $\delta^{18} \mathrm{O}$ values (relative to Standard Mean Ocean Water (SMOW)) for vein-filling calcite extracted from rocks of Tatonduk belt, Kandik River terrane, and Woodchopper Canyon terrane, east-central Alaska. See table 1 for values and identification of host lithologies. a ${ }^{13} \mathrm{C}$-depleted fluid reservoir containing abundant hydrocarbons or their oxidized equivalents.

\section{OXYGEN-ISOTOPE COMPOSITIONS OF QUARTZ}

If all of the samples from the study area are considered collectively, the $\delta^{18} \mathrm{O}$ values of quartz veins range from 15.6 to 26.6 per mil. A comparison of the isotopic data from the Tatonduk belt, the Kandik River terrane, and the Slaven Dome terrane indicates several noteworthy features (table 3): (1) Even though the three data sets show significant overlap of $\delta^{18} \mathrm{O}$ values, quartz veins from the Tatonduk belt generally have higher $\delta^{18} \mathrm{O}$ values (range, 15.6 to 25.3 per mil; mean, 21.7 per mil) relative to those of the Kandik River terrane (range, 15.9 to 24.5 per mil; mean, 20.7 per mil) and the Slaven Dome terrane (range, 18.2 to 20.7 per mil; mean, 19.5 per mil). (2) Like calcite, quartz in veins from the Kandik River terrane shows no consistent deviation in isotopic values as a function of the host-rock lithology or age. (3) Quartz veins in basement rocks of the Tatonduk belt (Tindir Group) display consistently higher $\delta^{18} \mathrm{O}$ values (21.7 to 25.3 per mil) than quartz veins hosted in the overlying Paleozoic strata (15.6 to 20.8 per mil). (4) The highest $\delta^{18} \mathrm{O}$ values for quartz veins in the Kandik region (25.8 and 26.6 per mil) are from a sample locality (sample UM90-K8d) within the Step Mountain area (fig. 1), where terrane designation is in dispute and fluid inclusions are abnormally saline. And (5) The lowest $\delta^{18} \mathrm{O}$ values for quartz veins within the Kandik River terrane and the Tatonduk belt occur proximal to the Glenn Creek Fault (fig. $6 C$ ). We believe this to be coincidental, as fluid inclusions in these veins indicate that they were formed from chemically and thermally distinct fluids prior to thrusting.

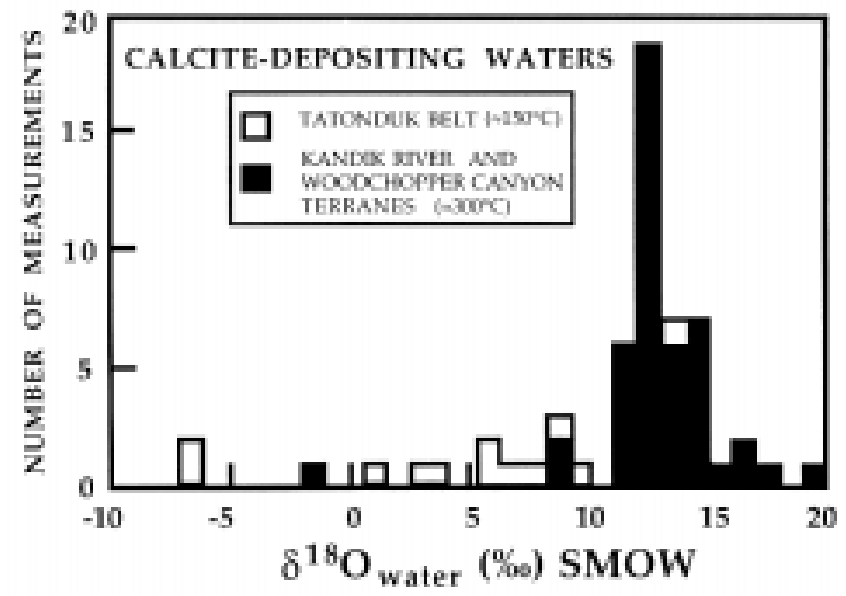

Figure 8. Calculated $\delta^{18} \mathrm{O}_{\text {water }}$ values (relative to Standard Mean Ocean Water (SMOW)) for calcite veins in Tatonduk belt and composite Kandik River and Woodchopper Canyon terranes of eastcentral Alaska. Calculations follow technique outlined by O'Neil and others (1969) and Friedman and O’Neil (1977). 


\section{QUARTZ-CALCITE OXYGEN-ISOTOPE THERMOMETRY}

Textures of many veins in the Kandik region indicate that quartz and calcite were not coprecipitated, but were deposited sequentially, with calcite forming later than quartz. Nevertheless, seven quartz-calcite veins ( 6 from the Kandik River terrane, 1 from the Tatonduk belt) have intimate intergrowths of quartz and calcite, which may be indicative of coprecipitation. These veins were analyzed in detail for their use as quartz-calcite oxygen-isotope thermometers.

$\Delta^{18} \mathrm{O}_{\text {quartz-calcite }}$ values from the Kandik River terrane range from 3.7 to 2.3 per mil and correspond to apparent equilibrium depositional temperatures of $270^{\circ}$ to $375^{\circ} \pm 30^{\circ} \mathrm{C}$ (Friedman and O'Neil, 1977). These temperatures are $40^{\circ}$ to $70^{\circ} \mathrm{C}$ higher than $T_{h}$ values for fluid inclusions in quartz from the same veins. If these temperature differences represent the pressure correction to the $T_{h}$ values, they would correspond to pressures of approximately 500 to 800 bars at the time of vein emplacement (Potter, 1977).

The lone $\Delta^{18} \mathrm{O}_{\text {quartz-calcite }}$ value for the Tatonduk belt is 3.3 per mil and corresponds to an apparent equilibrium depositional temperature of $290^{\circ} \mathrm{C}$, a temperature which is consistent with this vein's occurrence in host rocks of the Tindir Group in which high-temperature fluid inclusions are found $\left(T_{h}=225^{\circ}\right.$ to $\left.340^{\circ} \mathrm{C}\right)$.

\section{OXYGEN ISOTOPE COMPOSITIONS OF QUARTZ-DEPOSITING WATERS}

If we assume reasonable temperature conditions at the time of vein emplacement, it is possible to calculate $\delta^{18} \mathrm{O}$ values for the parent waters responsible for the quartz vein fillings (Clayton and others, 1972). By doing so, we can demonstrate whether or not the pore waters that deposited quartz veins in the Kandik River terrane were distinct isotopically from those in Paleozoic rocks of the Tatonduk belt.

\section{KANDIK RIVER AND SLAVEN DOME TERRANE WATERS}

If we assume that quartz veins in the Kandik River terrane were precipitated at fluid temperatures approximately equal to the average terrane maximum for the host rocks (determined by vitrinite reflectance to be approximately $300^{\circ} \mathrm{C}$; Underwood and others, 1992, this volume), then calculated $\delta^{18} \mathrm{O}_{\text {water }}$ values range from 8.5 to 17.1 per mil, with a mean of 13.3 per mil (fig. 9). If $T_{h}$ values for fluid inclusions and quartzcalcite oxygen isotope fractionation estimates of fluid temperature are used instead, then calculated $\delta^{18} \mathrm{O}_{\text {water }}$ values range from 13.2 to 16.6 per mil, with a mean of 14.8 per mil (fig. 9). These calculated $\delta^{18} \mathrm{O}_{\text {quartz-depositing water }}$ values are very similar to $\delta^{18} \mathrm{O}_{\text {calcite-depositing water }}$ values from the Kandik River terrane (range, 8.2 to 16.7 per mil; mean, 12.5 per mil; fig. 8 ), indicating that both calcite and quartz veins in the Kandik River terrane formed from fluids of similar temperatures and isotopic compositions.

If we assume that the quartz veins in unit Pza were precipitated at temperatures approximately equal to their average terrane maximum (determined by vitrinite reflectance to be approximately $300^{\circ} \mathrm{C}$, fig. 3; Underwood and others, 1992 , this volume), calculated $\delta^{18} \mathrm{O}_{\text {water }}$ values are 10.8 to 13.3 per mil, similar to those calculated for the Kandik River terrane.

A $\delta^{18} \mathrm{O}_{\text {water }}$ value of approximately 13 per mil is consistent with a metamorphic parent fluid (Sheppard, 1986); in other words, the fluids must have equilibrated isotopically with a large volume of metamorphic and (or) sedimentary rocks at elevated temperatures and low water-to-rock ratios (Valley, 1986). We suggest that dehydration reactions, mostly within pelitic and perhaps local basaltic rocks during lowermost greenschist-facies metamorphism, provided the source for both quartz- and calcite-depositing fluids moving through the Kandik River terrane.

\section{TATONDUK BELT WATERS}

Because of the disparity of fluid-inclusion $T_{h}$ values between various quartz veins hosted in Paleozoic $\left(120^{\circ}\right.$ to $\left.140^{\circ} \mathrm{C}\right)$ and Tindir Group $\left(225^{\circ}\right.$ to $\left.340^{\circ} \mathrm{C}\right)$ rocks in the Tatonduk belt, their calculated $\delta^{18} \mathrm{O}_{\text {water }}$ values will be treated separately. If $T_{h}$ values for fluid inclusions are used as estimates of fluid temperature at the time of vein precipitation, then calculated $\delta^{18} \mathrm{O}_{\text {quartz-depositing water }}$ values for quartz veins in Paleozoic rocks range from -1.4 to +5.7 per mil, with a mean of 2.6 per mil (fig. 9). These calculated $\delta^{18} \mathrm{O}_{\text {quartz-depositing water }}$ values fall within the lower portion of the range for $\delta^{18} \mathrm{O}_{\text {calcite-depositing waters }}$ values from the Tatonduk belt (range,

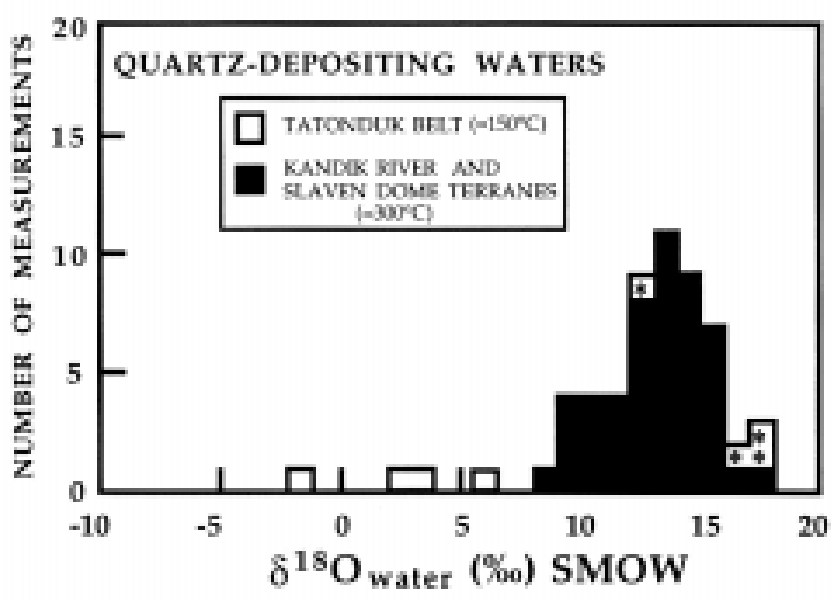

Figure 9. Calculated $\delta^{18} \mathrm{O}_{\text {water }}$ values (relative to Standard Mean Ocean Water (SMOW)) for quartz veins in Tatonduk belt and Kandik River terrane of east-central Alaska. Calculations follow technique outlined by Clayton and others (1972) and Friedman and O'Neil (1977). Asterisk (*), veins hosted in Tindir Group rocks. 
-6.5 to +13.7 per mil; mean, +5.5 per mil; fig. 8 ), indicating that both calcite and quartz veins formed from fluids of comparable temperatures and roughly similar isotopic compositions. These Tatonduk belt $\delta^{18} \mathrm{O}_{\text {water }}$ values, furthermore, are consistent with precipitation from variously evolved meteoric waters, whose isotopic compositions were attained through interaction with carbonate, siliciclastic, and basaltic rocks under moderate to high water-to-rock ratio conditions (see Sheppard, 1986, for comparison).

Calculated $\delta^{18} \mathrm{O}$ values for quartz veins in basement rocks of the Tindir Group (range, 12.0 to 17.5 per mil; mean, 15.8 per mil; fig. 9) are unlike those for quartz veins hosted in Paleozoic rocks in the Tatonduk belt ( -1.4 to +5.7 per mil; fig. 9). Fluid inclusions in quartz veins hosted in Tindir Group rocks preserve higher temperatures $\left(T_{h}=225^{\circ}\right.$ to $340^{\circ} \mathrm{C}$; fig. 5) compared to fluid inclusions in quartz veins hosted in Paleozoic rocks $\left(T_{h}=120^{\circ}\right.$ to $140^{\circ} \mathrm{C}$, fig. 5). The differences in fluid temperatures and isotopic compositions indicate a fundamental difference in the sources and migrational histories for fluids depositing quartz veins in the Tindir Group and Paleozoic rocks of the Tatonduk belt. We believe that quartz veins hosted in the Tindir Group preserve a higher temperature emplacement event that preceded burial beneath the Paleozoic succession. The $\delta^{18} \mathrm{O}_{\text {quartz-depositing water }}$ values for these quartz veins hosted in basement rocks (12.0 to 17.5 per mil) are not due to sea floor hydrothermal convection (basalt-seawater interaction), and similar fluids are present in quartz veins hosted in shale, diamictite, and basalt. These $\delta^{18} \mathrm{O}_{\text {quartz-depositing water }}$ values are more likely the result of Proterozoic to early Cambrian low-temperature metamorphism of continental basement.

The $\delta^{18} \mathrm{O}_{\text {quartz-depositing water }}$ values for quartz veins hosted in Tindir Group rocks are similar to some of the $\delta^{18} \mathrm{O}_{\text {quart-depositing water }}$ values for fluids that precipitated veins in the Kandik River terrane. However, fluid inclusions in the Tindir Group veins are significantly less saline (approximately seawater salinity) as compared to those in the Kandik River terrane ( 2 to 3 times seawater salinity). Thus, although hightemperature veins in each domain formed from isotopically similar fluids, the fluids were not the same.

\section{STEP MOUNTAINS AREA WATERS}

The $\delta^{18} \mathrm{O}$ values for Paleozoic rocks in the Step Mountains area (locality UM90-K8d, figs. 1 and 4) are 14.4 and 15.2 per mil. These values are similar to the values calculated for both the quartz veins of the Kandik River terrane and the quartz veins hosted in rocks of the Tindir Group. The similarity of $\delta^{18} \mathrm{O}_{\text {quartz-depositing water }}$ values and the unique high-salinity nature of their fluid inclusions do not allow us to resolve the enigmatic thermotectonic history of the Step Mountains area.

\section{TECTONIC EVOLUTION}

Fluid-inclusion microthermometry and isotopic compositions of calcite- and quartz-depositing fluids in the Kandik River terrane and the Tatonduk belt provide important constraints on models of regional tectonic evolution (fig. 10) (for example, see Dover, 1990; Laughland and others, 1990; Howell and others, 1992). Tatonduk belt calcite veins produce a wide scatter in both $\delta^{13} \mathrm{C}$ and $\delta^{18} \mathrm{O}$ values, whereas the Kandik River terrane data cluster more tightly, with average values of about $\delta^{18} \mathrm{O}=+18$ per mil and $\delta^{13} \mathrm{C}=-4$ per mil. There is little overlap between the two data sets, particularly if one calculates the $\delta^{18} \mathrm{O}$ values of the parent waters from which the calcite veins precipitated (fig. 8). Thus, calcite veins in the Tatonduk belt did not share a common emplacement history with veins of the Kandik River terrane; these two terranes, moreover, never shared common fluid reservoirs or common pathways of fluid migration.

Oxygen-isotope compositions of vein-filling quartz, together with fluid-inclusion $T_{h}$ values, indicate that parent fluids in the Kandik River terrane $\left(\delta^{18} \mathrm{O}_{\text {water }}=13.2\right.$ to 16.6 per mil) were enriched in ${ }^{18} \mathrm{O}$ relative to fluids that moved through Paleozoic strata of the Tatonduk belt $\left(\delta^{18} \mathrm{O}_{\text {water }}=-1.4\right.$ to +3.8 per mil). Quartz veins hosted in Proterozoic rocks of the Tatonduk belt (Tindir Group) preserve a higher temperature event $\left(T_{h}=225^{\circ}\right.$ to $\left.340^{\circ} \mathrm{C}\right)$ that predates the terrane amalgamation history. These veins were not the result of sea floor hydrothermal convection, and similar fluids are present in quartz veins hosted in shale, diamictite, and basalt. They are more likely the result of Proterozoic to early Cambrian low-temperature metamorphism of continental basement. Calculated $\delta^{18} \mathrm{O}_{\text {water }}$ values for fluids precipitating the quartz veins hosted in Tindir Group rocks (16.1 to 17.5 per mil) are similar to those that precipitated veins in the Kandik River terrane. However, fluid inclusions in quartz veins hosted in Tindir Group rocks are significantly less saline (approximately seawater salinity) than those in the Kandik River terrane (2 to 3 times seawater salinity). Although high-temperature veins in each domain formed from isotopically similar fluids, the fluids clearly were not the same.

The fluid reservoir for the Kandik River terrane equilibrated with a large volume of metasedimentary and volcanic rocks at elevated temperatures $\left(T_{h} \geq 295^{\circ} \mathrm{C}\right)$ and low water-to-rock ratios. Fluids within this geologic domain probably were derived during early Albian orogenesis from dehydration reactions of mostly pelitic rocks and local basalt under conditions of lowermost greenschist-facies metamorphism (fig. 10B). Geothermal gradients probably were between $35^{\circ}$ and $60^{\circ} \mathrm{C} / \mathrm{km}$ during peak heating, but the exact source of this heat flux remains unknown (Underwood and others, this volume).

Typical veins within Paleozoic rocks of the Tatonduk belt, in contrast, precipitated at much lower temperatures $\left(T_{h}=120^{\circ}\right.$ to $\left.140^{\circ} \mathrm{C}\right)$ from less evolved, meteoric waters, 
which most likely attained their isotopic compositions under conditions of moderate to high water-to-rock ratios and modest amounts of interaction with intrabasinal carbonate, siliciclastic, and volcanic rocks. The exchange of fluids across the Glenn Creek Fault Zone (fig. 1) appears to have been very limited. Fluid inclusions and stable isotopes, moreover, provide supporting evidence for emplacement of a hot Kandik River terrane hanging wall over a cooler Tatonduk belt footwall during the late Albian to Cenomanian (fig. 10C).

Calcite veins of the Kandik River terrane that are hosted in basaltic rocks of the Woodchopper Volcanics (Devonian) are virtually identical to those in the Biederman Argillite (Early
Cretaceous). Quartz veins in unit Pza (Paleozoic) of the Slaven Dome terrane and in quartz veins in the Kandik River terrane were precipitated from isotopically similar fluids. This evidence strongly supports the idea that these tectonostratigraphic units were linked structurally during the Early Cretaceous prior to the peak-heating and fluid-migration events (fig. 10A). Most of the calcite and quartz veins in the Biederman Argillite are aligned at high angles to pressure-solution cleavage; precipitation occurred mostly within extension fractures in the sandstone interbeds, rather than within the pelitic rocks. Because of this, we believe that vein emplacement was broadly synchronous with the formation of cleavage during the early Albian (fig. 10B). If fluid migration had occurred long after low-temperature metamorphism, then we would expect to see evidence of fracture

\section{THERMOTECTONIC HISTORY OF THE KANDIK REGION}

A

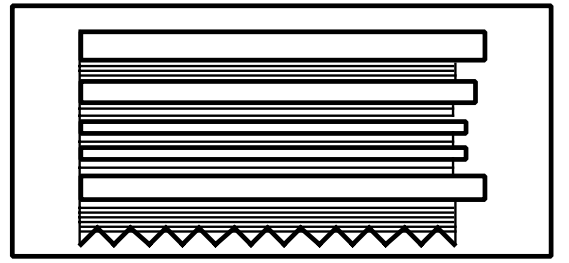

B

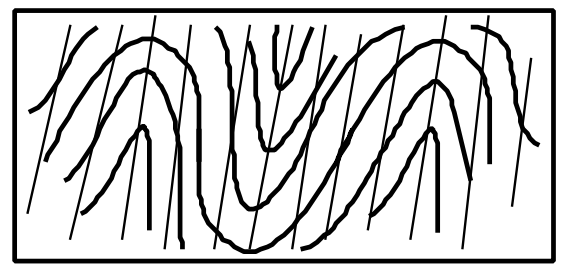

C

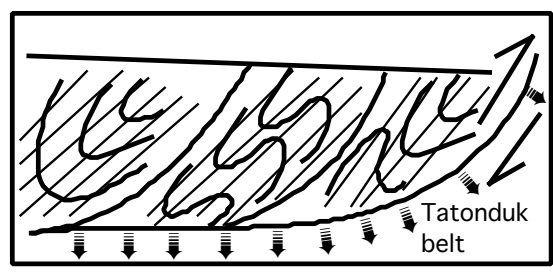

D

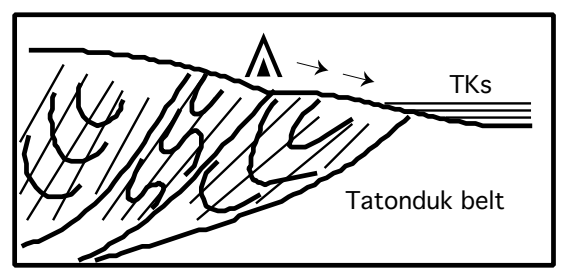

E

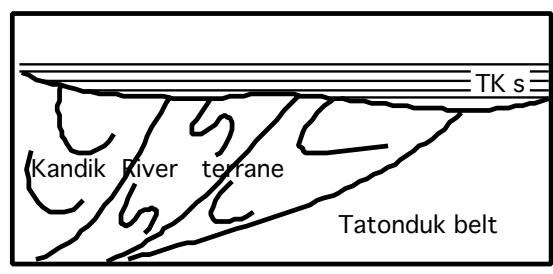

140-110 Ma (Early Cretaceous)

Deposition of Kandik Group deep-marine turbidites

\section{0-100 Ma (early Albian)}

Peak heating event under high geothermal gradients; organic metamorphism; folding, cleavage, and dehydration; veins form at 500-800 bars (near hydrostatic pressure).

\section{0-95 Ma (Albian to Cenomanian)}

Uplift and cooling begins; initiation of terrane amalgamation via Glenn Creek fault; structural thickening by imbrication; methane-bearing inclusions occur at $800-1,500$ bars (lithostatic pressure); development of footwall aureole by conduction across fault (dashed arrows).

\section{5-75 Ma (Cenomanian to Campanian)}

Continued uplift, cooling, and erosion; syntectonic deposition of basal sediments of unit TKs of Brabb and Churkin (1969).

\section{5-30 Ma (Maastrichtian to Oligocene) \\ Progradation of unit TKs of Brabb and Churkin (1969); fluvial/alluvial deposition; minor late-stage deformation}

Figure 10. Schematic cartoons to illustrate thermotectonic history of Kandik region, east-central Alaska. See text for discussion. TKs, geologic unit TKs of Brabb and Churkin (1969). 
propagation through both sandstone beds and cleaved pelites. We see no evidence for preferential concentration of veins along pathways of enhanced permeability, such as fault zones. The density of veining is not high enough to indicate huge volumes of migrating fluids as a heat source to drive metamorphism, unless multipass circulation was maintained for an extended period of time. Fluid movement and vein precipitation, therefore, were probably byproducts of regional metamorphism, not the cause.

The absolute age of vein precipitation in the Kandik River terrane, and its relative timing with respect to veins of the Tatonduk belt, remain debatable (fig. 10). Peak heating of the Kandik Group evidently occurred during the Albian. The youngest fossils within the Biederman Argillite of our study area are late Neocomian (Miyaoka, 1990). The Kathul Graywacke does not contain age-diagnostic fossils, but tentative stratigraphic correlations with rocks to the east of our study area indicate an early Albian age (Brabb and Churkin, 1969; Howell and Wiley, 1987; Underwood and others, 1989). Metamorphism, cleavage formation, and veining definitely occurred before the Late Cretaceous and Tertiary deposition of unit TKs, which overlies the Kandik River terrane and Tatonduk belt along an angular unconformity and which was affected by only mild deformation and diagenesis.

In Paleozoic strata of the Tatonduk belt, fluid flow and local vein formation definitely occurred at lower temperatures than in the Kandik River terrane, with various degrees of isotopic exchange between fluids and host rocks. Veins of the Tatonduk belt could have precipitated long before the two terranes were juxtaposed along the Glenn Creek Fault Zone; alternatively, some or all of the veins may have formed late in the diagenetic history of Paleozoic strata, after the hanging wall of the thrust system had cooled. We favor the former interpretation (fig. 10C), for the following three reasons: (1) Except for the narrow thermal anomaly beneath the Glenn Creek Fault (figs. 1, 3, and 10C), vitrinite reflectance within the Tatonduk belt was not reset to higher values during the Cretaceous orogenic event (Laughland and others, 1990; Underwood and others, 1992, this volume). All of the veining was not necessarily synchronous with peak heating, but because we find only local evidence for a syntectonic thermal overprint, burial temperatures within most of the Tatonduk belt probably reached peak values owing to passive first-cycle depositional overburden. Veins from one anomalous site in the Nation River Formation (locality MJ90K59, fig. 4) may represent an exception. (2) There is no evidence to suggest that hot fluids escaped the Kandik River terrane and penetrated downdip into the Tatonduk belt. In fact, during field traverses, we did not recognize obvious increases in the spatial density of veining near the fault zone in either the hanging wall or the footwall. More importantly, there are no isotopic or fluid-inclusion $T_{h}$ anomalies associated with veins in rocks on either side of the Glenn Creek Fault, and there is no detectable gradient in isotopic or fluid-inclusion
$T_{h}$ values with distance from the fault. One or more of these occurrences might be expected on a widespread basis if the fault had served as a major pathway of syntectonic fluid movement. Instead, isotopic compositions and fluid-inclusion $T_{h}$ values change abruptly across the fault zone. However, one local exception that could represent a fluid anomaly in the upper part of the footwall, now exposed as a fenster, is associated with the Step Mountains area. Fluids in this anomalous area could have been associated directly with thrust movement and terrane amalgamation, but this is largely conjecture based on only one datum. (3) If widespread fluid migration had occurred after thrusting, then one might expect extensive cross-cutting of multiple-phase Kandik River vein sets owing to updip penetration of a later stage, lower temperature "plumbing" system from the underlying Tatonduk strata. There is no evidence to support this idea on a regional scale. Instead, we note that veins in basalt of the Tindir Group just to the southeast of the Glenn Creek Fault are isotopically distinct with respect to veins in the structurally overlying Glenn Shale and Biederman Argillite. We found only one unusual vein sample (DH91-K22c; $\delta^{18} \mathrm{O}=4.4$ per mil) from shale of the Woodchopper Canyon terrane that probably did precipitate very late in the thermal history of the region, during the migration of meteoric fluids through the section.

Following vein formation, methane-rich fluids were trapped along healed fractures in quartz veins in the Kandik River terrane (fig. 10C). These fluid inclusions indicate fluid pressures of between approximately 800 and 1,500 bars at the time of methane entrapment, corresponding to depths of approximately 3 to $6 \mathrm{~km}$ and 8 to $15 \mathrm{~km}$, respectively, assuming purely lithostatic or hydrostatic pressure regimes for the fluid phase. Pressure estimates for methane-bearing fluid inclusions (800 to 1,500 bars) are higher than those calculated for quartz vein emplacement (500 to 800 bars) and may indicate: (1) the Kandik River terrane was buried more deeply (tectonically through thrust imbrication) following vein emplacement and prior to methane entrapment; and (or) (2) the pressure conditions shifted from a more open hydrostatic system toward a more lithostatic (overpressured) regime as a result of fracture sealing by quartz-calcite vein deposition (fig. $10 C)$.

The Early Cretaceous Kandik Group probably underwent unroofing and rapid uplift just prior to and during the accumulation of basal deposits of unit TKs (fig. $10 D)$. Apatite-fission-track data for the Kathul Graywacke fix the time of cooling of the Kandik River terrane through a temperature of about $100^{\circ}$ to $125^{\circ} \mathrm{C}$ to be of Albian age ( maximum pooled age $=96 \mathrm{Ma}$; Underwood and others, this volume). Uplift and cooling continued into the Campanian (minimum pooled age $=80 \mathrm{Ma}$ ). The oldest fossils in overlying unit TKs are Late Cretaceous in age (Dover and Miyaoka, 1988; Miyaoka, 1990), and fluvial/alluvial deposition continued into Eocene and Oligocene time (fig. 
$10 E)$. Coal lenses and dispersed organic matter within unit TKs are consistent with low paleotemperatures, generally below $100^{\circ} \mathrm{C}$ (fig. 3). We suggest that the basal deposits of unit TKs were derived from erosion of the orogenic highlands during latest Albian to Cenomanian time (fig. $10 D)$. Thus, the Kandik River terrane experienced hydrothermal vein emplacement at temperatures up to $300^{\circ} \mathrm{C}$, significant burial and introduction of methane, and subsequent uplift and unroofing all within a narrow time window of approximately 110 to $95 \mathrm{Ma}$ (fig. 10).

\section{CONCLUSIONS}

Fluid-inclusion and stable-isotope data from quartz and calcite veins amplify previous interpretations of the regional thermal structure of the Kandik region of east-central Alaska, particularly with regard to the emplacement of a hot Kandik River allochthon over cooler footwall sequences of the Tatonduk belt. Fluid reservoirs in these two domains were not connected during the principal phases of vein precipitation, and most of the Kandik River veins were formed in Albian time before the tectonostratigraphic domains were juxtaposed along the Glenn Creek Fault Zone. Similarities in isotopic data support the idea that the Woodchopper Canyon, Slaven Dome, and Kandik River terranes were amalgamated prior to vein precipitation. The heat source and location of Albian metamorphism remain uncertain. The Tatonduk belt strata may have moved only slightly with respect to the rifted edge of Precambrian North America. Conversely, all terranes to the west of these strata are clearly allochthonous in terms of thermal and hydrogeologic evolution. Pronounced spatial contrasts in paleogeothermal gradients and fluid reservoirs require that significant distances of tectonic transport toward the southeast followed culmination of the Albian heating event. These results demonstrate the utility of combining fluid inclusions and stable-isotope geochemistry in deciphering the geodynamic histories of neighboring suspect terranes.

\section{ACKNOWLEDGMENTS}

Mark Johnsson, Tom Brocculeri, Patrick McClung, Bill Arendt, and Lu Huafu assisted in the field. Financial support to the University of Missouri was generously supplied by ARCO Alaska, Inc. We thank G. Van Kooten and his ARCO colleagues for their scientific cooperation and logistical aid. Superintendent Don Chase granted permission to sample in the Yukon-Charley Rivers National Preserve. We thank Paul G. Spry of Iowa State University and Robert L. Bauer of the University of Missouri-Columbia for helpful reviews of this manuscript. Acknowledgment is also made to the Donors of the Petroleum Research Fund, administered by the American Chemical Society, for partial support of this research (grants
No. 22773-AC2 to Underwood and No. 25926-AC8 to Shelton).

\section{REFERENCES CITED}

Barker, C.E., 1988, Geothermics of petroleum systems: Implications of the stabilization of kerogen maturation after a geologically brief heating duration at peak temperature, in Magoon, L.B., ed., Petroleum systems of the United States: U.S. Geological Survey Bulletin 1870, p. 26-29.

Bebout, G.E., and Barton, M.D., 1989, Fluid flow and metasomatism in a subduction zone hydrothermal system: Catalina Schist terrane, California: Geology, v. 17, p. 976-980.

Brabb, E.E., and Churkin, Michael, Jr., 1969, Geologic map of the Charley River quadrangle, east-central Alaska: U.S. Geological Survey Miscellaneous Geologic Investigations Map I-973, scale 1: 250,000.

Burkhard, Martin, and Kerrich, Robert, 1988, Fluid regimes in the deformation of the Helvetic nappes, Switzerland, as inferred from stable isotope data: Contributions to Mineralogy and Petrology, v. 99, p. 416-429.

Churkin, M., Jr., Foster, H.L., Chapman, R.H., and Weber, F.R., 1982, Terranes and suture zones in east-central Alaska: Journal of Geophysical Research, v. 87, p. 3718-3730.

Clayton, R.N., and Mayeda, T.K., 1963, The use of bromine pentafluoride in the extraction of oxygen from oxides and silicates for isotopic analysis: Geochimica et Cosmochimica Acta, v. 27, p. $43-52$.

Clayton, R.N., O'Neil, J.R., and Mayeda, T.K., 1972, Oxygen isotope exchange between quartz and water: Journal of Geophysical Research, v. 77, p. 3057-3067.

Coney, P.J., and Jones, D.L., 1985, Accretion tectonics and crustal structure in Alaska: Tectonophysics, v. 119, p. 265-283.

Diamond, L.W., 1992, Stability of $\mathrm{CO}_{2}$ clathrate hydrate $+\mathrm{CO}_{2}$ liquid $+\mathrm{CO}_{2}$ vapour + aqueous $\mathrm{KCl}-\mathrm{NaCl}$ solutions: Experimental determination and application to salinity estimates of fluid inclusions: Geochimica et Cosmochimica Acta, v. 56, p. 273-280.

Dietrich, Dorothee, McKenzie, J.A., and Song, Hinglin, 1983, Origin of calcite in syntectonic veins as determined from carbonisotope ratios: Geology, v. 11, p. 547-551.

Dover, J.H., 1990, Geology of east-central Alaska: U.S. Geological Survey Open-File Report 90-289, 66 p.

Dover, J.H., and Miyaoka, R.T., 1988, Reinterpreted geologic map and fossil data, Charley River quadrangle, east-central Alaska: U.S. Geological Survey Miscellaneous Field Studies Map MF2004, 2 sheets, scale 1:250,000.

Emrich, K., Ehhalt, D.H., and Vogel, J.C., 1970, Carbon isotope fractionation during the precipitation of calcium carbonate: Earth and Planetary Science Letters, v. 8, p. 363-371.

Foster, H.L., 1976, Geologic map of the Eagle quadrangle, Alaska: U.S. Geological Survey Miscellaneous Geologic Investigations Map I-922, 1 sheet, scale 1:250,000.

Friedman, Irving, and O'Neil, J.R., 1977, Compilation of stable isotope fractionation factors of geochemical interest: U.S. Geological Survey Professional Paper 440-KK, p. 1-12.

Howell, D.G., Johnsson, M.J., Underwood, M.B., Lu Huafu, and Hillhouse, J.W., 1992, Tectonic evolution of the Kandik region, east-central Alaska: Preliminary interpretations, in Bradley, D.C. 
and Ford, A.B., eds., Geologic studies in Alaska by the U.S. Geological Survey During 1990: U.S. Geological Survey Bulletin 1999, p. 127-140.

Howell, D.G., and Wiley, T.J., 1987, Crustal evolution of northern Alaska inferred from sedimentological and structural relations in the Kandik area: Tectonics, v. 6, p. 619-631.

Hudson, J.D., 1977, Stable isotopes and limestone lithification: Journal of the Geological Society of London, v. 133, p. 637-660.

Jacobs, G.K., and Kerrick, D.M., 1981, Methane: An equation of state with application to the ternary system $\mathrm{H}_{2} \mathrm{O}-\mathrm{CO}_{2}-\mathrm{CH}_{4}$ : Geochimica et Cosmochimica Acta, v. 45, p. 607-614.

Keith, M.L., and Weber, J.N., 1964, Carbon and oxygen isotopic composition of selected limestones and fossils: Geochimica et Cosmochimica. Acta, v. 28, p. 1787-1816.

Laughland, M.M., Underwood, M.B., and Wiley, T.J., 1990, Thermal maturity, tectonostratigraphic terranes, and regional tectonic history: An example from the Kandik area, east-central Alaska, in Nuccio, V.F., and Barker, C.E., eds., Applications of thermal maturity studies to energy exploration: Society of Economic Paleontologists and Mineralogists, Rocky Mountain Section, Special Publication, p. 97-111.

Magaritz, Mordeckai, and Taylor, H.P., Jr., 1976, Oxygen, hydrogen and carbon isotope studies of the Franciscan formation, Coast Ranges, California: Geochimica et Cosmochimica Acta, v. 40, p. 215-234.

McCrea, J.M., 1950, The isotope chemistry of carbonates and a paleotemperature scale: Journal of Chemical Physics, v. 18, p. 849-857.

Miyaoka, R.T., 1990, Fossil locality map and fossil data for the southeastern Charley River quadrangle, east-central Alaska: U.S. Geological Survey Miscellaneous Field Studies Map MF-2007, 1 sheet, scale 1:63,360, $46 \mathrm{p}$.

Nesbitt, B.E., and Muehlenbachs, Klaus, 1989, Origin and movement of fluids during deformation and metamorphism in the Canadian Cordillera: Science, v. 245, p. 733-736.

O'Neil, J.R., 1986, Theoretical and experimental aspects of isotopic fractionation, in Valley, J.W., Taylor, H.P., Jr., and O'Neil, J.R., eds., Stable isotopes in high temperature geological processes: Reviews in Mineralogy, v. 16, p. 1-40.

O’Neil, J.R., Clayton, R.N., and Mayeda, T.K., 1969, Oxygen iso- tope fractionation in divalent metal carbonates: Journal of Chemical Physics, v. 51, p. 5547-5558.

Payne, M.W., and Allison, C.W., 1981, Paleozoic continental-margin sedimentation in east-central Alaska: Geology, v. 9, p. 274279.

Potter, R.W., II, 1977, Pressure corrections for fluid-inclusion homogenization temperatures based on the volumetric properties of the system NaCl- $\mathrm{H}_{2} \mathrm{O}$ : U. S. Geological Survey Journal of Research, v. 5, p. 603-607.

Potter, R.W., II, Clynne, M.A., and Brown, D.L., 1978, Freezing point depression of aqueous sodium chloride solutions: Economic Geology, v. 73, p. 284-285.

Ritger, Scott, Carson, Bobb, and Suess, Erwin, 1987, Methane-derived authigenic carbonates formed by subduction induced porewater expulsion along the Oregon/Washington margin: Geological Society of America Bulletin, v. 98, p. 147-156.

Roedder, Edwin, 1984, Fluid inclusions: Reviews in Mineralogy, v. $12,644 \mathrm{pp}$.

Rye, D.M., and Bradbury, H.J., 1988, Fluid flow in the crust: An example from a Pyrenean thrust ramp: American Journal of Science, v. 288, p. 197-235.

Shelton, K.L., Underwood, M.B., Bergfeld, Deborah, and Howell, D.G., 1992, Isotopic variations in calcite veins from the Kandik region of east-central Alaska: in Bradley, Dwight, and DuselBacon, Cynthia, eds., Geologic studies in Alaska by the U.S. Geological Survey 1991: U.S. Geological Survey Bulletin 2041, p. 213-221.

Sheppard, S.M.F., 1986, Characterization and isotopic variations in natural waters, in Valley, J.W., Taylor, H.P., Jr., and O'Neil, J.R., eds., Stable isotopes in high temperature geological processes: Reviews in Mineralogy, v. 16, p. 165-184.

Swanenberg, H.E.C., 1979, Phase equilibria in carbonic systems, and their application to freezing studies of fluid inclusions: Contributions to Mineralogy and Petrology, v. 68, p. 303-306.

Underwood, M.B., Laughland, M.M., Wiley, T.J., and Howell, D.G., 1989, Thermal maturity and organic geochemistry of the Kandik Basin region, east-central Alaska: U. S. Geological Survey Open-File Report 89-353, 41 p.

Underwood, M.B., Brocculeri, Thomas, Bergfeld, Deborah, Howell, D.G., and Pawlewicz, Michael, 1992, Statistical comparison between illite crystallinity and vitrinite reflectance, Kandik Region of east-central Alaska, in Bradley, Dwight, and DuselBacon, Cynthia, eds., Geologic studies in Alaska by the U.S. Geological Survey 1991: U.S. Geological Survey Bulletin 2041, p. 222-237.

Valley, J.W., 1986, Stable isotope geochemistry of metamorphic rocks, in Valley, J.W., Taylor, H.P., Jr., and O’Neil, J.R., eds., Stable isotopes in high temperature geological processes: Reviews in Mineralogy, v. 16, p. 445-490.

Wickham, S.M., and Taylor, H.P., Jr., 1987, Stable isotope constraints on the origin and depth of penetration of hydrothermal fluids associated with Hercynian regional metamorphism and crustal anatexis in the Pyrenees: Contributions to Mineralogy and Petrology, v. 95, p. 255-268. 


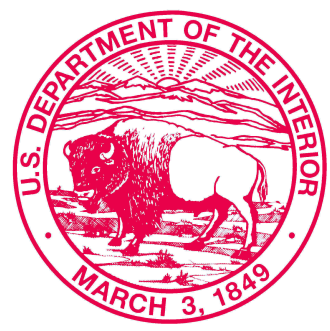

\section{Reference Publication}

Johnsson, M. J., and Howell, D.G., eds., 1996, Thermal evolution of sedimentary basins in Alaska: U.S. Geological Survey Bulletin 2142, 131 p. 